UNIVERSIDADE DE SÃO PAULO - USP

FACULDADE DE ECONOMIA, ADMINISTRAÇÃO E CONTABILIDADE DEPARTAMENTO DE ADMINISTRAÇÃO PROGRAMA DE PÓS-GRADUAÇÃO EM ADMINISTRAÇÃO

A IDENTIDADE SOCIAL: ESTUDO DAS RELAÇÕES DE CONSUMO E PRODUÇÃO DENTRO DO TRABALHO BANCÁRIO

Henrique Maia Veloso

Orientadora: Profa. Dra. Ana Cristina Limongi França

SÃO PAULO

2008 
Profa. Dra. Suely Vilela

Reitora da Universidade de São Paulo

Prof. Dr. Carlos Roberto Azzoni

Diretor da Faculdade de Economia, Administração e Contabilidade

Prof. Dr. Isak Kruglianskas

Chefe do Departamento de Administração

Prof. Dr. Lindolfo Galvão de Albuquerque

Coordenador do Programa de Pós-graduação em Administração 


\title{
A IDENTIDADE SOCIAL: ESTUDO DAS RELAÇÕES DE CONSUMO E PRODUÇÃO DENTRO DO TRABALHO BANCÁRIO
}

\author{
Tese apresentada ao Departamento de \\ Administração da Faculdade de Economia, \\ Administração e Contabilidade da \\ Universidade de São Paulo como requisito \\ para a obtenção do título de Doutor em \\ Administração.
}

Orientadora: Profa. Dra. Ana Cristina Limongi França 
FICHA CATALOGRÁFICA

Elaborada pela Seção de Processamento Técnico do SBD/FEA/USP

\section{Veloso, Henrique Maia}

A identidade social: estudo das relações de consumo e produção dentro do trabalho bancário / Henrique Maia Veloso. -- São Paulo, 2008.

$237 \mathrm{p}$.

Tese (Doutorado) - Universidade de São Paulo, 2008

Bibliografia.

1. Identidade social 2. Relações de trabalho 3. Consumo I. Universidade de São Paulo. Faculdade de Economia, Administração e Contabilidade II. Título.

CDD - 305 
Dedico este trabalho aos meus amores:

Tatiana, minha esposa, e Ana Luísa, minha filha. 


\section{AGRADECIMENTOS}

Este trabalho é fruto de uma trajetória intelectual que foi sendo consolidada na vivência e convivência com pessoas, espaços e instituições a quem devo o meu apreço e singelo agradecimento.

Minha orientadora, Profa. Dra. Ana Cristina Limongi França, foi alguém que soube me indicar os caminhos, preservando a minha Identidade e minhas opções. As escolhas que fizemos juntos mostram sintonias entre nossas visões ao longo deste trabalho. Agradeço sua atenção e compreensão não só pelos meus problemas de natureza acadêmica, mas pelas diversas questões que atravessaram minha vida pessoal durante este doutoramento.

Às professoras Dra. Solange Maria Pimenta e Dra. Maria Laetitia Corrêa, amigas, companheiras, que acompanharam grande parte da construção deste trabalho, indicando literaturas pertinentes ao desenvolvimento da pesquisa, deixando sempre tudo mais complexo, difícil e desafiador.

Aos professores Dr. André Luiz Fischer e Dra. Maria José Tonelli, membros da banca de qualificação, cujas leituras atentas ao meu trabalho foram responsáveis pela incorporação de elementos cruciais para a conclusão desta tese.

Não posso me esquecer do Prof. Dr. Lúcio Flávio Renault de Moraes e da Profa. Dra. Zélia Miranda Kilimnik que me iniciaram no universo acadêmico, no início de minha carreira docente e como pesquisador.

Minha gratidão aos professores da USP, Dr. Lindolfo Albuquerque Galvão, Dr. Roberto Coda, Dra. Maria Teresa Leme Fleury, Dra. Maria Rosa Fischer, Dr. Silvio Aparecido dos Santos e Dr. Adalberto Fischmann, que compartilharam conhecimentos e reflexões teóricas ao longo das disciplinas que ministraram e que, de alguma forma, estão presentes neste trabalho.

Meus queridos colegas de trabalho, sobretudo amigos cordiais, que não me deixaram descansar enquanto não terminasse esta tese, discutindo temáticas, indicando autores, criticando minhas visões simplistas e acrescentando variáveis. Algumas vezes, o simples "não desanime" foi fundamental. Obrigado Prof. José Milton Garcia, Profa. Maria Eliane Catunda 
de Siqueira, Profa. Dra. Marília de Gonzaga Lima e Silva Tose, Prof. Dr. Francisco Rogério de Oliveira Bonatto, Prof. Francisco de Paula Oliveira, Prof. Dr. Ronny Francy Campos, Profa. Maria José Scassiotti Souza, Profa. Dra. Moema Miranda de Siqueira, Prof. Dr. Tommy Akira Gotto, Prof. Sibélius Cefas Pereira, Profa. Maria Emília Almeida Cruz, Prof. Clodoaldo Coutinho Piragibe da Fonseca, Profa. Dra.Cristiane Fonseca Freitas, Dr. Cléber Alencar Salles, Prof. Dr. Sílvio César Moral Marques e Prof. Dr. Cláudio Correa.

Aos bancários que participaram desta pesquisa, anônimos, extremamente disponíveis e cordiais, cedendo parte de seu tempo para que esta tese pudesse se concretizar. Espero ter feito jus à contribuição que deram. Que este trabalho possa se refletir e retornar a todos vocês com melhorias futuras. Em especial, agradeço aos bancários Francisco e Antônio Carlos que não mediram esforços para abrir espaço entre os demais.

Agradeço aos colegas de Doutorado que também são parte desta pequena brevidade temporal: Profa. Sônia Regina Hierno Parolin, Profa. Amyra Moisés Sarsur, Prof. Marcos Abílio Bosquetti, Prof. Luciano Sathler Rosa Guimarães, Prof. Sérgio Silva Dantas, Prof. Wilson Amorin, Profa. Angeli Kishore, Prof. Silvio Roberto Stefano, Profa. Renata Schirrmeister, Profa. Tatiana de Almeida Proença, Prof. Reinaldo Koei Yonamine, Prof. César Martins Guimarães, Prof. Flávio Lício, Profa. Ângela Christina Lucas, Profa. Annelise Vendramini, Prof. Solemar Merino Jorge, Prof. Hermann Hrdlicka, Prof. Victor Richarte Martinez, Prof. Leonardo José Schettino Peixoto, Profa. Neila Conceição Viana da Cunha, Prof. Francisco Ribeiro de Almeida, Prof. Márcio Shoiti Kuniyoshi, Profa. Carolina Harumi Koshima Beker, Prof. Armando Lourenzo Moreira Júnior, Profa. Daniela Motta Romeiro Khauaja e tantos outros com quem tive o prazer de conviver. Peço desculpas caso tenha me esquecido de alguém, mas saibam todos que foram importantes para mim.

À Universidade de São Paulo, que, na figura de seus funcionários, acolheu-me assim como acolhe a uma diversidade enorme de pesquisadores e estudiosos oriundos de diversas regiões, mostrando a plenitude da inclusão e diversidade cultural. Dentro da grandiosidade que é essa Universidade, fico feliz em ser parte de sua história. Em especial, agradeço aos vigilantes que me deram suporte num momento complicado que vivenciei na USP e aos funcionários das secretarias da pós-graduação. 
Minha esposa, minha filha, meus pais, meus irmãos. Para minha família, poucas palavras: eterna gratidão pelo intenso e incomensurável apoio.

Por último, mas não menos importante, digo que este trabalho não seria realizado se a Universidade onde trabalho não me desse o apoio e crédito, não apenas com palavras de incentivo, mas com um efetivo suporte institucional. Por isso agradeço à PUC Minas que, por meio do seu Programa Permanente de Capacitação Docente, confiou e investiu nesta obra e nesse processo de crescimento profissional. 
Nada resiste à realidade, embora, às vezes, a realidade a nada resiste. 


\section{RESUMO}

Esta tese teve como objetivo analisar como as Identidades Sociais dos bancários têm sido afetadas pelas transformações do mundo do trabalho e pelos valores da sociedade do consumo. As Identidades Sociais são consideradas como importantes referenciais para entender a dinâmica dentro das organizações. Há uma corrente de pensadores que descrevem o trabalho perdendo sua relativa importância como referência social em função das metamorfoses que vem sofrendo. Por outro lado, autores descrevem que os valores da sociedade do consumo estão se revigorando no atual contexto, servindo, cada vez mais, como parâmetros para os sujeitos. $\mathrm{Na}$ medida em que as Identidades Sociais são afetadas pelos valores que permeiam determinado contexto social, procurou-se entender como tais mudanças estão afetando o constructo. Partindo de uma visão construcionista, estabeleceu-se uma abordagem qualitativa para estudar como 50 bancários, por meio de seus discursos, reconstruíam suas Identidades Sociais e as ligações dessas com o trabalho e o consumo. Os dados foram tratados por meio de análise de conteúdo, sendo que também foi realizado um focus group com bancários, discutindo os resultados da pesquisa. Como conclusões obteve-se que os elementos do trabalho ainda são fonte de referência para as Identidades Sociais. Os elementos do consumo também apareceram como parâmetros importantes no discurso. $\mathrm{O}$ consumo e o trabalho se mostram como referências complementares, embora sejam provenientes de situações e relações antagônicas. 


\begin{abstract}
This thesis aimed to analyze how the bank workers Social Identities have been affected by the changes in the global work order and by the values of the current consumption society. The Social identities are considered important references to comprehend the dynamics inside the organizations. There is a group of researchers that describes the work activity failing to maintain its relative importance as a social reference due to the metamorphosis it has been experiencing. On the other hand, the authors assure that the consumption society values are gathering new strength in the present context, and are offering new patterns to the individuals. As the Social Identities are affected by the values that permeate a specific social context, we tried to understand how such changes are affecting the constructus. We started from a constructionist conception and we established a qualitative approach to study how the 50 bank workers unveil through their discourses the ways they reconstruct their Social Identities in relation to work and consumption. The data were treated by means of an analysis upon the content, and we also carried out a focus group with the bank workers, in which we discussed the results of the research. We reached the conclusion that the constituents of the work are yet a strong reference to the Social Identities. The consumption elements also appear as important patterns in the discourse. The consumption and the work are revealed as references, although they derive from antagonistic situations and relationships.
\end{abstract}




\section{SUMÁRIO}

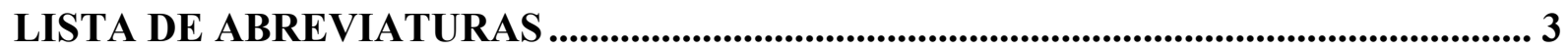

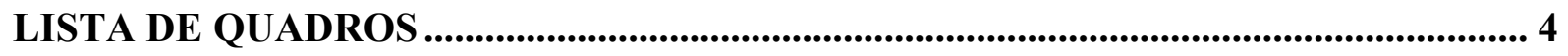

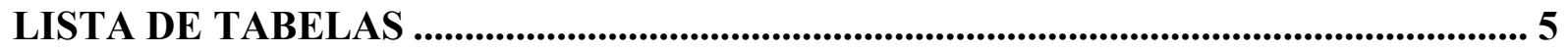

LISTA DE ILUSTRAÇÕES ............................................................................................... 9

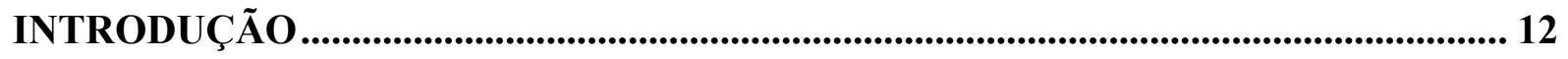

CAPÍTULO 1 - O PROBLEMA DE PESQUISA ........................................................... 16

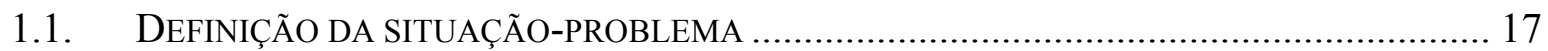

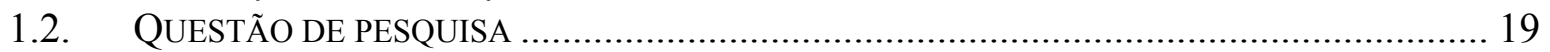

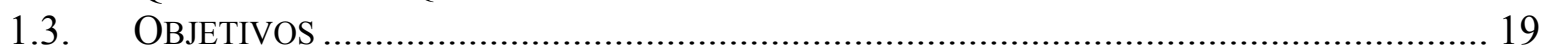

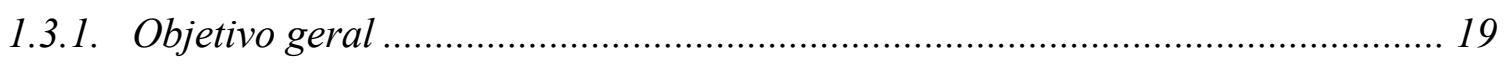

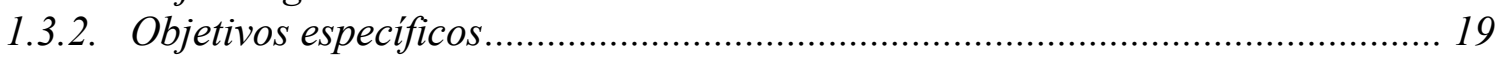

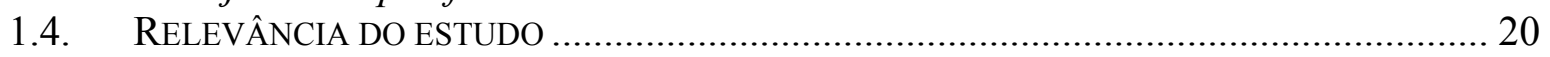

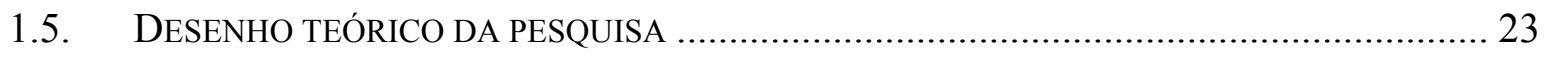

CAPÍTULO 2 - FUNDAMENTAÇÃO TEÓRICA DA PESQUISA .................................. 24

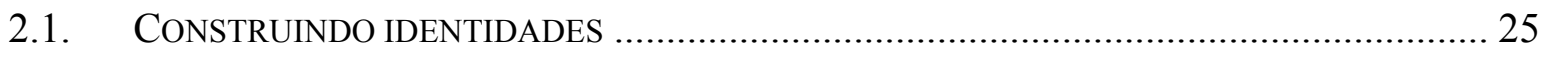

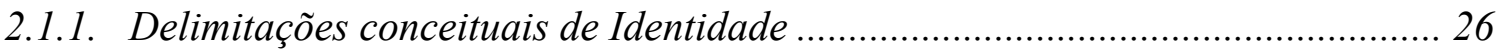

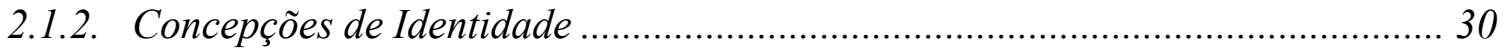

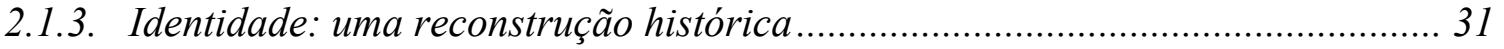

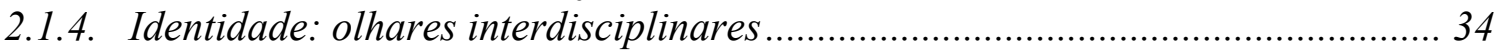

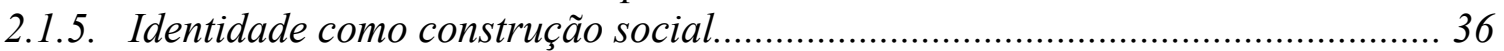

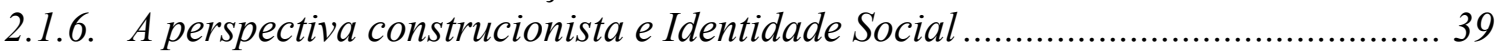

2.1.7. Identidade Social dentro do espaço organizacional............................................. 41

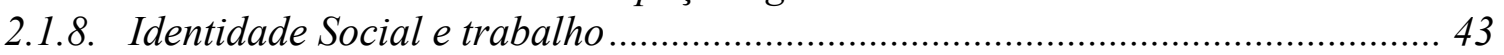

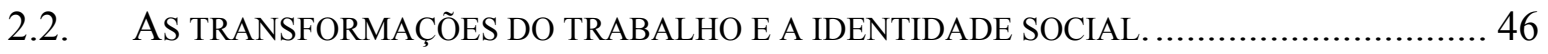

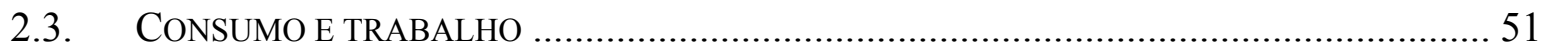

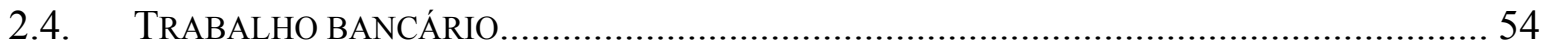

2.4.1. Questões contextuais e as instituições do sistema financeiro.............................. 55

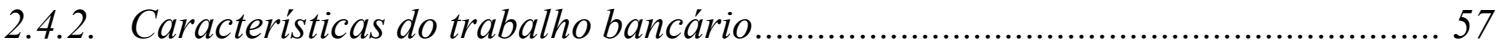

2.4.3. Alterações no setor bancário no Brasil ............................................................. 58

CAPÍTULO 3 - ASPECTOS METODOLÓGICOS DA PESQUISA............................... 68

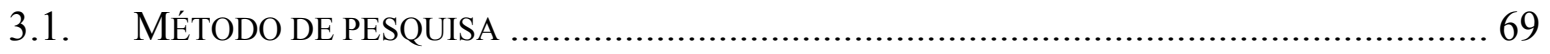

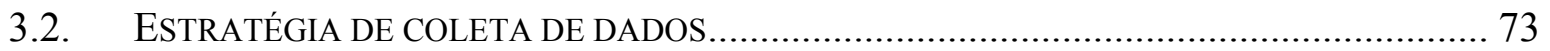

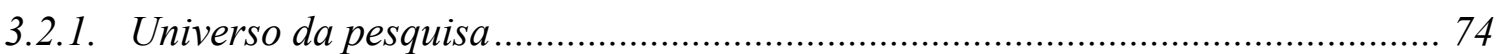

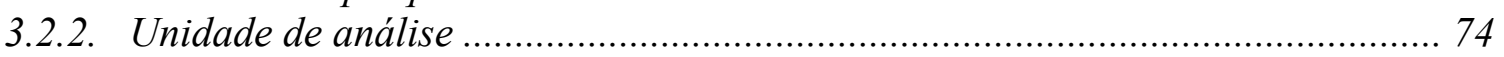

3.2.3. Operacionalização do conceito de Identidade ....................................................... 74

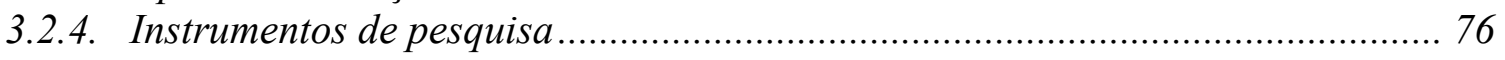

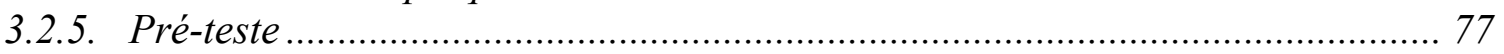

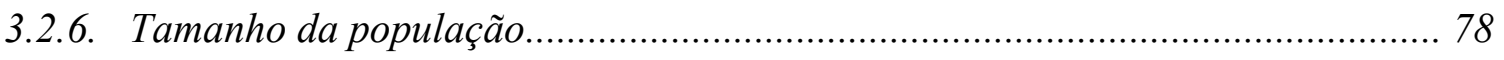

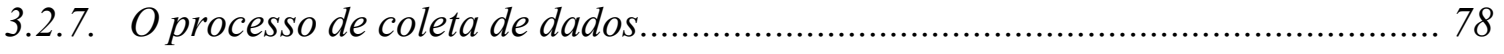

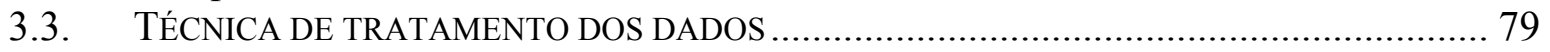

3.3.1. Desenho da estratégia de coleta e tratamento de dados .................................. 81

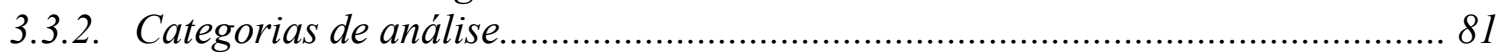

3.4. DESCRIÇÃO GERAL DA POPULAÇÃO ENTREVISTADA.................................................. 83 


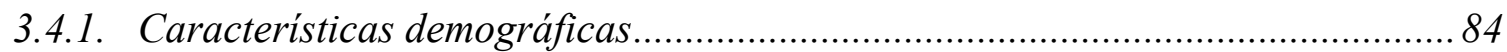

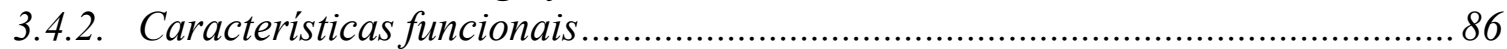

3.4.3. Dados das organizações às quais os entrevistados fazem parte ......................... 89

CAPÍTULO 4 - RESULTADOS DA PESQUISA ................................................................94

4.1. VISÃO SOBRE AS TRANSFORMAÇÕES DO CONTEXTO …........................................... 95

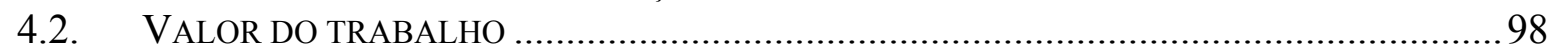

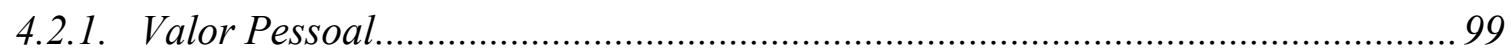

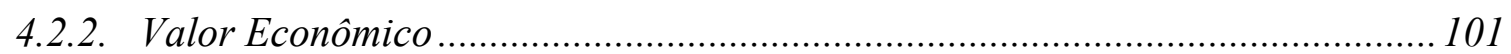

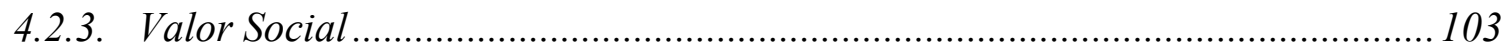

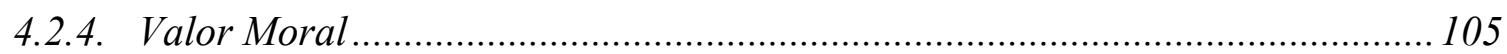

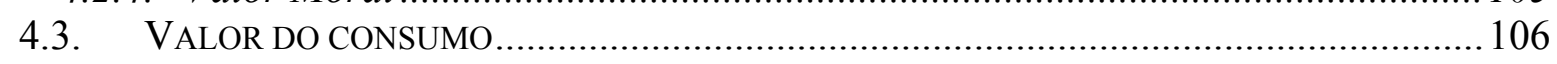

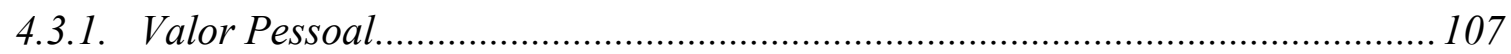

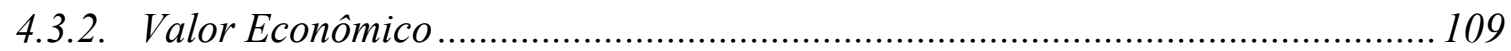

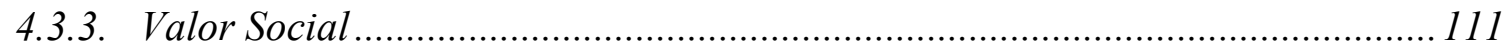

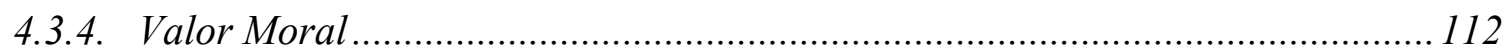

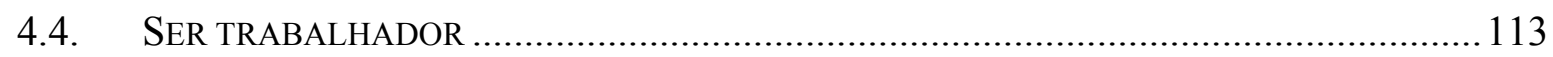

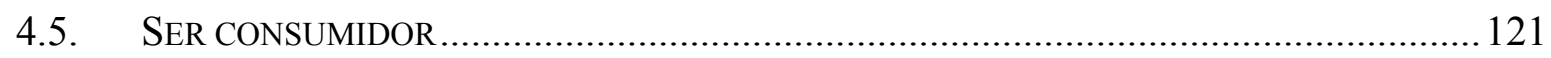

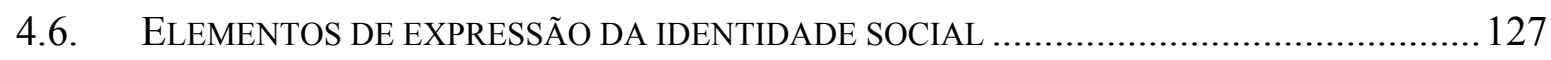

4.6.1. Expressão da Identidade, identificação e trabalho ............................................ 129

4.6.2. Expressão da Identidade, identificação e categoria profissional ........................ 131

4.6.3. Expressão da Identidade, identificação e organização...................................... 133

4.6.4. Expressão da Identidade, identificação e consumo............................................. 138

4.6.5. Expressão da Identidade, identificação e consumidor ....................................... 143

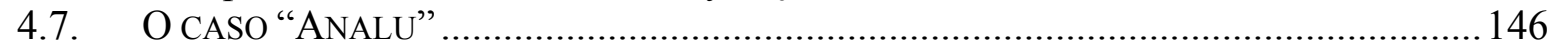

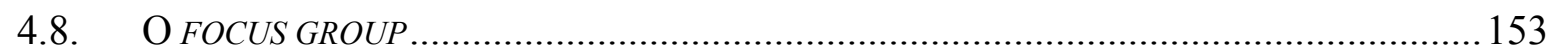

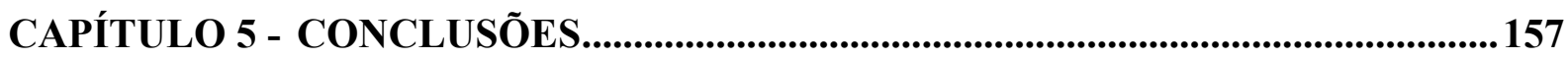

CAPÍTULO 6 - (IN)CONCLUSÕES E RECOMENDAÇÕES ....................................162

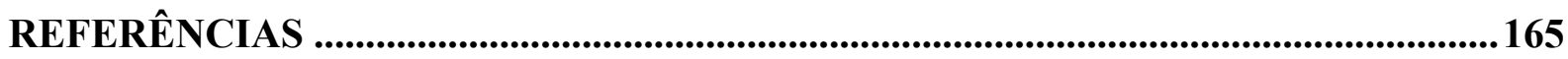

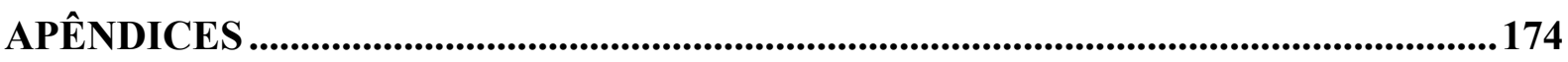

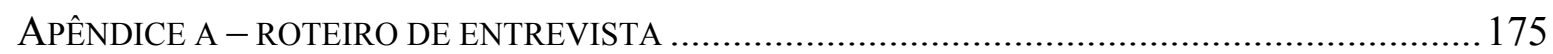

APÊNDICE B - QUADROS DE ANÁLISE DO ROTEIRO DE ENTREVISTA.................................... 179

APÊNDICE C - ANÁLISE DOS DADOS INDIVIDUAIS DOS ENTREVISTADOS ............................... 180

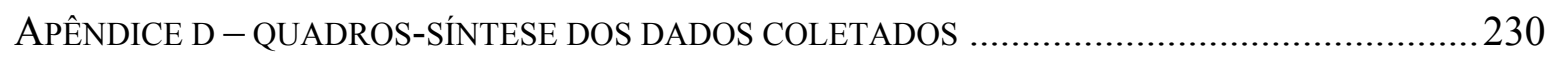

ÍNDICE REMISSIVO DAS FALAS DOS ENTREVISTADOS ...................................... 235 


\section{LISTA DE ABREVIATURAS}

BCB: Banco Central do Brasil

BACEN: Banco Central do Brasil

DIEESE: Departamento Intersindical de Estatística e Estudos Socioeconômicos

FEBRABAN: Federação Brasileira de Bancos

PAB: Posto Avançado Bancário

PROCON: Procuradoria do Consumidor 


\section{LISTA DE QUADROS}

Quadro 1 - Número de fusões, aquisições e incorporações por ano no setor bancário do Brasil entre Julho de 1995 e Outubro de 2006 .............................................................60

Quadro 2 - Número estimado de empregados nos bancos no Brasil entre 1989 e 1996 .......60

Quadro 3 - Máquinas de auto-atendimento para saque e depósito no setor bancário do Brasil

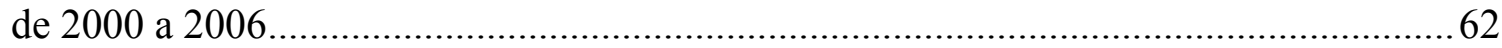

Quadro 4 - Descritores do planejamento desta pesquisa segundo quadro elaborado por

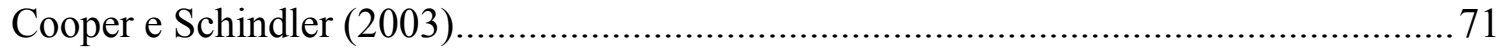

Quadro 5 - Quadro de análise das respostas dos bancários para a categoria "Ser Trabalhador"

Quadro 6 - Quadro de análise das referências encontradas para descrever o "Ser Trabalhador".

Quadro 7 - Quadro de análise das respostas dos bancários para a categoria "Ser Trabalhador"

Quadro 8 - Quadro de análise da expressão da Identidade associada ao trabalho. 130

Quadro 9 - Quadro de análise da expressão da Identidade associada à categoria profisssional..

Quadro 10 - Quadro de análise da expressão da Identidade associada à organização 136

Quadro 11 - Quadro de análise da expressão da Identidade associada ao consumo 143

Quadro 12 - Como o Entrevistado 15 descreve o "eu" e o "outro" nas situações de trabalho e de consumo.

Quadro 13 - Quadro de análise do roteiro de pesquisa por categoria de análise 179

Quadro 14 - Quadro resumo das características demográficas dos entrevistados 231

Quadro 15 - Quadro resumo das características funcionais dos entrevistados. 233 


\section{LISTA DE TABELAS}

Tabela 1 - Número de transações realizadas no setor bancário no Brasil em 2006.

Tabela 2 - Distribuição dos respondentes da pesquisa por gênero - dados coletados nas

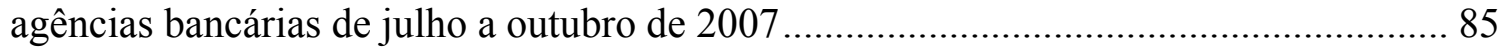

Tabela 3 - Distribuição dos respondentes da pesquisa por idade - dados coletados nas

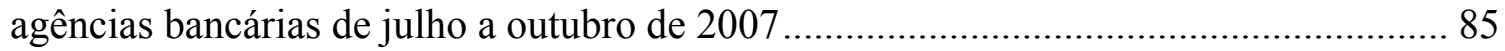

Tabela 4 - Distribuição dos respondentes da pesquisa por grau de instrução formal - dados coletados nas agências bancárias de julho a outubro de 2007 ...................................... 85

Tabela 5 - Distribuição dos respondentes da pesquisa por estado civil - dados coletados nas agências bancárias de julho a outubro de 2007

Tabela 6 - Distribuição dos respondentes da pesquisa por nível hierárquico do cargo ocupado - dados coletados nas agências bancárias de julho a outubro de 2007 .............. 86

Tabela 7 - Distribuição dos respondentes por tempo no atual cargo - dados coletados nas agências bancárias de julho a outubro de 2007

Tabela 8 - Distribuição dos respondentes por tempo na atual instituição - dados coletados nas agências bancárias de julho a outubro de 2007

Tabela 9 - Distribuição dos respondentes por tempo na atual agência - dados coletados nas agências bancárias de julho a outubro de 2007

Tabela 10 - Distribuição dos respondentes da pesquisa por resposta à pergunta "Trabalhou em outros bancos?" - dados coletados nas agências bancárias de julho a outubro de 2007

Tabela 11 - Distribuição dos respondentes por tempo total como bancário - dados coletados nas agências bancárias de julho a outubro de 2007 88

Tabela 12 - Distribuição dos respondentes da pesquisa por resposta à pergunta "Na execução do trabalho, tem contato com cliente?" - dados coletados nas agências bancárias de julho a outubro de 2007 .

Tabela 13 - Distribuição dos respondentes da pesquisa por resposta à pergunta "Na execução do trabalho, tem contato com outros funcionários?" - dados coletados nas agências bancárias de julho a outubro de 2007.

Tabela 14 - Distribuição dos bancos no Brasil segundo a natureza econômica da instituição em Fevereiro de 2008.

Tabela 15 - Distribuição dos bancos em número de agências no Brasil segundo a natureza econômica da instituição em Fevereiro de 2008.

Tabela 16 - Distribuição dos bancos em número de postos avançados bancários no Brasil segundo a natureza econômica da instituição em Fevereiro de 2008. 
Tabela 17 - Distribuição dos respondentes da pesquisa por natureza econômica das instituições em que trabalham atualmente - dados coletados nas agências bancárias de julho a outubro de 2007

Tabela 18 - Distribuição dos bancos no Brasil segundo a nacionalidade da propriedade da instituição em Fevereiro de 2008

Tabela 19 - Distribuição dos bancos em quantidade de agências e postos avançados bancários no Brasil segundo a nacionalidade da propriedade da instituição em Fevereiro de 2008 ....

Tabela 20 - Distribuição dos entrevistados segundo a nacionalidade da propriedade do banco em Fevereiro de 2008

Tabela 21 - Distribuição dos respondentes da pesquisa por resposta à pergunta "Como você vê a profissão de bancário no passado?"- dados coletados nas agências bancárias de julho a outubro de 2007

Tabela 22 - Distribuição dos respondentes da pesquisa por resposta à pergunta "Como você vê a profissão de bancário no presente?"- dados coletados nas agências bancárias de julho a outubro de 2007

Tabela 23 - Distribuição dos respondentes da pesquisa por resposta à pergunta "Como você vê a profissão de bancário no futuro?"- dados coletados nas agências bancárias de julho a outubro de 2007

Tabela 24 - Distribuição dos respondentes da pesquisa por categorização do trabalho como Valor Pessoal em seus discursos - dados coletados nas agências bancárias de julho a outubro de 2007

Tabela 25 - Distribuição dos respondentes da pesquisa por categorização do trabalho como Valor Econômico em seus discursos - dados coletados nas agências bancárias de julho a outubro de 2007

Tabela 26 - Distribuição dos respondentes da pesquisa por categorização do trabalho como Valor Social em seus discursos - dados coletados nas agências bancárias de julho a outubro de 2007

Tabela 27 - Distribuição dos respondentes da pesquisa por categorização do trabalho como Valor Moral em seus discursos - dados coletados nas agências bancárias de julho a outubro de 2007.

Tabela 28 - Distribuição dos respondentes da pesquisa por categorização do consumo como Valor Pessoal em seus discursos - dados coletados nas agências bancárias de julho a outubro de 2007

Tabela 29 - Distribuição dos respondentes da pesquisa por categorização do consumo como Valor Econômico em seus discursos - dados coletados nas agências bancárias de julho a outubro de 2007 109

Tabela 30 - Distribuição dos respondentes da pesquisa por categorização do consumo como 
Valor Social em seus discursos - dados coletados nas agências bancárias de julho a outubro de 2007

Tabela 31 - Distribuição dos respondentes da pesquisa por categorização do consumo como Valor Moral em seus discursos - dados coletados nas agências bancárias de julho a outubro de 2007 112

Tabela 32 - Quantidade de respondentes por tipo de citação na categoria de análise "Ser Trabalhador" - dados coletados nas agências bancárias de julho a outubro de 2007 ... 116

Tabela 33 - Quantidade de respondentes por tipo de citação na categoria de análise "Ser Consumidor" - dados coletados nas agências bancárias de julho a outubro de 2007 .... 124

Tabela 34 - Distribuição dos respondentes da pesquisa por resposta à pergunta "Quando as pessoas perguntam quem é você, o que utiliza como referência para explicar quem é?" dados coletados nas agências bancárias de julho a outubro de 2007

Tabela 35 - Distribuição dos respondentes da pesquisa por resposta à pergunta "O que você diz para seu filho sobre quem você é e o que você faz?" - dados coletados nas agências bancárias de julho a outubro de 2007.

Tabela 36 - Distribuição dos respondentes da pesquisa por "Referências mais citadas nas questões de Identidade" - dados coletados nas agências bancárias de julho a outubro de 2007

Tabela 37 - Distribuição dos respondentes da pesquisa por resposta à pergunta "Você se identifica com seu trabalho?" - dados coletados nas agências bancárias de julho a outubro de 2007

Tabela 38 - Distribuição dos respondentes da pesquisa por resposta à pergunta "Você acha que o trabalho afeta na definição de quem é você?"- dados coletados nas agências bancárias de julho a outubro de 2007. 130

Tabela 39 - Distribuição dos respondentes da pesquisa por resposta à pergunta "O que gostaria de mudar em seu trabalho?"- dados coletados nas agências bancárias de julho a outubro de 2007 131

Tabela 40 - Distribuição dos respondentes da pesquisa por resposta à pergunta "Você se identifica com a categoria profissional dos bancários?"- dados coletados nas agências bancárias de julho a outubro de $2007 .$.

Tabela 41 - Distribuição dos respondentes da pesquisa por resposta à pergunta "Você se sente bancário?" - dados coletados nas agências bancárias de julho a outubro de 2007

Tabela 42 - Distribuição dos respondentes da pesquisa por resposta à pergunta "Entre trabalhar como bancário em outra organização (diferente da que trabalha atualmente) e trabalhar no banco em outra profissão (não sendo bancário), em qual situação você se identifica mais?”- dados coletados nas agências bancárias de julho a outubro de 2007. 
Tabela 43 - Distribuição dos respondentes da pesquisa por resposta à pergunta "O banco afeta na definição de quem você é?" - dados coletados nas agências bancárias de julho a outubro de 2007 136

Tabela 44 - Distribuição dos respondentes da pesquisa por resposta à pergunta "Com quais aspectos da organização você se identifica?"- dados coletados nas agências bancárias de julho a outubro de 2007 136

Tabela 45 - Distribuição dos respondentes da pesquisa por resposta à pergunta "Qual é a importância que a organização tem na sua vida?"- dados coletados nas agências bancárias de julho a outubro de 2007

Tabela 46 Distribuição dos respondentes da pesquisa por resposta à pergunta "Gosta de fazer compras?" - dados coletados nas agências bancárias de julho a outubro de 2007

Tabela 47 Distribuição dos respondentes da pesquisa por como se definem na forma como consomem - dados coletados nas agências bancárias de julho a outubro de 2007

Tabela 48 Distribuição dos respondentes da pesquisa por resposta à pergunta "Você acha que ao consumir consegue expressar a sua individualidade, mostrando um quem é a partir do que consome e da forma que consome?" - dados coletados nas agências bancárias de julho a outubro de 2007

Tabela 49 Distribuição dos respondentes da pesquisa por resposta à pergunta "Você acha que o consumo afeta na definição de quem é você?"- dados coletados nas agências bancárias de julho a outubro de 2007 .

Tabela 50 - Distribuição dos respondentes da pesquisa por resposta à pergunta "Você acha que o consumidor afeta na definição de quem é você?"- dados coletados nas agências bancárias de julho a outubro de 2007

Tabela 51 - Distribuição dos respondentes da pesquisa por resposta à pergunta "Você prefere ser consumidor ou ser bancário?"- dados coletados nas agências bancárias de julho a outubro de 2007

Tabela 52 - Distribuição dos respondentes da pesquisa por resposta à pergunta "O consumidor é mais importante que o bancário?”- dados coletados nas agências bancárias de julho a outubro de 2007 .

Tabela 53 - Distribuição dos respondentes da pesquisa por resposta à pergunta "Qual é a importância do consumidor?"- dados coletados nas agências bancárias de julho a outubro de 2007 


\section{LISTA DE ILUSTRAÇÕES}

\section{GRÁFICO}

Gráfico 1 - Lucro líquido dos 11 maiores bancos no Brasil entre os anos 1994 e 2006. 66

\section{FIGURAS}

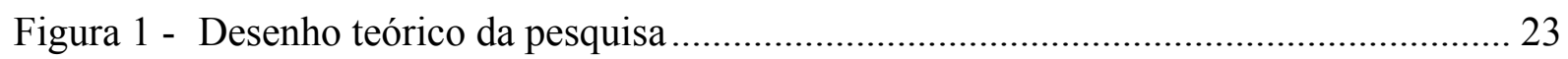

Figura 2 - As concepções de self e Identidade segundo Gustavsson (2005) .......................... 31

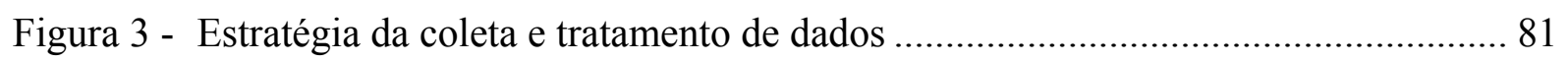

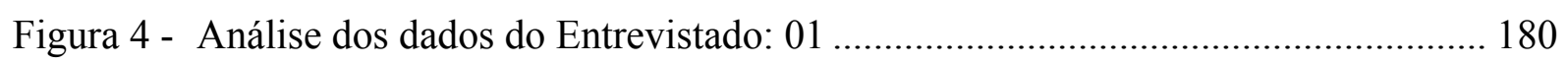

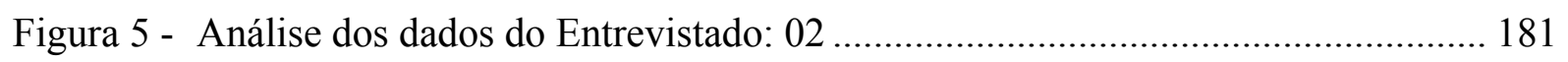

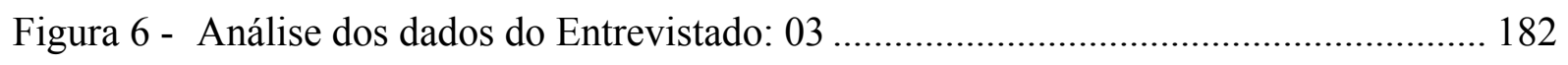

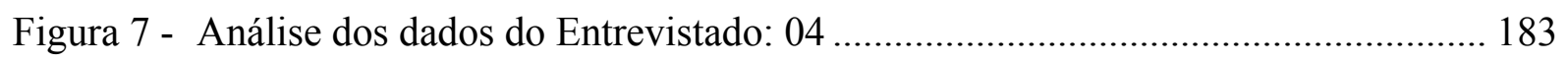

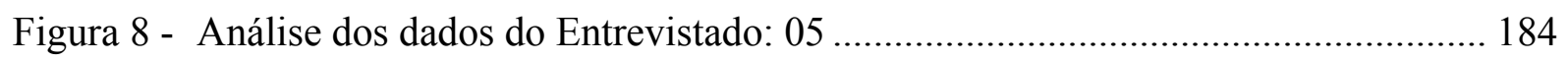

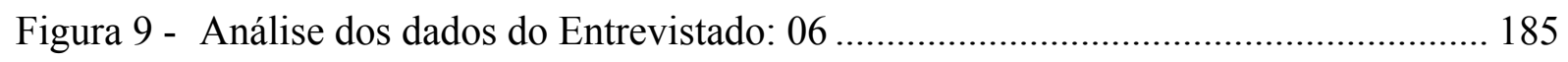

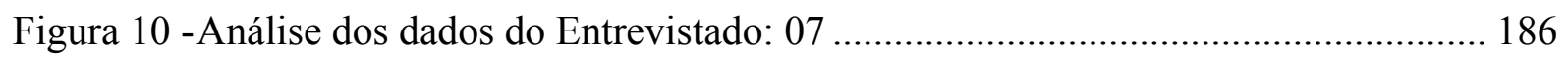

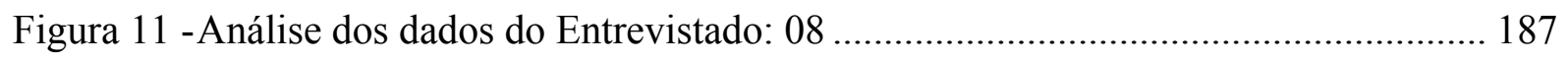

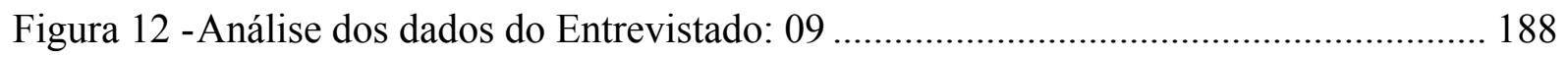

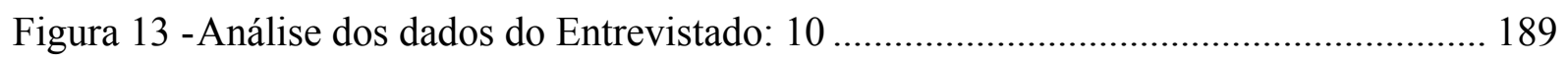

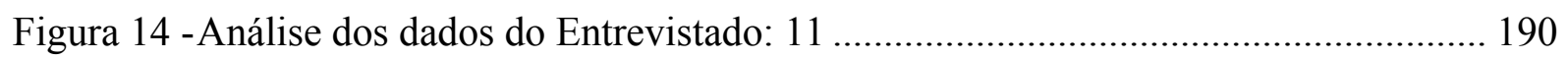

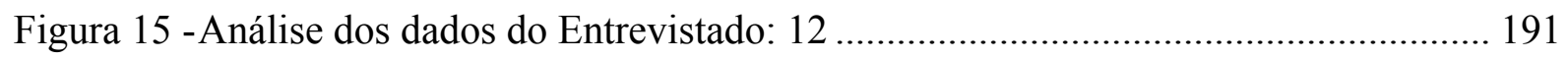

Figura 16 -Análise dos dados do Entrevistado: 13 ........................................................ 192

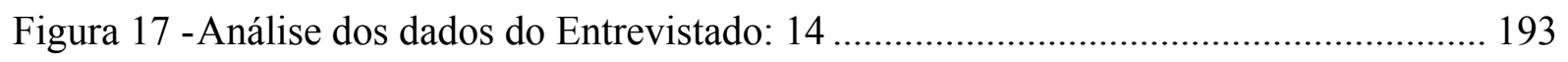

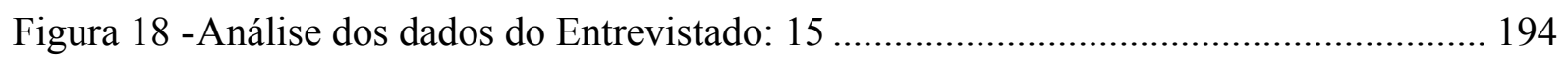

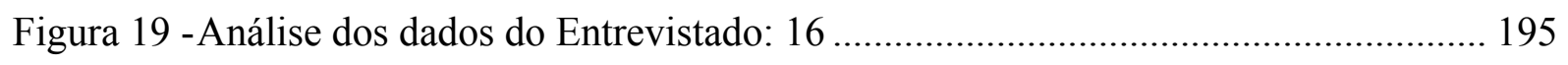

Figura 20 -Análise dos dados do Entrevistado: 17 ......................................................... 196

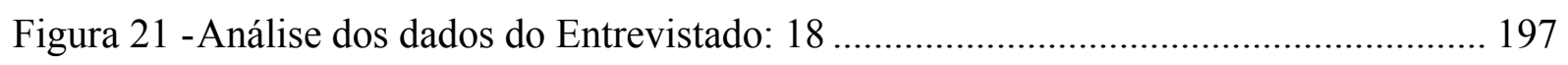

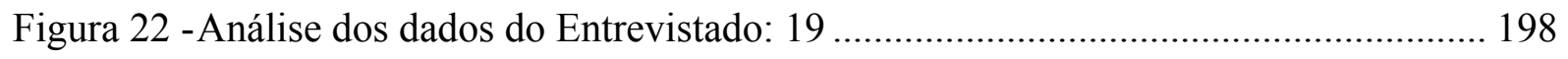


Figura 23 -Análise dos dados do Entrevistado: 20.

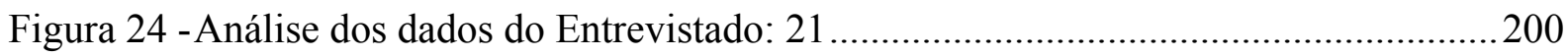

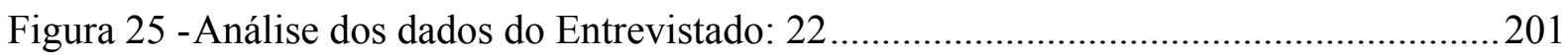

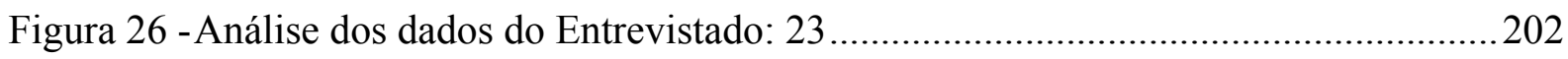

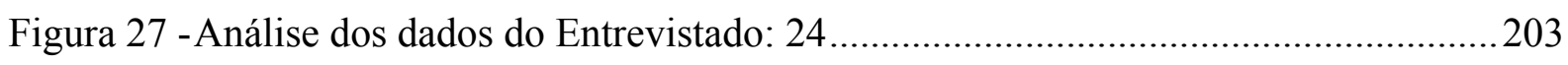

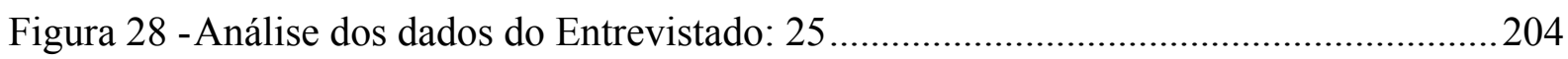

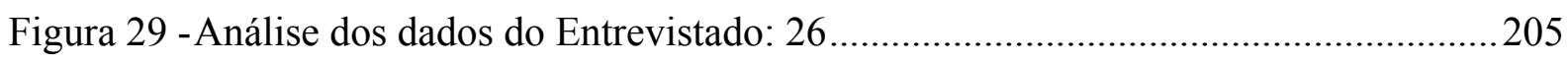

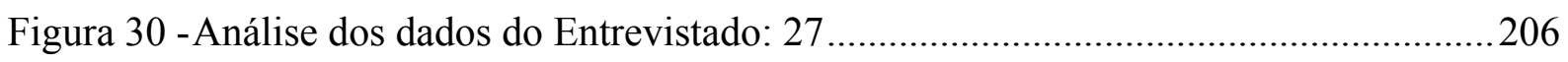

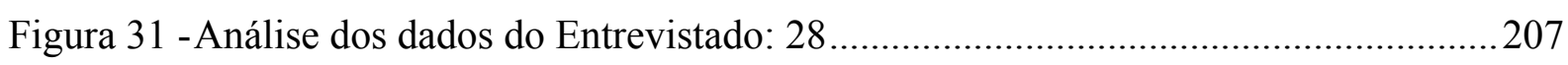

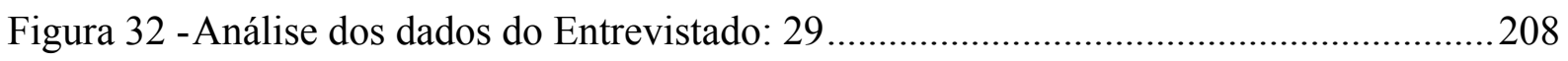

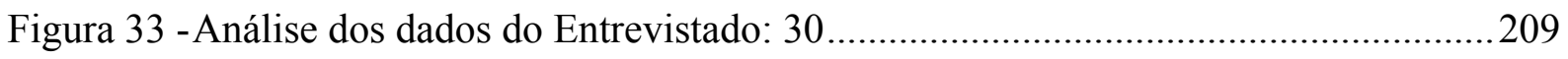

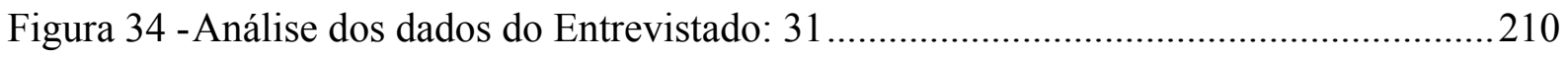

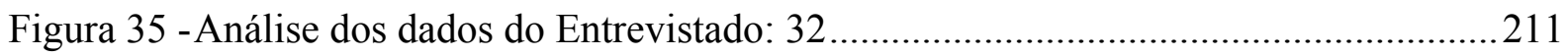

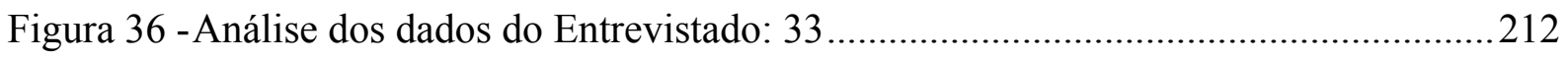

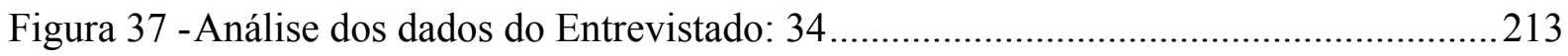

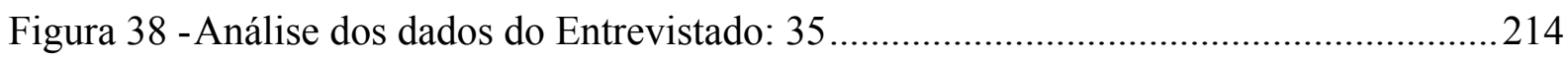

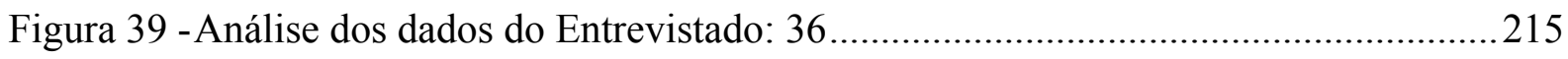

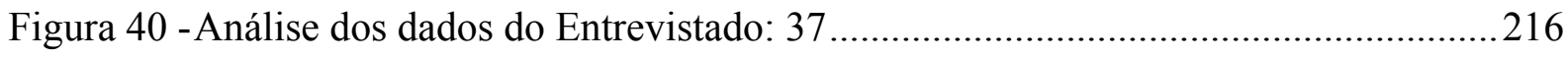

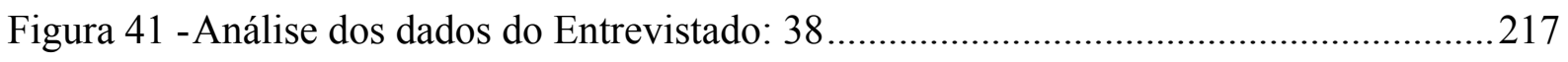

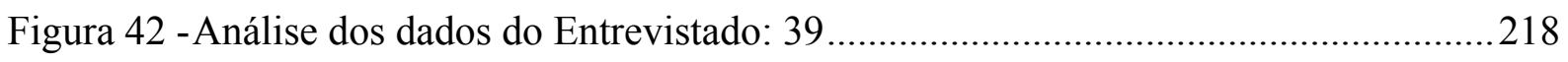

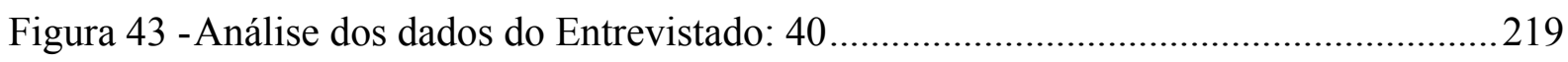

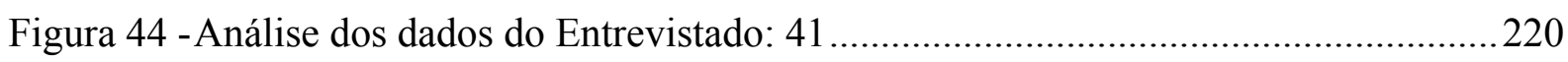

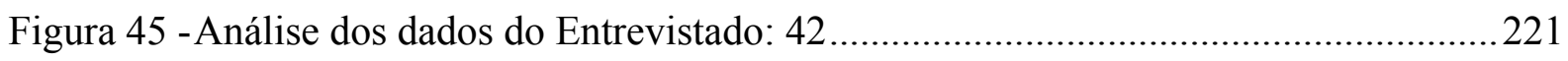

Figura 46 -Análise dos dados do Entrevistado: 43 ...........................................................222

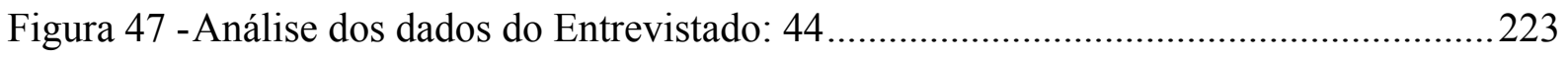

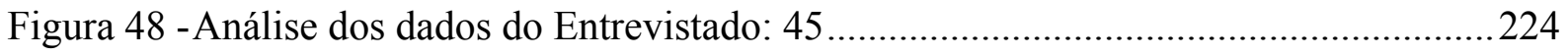

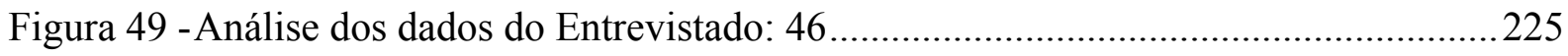




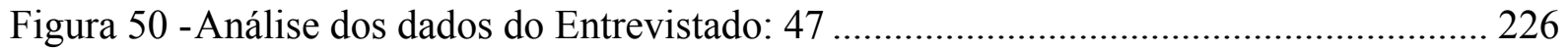

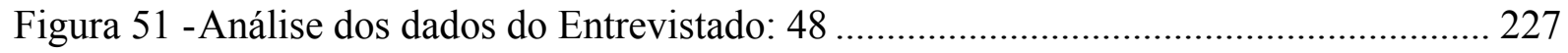

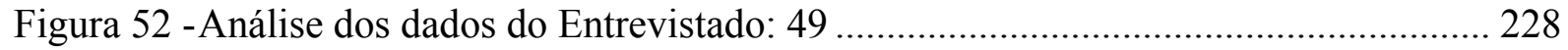

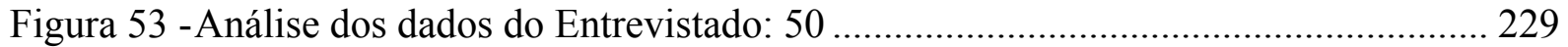


Um doutorado é uma procura de uma nova Identidade. É preciso abandonar hábitos, costumes e valores que lhe são familiares e desvelar um "eu" desconhecido. Não são poucas as crises de Identidade até que se encontre um tema com o qual se identifique. Quando tudo parece sem sentido e incerto, quando as verdades deixam de ser o que são, você está próximo de ser o que você não era. Mas você de alguma forma continua não sendo... 
É possível identificar dentre os estudos sobre as transformações do contexto social da atualidade dois grandes temas sobre os quais pesquisadores e estudiosos têm se debruçado e despendido uma grande parte de suas reflexões. O primeiro tema trata das transformações do Trabalho, abordando questões que vão da forma como é executado e compreendido pelo indivíduo à reflexão sobre sua centralidade enquanto categoria social de análise. O segundo, preocupa-se com o crescimento e valorização do Consumo, sendo que as problemáticas associadas a este tema possuem um espectro amplo de discussões que partem das questões ambientais até a discussão do consumismo como uma doença psicopatológica.

Há, dentre os dos estudos sobre o Trabalho, uma forte corrente de autores que afirma que essa variável está perdendo a sua relevância social, fruto das reconfigurações políticas, econômicas e tecnológicas às quais nossa sociedade tem sido submetida. Outras esferas de natureza não-laboral, passariam a ocupar o espaço do trabalho na sociedade e, conseqüentemente, na vida do indivíduo. Ao mesmo tempo, há, nos estudos sobre o Consumo, uma linha clara de pensamento que delineia a sua valorização no contexto social, tornando-se um forte ponto de referência para os sujeitos.

Embora as questões sejam de natureza extremamente diversa, há um ponto de interligação íntima entre os dois temas. O consumo e o trabalho materializam-se no contexto do espaço organizacional, nas relações de produção e aquisição de produtos e serviços. Acima de tudo, é no indivíduo, enquanto produtor e consumidor, que esses dois universos distintos chocam-se e mesclam-se. A realidade, seja ela objetiva ou subjetivamente constituída, opera-se no indivíduo, que cria e vive dentro de suas verdades.

A complexidade da lógica no pensamento sobre os dois temas torna-se mais vívida quando se entende que não é apenas uma análise de contradições sociais, mas também de antagonismos intrínsecos aos indivíduos que estão inseridos neste contexto. Se por um lado há funções opostas que são conduzidas para uma interligação e interação social entre trabalhadores e consumidores, por outro, a dialética do consumo e trabalho acontece dentro do universo subjetivo dos indivíduos, uma vez que estes trabalham e consomem também.

Dentre tantos elementos constituídos a partir da relação entre o sujeito e o mundo objetivo, a Identidade é a verdade que o indivíduo constrói sobre si para si e para o mundo. A Identidade parte das, e é o ponto de partida para, suas crenças sobre o mundo e sobre quem ele é. A Identidade posiciona o sujeito nas relações sociais, dando sentido de pertencimento e 
exclusão, sobre quem ele é e quem não é. Enquanto constructo que é socialmente constituído, a Identidade reflete cada contexto social em que o indivíduo está imerso. Num contexto complexo como o atual, cheio de contradições, que nega verdades que outrora eram entendidas como absolutas, em que as incertezas parecem sobrepor às convicções mais concretas do ser humano, as Identidades tornam-se igualmente complexas, refletido as ambigüidades do sujeito na sua relação com seu mundo particular.

Por isso mesmo, o constructo Identidade é um importante conceito, não só para compreender as relações entre indivíduos dentro de um processo de interação social, mas a relação do indivíduo consigo mesmo.

Fruto da interligação de realidades sociais distintas e berço de discursos contraditórios, as organizações são locais privilegiados de estudos sobre a sociedade atual, pois reúnem no mesmo espaço indivíduos tão diversos quanto a realidade permite, ora como trabalhadores, ora como consumidores. As organizações não só produzem bens e serviços, mas transformam a "matéria" humana, criando trabalhadores-consumidores e consumidores-trabalhadores.

É neste contexto que esta pesquisa se insere, procurando compreender e analisar duas realidades, o trabalho e o consumo, que, por mais que possam parecer distintos e distantes, estão íntima e inextrincável e inexoravelmente interligados.

Procurando desenvolver essa temática dentro de uma lógica em que se possa compreender as questões envolvidas nesta pesquisa, esta tese está organizada em seis capítulos. No primeiro capítulo, "O Problema de Pesquisa", procurou-se antecipar as questões teóricas associadas com as perguntas orientadoras do trabalho. Entretanto, é na fundamentação teórica que essas questões ganharam maior profundidade. Ainda no primeiro capítulo foram expostos o objetivo geral e os específicos, bem como procurou-se expor a relevância do tema e o desenho teórico da pesquisa.

O segundo capítulo, intitulado "Fundamentação Teórica da Pesquisa", expõe o constructo Identidade, partindo de suas concepções, desenvolvendo-o como elemento de uma construção social e finalizando com as ligações dentro do mundo do trabalho. Em seguida, discute-se as transformações sociais, com uma ênfase maior no trabalho, debatendo também o consumo dentro do que a literatura discute sobre o tema. Por fim, apresenta-se o trabalho bancário, configurando-o dentro do cenário atual, procurando mostrá-lo diante das transformações que 
sofreu nos últimos anos, permitindo compreendê-lo como setor que reflete parte das metamorfoses que a sociedade vem sofrendo, configurando-o como referência importante para compreender a temática que está sendo discutida.

No capítulo intitulado "Aspectos Metodológicos da Pesquisa”, Capítulo 3 deste trabalho, foram expostas e justificadas as opções metodológicas. Procurou-se destacar ao longo desta parte que as escolhas, tanto da abordagem, do instrumento, quanto do tratamento dos dados, deram-se quase que como uma conseqüência da definição conceitual de Identidade Social utilizada nesta tese.

O Capítulo 4 expõe, como seu próprio nome indica, os resultados das análises dos dados dentro das categorias provenientes das escolhas metodológicas descritas no capítulo anterior. Além dessas categorias, expôs-se um caso entendido como relevante para a compreensão do tema estudado. Por fim, apresentou-se os resultados do focus group realizado com os bancários.

As "Conclusões" da pesquisa são apresentadas no Capítulo 5, expondo os elementos considerados mais relevantes para responder as perguntas orientadoras deste estudo.

No capítulo seguinte, Capítulo 6, que se intitulou “(In)conclusões e Recomendações”, fez-se reflexões sobre novas questões que surgiram ao longo do trabalho, bem como recomendações para estudos posteriores. Considerou-se, na elaboração desse capítulo, que, o quê não se concluiu, também é relevante para o conhecimento que se procura acumular.

Indica-se também como extremamente relevantes para a leitura deste trabalho os apêndices, onde se encontram o roteiro de entrevista, bem como os seus quadros de análise e as análises individuais de cada entrevistado. Estas últimas refletem grande parte do tratamento dos dados, dentro da lógica do sujeito produtor do discurso.

Antecipo o pedido de desculpas àqueles que acharem ousadia expor no início de cada capítulo os pensamentos que acompanharam cada etapa desta tese. Expressas verbalmente ou não, tais reflexões se fizeram presentes em cada linha que se consubstanciou neste trabalho. 
CAPÍTULO 1 - O PROBLEMA DE PESQUISA

Problema mesmo é quando você, mesmo cercado por muitos, efetivamente não tem nenhum. 


\subsection{DeFINIÇÃo DA SITUAÇÃO-PROBLEMA}

O problema desta pesquisa parte de três constatações tratadas pela delimitação teórica de alguns autores: as transformações do mundo do trabalho e da sociedade do consumo afetando as instituições ${ }^{1}$ sociais que tradicionalmente servem de referência para as Identidades; a Identidade e suas características enquanto constructo teórico socialmente construído; e o trabalho bancário, suas metamorfoses e suas características como prestação de serviços. Expõem-se concisa e sucintamente essas constatações, sendo que no referencial teórico são tratadas em profundidade e referenciadas pelos autores.

Na primeira constatação, tendências têm sido descritas em relação ao atual contexto e seus efeitos sobre o indivíduo e a sociedade (BAUDRILLARD, 1991; GIDDENS, 1991; HALL, 1999; SANTOS, 2002; BAUMAN, 2005). Primeiramente que as instituições sociais tradicionais, enquanto quadros referenciais de valor para os indivíduos na sociedade, passam por processos de questionamento e revisão. Dentre as inflexões de valores delineadas, o trabalho estaria perdendo seu lugar no quadro de referência do indivíduo, dando espaço para outras dimensões de natureza não-laboral (Linhart, 1991; ANTUNES, 1995; HALL, 1999; De MASI, 2000; SENNET, 2004; BAUMAN, 2005). Ou seja, os valores e instituições sociais tradicionais, que sempre foram norteadores do indivíduo, de sua Identidade Social e de suas ações, começam a ser questionados e suplantados. O recrudescimento dos valores da sociedade de consumo no ideário do sujeito social é apontado dentre esses novos quadros de referência.

Na segunda constatação, a teoria discute que a Identidade é uma variável complexa e em constante transformação, sendo fruto de relações do indivíduo com seu contexto social e com o seu universo íntimo (BERGER; LUCKMANN, 1985; HALL, 1999 e 2000; GuSTAVSSON, 2005).

A Identidade se constitui em um processo de interação entre os sujeitos e o seu meio, sendo

\footnotetext{
${ }^{1} \mathrm{O}$ termo instituições está sendo utilizado dentro da concepção de Berger e Luckmann (1985), como parte da objetivação de valores de natureza subjetiva no ideário social, em um determinado contexto.
} 
este último considerado no sentido amplo, envolvendo diversas esferas sociais. Além disso, a teoria direciona para constatações de que a Identidade passa por um processo de crise e reposicionamento perante os novos contextos sociais (MERCER, 1990 apud WoODWARD, 2000; SILVA, 2000), constituindo-se de forma múltipla e fragmentada (HALL, 1999; GIDDENS, 2002; BAUMAN, 2005).

Na terceira constatação, observa-se que transformações tecnológicas, políticas, econômicas, sociais e gerenciais mudaram completamente as configurações do trabalho nas últimas décadas. Ao mesmo tempo, foi possível acompanhar uma série de metamorfoses sociais que modificaram as relações do indivíduo com seus pares no trabalho e fora dele. Especificamente no trabalho bancário, autores (VALle, 1995; FreITAS, 1995; ACCORSI, 1992; GOMES, 1994; RIBEIRO, 1999) descrevem mudanças que alteram significativamente a relação do profissional com seu trabalho. Ou seja, dentre os aspectos objetivos, o trabalho bancário é descrito como sendo representante legítimo de um contexto que é marcado pelo "estranhamento", na concepção enfocada por Antunes (1995), e pela falta de referência enquanto constituidor de sujeitos sociais, na medida em que é descrito como um "trabalho vazio" (CODO; SAMPAIO, 1992; FAlqueto, 1997). Por outro lado, o aumento da competitividade do setor, aliado ao fato de se configurar como uma prestação de serviços, faz com que haja uma sobrevalorização da figura do consumidor nos processos organizacionais das empresas do setor.

A primeira constatação está interligada à segunda, na medida em que as mudanças sociais têm afetado as Identidades, reposicionando-as perante o novo contexto. O setor bancário, em função de suas características, por ser parte do setor de prestação de serviços e em função das reconfigurações nas últimas décadas, revela-se um locus em que as mudanças possivelmente estão influenciando as Identidades Sociais. Na medida em que os valores referenciais e as instituições sociais, nas quais a Identidade Social se baseia, são questionados, que há uma valorização do consumo e do consumidor e que o setor bancário encontra-se em um contexto de transformação de seu trabalho, passa-se a formular as questões de pesquisa. 


\subsection{QUESTÃO DE PESQUISA}

Tendo com base os elementos discutidos na situação-problema, pergunta-se: como o consumo e o trabalho interferem nas Identidades Sociais dos bancários no contexto atual?

Nesse sentido, a questão principal deste trabalho é:

verificar como a Identidade Social do bancário se manifesta, tendo como ponto de partida a sua relação com o trabalho em transformação e o seu posicionamento na sociedade de consumo.

\subsection{OBJETIVOS}

\subsubsection{Objetivo geral}

Compreender como a Identidade Social se manifesta no discurso dos bancários perante a contraposição de suas visões sobre o consumo e o trabalho, estabelecendo as possíveis interligações entre estes dois elementos.

\subsubsection{Objetivos específicos}

a. Determinar quais são as tipificações ${ }^{2}$ feitas pelos bancários sobre o "Ser Trabalhador" e o "Ser Consumidor", delineando como descrevem a si próprios - ou seja, a descrição do "eu" - enquanto consumidores e trabalhadores;

b. Determinar as tipificações feitas pelos bancários sobre o "Ser Trabalhador" e o "Ser Consumidor", delineando como descrevem os demais indivíduos - ou seja, a descrição do "outro" - enquanto consumidores e enquanto trabalhadores;

c. Descobrir quais são as descrições que os bancários fazem do trabalho e, a partir das

\footnotetext{
${ }^{2} \mathrm{O}$ conceito de tipificação foi trabalhado por Berger e Luckmann (1985) e foi melhor detalhado nos capítulos Fundamentação Teórica da Pesquisa e Aspectos Metodológicos da Pesquisa.
} 
descrições, delinear quais valores são associados a esta variável;

d. Descobrir quais são as descrições que os bancários fazem do consumo e, a partir das descrições, delinear quais valores são associados a esta variável;

e. Compreender como Identidade Social se expressa quando associada a elementos como o trabalho, a categoria profissional, a organização, o consumo e o consumidor;

f. Compreender como acontecem as relações entre o trabalho e o consumo enquanto elementos constituidores da Identidade Social do bancário e suas possíveis conseqüências subjetivas.

\subsection{RELEVÂNCIA DO ESTUDO}

A Identidade Social é um constructo importante para os estudos de Administração na medida em que define o posicionamento dos sujeitos nos relacionamentos sociais dentro da organização, além de interferir no sentimento de pertencimento e exclusão (diferenciação) no que tange os grupos e as organizações (ASHFORTH; MAEL, 1989 apud StEVANATO, 2004; Caldas, 1999; Gaulejac, 2002; Stevanato, 2004; Gustavsson, 2005). Conhecer melhor como este constructo está sendo afetado pelo contexto atual permite compreender mais sobre os indivíduos dentro das organizações e como os trabalhadores se relacionam entre si, com a organização e com a comunidade a quem prestam seus serviços.

Além disso, a Identidade Social influencia e é influenciada pelos aspectos organizacionais e gerenciais, na medida em que estes definem o contexto micro-social em que o indivíduo opera, sendo objeto importante para compreender como as relações sociais, dentro das organizações, se estruturam (Berger; LuCKMAnN, 1985; AKTOuF, 1998; SENNET, 2004; STEVANATO, 2004).

Outro ponto que denota a relevância deste estudo é que o trabalho constituiu-se como uma das referências importantes para o indivíduo, principalmente em uma sociedade com base no mercado como a nossa, sob dois aspectos: o aspecto subjetivo e o aspecto objetivo (Braverman, 1987; Borzeix; Linhart, 1996; PAuchant, 1996; Fischer, 1996; CAldas, 1999; EnRIQUeZ, 1999; SENNET, 2004; CiAmpA, 2005; Tose, 2005). No primeiro aspecto, subjetivo, o trabalho dá Identidade Social na medida em que cria a noção de pertencimento e exclusão (diferenciação) em relação a uma determinada classe sócio-econômica, profissão ou 
organização (FAlqueto, 1997; CAldAs, 1999; EnRIQueZ, 1999; Gustavsson, 2005). Para alguns autores, o trabalho é fonte principal da constituição do homem enquanto ser social, uma vez que é por meio dele que este media sua relação com a natureza, subjugando-a, e a sua relação com os demais homens (ANTUNES, 1995; TEIXEIRA, 1999; ENRIQUEZ, 1999; ARENDT, 2004). Ao mesmo tempo, a Identidade Social se constitui a partir da ação de execução de um trabalho (CALDAS, 1999; CIAMPA, 2005), ou seja, o sujeito social se constitui como tal, a partir do que ele faz, de suas ações no seu ambiente produtivo (TEIXEIRA, 1999; ARON, 2003; ARENDT, 2004).

Autores constroem argumentações de que o trabalho se constitui uma referência para a construção do sujeito social a partir da re-significação de seus valores, principalmente ao longo da Era Moderna ${ }^{3}$, em função de uma série de elementos que definiram as opções de desenvolvimento social (EnRIQueZ, 1999; Giddens, 2002; SEnNeT, 2004; ARENDT, 2004; BAUMAN, 2005). Ressalta-se que os valores da sociedade moderna enaltecem os que estão inseridos no mercado de trabalho em contraposição aos que estão excluídos (CALDAS, 1999; ENRIQUEZ, 1999). Não que, em outros momentos históricos distintos, o trabalho não seja considerado relevante, mas a lógica econômica desse período traz uma conotação específica para a atividade laboral do homem em termos sociais, contrapondo outros valores referentes às atividades associadas ao tempo livre humano (ENRIQUEZ, 1999; DE MASI, 2000). Ao longo da Era Moderna, a inserção do indivíduo na sociedade ficou marcada pelo trabalho, uma vez que a concepção de desenvolvimento social é atrelada, de forma inextrincável, à noção de produção e consumo de bens (ENRIQUEZ, 1999; ARENDT, 2004). Ou seja, o projeto de desenvolvimento social na Era Moderna enfatiza o caráter de atenção às carências materiais dos indivíduos (ENRIQUEZ, 1999). Esta constatação é importante na medida em que se reitera que o constructo Identidade Social é moldado pelos valores vigentes em um contexto específico (BERGER; LUCKMANN, 1985).

\footnotetext{
${ }^{3}$ Está-se apropriando do conceito de Era Moderna dentro do mesmo sentido que os autores citados ao longo do texto. Em geral, a literatura trata como Era Moderna o período que compreende os movimentos humanismo, cartesianismo e iluminismo.
} 
Já no aspecto objetivo, é por meio do trabalho que o indivíduo obtém sua sobrevivência material. É com o trabalho que o indivíduo tem acesso a recursos que lhe permitirão ter os bens que necessita consumir para sua existência humana (ANTUNES, 1995; TEIXEIRA, 1999; ARON, 2003; ARENDT, 2004). É interessante ressaltar que há aspectos subjetivos inerentes e interligados aos aspectos objetivos, de forma que o ato de consumir possui um lado simbólico diretamente ligado à construção do sujeito social (WOODWARD, 2000; SILVA, 2000; CoELHO, 2002; BAUMAN, 2005).

Neste sentido, a relevância desta pesquisa também está em contribuir para esta discussão sobre o trabalho e suas metamorfoses sociais, além de buscar conexões entre o mundo do trabalho e a sociedade do consumo. 
1.5. DESENHO TEÓRICO DA PESQUISA

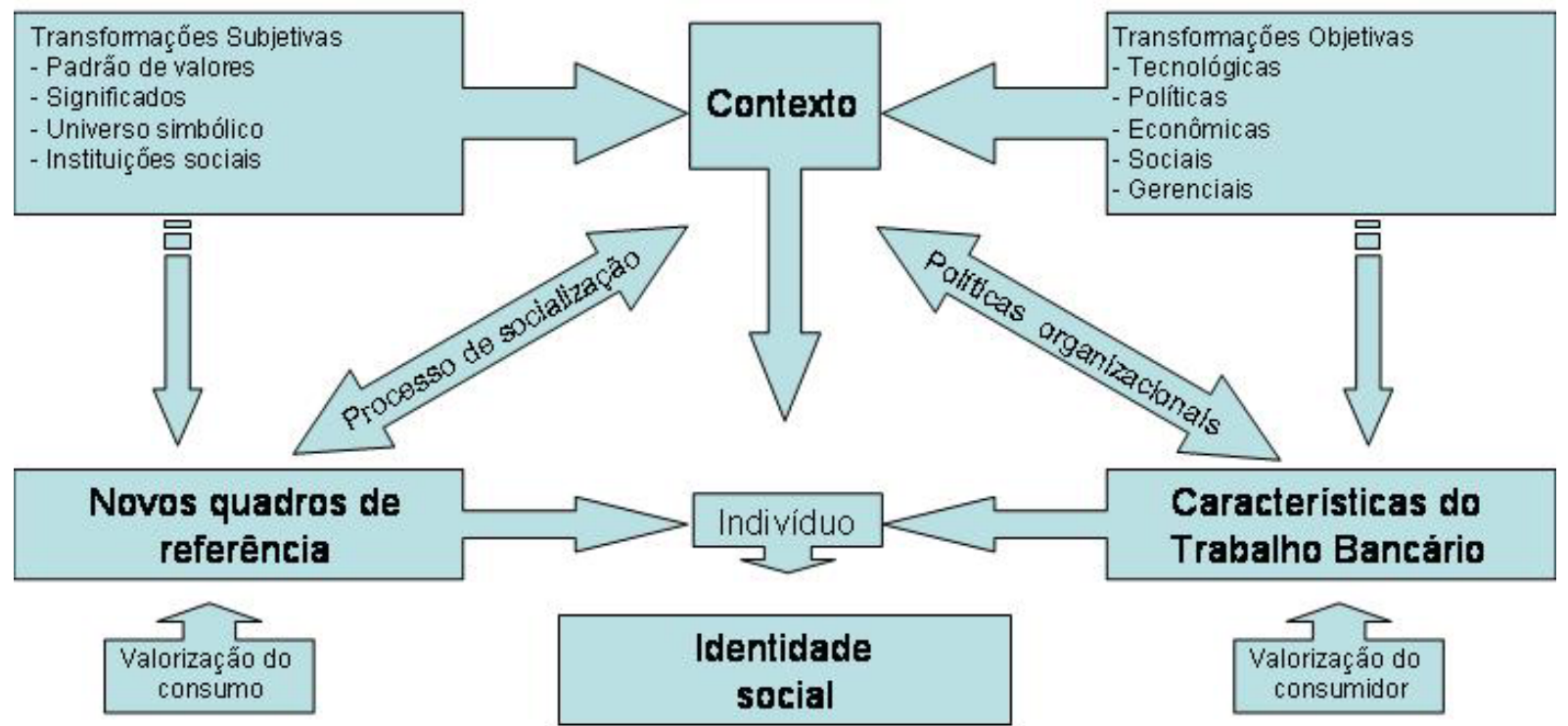

Questões de pesquisa

Como o consumo e o trabalho interferem

nas Identidades Sociais dos bancários no contexto atual?

Figura 1 - Desenho teórico da pesquisa 
Valer-se dos pensamentos alheios não é simplesmente se apropriar de um aglomerado de frases e falas. É vivenciar outras histórias e estórias criadas a partir da intimidade com o mundo que não nos pertence. 


\subsection{CONSTRUINDO IDENTIDADES}

Esta pesquisa sobre Identidade no mundo do trabalho tem como ponto de partida a consideração de que, apesar de as discussões sobre o constructo terem início no período helênico, ainda há muito a se estudar sobre o que a define e como se comporta diante dos novos valores e transformações da sociedade. É preciso explorar essa variável na medida em que se constitui um dos elementos que configura o pensamento e a subjetividade do ser humano.

Por que falar de Identidade? Segundo Bauman (2005), Identidade tem se tornado um tema que vem crescendo nas discussões atuais.

É realmente um dilema e um desafio para a sociologia - se você se lembrar de que, há apenas algumas décadas, a "identidade" não estava nem perto do centro de nosso debate, permanecendo unicamente um objeto de meditação filosófica. Atualmente, no entanto, a "identidade" é o "papo do momento", um assunto de extrema importância e evidência. (BAUMAN, 2005, p. 22-23).

Para Mercer (1990 apud WoODWARD, 2000) a Identidade torna-se relevante num contexto em que se acredita que ela esteja em crise.

Quase todo mundo fala agora sobre "identidade". A identidade só se torna um problema quando está em crise, quando algo que se supõe ser fixo, coerente e estável é deslocado pela experiência da dúvida e da incerteza. (MERCER, 1990 apud WOODWARD, 2000, p. 19).

A importância da Identidade enquanto constructo não se restringe aos momentos de crise. $\mathrm{O}$ que os autores denotam é que, nestes momentos, são ressaltadas as conseqüências da degradação da Identidade e que, atualmente, estamos em um contexto propenso a esse tipo de questão.

Para compreender o que faz da identidade um conceito tão central, precisamos examinar as preocupações contemporâneas com questões de identidade em diferentes níveis. Na arena global, por exemplo, existem preocupações com as identidades nacionais e com as identidades étnicas; em um contexto mais "local", existem preocupações com a identidade pessoal, por exemplo, com as relações pessoais e com a política sexual. Há uma discussão que sugere que, nas últimas décadas, estão ocorrendo mudanças no campo da identidade - mudanças que chegam ao ponto de produzir uma “crise da identidade". (WOODWARD, 2000, p. 16).

A Identidade é responsável, dentre outras coisas, pelo posicionamento do indivíduo perante aos outros, na forma de relações sociais, e perante aos objetos, na relação com o mundo natural (WoOdWARd, 2000; CoElho 2002; CiAmPa, 2005; BAuman, 2005). Ao se desvelar e apreender a Identidade enquanto constructo, compreende-se a relação do indivíduo - no seu aspecto mais íntimo e subjetivo - com o mundo natural objetivo e universo social 
objetivado(BERGER; LUCKMANN, 1985; GIDDENS, 2002).

Além disso, a Identidade está diretamente relacionada à ação do Indivíduo. Ciampa (2005) conclui em suas pesquisas que, mais do que uma "adjetivação", a Identidade é "verbo", no sentido de que se faz e é feita pela ação do homem sobre as coisas e sobre si mesmo. Entender a Identidade, em parte, é entender a ação do indivíduo e as suas implicações, ou seja, seu trabalho, o que faz o indivíduo.

No contexto das organizações e dos estudos de administração, também se aplicam as considerações acima enfocadas. Compreender a Identidade no contexto organizacional implica entender parte das relações sociais que acontecem no trabalho, a relação do indivíduo com suas atividades e o comportamento do indivíduo dentro da organização, entendido de forma ampla. Isso permite inferir que a Identidade é, em essência, um constructo que auxilia na compreensão de outras variáveis organizacionais. Stevanato (2004) assim se remete à importância dos estudos de Identidade dentro do contexto organizacional ao resgatar o trabalho de Ashforth e Mael (1989):

- Os indivíduos procurariam escolher as atividades que são mais congruentes com os aspectos salientes de suas identidades e que eles tendem a dar apoio para instituições que encarnam tais identidades;

- A identificação social afetaria os resultados tradicionalmente associados à formação de equipes, incluindo a coesão intragrupal, cooperação e altruísmo e avaliações positivas do in-group com o qual se identificam.

- A identificação social também favoreceria a internalização e a aderência aos valores e normas do in-grupo (sic). Além de facilitar a homogeneidade de atitudes e comportamentos;

- Finalmente, na medida em que o indivíduo se identificasse com um grupo, os valores e práticas do in-group se tornariam mais salientes e percebidas como únicas e especiais. (ASHForth; MAel, 1989 apud SteVAnAto, 2004, p. 34).

Entretanto, dentro dos estudos organizacionais no Brasil, pode-se dizer que a Identidade ainda é um constructo que carece ser mais explorado, sendo necessário desvendar as contribuições possíveis que ela pode propiciar para a compreensão das organizações e dos indivíduos que as compõem.

\subsubsection{Delimitações conceituais de Identidade}

A definição do que é Identidade, enquanto variável de estudo, é concomitantemente complexa e simples. Complexa porque qualquer definição conceitual que tente sintetizá-la tende a cair 
no simplismo de suas significações, sempre deixando a desejar no que diz respeito ao que ela realmente é (GuSTAVSSON, 2005). Jackson e Smith (1999) afirmaram que esta é uma dificuldade enfrentada por diversos pesquisadores, principalmente ao tentar conciliar uma definição conceitual e operacional do constructo. Nas palavras destes autores:

Contudo, como foi detalhado adiante, por várias razões práticas, empíricas e teóricas, os pesquisadores conceituaram e operacionalizaram o constructo em numerosas e, algumas vezes, em maneiras absolutamente disparatadas. Embora muitas pesquisas sobre a identidade social tenham ocorrido[...] permanece uma grande quantidade de inconsistência conceitual e operacional através dos estudos e incongruência entre definições conceituais e operacionais do constructo dentro dos estudos (JACKSON; SMITH, 1999, P. 120).(Tradução nossa) ${ }^{4}$

Gustavsson (2005, p. 11) assim comenta sobre esta questão, buscando apoio no trabalho de Erikson (1968).

Em resumo, a identidade individual é difícil de definir de uma forma precisa. Erikson, um dos pesquisadores pioneiros neste campo, ele mesmo escreveu: 'Quanto mais alguém escreve sobre esse assunto, mais a palavra se torna um termo para alguma coisa impenetrável, uma vez que é universal. Alguém somente pode investigá-la estabelecendo sua essencialidade em vários contextos' (Tradução nossa) ${ }^{5}$

Por outro lado, a definição de Identidade torna-se simples - o que não quer dizer que ela perca sua complexidade conceitual - na medida em que se entende o que ela representa em termos reais para o indivíduo. Berger e Luckmann (1985) Hall, (2000), Woodward, (2000), Silva (2000) e Gustavsson (2005) recorreram à pergunta “quem sou eu?" como sendo emblemática para a definição de Identidade. Trabalhar a Identidade é compreender e apreender a definição do "ser", enquanto entidade ontológica.

4 "However, as detailed later, for various practical, empirical, and theoretical reasons, researchers have conceptualized and operationalized the construct in numerous and sometimes quite disparate ways.(...) Although much research on social identity has taken place (...) there remains a great deal of conceptual and operational inconsistency across studies and incongruence between conceptual and operational definitions of the construct within studies.”

5 "In summary, individual identity is difficult to define in a precise manner. Erikson, one of the pioneer researchers in the field, himself wrote: 'The more one writes about this subject, the more the word becomes a term for something unfathomable as it is all-pervasive. One can only explore it by establishing its indispensability in various contexts'." 
Identidade, para Woodward (2000), está associada também a uma relação dicotômica que dá sentido ao sujeito. Neste sentido, a Identidade define o que o indivíduo "é" e aquilo que ele "não é". Em outras palavras, ser Brasileiro implica negar todas as outras nacionalidades. A autora, a partir dessa constatação, descreve que a Identidade também significa "pertencimento" e "exclusão" (diferenciação), na medida em que se faz parte ou não de determinado coletivo a partir da sua Identidade. Indiretamente a autora desvela um lado intrínseco da noção de Identidade que é seu caráter social, embora, como será definido adiante, também é biológica e psicologicamente definida.

Outro aspecto relevante delineado por Woodward (2000) é que a Identidade só faz sentido se houver uma relação com o "outro", ou seja, ela é relacional. "A identidade é, na verdade, relacional, e a diferença é estabelecida por uma marcação simbólica relativamente a outras identidades" (WOODWARD, 2000, p.14). Isto implica que a Identidade está associada à concepção de alteridade que o indivíduo tem e como ele se relaciona com o outro, e isto reforça seu caráter social. De forma análoga, Berger e Luckmann (1985) afirmam que a compreensão do "ser" parte de um processo relacional, de forma que "esta reflexão sobre mim mesmo é tipicamente ocasionada pela atitude com relação a mim que o outro manifesta. É tipicamente uma relação "de espelho" às atitudes do outro (BERGER; LUCKMANN, 1985, p. 48).

Essa relação da definição da Identidade a partir do outro, para Woodward (2000), tem origens na constituição primária da Identidade. Para a autora, o indivíduo somente começa a ter a consciência de que é um "ser" quando ainda está na infância e percebe que é diferente de outro "ser", a mãe. Isto porque, ao nascer e nos primeiros anos de vida, esta distinção ontológica não é percebida, sendo que a criança não faz a distinção entre ela e a mãe. Dialeticamente, ao negar a mãe e reconhecer sua alteridade, a criança se faz um "ser".

Para Berger e Luckmann (1985) a socialização primária, feita pelos pais, é responsável pela constituição do núcleo do "ser" ao definir parte do universo simbólico sob o qual o indivíduo vai viver e conviver socialmente. Entretanto, a Identidade sempre será "remodelada" pelas novas relações sociais estabelecidas pela socialização secundária. Para esses autores, a socialização secundária está diretamente associada ao fato de a estrutura social tornar-se mais complexa que, por meio da divisão social do trabalho, constitui a necessidade da formação das consciências profissionais específicas. Ou seja, o trabalho e a profissão são elementos da 
construção do ser social.

Corroborando as idéias de Berger e Luckmann (1985), Gaulejac (2002) sugere uma Identidade herdada, que vem da nascença; uma Identidade adquirida, ligada fortemente à posição sócio-profissional e; uma Identidade esperada, que é a pela qual nós almejamos ser reconhecidos (pelo outro). O autor ainda acrescenta que tais Identidades entram em estado de tensão umas com as outras, a partir da vivência do indivíduo em suas diversas esferas pessoais e sociais.

Ciampa (2005) desenvolve o conceito de Identidade como parte de um processo contínuo de construção com base nas relações sociais. Cada indivíduo encarna as relações sociais, configurando uma identidade pessoal. Uma história de
vida. Um projeto de vida. Uma vida-que-nem-sempre-é-vivida, no emaranhado das relações
sociais.

Uma identidade concretiza uma política, dá corpo a uma ideologia.

No seu conjunto, as identidades constituem a sociedade, ao mesmo tempo em que são constituídas, cada uma por ela. (CIAMPA, 2005, p.127).

O mesmo autor trata a Identidade como uma questão social e política, e, concomitantemente, resgata a visão do constructo como um processo dinâmico. Recorre ainda à dialética materialista para explicar o fenômeno da Identidade, procurando mostrar como os aspectos concretos da realidade social podem afetar na constituição das formas identitárias, por meio das tensões do contexto sobre o indivíduo.

Inspirado nos estudos de Ciampa (2005) e contextualizando a pesquisa da Identidade, Laurenti e Barros (2000, p.1), ratificam a necessidade de entendê-la dentro de um processo que exige a "circunscrição deste homem ao momento atual do mundo globalizado, marcado por um capitalismo desorganizado, a fim de explicitar as novas bases sobre as quais se articula o pessoal e o social na contemporaneidade". Estas autoras partilham da concepção de Identidade como sendo parte de uma construção sócio-histórica. "A identidade não é inata e pode ser entendida como uma forma sócio-histórica de individualidade. O contexto social fornece as condições para os mais variados modos e alternativas de Identidade." (LAURENTI; BARRos, 2000, p.6). Afirmam ainda, de forma semelhante à de Hall (1999), que a Identidade no contexto atual é, em si, uma multiplicidade de posições assumidas pelo indivíduo, que não podem ser consideradas como elemento único e conciso em todas as suas dimensões. 
Neste sentido, levar-se-á em consideração o constructo Identidade nas seguintes representações reais para o indivíduo:

- A Identidade como uma definição do "ser" e do "não ser";

- A Identidade como relacional, definida não só por suas características internas, mas pelas interações sociais com os outros;

- A Identidade como elemento definidor de pertencimento e exclusão (diferenciação);

- A Identidade como sendo múltipla em suas manifestações;

- A Identidade como uma construção social;

- A Identidade como verbo, ou seja, como ação.

Para entender mais sobre Identidade, é preciso compreender algumas de suas concepções.

\subsubsection{Concepções de Identidade}

A Identidade passa por duas grandes concepções, segundo Woodward (2000): a visão essencialista e a visão não essencialista. A primeira vê a Identidade como possuidora de elemento estabilizador e único que define o ser, não sendo mutável ao longo do tempo. A segunda concepção entende que a Identidade é um processo relacional e de compartilhamento de elementos comuns que definem o ser, mas que mudam ao longo do tempo. Nas palavras da autora:

$\mathrm{Na}$ base da discussão sobre essas questões está a tensão entre perspectivas essencialistas e perspectivas não-essencialistas sobre identidade. Uma definição essencialista da identidade "sérvia" sugeriria que existe um conjunto cristalino, autêntico, de características que todos os sérvios partilham e que não se altera ao longo do tempo. Uma definição não-essencialista focalizaria as diferenças, assim como as características comuns compartilhadas, tanto entre os próprios sérvios quanto entre os sérvios e outros grupos étnicos. (WOODWARD, 2000, p. 12).

Gustavsson (2005) também explora esta dicotomia sobre as concepções de identidade, entendendo como uma cisão de visões que são incompatíveis. A figura abaixo mostra como as concepções são divididas. 


\section{Concepçōes de self e Identidade}

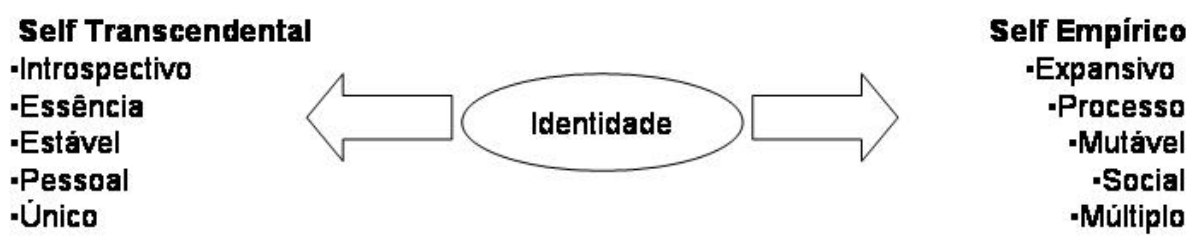

Figura 2 - $\quad$ As concepções de self e Identidade segundo Gustavsson (2005)

Fonte: Adaptado de Gustavsson (2005, p. 12)

Entretanto, a partir do resgate teórico de alguns autores, principalmente de Hall (1999) e de Berger e Luckmann (1985), é possível delinear que as concepções não são necessariamente antagônicas, mas, pelo contrário, há uma complementaridade de visões. Hall (1999), ao reconstruir historicamente as visões de Identidade, mostra como em sociedades de menor mobilidade social, a Identidade tende a ser compreendida como fixa e estável, mas com as alterações e conseqüente fragilidade das instituições sociais de hoje, a Identidade é vista e vivenciada como uma celebração móvel.

Como a Identidade é vista como um constructo que perpassa diversos elementos da constituição do ser - biológicos, psicológicos e sociais - há uma interação contínua de variáveis que ora estão estáveis e ora estão em processos de reposicionamento. Berger e Luckmann (1985) descrevem a Identidade associada aos processos de socialização. No que tange a socialização primária, uma vez que é carregada de emoções vinculadas aos progenitores, há tendência de ser mais constante e estável (não quer dizer imutável). Já a socialização secundária é mais fluida e cambiante, sendo, portanto, ponto de flexibilidade para as Identidades.

\subsubsection{Identidade: uma reconstrução histórica}

O estudo da Identidade perpassa por diversos momentos históricos e o início da compreensão dessa variável tem origem no pensamento aristotélico (HALL, 1999). Mas é a partir do Iluminismo que a Identidade ganha contornos e configurações mais lúcidas sobre a sua constituição e a relação com o indivíduo.

Stuart Hall faz um resgate de três visões históricas da Identidade sendo que considera que em cada uma das concepções "a individualidade era 'vivida' e 'conceptualizada' de forma 
diferente" (HALl,1999, p.25). Nesse sentido, o desenvolvimento e a compreensão do constructo Identidade caminha paralelamente à própria forma como ele se manifesta socialmente.

$\mathrm{Na}$ primeira concepção, o sujeito do Iluminismo, o indivíduo é visto como dotado de um centro essencial fixo que lhe dava Identidade, independente das alterações do mundo. Essa concepção foi um reflexo do pensamento cartesiano que via na mente do indivíduo uma essência única norteando sua individualidade. Ao mesmo tempo, a falta de mobilidade social e as fortes influências do Estado e da Igreja serviam como aparato estabilizador das Identidades, vinculando-as a uma delimitação geográfica e a uma condição nata do indivíduo. Bauman (2005) afirma que esta vinculação da Identidade à "natividade do nascimento" foi crucial para a legitimação do Estado.

A ficção da "natividade do nascimento" desempenhou o papel principal entre as fórmulas empregadas pelo nascente Estado moderno para legitimar a exigência de subordinação incondicional de seus indivíduos (de alguma forma, curiosamente, desprezada por Max Weber em sua tipologia das legitimações). (BAUMAN, 2005, p. 27).

Ao mesmo tempo, Bauman (2005) deixa claro que a Identidade é parte de uma construção social e que, nos dias atuais, a mesma concepção está sendo utilizada para desvincular as Identidades dos contextos locais e nacionais, migrando-se para um conceito de uma Identidade cosmopolita. Ou seja, as mesmas variáveis identitárias que possam ser entendidas como forças estabilizadoras da Identidade em um determinado contexto, em outro, a desestabilização destas variáveis pode ser igualmente vivenciada pelos indivíduos sem que isto se configure como uma incoerência conceitual do constructo Identidade. Em outras palavras, Identidade enquanto essência ou não-essência fazem parte da realidade do mesmo constructo.

O sujeito sociológico, dentro da segunda concepção trabalhada por Hall (1999), "ainda tem um núcleo ou essência interior que é o 'eu real', mas este é formado e modificado num diálogo contínuo com os mundos culturais 'exteriores' e as Identidades que esses mundos oferecem" (HALL, 1999, p. 11). Nessa visão, a Identidade é constituída na interação simbólico-cultural do indivíduo com a sociedade. Hall (1999) cita como grandes influenciadores dessa visão o pensamento de Marx, Darwin e Adam Smith.

A construção da concepção da Identidade a partir do sujeito sociológico tem o trabalho como um dos elementos centrais, na medida em que ele é entendido como a forma de relação do 
homem com a natureza, construindo a sociedade tal como a conhecemos, dentro de uma concepção de desenvolvimento sócio-historicamente definida (ENRIQUEZ, 1999; TEIXEIRA, 1999; ARENDT, 2004).

Bauman (2005) destaca que nesta interação com a sociedade, ou sua realidade próxima, o indivíduo constrói uma biografia, ou seja, sua história de vida em uma lógica delineada.

\begin{abstract}
Quando a modernidade substituiu os estados pré-modernos (que determinavam a identidade pelo nascimento e assim proporcionavam poucas oportunidades para que surgissem a questão do "quem sou?") pelas classes, as identidades se tornaram tarefas que os indivíduos tinham de desempenhar [...] por meio de suas biografias.[...] Quando se trata de pertencer a uma classe, é necessário provar pelos próprios atos, pela "vida inteira" - não apenas exibindo ostensivamente uma certidão de nascimento -, que de fato se faz parte da classe a que se afirma pertencer. Deixando de fornecer essa prova convincente, pode perder a qualificação de classe, tornar-se déclassé. (BAUMAN, 2005, p. 55-56).
\end{abstract}

Destaca-se que o sujeito sociológico é o expoente da modernidade no século XX. O projeto social que procura unir o trabalho, a racionalidade e o progresso marca a compreensão de um sujeito que se Identifica pelo seu universo produtivo. Bauman (2005) reitera essa visão de sujeito sociológico contextualizado ao Estado de Bem-Estar Social e mostra sua crise a partir da falência desse modelo.

Houve um tempo em que a identidade humana de uma pessoa era determinada fundamentalmente pelo papel produtivo desempenhado na divisão social do trabalho, quando o Estado garantia (se não na prática, ao menos nas intenções e promessas) a solidez e a durabilidade desse papel, e quando os sujeitos do Estado podiam exigir que as autoridades prestassem contas no caso de deixarem de cumprir as suas promessas e desincumbir-se da responsabilidade assumida de proporcionar a plena satisfação dos cidadãos. (BAUMAN, 2005, p. 51-52)

Por fim, a terceira concepção de Identidade é a do sujeito pós-moderno que é, segundo Hall (1999), influenciado pela releitura do pensamento marxista na década de 60 configurando um "anti-humanismo"; pelo pensamento freudiano que divide a Identidade em consciente e inconsciente; pelo trabalho de Ferdinand de Saussure que relativiza o simbólico, o significado e os valores da comunicação humana; pela genealogia do poder de Foucault e no poder disciplinar que dociliza o indivíduo por meio das instituições sociais; e pelos movimentos sócio-ideológicos como o feminismo e os movimentos de 1968 que questionam todas as Identidades que outrora se consideravam como fixas e bem distintas, por exemplo a Identidade sexual, a Identidade cultural, a Identidade política, a Identidade racial dentre outras.

A última concepção da variável mostra não uma única Identidade, mas várias em que o indivíduo se apega em momentos diferentes de sua vida. "Esse processo produz o sujeito pós- 
moderno, conceptualizado como não tendo uma Identidade fixa, essencial ou permanente. A Identidade torna-se uma 'celebração móvel'[...]" (HALL, 1999, p. 12-13). A Identidade percebida como um processo de construção constante, na medida em que ganha um caráter provisório. "A fragilidade e a condição eternamente provisória da identidade não podem ser mais ocultadas. O segredo foi revelado. Mas esse é um fato novo, muito recente.” (BAUMAN, 2005, p.22).

Bauman (2005), denominando o contexto atual de Modernidade Líquida, expõe a Identidade como um questionamento ao sujeito moderno:

A abundância dos compromissos oferecidos, mas principalmente a fragilidade de cada um deles, não inspira confiança em investimentos de longo prazo no nível das relações pessoais ou íntimas. Tampouco inspira confiança no local de trabalho, onde o status social costumava a ser definido, onde a vida continua a ser ganha e os direitos de dignidade e respeito social continuam a ser obtidos ou perdidos. Num artigo recente, Richard Sennett assinala que "um local de trabalho flexível provavelmente não seria o lugar onde alguém desejaria construir um ninho". (BAUMAN, 2005, p. 36).

Consideramos importante compreender que esta pesquisa parte da premissa de que as Identidades, tal qual se delimita teoricamente, estão em constante transformação e são fruto de uma construção sócio-histórica e, ao mesmo tempo, de uma vivência do indivíduo com sua realidade objetiva específica. Não se supõe que haja uma única Identidade, coerente e acabada, embora haja elementos que são provenientes da socialização primária, mais consolidados, e elementos da socialização secundária que se permitem flexibilizar mais.

\footnotetext{
A identidade plenamente unificada completa, segura e coerente é uma fantasia. Ao invés disso, à medida que os sistemas de significação e representação cultural se multiplicam, somos confrontados por uma multiplicidade desconcertante e cambiante de identidades possíveis, com cada uma das quais poderíamos nos identificar - ao menos temporariamente (HALL, 1999, p. 13).
}

Entretanto, não se supõe que as Identidades sejam cambiantes e totalmente mutáveis. Isto será entendido de forma mais clara quando se tratar mais adiante da visão de Identidade como construção social.

\subsubsection{Identidade: olhares interdisciplinares}

Todo indivíduo precisa ser compreendido como um ser biopsicossocial (LIMONGI-FrANÇA, 1990 e 2004), e a constituição das Identidades também é perpassada por esta concepção.

Aktouf (1998) categoriza as fontes de Identidade Pessoal como biológicas - tais como hereditariedade, o corpo, o sexo, a idade -, psíquicas - constituídas a partir dos processos de 
identificação, introjeção, transferência dentre outros - e sociais - origem social, cultural e nacional, profissão, métier, orientação política, religiosa além de outras. Neste sentido, Aktouf (1998, p. 26) define Identidade como "um conjunto bio-psico-social dinâmico que se constrói em um espaço-tempo e que serve para nos definir aos nossos olhos e aos olhos do outro."

Para a compreensão do "ser", e conseqüentemente da Identidade, faz-se necessário um olhar inter e transdisciplinar. Não é por menos que o tema Identidade tem sido objeto de estudo de diversas ciências que, embora em alguns casos não haja conexões diretas entre elas, podem ser entendidas como complementares. Essa característica do constructo, que transcende os limites disciplinares das ciências, revela o lado complexo do tema e parte das dificuldades em compreendê-lo em sua totalidade: conciliar perspectivas diferentes e, em alguns casos, contraditórias, sem perder o sentido de complementaridade.

Woodward (2000) revela estas inter-relações, quando descreve o aspecto biológico da definição da Identidade. Para ela, "O corpo é um dos locais envolvidos no estabelecimento das fronteiras que definem quem nós somos, servindo de fundamento para a identidade - por exemplo, para a identidade sexual.”(WOODWARD, 2000, p. 15). Complementando a concepção de Identidade, a autora mostra que aspectos psicológicos e sociais interferem no aspecto biológico. Woodward (2000, p. 32) acrescenta que "Entretanto, a forma como vivemos nossas identidades sexuais é mediada pelos significados culturais sobre a sexualidade que são produzidos por meio de sistemas dominantes de representação."

Outros aspectos biológicos que são igualmente influenciados ou definidos por aspectos psicológicos e sociais podem ser citados como influenciadores da Identidade tais como raça, deficiências físicas, características marcantes do biótipo do indivíduo dentre outros. Ressaltase, em todos esses casos, que os elementos biológicos passam por uma concepção psicológica e social, fruto de construções sócio-históricas.

Essa é uma característica da relação do homem com sua natureza biológica e com sua existência material. Berger e Luckmann (1985) denotam que os elementos sociais que determinam a Identidade são objetivados de tal forma que passam a se confundir e a serem entendidos como naturais. Ou seja, embora sejam construções sociais, são vivenciados pelos indivíduos como se fossem elementos naturais. Levando-se em consideração o que é natureza e o que é social, os autores afirmam que "Embora seja possível dizer que o homem tem uma natureza, é mais significativo dizer que o homem constrói sua própria natureza, ou, mais 
simplesmente, que o homem se produz a si mesmo." (BERGER; LUCKMANN, 1985, p. 71). Os autores esclarecem ainda o fato de que o processo de objetivação social da Identidade "reproduz" as definições biológicas com as quais o indivíduo nasce, dando um sentido sui generis a cada contexto social. Fica mais claro quando os autores expõem que:

Os pressupostos genéticos do eu são, está claro, dados no nascimento. Mas o eu tal como é
experimentado mais tarde como uma identidade subjetiva e objetivamente reconhecível, não é. Os
mesmos processos sociais que determinam a constituição do organismo produzem o eu em sua
forma particular, culturalmente relativa. O caráter do eu como produto social não se limita à
configuração particular que o indivíduo identifica como sendo ele mesmo [...], mas com o
equipamento psicológico amplo que serve de complemento a essa particular configuração.
(BERGER; LUCKMANN, 1985, p. 74).

$\mathrm{Na}$ medida em que se clarifica que Identidade possui aspectos biológicos, psicológicos e sociais e que estes últimos fazem parte de um elemento volátil que pode ser re-significado, retoma-se o constructo dentro de sua concepção social.

\subsubsection{Identidade como construção social}

Para entender a construção social da Identidade, faz-se necessário entender que o primeiro momento de sua constituição se faz no processo de socialização primária. Os elementos básicos para a socialização passados pela família são o início da compreensão da realidade social que foi objetivada, institucionalizada e reificada (BERGER; LUCKMANN, 1985). A linguagem é um exemplo nítido desse processo, na medida em que os significados semânticos são apreendidos e definidos nesse momento inicial. "A linguagem constrói, então, imensos edifícios de representação simbólica que parecem elevar-se sobre a realidade da vida cotidiana como gigantescas presenças de um outro mundo.” (BERGER; LUCKMANN, 1985, p. 61). Essas construções simbólicas são então assimiladas como realidades objetivas. Entretanto, para que isso aconteça, Berger e Luckmann (1985) salientam que este processo é feito de uma forma carregada de emoções provenientes da relação entre progenitores e filhos.

Nas fases iniciais da socialização a criança é completamente incapaz de distinguir entre a objetividade dos fenômenos naturais e a objetividade das formações sociais. Tomando o aspecto mais importante da socialização, a linguagem aparece à criança como inerente à natureza das coisas, não podendo perceber a noção do caráter convencional dela. (BERGER; LUCKMANN, 1985, p. 85).

O que faz com que o ser humano construa uma realidade social objetivada é a própria necessidade humana de buscar sua estabilidade, que muitas vezes não é possível que seja obtida biologicamente. 


\begin{abstract}
A inerente instabilidade do organismo humano obriga o homem a fornecer a si mesmo um ambiente estável para sua conduta. $\mathrm{O}$ próprio homem tem de especializar e dirigir seus impulsos. Estes fatos biológicos servem de premissas necessárias para a produção da ordem social. Em outras palavras, embora nenhuma ordem social existente possa ser derivada de dados biológicos, a necessidade da ordem social enquanto tal provém do equipamento biológico do homem. (BERGER; LUCKMANN, 1985, p.77).
\end{abstract}

Isso porque o ser humano, para lidar com os processos do cotidiano de sua existência mundana, estabelece hábitos como forma de economia de esforços, liberando-o de tomar decisões a todo o momento. Os hábitos, na medida em que se tornam compartilhados intersubjetivamente, tornam-se um padrão que, na visão de Berger e Luckmann (1985), precedem aos processos de institucionalização. O reconhecimento recíproco, por indivíduos diferentes, dos hábitos cria tipificações que se tornam, ao longo do tempo, elementos objetivados, ou seja, fatos apreendidos como realidade reificada, como se fossem "coisas naturais".

Os processos institucionalizados são então transmitidos de geração a geração como forma de realidade coerente, definindo todo o universo simbólico para as gerações posteriores. $\mathrm{O}$ indivíduo configura-se enquanto sujeito social a partir de uma realidade que foi reificada coletivamente e interiorizada, subjetivamente, pelos indivíduos. A Identidade torna-se fruto, em parte, dos significados daquele universo simbólico específico.

\footnotetext{
Além disso, o mesmo corpo de conhecimento é transmitido à geração seguinte. É aprendido como verdade objetiva no curso da socialização, interiorizando-se assim como realidade subjetiva. Esta realidade por sua vez tem o poder de configurar o indivíduo. Produzirá um tipo específico de pessoa, a saber o caçador, cuja identidade e biografia enquanto caçador têm significação somente num universo constituído pelo mencionado corpo de conhecimento em totalidade (por exemplo, em uma sociedade de caçadores) ou em parte (digamos em nossa própria sociedade, na qual os caçadores se reúnem em um sub-universo próprio). Em outras palavras, nenhuma parte da instituição da caça pode existir sem o particular conhecimento que foi socialmente produzido e objetivado com referência a esta atividade. Caçar e ser caçador implicam a existência em um mundo social definido e controlado por este corpo de conhecimento. Mutatis mutandis, o mesmo se aplica a qualquer área de conduta institucionalizada. (BERGER; LUCKMANN, 1985, p.95).
}

Neste sentido, o que é "ser" brasileiro é, em parte, determinado por aquilo que o indivíduo entende, dentro de seu universo simbólico, como elementos de pertencimento a esta categoria ou de exclusão das categorias diferentes. Reitera-se que estas significações são valorativas e carregadas de emoção, assim como foram, em grade parte, passadas pelos progenitores. Isto será especificamente relevante quando forem contrastados os valores de uma época específica, como as existentes em meados do século XX, e as novas configurações sociais.

A Identidade é, pois, proveniente de relações estreitas com as instituições ou tipificações sociais que foram criadas e vivenciadas pelos indivíduos em um determinado período. 
Finalmente, a própria identidade (o eu total, se preferirmos) pode ser reificada, tanto a do indivíduo quanto a dos outros. Há então uma identificação total do indivíduo com as tipificações que lhe são atribuídas. (BERGER; LUCKMANN, 1985, p.125).

A Identidade, então, passa a ser reforçada e trabalhada na interação do indivíduo com os outros, na medida em que tais relações reforçam as tipificações e recrudescem os valores e significados compartilhados pelo mesmo universo simbólico. O universo simbólico cumpre um papel de perpetuação e legitimação das Identidades. Segundo Berger e Luckmann (1985, p.136) "Desta maneira, o universo simbólico ordena e por isso mesmo legitima os papéis cotidianos, as prioridades e os procedimentos operatórios, colocando-os sub specie universi, isto é, no contexto do quadro de referência mais geral e concebível.”.

Na medida em que os universos simbólicos se modificam, em longo prazo, chocam-se a partir das realidades distintas, sendo que a Identidade é igualmente afetada.

A “sadia" apreensão de si mesmo como possuidor de uma identidade definida, estável e socialmente reconhecida está continuamente ameaçada pelas metamorfoses "supra-realistas" dos sonhos e das fantasias, mesmo se permanece relativamente coerente na interação cotidiana [...] $\mathrm{O}$ aparecimento de outro possível universo simbólico representa uma ameaça porque sua simples existência demonstra empiricamente que o nosso próprio não é inevitável. [...] Sendo produtos históricos da atividade humana, todos os universos socialmente construídos modificam-se, e a transformação é realizada pelas ações concretas dos seres humanos. (BERGER; LUCKMANN, 1985, p. 137,147 e 157$)$.

Desta forma, os autores conectam os elementos da estrutura social bem como os acontecimentos associados a ela diretamente relacionados com a construção da Identidade.

A identidade é evidentemente um elemento-chave da realidade subjetiva, e tal como toda realidade subjetiva, acha-se em relação dialética com a sociedade. A identidade é formada por processos sociais. Uma vez cristalizada, é mantida, modificada ou mesmo remodelada pelas relações sociais. Os processos sociais implicados na formação e conservação da identidade são determinados pela estrutura social. (BERGER; LUCKMANN, 1985, p. 228).

Corroborando a visão de Berger e Luckmann (1985), Giddens (2002) associa a Identidade ao contexto na medida em que considera que são dois pólos de um processo inter-relacionado que se influenciam mutuamente.

As transformações na auto-identidade e a globalização, como quero propor, são os dois pólos da dialética do local e do global nas condições da alta modernidade. Em outras palavras, mudanças em aspectos íntimos da vida pessoal estão diretamente ligadas ao estabelecimento de conexões sociais de grande amplitude. (GIDDENS, 2002, p. 36).

Tendo como ponto de partida a construção social da Identidade, aspectos recentes do contexto revelam a preocupação com o tema, na medida em que as estruturas sociais e as instituições que dela fazem parte passam por um processo de transformação. 


\begin{abstract}
A principal força motora por trás desse processo tem sido desde o princípio a acelerada "liquefação" das estruturas e instituições sociais. Estamos agora passando da fase "sólida" da modernidade para a fase "fluida". E os "fluidos" são assim chamados porque não conseguem manter a forma por muito tempo e, a menos que sejam derramados num recipiente apertado, continuam mudando de forma sob a influência até mesmo das menores forças. Num ambiente fluido, não há como saber se o que nos espera é uma enchente ou uma seca - é melhor estar preparado para as duas possibilidades. Não se deve esperar que as estruturas, quando (se) disponíveis, durem muito tempo. (BAUMAN, 2005, p. 57).
\end{abstract}

Desta forma, entende-se que a Identidade não é fixa e possui componentes relacionados às Instituições sociais que propiciam tal mobilidade. Entretanto, ela não muda ao sabor dos ventos, a qualquer pequena alteração. É preciso que o universo simbólico se reposicione como diferente e que as instituições sociais passem por processos de transformação.

\title{
2.1.6. A perspectiva construcionista e Identidade Social
}

Implicitamente, ao se tratar da Identidade como construção social, está-se delimitando o tratamento do conceito dentro de uma perspectiva construcionista. Spink e Frezza (1999, p.23) esclarecem que

A perspectiva construcionista é resultante de três movimentos: na Filosofia, como uma reação ao
representacionismo; na Sociologia do Conhecimento, como forma de desconstrução da retórica da
verdade, e na Política, como busca de empowerment de grupos socialmente marginalizados.

As autoras, balizando-se nos trabalhos de Tomás Ibáñez, descrevem que dentre as questões epistemológicas, como reação ao representacionismo, o construcionismo procura desfazer a crença da dualidade sujeito-objeto comuns nas abordagens empiristas, racionalistas e interacionalistas (SPINK; FrEZZA, 1999). Na abordagem representacionista, sujeito e objeto são sempre entendidos como ontologicamente separados, e o conhecimento é uma representação ou tradução de algo que é externo ao sujeito.

Diferentemente, o construcionismo entende que tanto o sujeito quanto o objeto são construções sócio-históricas, que só podem se entendidas como produtos das interações humanas em contexto determinado. Neste sentido, o conhecimento não é uma representação da realidade externa ao indivíduo. O próprio indivíduo é uma construção social.

Spink e Frezza (1999) também retomam os conceitos de Berger e Luckmann (1985), da Sociologia do Conhecimento, que buscam relativizar o conceito de verdade. Reiteram que a sociedade é um produto humano, ou seja, construída socialmente.

No cotidiano de nossas vidas, somos, de fato, produtos de nossa época e não escapamos das convenções, das ordens morais e das estruturas de legitimação. A pesquisa construcionista é, 
portanto, um convite a examinar essas convenções e entendê-las como regras socialmente construídas e historicamente localizadas. (SPINK; FREZZA, 1999, p.32).

Citando Kenneth Gergen como um dos primeiros psicólogos sociais a trabalhar dentro da perspectiva construcionista, Spink e Frezza (1999, p.26) reproduzem o autor: “A investigação sócio-construcionista preocupa-se sobretudo com a explicação dos processos por meio dos quais as pessoas descrevem, explicam ou dão conta do mundo (incluindo a si mesmos) em que vivem" (GERGEN, 1985, p. 266) (Grifo nosso).

Dentro da abordagem construcionista, a Identidade passa a ser entendida como uma construção que o indivíduo faz em suas práticas sociais. Ao lidar com a realidade, o indivíduo se constrói. Ao procurar dar respostas de si mesmos, os sujeitos constroem quem são.

Outro ponto importante da abordagem construcionista diz respeito às práticas discursivas. Elas se tornam elemento central de compreensão tanto da realidade quanto do sujeito. Ao construir seu discurso, nos processos de interação social, o indivíduo reconstrói sua realidade, afirmando-a ou negando-a, bem como se reconstrói, negando-se ou afirmando-se.

De forma análoga, Maturana e Varela (1995), ao criticarem o representacionismo pela dicotomia sujeito-objeto, afirmam que todos os seres vivos são autopoiéticos, pois se autocontroem. São produtos de si mesmos, "Donde se conclui que não há separação entre produtor e produto" (MATURANA; VARELA, 1995, p.57). A linguagem é novamente enfatizada como elemento importante para o conhecer humano.

Toda reflexão, inclusive a que se faz sobre os fundamentos do conhecer humano, ocorre necessariamente na linguagem, que é nossa maneira particular de ser humanos e estar no fazer humano. Por isso, a linguagem é também nosso ponto de partida, nosso instrumento cognitivo e nosso problema. (MATURANA; VARELA, 1995, p.32).

Os autores acrescentam ainda:

Realizamos a nós mesmos em mútuo acoplamento lingüístico, não porque a linguagem nos permita dizer o que somos, mas porque somos na linguagem, em um contínuo existir nos mundos lingüísticos e semânticos que produzimos com os outros. Encontramos a nós mesmos nesse acoplamento [...] em contínua transformação no vir-a-ser do mundo lingüístico que construímos com os outros seres humanos. (MATURANA; VARELA, 1995, p.252) (Grifo nosso).

O discurso que o indivíduo constrói sobre si mesmo e sobre sua realidade é elemento central na análise tanto do sujeito quanto do objeto. Tais definições sobre a abordagem construcionista são especialmente relevantes nas opções metodológicas que foram feitas neste estudo. 


\subsubsection{Identidade Social dentro do espaço organizacional}

A Identidade Social é entendida como parte da Identidade Pessoal de um indivíduo. O que a define, é o fato de ser construída socialmente a partir das relações e interações que acontecem no escopo da vida social do Indivíduo.

Analisando a partir de uma outra concepção, Machado (2003) detalha que no espaço organizacional é possível detectar quatro campos de análise em termos de Identidade: a Identidade Pessoal, a Identidade Social, a Identidade no Trabalho e a Identidade Organizacional. A Identidade Pessoal é uma construção psicológica que tenta dar uma explicação do conceito de si para o indivíduo. A Identidade Social é uma representação de si por pertencer a um grupo ou coletivo. A Identidade no Trabalho é uma construção a partir dos papéis que o indivíduo desempenha no ambiente laboral. A Identidade Organizacional não está no indivíduo, mas na entidade à qual ele pertence e sente que faz parte. Para a autora essas Identidades se interferem mutuamente na constituição do ser social.

De forma distinta da visão dessa autora, nesta pesquisa entende-se Identidade Social no seu sentido amplo, sendo que essa concepção parte da premissa de que o Trabalho, a Organização e o Grupo, são faces da Identidade Social. Entretanto, o trabalho de Machado (2003) é importante porque mostra esferas relevantes a serem consideradas no estudo da Identidade Social associadas ao espaço laboral: o outro e as relações sociais, a organização - e a relação do indivíduo com ela - e o trabalho em si.

É difícil dimensionar o quanto as organizações influenciam nas constituições das Identidades no contexto atual. Entretanto, a compreensão de que vivemos em uma Sociedade Organizacional dimensiona parte dessa questão. Por Sociedade Organizacional, entende-se que as esferas públicas e privadas dos indivíduos são, em grande parte, mediadas pelas organizações de tal maneira que seria difícil pensar nossa sociedade desprovida desse tipo de entidade.

Sob duas perspectivas diferentes, que não são as únicas, as organizações interferem no cotidiano das relações sociais dos indivíduos. A primeira ótica é a do indivíduo como trabalhador, na medida em que ele se insere em organizações para se tornar economicamente ativo e ter acesso a recursos para sua sobrevivência. Em outras palavras, o indivíduo precisa trabalhar e como não dispõe de outra forma de acesso à sobrevivência, ele se insere dentro do 
contexto do trabalho em organizações, dadas as características de nossa sociedade, que requer, pelo menos para uma grande maioria, que se submeta à divisão social do trabalho. Fazer parte da organização é estar submetido a uma série de regras e políticas organizacionais que interferirão no seu cotidiano.

Independentemente de suas histórias individuais e seu passado, os atores sociais passam muito
tempo no ambiente de trabalho. O fato de possuírem as mesmas condições de trabalho e os
mesmos espaços de interação, bem como o acesso e o controle do mesmo tipo de recursos, oferece
aos indivíduos caminhos similares de acesso à identidade e ao entendimento. (VASCONCELOS;
VASCONCELOS, 2002, p. 68).

Em um segundo prisma de análise, o indivíduo - também em função da divisão social do trabalho - depende, em grande parte, de organizações como fonte para obter acesso aos produtos e serviços dos quais precisa para sua vivência mundana. Esses dois aspectos são separados em função de uma opção de construção de nossa sociedade, de forma que o processo de produzir pode ser, para um indivíduo específico, distante do processo de consumir. Nem sempre o que ele produz, é consumido por ele e vice-versa. Essa dissociação acontece não só pela divisão social do trabalho, como também pelos aspectos econômicos e financeiros associados ao nosso modelo de organização social.

Tendo como perspectiva de análise esta dupla interface das organizações sobre os indivíduos, uma vez que são elas que fazem a mediação entre o trabalho e o consumo, percebe-se que há uma forte influência destas entidades sobre o cotidiano das relações sociais. Morgan (1996) relata essa influência das organizações sobre os indivíduos e a dicotomia que se estabelece entre aquele que trabalha e aquele que usufrui das organizações. As organizações para esse autor são vistas como influenciadoras da vida social, muitas vezes como instrumentos de dominação social e da vida íntima, na medida em que definem aspectos políticos das relações sociais no trabalho. Isso porque as formas de gestão e organização do trabalho interferem diretamente sobre o espaço micro-social das empresas.

Vasconcelos e Vasconcelos (2002) afirmam que as formas que as políticas de recursos humanos assumem estão diretamente relacionadas à construção da Identidade Social dentro das empresas, sendo que as organizações podem assumir posições políticas, no que diz respeito ao conflito e à pluralidade, que interferem diretamente nos trabalhadores.

Existem modelos de Gestão de Recursos Humanos (GRH) que propõem o desenvolvimento político e cognitivo dos atores sociais nas organizações e incorporam as dimensões do conflito e do debate, favorecendo a emergência de identidades do tipo "solidariedade democrática" e "afinidades seletivas" anteriormente descritas. Outros modelos sugerem práticas opostas, que, ao 
reduzirem a autonomia dos atores organizacionais, limitam o seu desenvolvimento cognitivo e politização. (VASCONCELOS; VASCONCELOS, 2002, p. 70).

Ressalta-se que as organizações representam um espaço social como outro qualquer, embora tenham suas características e especificidades. Como tal, as organizações mediam relações sociais entre atores sociais e possuem seus universos simbólicos e culturais específicos. São nestes universos simbólicos intra-organizacionais que as Identidades são, em parte, afetadas. Entretanto, não se pode esquecer que as organizações sempre estão diretamente ligadas ao contexto social. As mudanças e transformações sociais geram impactos nos modelos de gestão e nas políticas de recursos humanos (AlBUQUERQUe, 2002), lembrando que tais políticas fazem a interface entre os aspectos da sociedade e o quadro interno das organizações (FISCHER, 1985).

\subsubsection{Identidade Social e trabalho}

Especificamente no trabalho, a Identidade Social ganha uma dimensão importante, porque esta atividade constitui, para alguns autores, um dos principais elementos que norteiam a vida social do indivíduo. Uma vez que o próprio trabalho se modifica tecnológica, gerencial e socialmente ao longo do tempo, a própria Identidade Social se transforma e, por isso, precisa ser melhor compreendida em novos contextos.

É necessário entender que o trabalho constitui, para o homem, elemento construtor de sua humanidade e vida (ENRIQUEZ, 1999; ARENDT, 2004).

Ao definir o trabalho como "o metabolismo do homem com a natureza", em cujo processo "o material da natureza (é) adaptado, por uma mudança de forma, às necessidades do homem", de sorte que "o trabalho se incorpora ao sujeito", Marx deixou claro que estava "falando fisiologicamente", e que o trabalho e o consumo são apenas dois estágios do eterno ciclo da vida biológica. (ARENDT, 2004, p. 110).

Antunes (1995, p. 121) também afirma: que “[...] o ato de produção e reprodução da vida humana realiza-se pelo trabalho. É a partir do trabalho, em sua cotidianidade, que o homem torna-se ser social, distinguindo-se de todas as formas não humanas." Com isto, Antunes (1995) quer dizer que o homem deixa de ser submisso à natureza e passa a transformá-la e subordiná-la aos seus interesses. Ou seja, o trabalho, uma vez que representa a relação entre a natureza e o metabolismo humano, é essencial para a existência do ser. Entretanto, o significado da atividade humana por meio do trabalho possui conotações diferenciadas nos diversos períodos históricos. 
Arendt (2004), discorrendo sobre o trabalho e o labor, desvela, valendo-se das concepções da Grécia Antiga, que "Laborar significava ser escravizado pela necessidade, escravidão esta inerente às condições da vida humana”. Arendt (2004) está chamando a atenção para o fato de que a concepção assumida neste caso é de que, enquanto o homem depender do labor para suprir suas necessidades, o ser humano não será plenamente livre. Enriquez (1999) complementa esta visão dizendo que:

Nas antigas sociedades, particularmente naquela que, para nós, é sempre uma sociedade de
referência - a sociedade grega, da Atenas do século V a.c. - o trabalho não era absolutamente
valorizado. Vocês sabem muito bem que, logo após, os romanos chamariam o trabalho de
tripalium, que era um instrumento de tortura. Assim, o trabalho era fundamentalmente "aquilo
que tortura". Além disso, como diziam particularmente Platão e Aristóteles, o trabalho é aquilo
que está ligado à necessidade de se cobrir, de se alimentar etc. Então, para os gregos antigos, tudo
aquilo que está ligado à necessidade não define a liberdade nem a grandeza do homem.
(ENRIQUEZ, 1999, p. 70).

É interessante resgatar a visão de Hall (1999) que descreve que, no período helênico, a Identidade era considerada como uma essência, imutável, estabilizada e fixa. No que diz respeito ao trabalho neste período, a Identidade está vinculada à sua ocupação social também, sendo que os escravos é que deveriam trabalhar para que seus senhores, cidadãos helênicos, tivessem a condição de serem livres - inclusive do labor humano.

Essa consideração é importante para entendermos que as conotações valorativas do trabalho se alteraram a partir da consolidação do capitalismo. Arendt (2004) entende que as transformações da Era Moderna, em parte impulsionadas pelos valores do cristianismo, fizeram com que uma total inversão de valores fosse feita, "tendo glorificado o trabalho (labor) como fonte de todos os valores." (ARENDT, 2004, p. 96).

Enriquez (1999) detalha que nesta inversão, o sentido do trabalho é agora associado à liberdade individual, na medida em que se contestam os valores do feudalismo, quando o sujeito era servo e preso à terra. Essa liberdade, entretanto, serve apenas para "vender sua força de trabalho a quem possa lhe dar emprego.” (ENRIQUEZ, 1999, p. 71).

O trabalho passa então a ser elemento fundamental e constituidor da personalidade de operários, formando a consciência profissional (ENRIQUEZ, 1999). Ressalta-se que o trabalhador começa a se configurar a partir de uma série de definições econômicas, políticas e sociais provenientes de sua atividade. Na Inglaterra da Revolução Industrial, a Poor Law, ou lei dos pobres, retirava a cidadania dos que estivessem excluídos do mundo do trabalho como condição para ter direito às práticas assistencialistas. O salário definia uma classe econômica 
específica e, em grande parte, imutável.

[...] o trabalho que era tão desvalorizado nas sociedades antigas, torna-se um elemento fundamentalmente integrador da sociedade, isto é, permite efetivamente a uma sociedade engendrar ou reforçar laços sociais. A figura do trabalhador vai se tornar totalmente central. (ENRIQUEZ, 1999, p. 72).

Esses aspectos da construção do sujeito social da Era Moderna foram importantes para a constituição de uma Identidade Social vinculada ao trabalho. Percebe-se como a era das indústrias foi um marco nesse processo.

Em parte, esses valores, muito presentes ainda no nosso contexto, podem ser nitidamente apreendidos quando o sujeito social se depara com a situação de exclusão do trabalho. Caldas (1999), ao estudar a demissão e a perda do emprego e o que isto significa em termos psicológicos, discorre:

$\mathrm{Na}$ medida em que às vezes construímos o que somos através de $o$ que fazemos, a perda do emprego pode significar o sentimento de "dissolução" ou "mutilação" de aspectos elementares do nosso eu. [...] Em outros depoimentos, a noção de perda ou vazio associada ao desemprego é expressa em termos mais elementares e profundos, expressando a idéia de perda ou dissolução da identidade. (CALDAS, 1999, p. 7-8).

Caldas (1999) acrescenta ainda que as organizações também são um referencial para os indivíduos, uma vez que é a partir delas que se tem acesso ao trabalho.

[...] o problema é que nos dias de hoje boa parte dos significados que construímos - sobre o mundo e nós mesmos - tem uma organização ou um papel organizacional como referencial. Ou seja, quando perguntamos quem é uma pessoa, a resposta mais esperada contém tanto um papel quanto uma organização como referências: "ele é um engenheiro da Petrobrás", "Lea era uma vendedora da Mesbla". De forma semelhante, uma profissão pode dar às pessoas uma identidade mais central ainda do que aquela associada a um emprego específico: por exemplo, o indivíduo pode ser um cirurgião, ou um mecânico, ou um dentista. (CALDAS, 1999, p. 8).

Enriquez (1999) também vê a perda do trabalho como algo que afeta a Identidade, na medida em que é um dos elementos que constituem o ser.

Sabemos muito bem que toda perda de trabalho provoca uma ferida profunda na identidade de diferentes pessoas, concorrendo para a degradação de suas personalidades. [...] estamos todos de acordo em dizer que o trabalho é um dos elementos constitutivos do ser humano. (ENRIQUEZ, 1999, p. 69).

Outro aspecto importante da formação da Identidade a partir do trabalho é a constituição de profissões específicas, que, na visão de Gaulejac (2002), também são formas de um pertencimento a um coletivo.

Da mesma forma, as identidades profissionais produzem sentimentos de pertencimento a coletivos 
que reúnem todas as pessoas que se graduaram nos mesmos cursos, que têm diplomas equivalentes, que exercem ofícios similares, ou que ocupam as mesmas funções. Uma pessoa pode definir-se como operário, agricultor, executivo, padeiro, médico, técnico, jurista, professor..., tantas definições de si mesmo que servem de embasamento ao reconhecimento social. (GAULEJAC, 2002, p. 176)(Tradução nossa) ${ }^{6}$.

Ou seja, é possível detectar que a Identidade Social associada ao trabalho pode-se manifestar através do pertencimento e exclusão (diferenciação) em termos de uma classe (ENRIQUEZ, 1999) uma organização (CALDAS, 1999; MACHADO, 2003), uma profissão (CALDAS, 1999; GAULEJAC, 2002) e a execução de uma atividade ou processo de trabalho (CIAMPA, 2005).

Uma vez que o trabalho é entendido como constituidor de Identidade Social, principalmente sob a égide da Era Moderna, passa-se a discutir os aspectos da transformação do contexto e do trabalho, entendendo que isto está diretamente relacionado à construção da Identidade Social.

\subsection{AS TRANSFORMAÇÕES DO TRABALHO E A IDENTIDADE SOCIAL.}

Retomando a questão das metamorfoses sociais, o trabalho e as organizações são, particularmente, o espaço onde grande parte das mudanças se concretiza, principalmente por meio da tecnologia e das novas formas de gestão. É também na organização e no trabalho o lugar em que a imposição ao indivíduo desses novos valores e mudanças são mais fortes, considerando as relações de trabalho desiguais e um aparato técnico-ideológico calcado na "necessidade" de competitividade e modernidade (SANTOS, 2002).

Como salientado por Hall (1999) e por Bauman (2005), o trabalho se constituiu, no auge da Era Moderna como a grande referência identitária, na medida em que as classes sociais foram se definindo. A construção de classes sociais definiu concomitantemente o pertencimento a uma classe trabalhadora específica e o pertencimento a uma classe de acesso aos bens de

\footnotetext{
6 "De même, les identités professionnelles produisent des sentiments d'appartenance à des colletifs que rassemblent tous ceux que ont suivi les mêmes études, passé des diplômes équivalents, que exercent des métiers similaires ou qui occupent les même fonctions. On peut ainsi se définir comme ouvrier, agriculteur, cadre, boulanger, médecin, polytechnicien, juriste, instituteur..., autant de définitions de soi que servent de soubassement à la reconnaissance sociale."
} 
consumo determinados.

Houve um tempo em que a identidade humana de uma pessoa era determinada fundamentalmente pelo papel produtivo desempenhado na divisão social do trabalho, quando o Estado garantia (se não na prática, ao menos nas intenções e promessas) a solidez e a durabilidade desse papel, e quando os sujeitos do Estado podiam exigir que as autoridades prestassem contas no caso de deixarem de cumprir as suas promessas e desincumbir-se da responsabilidade assumida de proporcionar a plena satisfação dos cidadãos. (BAUMAN, 2005, p.51-52).

Neste sentido, a classe servia como uma unidade estável e coerente para as Identidades, na medida em que isto significava também uma coerência entre as dicotomias existentes na esfera política, econômica e social. De um lado ficava uma classe trabalhadora, operária, menos abastada e de tendências esquerdistas e de outro uma classe de proprietários, burguesa, em boa situação econômica e com tendências de direita. Sabe-se que a realidade é por demais complexa para que estas representações se encaixem perfeitamente na realidade dos indivíduos, mas dentro das concepções do universo simbólico vigente, isto se configurava como coerente para servir como referência identitária.

$\mathrm{Na}$ medida em que a modernidade recrudesce seus valores e a realidade se mostra mais complexa do que o enquadramento feito pelas tipificações, a classe como elemento estruturador de uma Identidade começa a perder a legitimação necessária à sua reificação (Berger; Luckmann, 1985; Hall, 1999; Bauman, 2005). Hall (1999), como salientado anteriormente, descreve que novos referenciais estão surgindo como pontos de ancoragem para as Identidades tais como movimentos feministas, reafirmações étnicas, dentre outros. Bauman (2005) corrobora tais afirmações, afirmando que:

\footnotetext{
Novas bandeiras foram costuradas e erguidas, novos manifestos elaborados, novos cartazes concebidos e impressos. Como a classe não mais oferecia um lugar seguro para reivindicações discrepantes e difusas, o descontentamento social dissolveu-se num número indefinido de ressentimentos de grupos ou categorias, cada qual procurando a sua própria âncora social. (BAUMAN, 2005, p. 42).
}

Deve-se ter em mente que o trabalho passou por transformações significativas ao longo século passado, em plena Era Moderna. Dentre as principais transformações relatadas pelos autores, temos o crescimento do setor de serviços - que difere em grande parte das características do setor industrial tradicional - a mão-de-obra se torna mais heterogênea com a crescente inclusão da força de trabalho feminina, as transformações tecnológicas como a informatização e a automação, o enfraquecimento político de categorias profissionais específicas (CHILD, 1991; Antunes, 1995; VAlle, 1995; DedecCA, 1996; FAlqueto, 1997). 
Esta constatação de que o trabalho e, conseqüentemente a classe, estariam deixando de ser referência social foi alvo de debate por Gorz (1982) e Offe (1989), sendo que estes autores estavam questionando a centralidade do trabalho como categoria chave de análise social.

Como resultado de uma redução nos postos de trabalho na indústria, resultado da implantação de
novas tecnologias, Gorz previu que uma redução na classe operária levaria a uma alteração no
conteúdo político e ideológico do trabalho. A questão que se debate, então, é exatamente esta: a
redução da classe proletária industrial traria uma perda de referência e relevância do ser que
trabalha? (VELOSo et al., 1999, p. 64).

Para Offe (1989), o trabalho perde sua referência como elemento central na sociedade na medida em que sofre uma série de transformações políticas, econômicas e sociais. Outras esferas da vida do indivíduo estariam se cristalizando como pontos de referência, preenchendo as lacunas deixadas pelo trabalho.

É interessante ressaltar que a classe trabalhadora é enfocada por estes autores (GoRZ, 1982; OFFE, 1989; ANTUNES, 1995) como sofrendo um processo de grandes mudanças e tornando-se mais complexa. Não se pode pensar o trabalhador do contexto atual como se fosse o mesmo de outrora. A começar pelo crescimento do setor de serviços que não possui as mesmas características do setor industrial do auge do fordismo. Há igualmente dados estatísticos comprovando a queda do percentual de participação do operariado industrial na composição do mercado de trabalho. Outro ponto relatado pelos autores é a automação no setor industrial que faz com que as características do trabalho executado sejam marcantemente diferentes. A composição da mão-de-obra também é descrita como alvo de mudanças significativas. A inserção da mão-de-obra feminina em espaços de trabalho tradicionalmente ocupados por homens faz com que se tenha um novo perfil da classe de trabalhadores. Além disso, acrescenta-se o crescimento do trabalho informal, bem como formas precarizadas de trabalho, tais como terceirização e, em alguns casos, a formação das cooperativas.

Antunes (1995) analisa os mesmos sinais descritos por estes dois autores, mas discorda das conclusões, sendo que, para ele, o trabalho continua como elemento central, dadas as características de nossa sociedade, que ainda depende da produção e do consumo. Entretanto, para Antunes (1995), a relação do indivíduo com o trabalho passa por um processo de "estranhamento". Independente das análises feitas e conclusões, seja ou não, o trabalho, o elemento central da sociedade, percebe-se que a relação do indivíduo com o trabalho passa por um processo de transformação dos valores e significados simbólicos. 
Linhart (1991) também vê que a questão das transformações afeta a sociedade e o trabalho, em função de uma crise pela qual passa, interferindo no indivíduo e na constituição do seu "ser".

\begin{abstract}
Alguns autores expõem a Idéia de que a crise e o desemprego crescente favorecem a aparição de novos modos de vida, de uma sociedade "com mais convívio", baseada em outros valores além do trabalho.
\end{abstract}

As análises que acabamos de expor induzem a pensar que por hora, a crise e o desemprego atropelam, golpeiam violentamente os trabalhadores em seu ser, em seu equilíbrio. (LINHART, 1991, p.538) (Grifo nosso) (Tradução nossa). ${ }^{7}$

Para Sennet (2004), as transformações que o trabalho tem sofrido são provenientes da mudança na lógica como as organizações têm se redefinido perante o contexto de competitividade atual. Ou seja, elementos contextuais têm impulsionado freqüentes mudanças nas organizações que geram alterações na estrutura interna e, conseqüentemente, na forma como o trabalho é executado. Nas palavras de Sennet (2004, p. 60), "O ingrediente de mais forte sabor nesse novo processo produtivo é a disposição de deixar que as mutantes demandas do mundo externo determinem a estrutura interna das instituições." Para este autor, a extrema valorização da mudança e da flexibilidade como valores organizacionais para a competitividade, servem de norte para a relação do indivíduo com o trabalho e, por isso, geram uma destruição de elementos referenciais para os indivíduos. Tais referenciais serviam, na visão de Sennet (2004), como norteadores para a construção de um caráter e que isto afeta a sustentabilidade da Identidade.

Como se podem buscar objetivos de longo prazo numa sociedade de curto prazo? Como se podem manter relações sociais duráveis? Como pode um ser humano desenvolver uma narrativa de identidade e história de vida numa sociedade composta de episódios e fragmentos? As condições da nova economia alimentam, ao contrário, a experiência com a deriva no tempo, de lugar em lugar, de emprego em emprego. Se eu fosse explicar mais amplamente o dilema de Rico, diria que o capitalismo de curto prazo corrói o caráter dele, sobretudo aquelas qualidades de caráter que

7 “Algunos autores exponen la Idea de que la crisis y el desempleo crecientes favorecen la aparición de nuevos modos de vida, de una sociedad "más convival”, basada en otros valores además del trabajo.

Los análisis que acabamos de exponer inducen a pensar que por ahora, la crisis y el desempleo atropellan, golpean violentamente a los trabajadores en su ser, en su equilibrio." 
ligam os seres humanos uns aos outros, e dão a cada um deles um senso de identidade sustentável. (SENNETT, 2004, p. 27).

Sennet (2004) complementa seus argumentos associando a flexibilidade e a fluidez das Identidades como fontes de impacto no compromisso que o indivíduo tem com seu trabalho, mostrando uma relação superficial que o indivíduo estabelece com sua atividade.

É um lugar-comum dizer que as identidades modernas são mais fluidas que as divisões categóricas
das pessoas nas sociedades submetidas a classes do passado. "Fluido" pode querer dizer adaptável.
Mas em outra cadeia de associações, também significa descontração; o movimento fluido exige
que não haja impedimentos. Quando tudo nos é facilitado, como no trabalho que descrevi,
tornamo-nos fracos; nosso compromisso como o trabalho se torna superficial, uma vez que não
entendemos o que fazemos. (SENNET, 2004, p.87-88).

Interessante reparar como o autor destaca que as pessoas não querem que o trabalho se torne algo inerente à sua individualidade. A frieza e o profissionalismo parecem querer impermeabilizar o indivíduo perante sua situação de trabalho. É como uma busca pelo isolamento de sua Identidade no trabalho.

Sennet (2004) atribui à revolução tecnológica parte das transformações ocorridas no trabalho. Segundo o autor "Os ingredientes necessários para a especialização flexível, também aqui, nos são conhecidos. A especialização flexível serve à alta tecnologia; graças ao computador, é fácil reprogramar e configurar máquinas industriais.” (SENNET, 2004, p. 60). Mas é interessante ver que Sennet associa tais mudanças diretamente ao papel valorizado que o consumidor tem neste contexto. Na medida em que esta figura é sobrevalorizada, as mudanças organizacionais se legitimam na busca de atender a uma entidade que parece estar socialmente em patamar superior.

Mas há motivos mais fundamentais por trás do moderno capitalismo para buscar uma mudança decisiva, irreversível, por mais desorganizada ou improdutiva que seja. Referem-se à volatilidade da demanda do consumidor. Essa volatilidade produz uma segunda característica dos regimes flexíveis, a especialização flexível. (SENNET, 2004, p.59).

Bauman (2005) retoma e corrobora a visão de Sennet, fazendo uma interligação com o trabalho de Bourdieu, denotando que as pessoas passam de uns referenciais a outros, todos de curta duração, e que isso recrudesce a fragmentação das Identidades.

Pierre Bourdieu e Richard Sennett explicaram por que o esfacelamento de cenários e rotinas anteriormente estáveis e a fragilidade recém-revelada até mesmo por empresas grandes e aparentemente sólidas não favorecem uma postura de união e solidariedade, além de evitar que problemas e ansiedades individuais se intensifiquem no conflito de classes. Como nos mostram Boltanski e Chiapello, os empregados se viram numa cite par projets, onde as perspectivas de emprego são confinadas a um único projeto atualmente em andamento. Entre as pessoas que vivem de um projeto para outro, pessoas cujos processos de vida são desmembrados numa sucessão de 
projetos de curta duração, não há tempo para que descontentamentos difusos se reduzam à busca por um mundo melhor... Tais pessoas prefeririam um hoje diferente para cada um a pensarem seriamente num futuro melhor para todos. Em meio ao esforço diário apenas para se manter à tona, não há espaço nem tempo para uma visão da "boa sociedade". (BAUMAN, 2005, p. 41).

Neste sentido, Bauman (2005) entende que as fábricas não são mais um local que dê segurança às Identidades, em função da extrema volatilidade e fragmentação das rotinas do trabalho.

\subsection{CONSUMO E TRABAlHo}

É interessante perceber que o consumo e o trabalho, embora muitas vezes tratados como elementos distintos pelas pesquisas ou discussões, são faces do mesmo processo. O fato de que, na era industrial, esses elementos fossem tratados como separados e distanciados criou uma forma de trabalho distanciado das necessidades humanas em termos da produtividade. Ao mesmo tempo, criou-se uma distância entre as necessidades reais do indivíduo e aquilo que ele realmente consome.

Arendt (2004) comenta que o ato de produzir e consumir, na sua forma original, isso é, na sua concepção essencial, estão ligados diretamente, de forma que o labor humano (aqui entendido como produção de bens de consumo) é consumido ou metabolizado pelo indivíduo ou pela natureza, dada a sua efemeridade. O trabalho, diferentemente do labor, produz bens de uso, cuja perenidade transcende a necessidade imediata e metabólica do ser humano.

A partir de uma reconstrução dos valores na Era Moderna, o trabalho humano passa a gerar excedentes de produção além da necessidade existencial do homem. Isto porque, segundo Arendt (2004), a mesclagem que se fez ao longo da Era Moderna dos conceitos labor e trabalho fez com que consumo e a produção se distanciassem das necessidades que deveriam atender. A partir daí, o homem produz bens de uso como se fossem bens de consumo. Tal qual como são produzidos, são consumidos.

\footnotetext{
Consiste em tratar os objetos de uso como se fossem bens de consumo, de sorte que uma cadeira ou mesa seriam consumidas tão rapidamente quanto um vestido, e um vestido quase tão rapidamente quanto um alimento. Esta forma de tratar as coisas do mundo é perfeitamente adequada ao modo como elas são produzidas. A revolução industrial substituiu todo artesanato pelo labor; o resultado foi que as coisas do mundo moderno se tornaram produtos do labor, cujo destino natural é serem consumidos, ao invés de produtos do trabalho, que se destinam a ser usados. (ARENDT, 2004, p. 137).
}

Baudrillard (1991) explora a simbologia que envolve a sociedade de consumo, procurando expor os seus elementos constitutivos. Como um dos pontos de reflexão, o autor diz que 
objetos, produtos e bens de consumo, estão se multiplicando, numa clara demonstração de abundância.

\footnotetext{
À nossa volta, existe hoje uma espécie de evidência fantástica do consumo e da abundância, criada pela multiplicação dos objectos, dos serviços, dos bens materiais, originando como que uma categoria de mutação fundamental na ecologia da espécie humana. (BAUDRILLARD, 1991, p. 15).
}

Segundo Baudrillard (1991), os objetos são pontos de referência social nos quais o indivíduo procura um status em relação aos demais. É uma forma de diferenciação, de procurar se sobressair em relação aos demais. A busca pela felicidade neste tipo de construção se dá pela possibilidade de consumo destes bens que não são acessíveis a todos.

Destaca-se que o autor denota o fato de que os signos e os valores são de certa forma construídos de tal maneira que "[...] se enreda uma ordem do consumo, que se manifesta como ordem da manipulação dos signos[...]" (BAUdRILlard, 1991, p. 23). Com pensamento semelhante ao de Baudrillard (1991), Santos (2002) afirma que as organizações também são as responsáveis por produzir os consumidores muito antes de confeccionar os produtos para eles. Ou seja, a organização constrói o consumo e os valores a ele ligados no ideário do sujeito social. De forma análoga, Giddens (2002, p. 182) expõe:

\begin{abstract}
Além disso, a mercantilização afeta crucialmente a força de trabalho - de fato a força de trabalho como tal só passa a existir quando separada, como mercadoria, do "trabalho" como um todo. Finalmente, a mercantilização afeta diretamente os processos de consumo, particularmente com o amadurecimento da ordem capitalista. O estabelecimento de padrões regulares de consumo, promovidos pela propaganda e outros métodos, torna-se central para o crescimento econômico. Em todos esses sentidos, a mercantilização influencia o projeto do eu e o estabelecimento dos estilos de vida.
\end{abstract}

Baudrillard (1991) vai diferenciar a sua concepção de consumo da visão que Arendt (2004) tem, uma vez que vai rejeitar a idéia de que o consumo é uma busca pela satisfação das necessidades humanas. A idéia de que consumimos em função de nossas necessidades físicas é suplantada pelo consumo como uma forma de distinção social, de busca pelo status e, portanto, insaciável. Nesse sentido, as desigualdades sociais não são problema para a sociedade de consumo, pelo contrário, são utilizadas como propulsores econômicos desta sociedade.

Neste tipo de sociedade, dissemina-se que os objetos podem proporcionar a felicidade que não pode ser obtida em outras esferas da vida. E esse discurso está incorporado ao cotidiano organizacional, trazido tanto pelas regras produtivas quanto pelos próprios trabalhadores uma vez que também se inserem no sistema de consumo. Passa-se a constante idéia de que o 
consumidor tem o direito de ser tratado de forma reverenciada, nesse sistema. $\mathrm{O}$ discurso da organização de sobrevalorização do consumidor é difundido sistematicamente, tanto pelos meios de comunicação e propaganda, quanto pelas políticas internas das organizações, através dos programas de qualidade em produtos e serviços. Ressalta-se, entretanto, que a promessa de felicidade na sociedade de consumo é ilusória, pois nunca será atingida, uma vez que os indivíduos procuram a diferenciação e o status. Para que uns sejam felizes, é preciso ter o que os outros não têm, gerando a desigualdade e a construção de categorias em possuidores e nãopossuidores de bens (BAUDRILLARD, 1991).

Toda a publicidade carece de sentido; só tem significações. No entanto, tais significações (e as condutas a que elas se referem) nunca são pessoais; mas diferenciais, marginais e combinatórias. Isto é, dependem da produção industrial das diferenças - pelas quais - na minha opinião - se definiria com maior força o sistema do consumo. (BAUDRILLARD, 1991, p.88).

Sennet (2004) também destaca o consumo como força motriz do capitalismo. Nas palavras do autor: "Como história econômica, A ética protestante e o espírito do capitalismo está eivado de erros. Como análise econômica, omite estranhamente qualquer consideração do consumo como força motivadora no capitalismo.” (SENNET, 2004, p.126).

Para Bauman (2005), cada vez mais os processos de socialização estão mudando o foco de importância do ser social do trabalho para o consumo.

Se os nossos ancestrais eram moldados e treinados por suas sociedades como, acima de tudo, produtores, somos cada vez mais moldados e treinados como, acima de tudo, consumidores, todo resto vindo depois. Atributos considerados trunfos num produtor (aquisição e retenção de hábitos, lealdade aos costumes estabelecidos, tolerância à rotina e a padrões de comportamento repetitivos, boa vontade em adiar a satisfação, rigidez de necessidades) se transformam nos vícios mais apavorantes no caso de um consumidor. Se permanecessem ou no caso se tornassem comuns, seriam como o dobre de finados da economia centrada no consumidor. (BAUMAN, 2005, p. 72- 73).

Bauman (2005), de uma forma radical, enfatiza que o modo consumista cria Identidades e as deixa expostas nas prateleiras, à disposição para quem puder adquirir.

Quase todos os materiais têm sido experimentados, e o que não foi tentado acabará sendo - e o mercado de consumo se rejubila, enchendo galpões e prateleiras com os novos símbolos de identidade, originais e tentadores, já que não foram provados nem testados.[...] Selecionar os meios necessários para conseguir uma identidade alternativa à sua escolha não é mais um problema (isto é, se você tem dinheiro suficiente para adquirir a parafernália obrigatória). Está à sua espera nas lojas um traje que vai transformá-lo imediatamente no personagem que você quer ser, quer ser visto sendo e quer ser reconhecido como tal. (BAUMAN, 2005, p. 88-91).

Entretanto, há que se refletir que a Identidade Social, por mais que ela possa ser afetada pelos valores da sociedade do consumo, não é tão fácil de ser desfeita quanto trocar de roupa. Os objetos de consumo possuem signos e significados que usamos para expressar nossas 
Identidades, como descrevem bem Woodward (2000) e Silva (2000). Mas isto não significa que as Identidades são tão efêmeras e transitórias quanto os próprios bens que consumimos. Além disso, deve-se entender que há uma contradição que, por mais que pareça apenas semântica, revela uma diferença ligada à pergunta definidora da Identidade: Quem sou eu? Ser alguém pode ser definido pelos bens, mas, por exemplo, há um longo caminho que distancia entre ter uma roupa de um desportista e ser um desportista.

De forma um pouco mais ponderada, Giddens (2002, p. 183) afirma que o consumo afeta o desenvolvimento genuíno do eu de forma que "a aparência substitui a essência à medida que os signos visíveis do consumo de sucesso passam a superar a realidade dos valores de uso dos próprios bens e serviços em questão.” Ou seja, pode-se depreender desta visão que isso pode gerar mais uma angústia existencial, que na visão de Giddens (2002) conduz ao narcisismo, do que necessariamente uma nova Identidade.

Nesse sentido, levando-se em consideração que o espaço produtivo catalisa as transformações da sociedade pós-moderna, indaga-se sobre a Identidade do bancário dentro da organização e no trabalho. Com as organizações e o trabalho sendo constantemente transformados e reconfigurados pelas inovações tecnológicas e gerenciais, num ritmo insanamente constante, com o que se auto-identifica esse novo homem social dentro do espaço produtivo? No que, no trabalho e nas organizações, ele se apega para delinear sua Identidade? Como a Identidade está se cristalizando no ideário do indivíduo no que tange o espaço produtivo? Quais os reflexos da valorização do consumo e do consumidor afetam sua Identidade Social?

\subsection{TRABALHO BANCÁRIO}

Como diversos outros tipos de atividade econômica, o trabalho bancário sofreu drásticas transformações nos últimos anos, principalmente na década de 1990. O trabalho bancário de hoje difere substancialmente do realizado nas décadas de 70 e 80, tanto na forma como era organizado e executado, quanto no sentido que tinha para os que o executavam. Parte das transformações pode ser explicada pelas metamorfoses que o setor sofreu frente às novas configurações do mercado nacional e mundial, pela alteração da tecnologia e pelas mudanças políticas e econômicas acontecidas em nossa realidade.

Uma das atividades onde o trabalho tem se transformado de forma mais dramática hoje é o trabalho bancário. Esse setor tem mudado muito nos últimos anos. Qualquer pessoa que esteja habituada a fazer uso desses serviços certamente percebe muitas dessas mudanças no seu dia-a-dia, 
seja na infra-estrutura disponibilizada a clientes e funcionários - como a automação e as instalações físicas - seja em mudanças no funcionamento interno das agências, na forma de atendimento aos clientes e na natureza dos produtos oferecidos. (MERLO; BARBARINI, 2002, p. 104).

As transformações do trabalho bancário estão diretamente ligadas aos processos de mudança que aconteceram no contexto internacional e nacional. Não se pode pensar o trabalho bancário como era visto anteriormente, não só nos aspectos de execução das atividades, mas nos seus aspectos políticos, econômicos, tecnológicos e sociais. Neste sentido, é interessante ver como o contexto internacional afetou este segmento econômico.

\subsubsection{Questões contextuais e as instituições do sistema financeiro}

Chesnais (1996) relata que um dos elementos importantes no contexto das décadas de 1980 e 1990 é a integração internacional dos mercados financeiros ocasionada, principalmente, pela desregulamentação e liberação dos mercados nacionais. Chesnais (1996) não concorda com o que muitos autores têm chamado de globalização da economia, enquanto instrumento de integração e desenvolvimento dos povos. Segundo o autor, "A esfera financeira representa o posto avançado do movimento de mundialização do capital, onde as operações atingem o mais alto grau de mobilidade, onde é mais gritante a defasagem entre as prioridades dos operadores e as necessidades mundiais.” (CHESNAIS, 1996, p.239).

É possível, por meio da integração financeira, que grandes quantias de dinheiro circulem pelo mundo em um tempo significativamente menor. Para que tal fato pudesse se concretizar, foi preciso conectar os mercados financeiros das diversas nações por meio da informática, permitindo trabalhar com valores em tempo real e deslocá-los a qualquer momento.

\footnotetext{
A teleinformática (às vezes chamada "telemática") surgiu da convergência entre os novos sistemas de telecomunicações por satélite e a cabo, as tecnologias de informatização e a microeletrônica. Ela abriu, às grandes empresas e aos bancos, maiores possibilidades de controlar a expansão de seus ativos em escala internacional e de reforçar o âmbito mundial de suas operações (CHESNAIS, 1996, p. 28).
}

Esta constatação vai ser importante para que se perceba como a automação e a informatização são imprescindíveis para as instituições atreladas ao mercado financeiro. A informatização, em função dessa necessidade de agilidade e volatilidade dos capitais, tornou-se quase que um paradigma no setor financeiro - e mais especificamente no setor bancário. Primeiro, porque era preciso agilitar - e em parte desburocratizar - o processo de trabalho, em função das necessidades do capital, possibilitando realizar as operações financeiras tão rapidamente quanto necessárias. Segundo, porque era preciso maior controle sobre o andamento das 
instituições financeiras e saber a sua própria rentabilidade de forma mais ampla, detalhada e completa. Terceiro, para a construção de um instrumento de marketing para personalizar o atendimento aos consumidores por meio de gigantescos bancos de dados sobre o comportamento deles.

Chesnais (1996) destaca ainda que a rentabilidade financeira vem ganhando mais espaço do que a rentabilidade produtiva. Há hoje uma valorização extremada do desempenho financeiro da organização que, muitas vezes, entra em choque com o investimento produtivo. $\mathrm{O}$ que importa para as organizações é a rentabilidade no final de um período. Quanto mais rentável em um período de tempo menor, mais valorizada será a organização (CHESNAIS, 1996). Com isso, a visão de produtividade enquanto elemento atrelado ao trabalho é perdida.

Pouco importa o que a organização produz e como produz, desde que seja rentável em um tempo menor. Luttwak (1996) mostra que a organização, dentro desse sistema, é valorizada pelo seu desempenho financeiro, principalmente no mercado de ações, independentemente de como andam as políticas de gestão de Recursos Humanos e a situação em que se encontram os funcionários da empresa. Em alguns casos, processos de enxugamento do quadro de funcionários - que antigamente poderiam ser considerados como situações de crise e, por isso mesmo, um motivo para não se investir em determinada empresa - são aplaudidos pelos mercados financeiros sob a forma de aumento do valor de troca das ações. Na prática, isso significa que a organização estar indo bem no mercado não é, necessariamente, motivo de segurança para os trabalhadores. Enriquez (1999, p. 77) ilustra bem este processo:

A redução de pessoal acontece, mesmo quando as empresas estão funcionando bem. [...] Quanto
mais as coisas funcionam, mais se eliminam trabalhadores. [...] uma companhia sueca, Eletrolux,
de eletro-eletrônicos e outros produtos, suprimiu aproximadamente 100 mil empregos no mundo e
12 mil na matriz, porque o acionista principal queria um rendimento de $15 \%$ para as suas ações,
rendimento esse que era de $9 \%$, o que já é muito bom, porque na Suécia não há inflação.

Chesnais (1996) descreve também uma sobrevalorização do papel dos bancos nos países como vantagem estrutural para as suas economias. Segundo esse autor, os bancos vão dar suporte ao desenvolvimento fabril, servindo como incentivo às empresas multinacionais para instalarem unidades produtivas em determinadas regiões. Pode-se dizer que, além do incentivo em termos de fonte de recursos, os bancos têm um importante papel que é o de fazer as intermediações financeiras entre países. Isso se traduz na internacionalização do setor bancário com forte apoio empresarial e governamental. Nesse processo, diversos bancos abrem filiais internacionais para ganhar em cima das transações produtivas entre os países ou 
entre as empresas. Dentro dos setores bancários, principalmente dos países em desenvolvimento, isso significa um forte aumento da competitividade.

Percebe-se que o setor financeiro vem sofrendo modificações como um todo, tendo, como conseqüências mais evidentes a internacionalização, o aumento da competitividade e reestruturação tecnológica.

\subsubsection{Características do trabalho bancário}

Antes de compreender o impacto das transformações sobre o trabalho bancário no Brasil, é preciso entender que essa atividade profissional possui algumas características que a distinguem de muitas outras, principalmente quando comparada aos demais prestadores de serviços.

Uma dessas características é a burocratização dos processos que está intrinsecamente associada à natureza do serviço vendido. Tudo precisa ser documentado, guardado e contabilizado de forma a possibilitar o controle do desempenho e o controle fiscal em função de eventuais auditorias. Isso implica forte prescrição de algumas tarefas, traduzidas em normas, procedimentos e regras a serem seguidas. Grande parte das normas é feita para a própria segurança do banco, dos consumidores e dos funcionários, tais como conferência de assinatura, conferência de dados na entrega de talão de cheque, registro da realização de transações financeiras dentre outros.

A natureza do objeto de trabalho também é sui generis. Isso por ser composto apenas por números, por valores financeiros, quantias vultosas e pequenas ao mesmo tempo, que, no final do dia, continuam a ser apenas dígitos que não expressam nenhuma conquista ou realização. Codo e Sampaio (1992) classificam o trabalho bancário como sendo "vazio", pois não constrói um produto final tangível. Segundo esses autores, muitos funcionários relataram seu sofrimento como sendo decorrente de uma falta de satisfação com o trabalho executado. Recorremos à descrição do trabalho bancário de Falqueto (1997), que corrobora as afirmações feitas por Codo e Sampaio (1992):

O que faz o bancário? Paga, recebe, vende produtos, realiza empréstimos, cobra operações vencidas. É um trabalho repetitivo, monótono e metódico. Por exemplo: o caixa inicia o expediente com zero e encerra com zero; [...] O bancário (a) trabalha com excesso de papel, regras e normas, em geral muito rígidas. Qual o produto de seu trabalho? Ele(a) manipula dinheiro que gera dinheiro, não construindo nenhum produto final. É um trabalho vazio. (FALQUETO, 1997, p. 67). 
Moulin (1996) chama atenção para o fato de que o bancário, muitas vezes, sente-se realizado em seu trabalho por meio do bom atendimento ao consumidor. Entretanto, no relacionamento entre bancário e consumidor, a literatura sobre os bancos enfatiza problemas e conflitos (Moulin, 1996 e 1997; Silva, 1992; AsSUnÇãO, 1993). Além disso, os consumidores seriam a forma como os bancários têm seu trabalho reconhecido e, também, são responsáveis por uma fonte de pressão sobre a forma como executam o trabalho (VELOSO, 2000).

Uma vez compreendidas essas especificidades do trabalho bancário, passa-se a descrever as alterações que o setor sofreu nos últimos anos no Brasil, como forma de descrever o contexto em que tais profissionais atuam.

\subsubsection{Alterações no setor bancário no Brasil}

Nesta parte, será dada maior atenção às transformações das últimas três décadas no setor no Brasil. O foco principal de análise dessas alterações concentra-se nas décadas dos anos 1980 e 1990, por ser nesse período em que se engendram os processos considerados como os grandes responsáveis pela configuração que assume o trabalho bancário no contexto brasileiro atual.

A competitividade do setor bancário no Brasil, no início da década de 1980, pode ser considerada baixa, principalmente em relação aos tempos atuais. O setor encontrava-se oligopolizado, em função de uma política econômica adotada pelo Estado, que privilegiava a concentração bancária e a formação de conglomerados financeiros. O objetivo dessa política era construir um forte suporte ao capital industrial, ao setor comercial e ao setor de serviços (FREITAS, 1995).

A partir de 1986, mudanças nas políticas econômicas do governo fazem com que o setor bancário passe por momento de transição. O Plano Cruzado, no governo Sarney, estabelece o congelamento de preços que resulta numa queda vertiginosa e instantânea da inflação, para a qual os bancos não estavam preparados. A rentabilidade dos bancos é imediatamente afetada e os impactos dessa nova realidade concretizam-se nas políticas dessas organizações. Inicia-se um processo de "ajustes administrativos" que culminam em processos de demissão, programas de inovação tecnológica, reorganização dos processos de trabalho e reestruturação produtiva. Entretanto, a volta da inflação não desestimulou, como se percebe pelo texto de Segnini (1998), a continuidade dos ajustes administrativos.

Em 1988, o Banco Central extingue a "carta patente", que limitava a inserção de novos 
bancos no mercado. Há, portanto, uma quebra da oligopolização, aumentando a sua competitividade interna. Esse fato pode ser visto como um propulsor à reestruturação iniciada naquela época.

Na década de 90, a abertura de mercado no governo Collor proporcionou a inserção de bancos internacionais no mercado interno. Os bancos nacionais estavam diante de concorrentes que traziam uma bagagem em termos de avanço tecnológico, gerencial e técnico, forçando ainda mais a necessidade de reestruturação das empresas brasileiras. Os bancos estrangeiros instalaram-se no Brasil buscando objetivos diversos. Alguns estavam interessados no estreitamento comercial entre os países, enquanto outros buscavam um mercado de varejo potencialmente grande.

Percebe-se que as organizações do setor respondiam bem às alterações do mercado. Por meio da forte contenção de custos, tais como redução da estrutura de recursos humanos e terceirização de processos, e de bem sucedidas operações de crédito, principalmente advindos de empréstimos para financiar a reestruturação dos demais setores do mercado, em 1992, o setor bancário é considerado o mais lucrativo da economia. Percebe-se que parte desse processo teve impactos diretos sobre a categoria profissional dos bancários, como será visto adiante.

A estabilização da economia em 1994, proporcionada pelo Plano Real, teve conseqüências semelhantes aos acontecimentos de 1986. Entretanto, os ajustes administrativos foram intensificados e foram incorporadas políticas de marketing mais agressivas, aliadas à utilização da informática, visando a captação de consumidores.

Em 1994, depois da abertura da economia por Collor e no início do Plano Real, o número de bancos volta a crescer. Já em 1996, há uma queda do número de instituições, provocada principalmente por fusões, aquisições e falências, gerando um processo de concentração financeira no setor. Segundo dados do Banco Central do Brasil, entre Julho de 1995 e outubro de 2006, aconteceram 84 fusões, aquisições ou incorporações no setor bancário (Vide Quadro $1)$. 
Quadro 1 - Número de fusões, aquisições e incorporações por ano no setor bancário do Brasil entre Julho de 1995 e Outubro de 2006

\begin{tabular}{|l|c|c|c|c|c|c|c|c|c|c|c|c||}
\hline Ano & $\mathbf{1 9 9 5}^{1}$ & $\mathbf{1 9 9 6}$ & $\mathbf{1 9 9 7}$ & $\mathbf{1 9 9 8}$ & $\mathbf{1 9 9 9}$ & $\mathbf{2 0 0 0}$ & $\mathbf{2 0 0 1}$ & $\mathbf{2 0 0 2}$ & $\mathbf{2 0 0 3}$ & $\mathbf{2 0 0 4}$ & $\mathbf{2 0 0 5}$ & $\mathbf{2 0 0 6}^{2}$ \\
\hline $\begin{array}{l}\text { Quantidade } \\
\text { de fusões e } \\
\text { aquisições }\end{array}$ & 5 & 14 & 18 & 12 & 4 & 6 & 4 & 6 & 8 & 2 & 0 & 5 \\
\hline Total & \multicolumn{80}{|c|}{$\mathbf{8 4}$} \\
\hline
\end{tabular}

Fonte: FEBRABAN (2008)

Nota: 1 - dados de 1995 a partir de julho. 2 - dados de 2006 até outubro

Segundo o DIEESE (2007), os processos de fusão, aquisição e incorporação têm gerado desemprego no setor, na medida em que as unidades incorporadas, em muitos casos, possuem agências ou Postos Avançados Bancários (PABs) dentro do mesmo espaço geográfico das instituições que as estão adquirindo, fundindo ou incorporando. Entretanto, embora a concentração do setor esteja se evidenciando, a competitividade do setor ainda é acirrada.

Em que pese a maior concentração bancária, a necessidade de ampliar as operações de crédito continuará impulsionando a concorrência no setor. Nesse aspecto, infere-se que a atual concorrência decorre mais do atual ambiente macroeconômico do que da iniciativa dos bancos em distribuir os ganhos de produtividade acumulados nos últimos anos. (DIEESE, 2007).

Como parte dos ajustes administrativos, destaca-se a redução do número de postos de trabalho. O Quadro 2 mostra dados do período de reestruturação produtiva no setor, entre os anos de 1989 e 1996.

Quadro 2 - Número estimado de empregados nos bancos no Brasil entre 1989 e 1996.

\begin{tabular}{|c|c|c|c|c|c|c|c|c|}
\hline & 1989 & 1990 & 1991 & 1992 & 1993 & 1994 & 1995 & 1996 \\
\hline Jonim & 811.892 & 825.558 & 748.949 & 696.874 & 681.614 & 670.117 & 632.761 & 568.786 \\
\hline $\mathrm{Fe}$ & 3.076 & 825.081 & 745.564 & 94.839 & 680.638 & 668.917 & 629.251 & 564.152 \\
\hline Marc & 1.542 & 826.244 & 739.578 & 694.800 & 678.962 & 666.743 & 623.749 & 559.765 \\
\hline $\mathrm{A}$ & & +3 & 734 & 34 & & 664 & 60 & 555 \\
\hline Maio & 30 & 810.419 & 732.026 & 692.588 & 676.779 & 661.906 & 616.847 & 547.715 \\
\hline Junho & 01 & 794.897 & 731.925 & 691.266 & 676.052 & 659 & 751 & 532.003 \\
\hline Julho & 8 & 778. & 723.279 & 89.244 & 76.549 & 657 & 59 & 528 \\
\hline 1 & & 771 & 717 & 687.827 & 677.884 & 653.272 & 588.927 & 520.093 \\
\hline Setel & 815 & 768.287 & 714.089 & 687.843 & 677.574 & 651.022 & 50 & 39 \\
\hline $\mathrm{Or}$ & 80 & 763.105 & 708 & 686.376 & 676.369 & 646 & 581.758 & 518.714 \\
\hline Nove & 822 & 758.466 & 703.729 & 71 & +38 & 641.302 & 577.436 & 513.861 \\
\hline 10 & 824.316 & 753.636 & 700.217 & 682.304 & 671.740 & 637.647 & 571.582 & 497.108 \\
\hline
\end{tabular}

Fonte: DIEESE (1997b)

Percebe-se que no ano de 1989, entre janeiro e dezembro, o setor encontrava-se em expansão 
em termos do número de empregados. A partir de 1990, inicia-se um processo de enxugamento, sendo que dos 824.316 postos de trabalho existentes em dezembro de 1989 , apenas 497.108 eram registrados pelo CAGED do Ministério do Trabalho, ou seja, uma redução de $38,77 \%$.

O processo de reestruturação implementado no sistema financeiro, na década de 90, provocou uma perda expressiva de ocupações no setor bancário. As fusões e aquisições que proliferaram nesta década, em conjunto com as inovações tecnológicas no setor, provocaram enxugamento dos empregos, como forma de reduzir os gastos totais, e, em particular as despesas de pessoal. (DIEESE, 2007).

Aparentemente, o número de postos de trabalho estabilizou-se no final da década de 1990, não havendo drásticas reduções após aquela época. Analisando-se dados de 2005 e 2006, não se observa uma tendência de redução ou expansão do número de postos de trabalho no setor. Entretanto, há demissões e admissões acontecendo em igual proporção, sugerindo, segundo (DIEESE, 2006), uma rotatividade no setor.

\footnotetext{
Cabe acrescentar que a rotatividade não é influenciada exclusivamente pela busca por redução nos gastos com mão-de-obra. Estão associados ao fenômeno fatores como tempo de casa do empregado e curva de experiência, reorganização do trabalho e adequação do perfil do trabalhador às estratégias de negócio da empresa. (DIEESE, 2006, p.3).
}

Ainda sobre esses ajustes, e, vinculado a esse movimento de enxugamento, relata-se um forte processo de automatização nos bancos, motivado tanto pela difusão das práticas de redução de custos quanto pela busca de agilização e centralização das informações (ACCORSI, 1992), sendo essa última considerada como de importância estratégica para essas organizações.

Em termos de transformação tecnológica, é no início da década de 80 que começam a ser implantados sistemas on-line, interligando as diversas agências (ACCORSI, 1992). Esses sistemas incorporam parte do trabalho que antes era feito pelo bancário e, de certo modo, aumentam o controle sobre o trabalhador. A tecnologia é implementada principalmente para reduzir os custos operacionais, aumentar a competitividade e servir como instrumento de marketing.

\footnotetext{
A manipulação de produtos envolvendo inteligência artificial simplificou-se e desmitificou-se. Os produtos tecnológicos estão disponíveis de modo mais acessível, a relação custo/benefício justifica os investimentos e a utilização destas tecnologias: "A importância da tecnologia para a promoção de negócios no universo dos bancos brasileiros e a interação entre os recursos de informática e marketing é de cerca de 70\%". (FREITAS, 1995, p.2).
}

Ressalta-se também a importância estratégica mercadológica da automação bancária descrita por Segnini (1998, p.21) que diz que “os registros rápidos e seguros passaram a ser 
fundamentais em termos de lucratividade." Isso porque os bancos passam a competir agressivamente pelos consumidores no mercado. Segnini (1998) chega a considerar o sistema financeiro do Brasil como um dos mais informatizados do mundo.

Ainda hoje, há um forte investimento das instituições bancárias na ampliação da base de máquinas que executam as atividades operacionais. Segundo dados da FEBRABAN (2008), em 2000, haviam 15.639 máquinas de auto atendimento para saque e depósito, sendo que em 2006 eram 53.427 unidades, correspondendo a um crescimento de 342\% num período de sete anos (Vide Quadro 3).

Quadro 3 - Máquinas de auto-atendimento para saque e depósito no setor bancário do Brasil de 2000 a 2006

\begin{tabular}{|c|c|c|c|c|c|}
\hline Ano & $\begin{array}{c}\text { Máquinas em } \\
\text { agências }\end{array}$ & $\begin{array}{c}\text { Máquinas em ante } \\
\text { salas de auto- } \\
\text { atendimento }\end{array}$ & $\begin{array}{c}\text { Quiosque em } \\
\text { local público }\end{array}$ & $\begin{array}{c}\text { Postos de } \\
\text { Atendimento }\end{array}$ & Total \\
\hline 2000 & 4.602 & 7.476 & 2.975 & 586 & 15.639 \\
\hline 2001 & 4.717 & 11.677 & 3.340 & 2.803 & 22.537 \\
\hline 2002 & 11.490 & 14.157 & 4.396 & 3.190 & 33.233 \\
\hline 2003 & 16.145 & 16.636 & 5.201 & 3.577 & 41.559 \\
\hline 2004 & 15.268 & 24.530 & 4.214 & 4.208 & 48.220 \\
\hline 2005 & 14.535 & 28.446 & 4.322 & 4.749 & 52.052 \\
\hline 2006 & 14.224 & 29.783 & 4.036 & 5.384 & 53.427 \\
\hline
\end{tabular}

Fonte: FEBRABAN (2008)

Em termos de atendimentos, o ano de 2006 registrou 36,7 bilhões de transações bancárias (Vide Tabela 1), segundo a FEBRABAN (2008). O auto-atendimento foi responsável por 32,4\% das transações do ano. É importante observar o crescimento das formas alternativas para as transações bancárias, destacando-se os Débitos automáticos (24,5\%) e o Internet Banking $(16,8 \%)$. Apenas em quarto lugar encontram-se os atendimentos realizados diretamente pelos caixas de agências $(10,4 \%)$. Isto mostra que há uma forte capacidade de absorção do trabalho bancário por formas alternativas de execução dos atendimentos. Os bancos podem ampliar o volume de trabalho, no que diz respeito às atividades de rotina bancária, sem que isso implique em uma expansão considerável dos seus quadros de funcionários. Deve-se lembrar que estão excluídas dessas atividades a prestação de informações e esclarecimentos, as vendas e o cumprimento de metas bem como outras atividades que fazem parte do contexto atual dos trabalhadores deste setor. 
Tabela 1 - Número de transações realizadas no setor bancário no Brasil em 2006

\begin{tabular}{lcc}
\hline \hline Forma de execução dos atendimentos & $\begin{array}{c}\text { Número (em milhões de } \\
\text { transações) }\end{array}$ & \% sobre o Total \\
\hline Caixas de agências & 3.799 & $10,4 \%$ \\
Auto Atendimento & 11.901 & $32,4 \%$ \\
Call Center & 1.194 & $3,3 \%$ \\
Internet Banking & 6.163 & $16,8 \%$ \\
Débitos automáticos & 8.995 & $24,5 \%$ \\
Número de cheques compensados & 1.709 & $4,7 \%$ \\
Correspondentes e Pontos de vendas & 2.921 & $8,0 \%$ \\
\hline Total & 36.682 & $100,0 \%$ \\
\hline
\end{tabular}

Fonte: FEBRABAN (2008)

Entretanto, não se pode atribuir exclusivamente às inovações tecnológicas a causa das demissões em massa. Segundo Ely (1993), os bancos passaram também por processos de inovação das técnicas de gestão e por terceirizações que reforçaram o movimento de enxugamento.

Percebe-se também uma horizontalização no setor bancário, com a redução dos níveis de gerência intermediária, e um aumento da importância dos funcionários que possuem um maior contato com os consumidores, como os gerentes e caixas. Ou seja, a importância dos funcionários está vinculada ao atendimento do consumidor. Tem-se constatado também que as tarefas dos gerentes têm-se tornado mais complexas, enquanto nos níveis hierárquicos mais baixos - como os caixas - têm ficado mais simples e mais fragmentadas (VALLE, 1995).

Ely (1993) relata que em alguns casos ampliou-se o número de estagiários como forma de redução de custos e de precarização das condições de trabalho. Isso porque os estagiários trabalham em câmaras de compensação ou de processamento de dados, realizando tarefas extremamente fragmentadas - como a digitação de cheques compensados - e não têm a maioria dos direitos comuns aos funcionários com carteira assinada. É preciso compreender que a inserção de estagiários nos bancos causa um forte impacto tanto na dinâmica interna do banco como no mercado de trabalho. Isso porque evidencia uma desvalorização do trabalho bancário, na medida em que pessoas menos qualificadas podem realizá-lo e recebendo menos por isso.

Uma modificação importante neste contexto é que os bancários agora precisam lidar com uma série de produtos financeiros e, além disso, precisam saber vendê-los aos consumidores. Isso tem sido relatado como um ponto que interfere na relação do indivíduo com o seu trabalho. 
modos de trabalhar já que demandaram dos bancários uma atuação intensiva em vendas e, portanto, criaram novos modos de subjetivação aos quais os trabalhadores bancários ficaram expostos. Para os bancários mais antigos, tais modos de subjetivação não se mostraram indolores, pois eles foram construídos num trabalho bancário de outra natureza, mais burocratizado e sem a necessidade da atuação como vendedores. (GRISCI; BESSI, 2004, p. 191).

É de responsabilidade do funcionário a venda desses produtos aos consumidores. Alguns produtos, em função de suas características próprias, requerem um conhecimento diferenciado de finanças e de mercado financeiro, de forma que o funcionário possa aconselhar o consumidor sobre suas opções. Isso também pode ser visto como uma forma de qualificação para o bancário à medida que exige uma visão de analista.

Observa-se que, com as estruturas mais enxutas, os bancos precisam reestruturar o processo produtivo. Com uma quantidade menor de pessoas, o trabalho é então redistribuído para os demais, significando que, além das novas funções, o bancário assume quantitativamente o trabalho dos que saíram. Embora grande parte desse trabalho tenha sido assimilado pelas máquinas, novas tarefas surgem com a automação, tais como a conferências dos dados, a alimentação das máquinas, a manutenção dos sistemas de informação dentre outros.

Outro ponto para compreender a transformação do trabalho neste setor é que o bancário era possuidor de uma profissão reconhecida socialmente e que, com os processos de reestruturação, tal status se perdeu.

(..) trabalho bancário tinha uma conotação diferenciada da atual. A natureza do trabalho, o seu produto e o status da função de bancário proporcionavam a esse trabalhador a percepção de que o seu trabalho tinha uma importância elevada para a sociedade. (GRISCI; BESSI, 2004, p. 172).

As transformações acontecidas e relatadas no setor são responsáveis por grande parte das mudanças do trabalho bancário. A reestruturação do sistema financeiro e o aumento da competitividade implicaram fortes ajustes na organização do processo de trabalho e na estrutura dos bancos. Couto (2000) afirma que:

\footnotetext{
Assim sendo, a realidade do setor bancário no Brasil, nas décadas de 80 e 90, foi de aumento das exigências para os trabalhadores, sendo as principais: o trabalho sob pressão (tanto por clientes quanto por parte das chefias), os sistemas de trabalho ineficientes, os postos de trabalho inadequados, os riscos de assaltos e os sistemas informatizados impondo novos ritmos para o ser humano. (COUTO, Op. cit., p.322).
}

Couto (Op. cit) chama a atenção para alguns fatos importantes que podem ser considerados como características intrínsecas ao trabalho bancário nos dias atuais. Um dos pontos é que o consumidor tem sido um dos que vêm exercendo pressão sobre o bancário. Isso porque o funcionário é a imagem viva da organização, representando seus valores, sua postura e seus 
objetivos. Durante a prestação do serviço, o funcionário é o responsável por reconstruir a imagem institucional e repassá-la para o consumidor, de forma que esse último reconheça, no bancário e no serviço oferecido, os valores repassados tanto pelas campanhas de propaganda e marketing quanto pelo discurso de valorização do consumidor. A contradição entre os valores repassados e o mau serviço prestado, seja por culpa do funcionário ou não, gera a insatisfação do consumidor. Por ser o ponto de contato com o consumidor, o bancário é o canalizador das reclamações quanto ao serviço prestado. Tais constatações também se fizeram presentes no trabalho de Veloso (2000).

Analisando as transformações do setor, Gomes (1994) concluiu que após as inovações tecnológicas o bancário reduziu a sua visão do trabalho como um todo, uma vez que tais profissionais tiveram seu trabalho simplificado.

O processo de reestruturação produtiva, aliado ao contexto econômico e às políticas governamentais fizeram do setor bancário um dos mais rentáveis da economia. Quando se analisa a rentabilidade das 11 maiores instituições do setor (Vide Gráfico 1), percebe-se que, no momento da reestruturação produtiva, em 1995 e 1996, os bancos apresentavam prejuízo. Tais prejuízos são explicados pelo fim da inflação, e conseqüente fim do ganho de tais instituições com a desvalorização da moeda, pelo forte investimento em automação, pelos pagamentos das indenizações pelos processos de redução dos quadros de funcionários e, em alguns casos, pelos resultados dos processos de fusão e aquisição. Há um ponto de inflexão, de forma que o lucro líquido, a partir de 1997, começa a se restabelecer.

A partir de 2001 a rentabilidade do setor cresce vertiginosamente, impulsionada pelos juros altos do mercado, pelo aumento das tarifas dos serviços prestados, pelo processo de inclusão bancária, que aumenta a base de clientes, e pela diversificação do portifólio de produtos financeiros disponíveis no mercado, tais como empréstimo consignado, microcrédito, novas linhas de financiamento dentre outros.

\footnotetext{
Após o impacto inicial do Plano Real, com o fim da receita inflacionária, os bancos passaram a acumular sucessivos recordes de lucratividade com aumentos expressivos de receitas e redução de custos. Entre 1994 e 2006, a receita de prestação de serviço global dos onze maiores bancos registrou um aumento real (acima da inflação) de $222 \%$ em relação ao Índice Geral de Preços Disponibilidade Interna (IGP-DI), calculado pela Fundação Getúlio Vargas (FGV). No mesmo período, a despesa de pessoal total desses bancos caiu $34,6 \%$, o que resultou num aumento real de $611,3 \%$ do lucro líquido global. (DIEESE, 2007, p.7).
} 
(em R $\$$ bi)

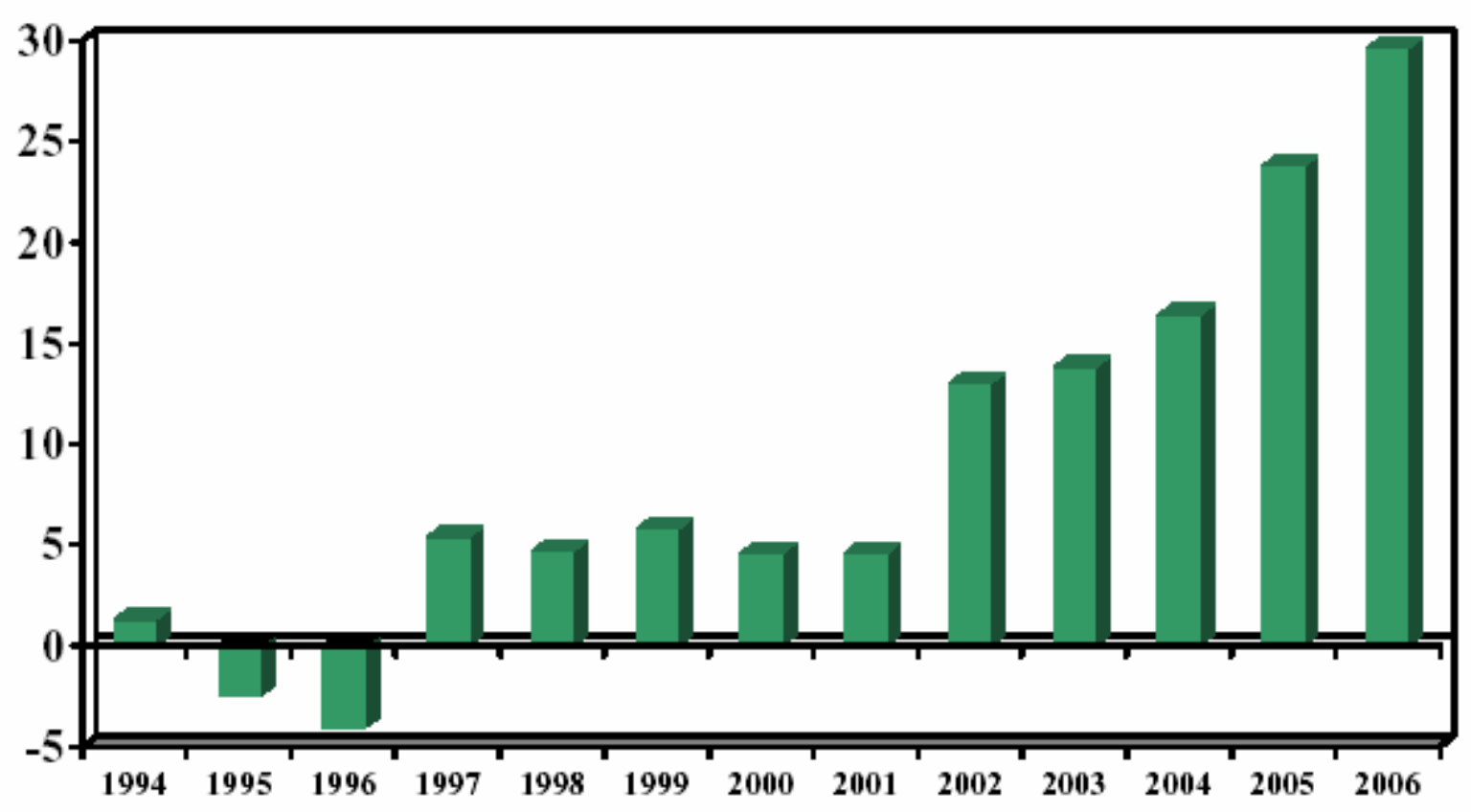

Gráfico 1 - Lucro líquido dos 11 maiores bancos no Brasil entre os anos 1994 e 2006. Fonte: DIEESE (2007)

Embora, a partir de setembro de 2005, o Banco Central tenha reduzido a taxa Selic de forma constante, passando de 19,75\% em agosto de 2005 para 13,25\% em dezembro de 2006, a rentabilidade dos bancos não apresentou queda, porque as instituições mantiveram quase inalterados os seus spreads bancários (DIEESE, 2006b). Além disso, estudos mostram que os bancos têm aumentado o faturamento respectivo às tarifas dos serviços prestados tais como manutenção de contas, emissão de extratos, movimentações financeiras dentre outros (DIEESE, 2006c).

A forte competitividade do setor direcionou as instituições bancárias para estratégias de segmentação de mercado, focando públicos alvos distintos. Segundo o DIEESE (2007), os dois principais segmentos nos quais os bancos estão direcionando seus esforços competitivos no atual contexto é um popular e o outro sofisticado.

Nesse contexto, a segmentação da atividade bancária é uma estratégia que visa explorar oportunidades em dois segmentos: um popular e outro sofisticado. Os dois públicos apresentam perspectivas de mercado, rentabilidade e expansão diferentes. O primeiro oferece produtos e serviços mais homogêneos voltados para mercados de massa. O segundo oferece produtos e serviços cada vez mais diferenciados para pessoas físicas de renda elevada e para clientes corporativos com alta rentabilidade para o banco. A disputa por esse segmento é mais acirrada e, por isso, exige capacidade de inovação, atendimento individualizado e assessoria especializada. Nele, a utilização de preços como instrumento competitivo perdeu parte da importância de 
outrora.(DIEESE, 2007, p.9).

Subentende-se, neste sentido, que a classe bancária convive com realidades distintas dependendo da forma como sua organização se posicionou em termos de estratégia corporativa. Dentro do segmento popular, o volume de clientes e demanda destes por serviços bancários deve ser quantitativamente superior, enquanto que no segmento sofisticado a diversificação de produtos e a exigência dos clientes por atendimento personalizado é que deve predominar na execução do trabalho.

As transformações contextuais das últimas três décadas, como pode ser depreendido dos textos dos autores trabalhados, afetaram a categoria profissional, o trabalho e as organizações, elementos esses que são entendidos como as referências identitárias para os indivíduos no mundo do trabalho. É nesta contextualização que esta pesquisa busca entender como as Identidades Sociais dos indivíduos, especificamente dos bancários, estão sendo afetadas e se reposicionando. 
CAPÍTULO 3 - ASPECTOS METODOLÓGICOS DA PESQUISA

Dizem que é possível saber mais de uma pessoa conhecendo o caminho que percorreu do que aonde chegou. Entretanto, muitas vezes, o caminho é mais valorizado do que o elemento essencial em toda discussão: o que se quer conhecer, antes de tudo, é a pessoa. 


\subsection{MÉTODO DE PESQUISA}

Para se delinearem os procedimentos metodológicos que nortearam o esforço desta pesquisa, partimos das características do constructo Identidade bem como da opção por um enfoque construcionista para lidar com o tema.

O constructo Identidade não é novo, mas, por estar diretamente associado a questões que envolvem o fórum íntimo do indivíduo, dificilmente pode ser compreendido por meio de uma concepção puramente quantitativa. Requer, por sua natureza, uma análise qualitativa em profundidade, o que implica delimitações prévias ao processo de escolha das opções de pesquisa. Ou seja, o constructo é por demais complexo para ser analisado de forma extensiva/quantitativa, requerendo, portanto, uma compreensão intensiva/qualitativa.

Outro ponto importante, diz respeito à inserção do tema dentro dos estudos organizacionais. Dentro do contexto das pesquisas de âmbito nacional, a Identidade Social ainda carece de estudos sistematizados para compreendê-la no ambiente organizacional, principalmente como elemento associado a problemas que envolvam o consumo e a produção.

Neste sentido, há uma tendência de o direcionamento para uma abordagem mais qualitativa em termos metodológicos. A opção por um enfoque construcionista de Identidade também conduz para uma abordagem de caráter qualitativo, na medida em que o discurso construído pelo indivíduo é essencial para a compreensão do sujeito.

Para Flick (2004, p. 20), a complexidade da realidade atual, em muitos casos, dificulta a opção por processos de investigação dentro dos moldes quantitativos, aumentando a valorização dos estudos qualitativos:

O fato de que a maioria dos fenômenos da realidade, de fato, não possam ser explicados de forma isolada é resultado da complexidade da realidade e dos fenômenos. Se todos os estudos empíricos fossem planejados exclusivamente de acordo como o modelo das nítidas relações de causa e efeito, todos os objetos complexos teriam de ser excluídos.

O mesmo autor (FLICK, op.cit) orienta para a necessidade de se buscar métodos abertos que sejam condizentes com a complexidade do objeto em estudo. Complexidade esta que entendemos ser característica do constructo Identidade. Tendo como referência o trabalho de Toulmin (1990), Flick (op.cit) salienta que no auge da modernidade, no contexto das diversidades contextuais e com os objetos de estudo social tornando-se mais complexos, quatro tendências podem ser observadas em termos de pesquisa empírica: o retorno ao oral, 
entendendo por isso a realização crescente de estudos que se centrem nas narrativas, na linguagem e na comunicação; o retorno ao particular, como uma forma de sair do geral e abstrato que foge dos problemas concretos, sendo que estes últimos são entendidos como distantes da normalidade; o retorno ao local em que o estudo se torna contextualizado nas tradições e formas de vida locais, ao invés de buscar respostas de validade universais e; o retorno ao oportuno, em que os problemas e as soluções são desenvolvidas dentro de contexto temporal ou histórico específico, ou seja, de validade determinada.

\begin{abstract}
A mudança social acelerada e a conseqüente diversificação das esferas de vida fazem com que os pesquisadores sociais defrontem-se, cada vez mais, com novos contextos e perspectivas sociais; situações tão novas para eles que suas metodologias dedutivas tradicionais - questões e hipóteses de pesquisa derivadas de modelos teóricos e testadas sobre a evidência empírica - fracassam na diferenciação de objetos. (FLICK, 2004, p. 18).
\end{abstract}

Embora tais tendências possam estar sujeitas a questionamentos no que tange a totalidade de sua aplicação no campo das pesquisas sociais, mostram uma preocupação direcionada às questões e problemas da realidade complexa a que estão submersos os objetos de estudo. Neste sentido, Flick (2004, p. 28) reforça:

A pesquisa qualitativa é orientada para a análise de casos concretos em sua particularidade temporal e local, partindo das expressões e atividades das pessoas em seus contextos locais. Portanto, a pesquisa qualitativa está em condições de traçar caminhos para a psicologia e as ciências sociais concretizarem as tendências mencionadas por Toulmin, de transformá-las em programas de pesquisa e de manter a flexibilidade necessária em relação a seus objetos e tarefas.

Stevanato (2004), no seu estudo sobre Identidades Sociais, reforça que, dada a complexidade do fenômeno e a necessidade de se dar conta dos fenômenos subjetivos atrelados ao constructo, a pesquisa qualitativa torna-se um instrumento adequado para as questões dessa natureza.

Enquadrando-se como pesquisa qualitativa, para entender a complexidade da Identidade Social inserida no contexto local e temporal a que pertence, este estudo pode ser descrito segundo os critérios utilizados por Cooper e Schindler (2003), como no quadro que se segue: 
Quadro 4 - Descritores do planejamento desta pesquisa segundo quadro elaborado por Cooper e Schindler (2003)

\begin{tabular}{|c|c|c|}
\hline Categoria & $\begin{array}{l}\text { Opções a serem escolhidas } \\
\text { segundo os autores }\end{array}$ & $\begin{array}{l}\text { Opção feita para esta } \\
\text { pesquisa especificamente }\end{array}$ \\
\hline $\begin{array}{l}\text { O grau em que as questões de pesquisas } \\
\text { foram cristalizadas }\end{array}$ & $\begin{array}{l}\text { Estudo Exploratório } \\
\text { Estudo Formal }\end{array}$ & Estudo Exploratório \\
\hline O método de coleta de dados & $\begin{array}{l}\text { Monitoramento } \\
\text { Interrogação/comunicação }\end{array}$ & Interrogação/comunicação \\
\hline $\begin{array}{l}\text { O poder do pesquisador de produzir efeitos } \\
\text { nas variáveis que estão sendo estudadas }\end{array}$ & $\begin{array}{l}\text { Experimental } \\
\text { Ex post facto }\end{array}$ & Ex post facto \\
\hline O objetivo do estudo & $\begin{array}{l}\text { Descritivo } \\
\text { Causal }\end{array}$ & Descritivo \\
\hline A dimensão do tempo & \begin{tabular}{|l|} 
Transversal \\
Longitudinal \\
\end{tabular} & Transversal \\
\hline O ambiente de pesquisa & $\begin{array}{l}\text { Ambiente de campo } \\
\text { Pesquisa em laboratório } \\
\text { Simulação }\end{array}$ & Ambiente de campo \\
\hline $\begin{array}{|llll|}\text { As percepções das pessoas sobre a } \\
\text { atividade de pesquisa }\end{array}$ & \begin{tabular}{|l|} 
Rotina real \\
Rotina modificada \\
\end{tabular} & Rotina modificada \\
\hline
\end{tabular}

Fonte: Cooper e Schindler (2003)

Nota: quadro adaptado pelo autor

As características do objeto de pesquisa e sua inter-relação dentro do quadro referencial teórico dos estudos em Administração, direcionam esta pesquisa para se configurar como Estudo Exploratório. Segundo Cooper e Schindler (2003, p. 128), os "estudos exploratórios tendem a gerar estruturas soltas com o objetivo de descobrir futuras tarefas de pesquisa". Neste sentido, ao final desta pesquisa, procurou-se tecer contribuições teóricas sobre o tema de forma a subsidiar outros Estudos Formais. Gil (1999, p. 43) afirma que as pesquisas exploratórias:

[...] são desenvolvidas com o objetivo de proporcionar visão geral, de tipo aproximativo, acerca de determinado fato. Este tipo de pesquisa é realizado especialmente quando o tema escolhido é pouco explorado e torna-se difícil sobre ele formular hipóteses precisas e operacionalizáveis.

Embora o tema Identidade Social não seja inédito em termos de estudo no Brasil, dentro do contexto das relações de consumo e produção ainda são desconhecidos estudos sistemáticos que permitam a estruturação do problema com a mesma clareza de um estudo formal - como na conceituação de Cooper e Schindler (2003).

O método de coleta de dados configura-se como Interrogação/Comunicação por coletar dados por meio do questionamento e busca de respostas por meios pessoais ou impessoais (COOPER; SCHINDLER, 2003). O constructo Identidade é normalmente captado em termos de pesquisa por meio do discurso do entrevistado e da reconstrução e interpretação devidamente contextualizada de seu discurso (SPINK; FrEZZA, 1999). 
O discurso tem, no enfoque construcionista, papel central para a reconstrução do sujeitoobjeto - aqui entendido como inseparáveis - na medida em que são frutos de uma construção social. O indivíduo, que se reconstrói a cada relação social com o outro ou com seu contexto de forma autopoiética, expressa, por meio do seu discurso, quem ele é (MATURANA; VARELA, 1995; SPINK; FREZZA, 1999).

Flick (2004) descreve o discurso e a narrativa como elementos centrais na construção do "texto". "No processo de reconstrução de casos, são produzidos textos nos quais se fazem as análises empíricas reais: a opinião do sujeito é reconstruída como sua teoria subjetiva, ou assim formulada" (FLICK, 2004, p. 42).O "texto", dentro da concepção de Flick (2004), representa os dados, a base da interpretação do material empírico e o meio central para a apresentação e comunicação das descobertas. Dessa forma, como fruto da Interrogação/comunicação, o material empírico dessa pesquisa será o "texto" construído a partir da fala dos bancários.

Ciampa (2005) vale-se da construção de "textos", a partir da narrativa e do discurso, para compreender o constructo Identidade, mostrando a necessidade de um estudo aprofundado para compreender como se dá a dinâmica dessa variável. De forma análoga, Silva (2000) mostra que as Identidades ganham significado a partir das representações feitas pelos indivíduos e que são atos de criação lingüística. Por isso, o resgate da reconstrução feita pelo sujeito é condição sine qua non para compreensão do constructo. Hall (2000, p. 109) reforça esta concepção ao afirmar que "[...] é na tentativa de rearticular a relação entre sujeitos e práticas discursivas [...]" que seus problemas devem ser compreendidos.

É precisamente porque as identidades são construídas dentro e não fora do discurso que nós precisamos compreendê-las como produzidas em locais históricos e institucionais específicos, no interior das formações e práticas discursivas específicas, por estratégias e iniciativas específicas. (HALL, 2000, p. 109).

Não houve qualquer tipo de controle ou manipulação de variáveis ou o acompanhamento dessas manipulações durante a pesquisa. Por isso mesmo, trata-se de uma pesquisa Ex post facto (COOPER; SCHINDLER, 2003). Retomando os conceitos de Kerlinger (1979), Gil (1999, p. 69) define a pesquisa ex post facto como "uma investigação sistemática e empírica na qual o pesquisador não tem controle direto sobre as variáveis independentes, porque já ocorreram suas manifestações ou porque são intrinsecamente não manipuláveis.” Em se tratando de Identidade, trabalho e consumo como variáveis, evidencia-se a impossibilidade de um estudo 
experimental, dada a natureza do objeto de pesquisa em questão.

O intuito desta pesquisa é de reconstruir a Identidade Social e encontrar nela um padrão que explique como é afetada pelas relações de consumo e de produção dentro do trabalho bancário. Neste sentido, pode-se caracterizar este estudo como Descritivo.

Foi feito um Corte Transversal na coleta de dados, representando "um instantâneo de um determinado momento" (COOPER; SCHINDLER, 2003, p. 129). Esclarece-se que apesar da Identidade não ser uma variável estática e estar sendo construída a cada instante, não se pretendeu captar sua transformação ao longo do tempo, mas sim sua atual construção a partir do ideário do entrevistado, de forma pontual.

As coletas de dados foram realizadas no próprio ambiente de trabalho (Ambiente de campo) e, necessariamente, pressupõe-se uma percepção de Rotina Modificada (COOPER; SCHINDLER, 2003). Entretanto, esperou-se poder corrigir parte do problema gerado pela rotina modificada por meio da construção do instrumento de coleta de dados, especificamente, pelas questões semi-estruturadas feitas aos indivíduos e aos grupos.

\subsection{EstratÉGIA DE COLETA DE DADOS}

Em consonância com a abordagem adotada, optou-se por realizar entrevistas individuais semiestruturadas e o focus group com bancários, como alternativas indicadas para proceder à coleta de dados. Segundo Gil (1988) as vantagens da entrevista são de possibilitar a obtenção de dados referentes aos mais amplos aspectos da vida social do entrevistado, obtenção de dados mais profundos sobre o comportamento humano e a possibilidade de classificação e quantificação dos dados obtidos. Segundo Cooper e Schindler (2003, p.133) um focus group ou "grupo de foco é um painel de pessoas, lideradas por um moderador treinado, que se reúne por um período de 90 minutos a duas horas. O facilitador moderador usa princípios de dinâmica de grupo para focar ou guiar o grupo na troca de idéias, sentimentos e experiências em um tópico específico."

As entrevistas permitem uma análise da Identidade Social de forma individualizada e o focus group nos ajuda na construção de uma visão mais coletivizada sobre tema, por permitir que os bancários discutam sobre a sua Identidade em conjunto. Durante o focus group, os resultados das entrevistas foram discutidos com os bancários para que possam acrescentar aquilo que 
compreendem como aspectos da Identidade Social que realmente correspondem à realidade vivenciada por eles.

Como salientado anteriormente, a base empírica para o estudo é o "texto", na concepção de Flick (2004) proveniente da narrativa e do discurso construído por meio das estratégias de coletas de dados.

\subsubsection{Universo da pesquisa}

Fazem parte do Universo desta pesquisa os trabalhadores do setor bancário, sejam eles funcionários de Instituições de natureza pública ou privada ${ }^{8}$, que ocupem funções descritas como atividades-fim bancárias. Desta forma, excluem-se do universo todos os funcionários de atividades intermediárias, terceirizados e estagiários.

\subsubsection{Unidade de análise}

A unidade de análise da pesquisa é o indivíduo por meio da construção do seu discurso, na expressão dos conceitos que tem de si e dos outros, manifesta a sua Identidade Social. Entretanto, para a compreensão dos elementos que dizem respeito a construção social do conceito de Identidade, a análise e compreensão dos discursos era feita de forma coletiva, procurando extrair os elementos subjetivos que foram objetivados pelos entrevistados, por meio de suas tipificações.

\subsubsection{Operacionalização do conceito de Identidade}

O conceito de Identidade será operacionalizado com base nas diversas definições feitas pelos autores discutidos no referencial teórico desta pesquisa. Primeiramente a Identidade está sendo entendida como fruto do discurso do entrevistado (SPINK E FREZZA, 1999) perante uma relação social (WoODWARD, 2000). Ao manifestar sobre quem ele é perante o outro, o

\footnotetext{
${ }^{8}$ Para efeitos dessa pesquisa, está-se utilizando a categorização da FEBRABAN (2008) para classificação dos bancos, sendo que estes são separados apenas entre públicos e privados, no que diz respeito à configuração jurídica da instituição.
} 
entrevistado expressa sua Identidade Social. Além disso, o conceito de Woodward (2000) é utilizado no sentido de entender que a Identidade é relacional e se manifesta na afirmação ou na negação do outro. Por isso, não se trabalhará apenas na concepção que o indivíduo tem de si, mas também na visão que tem do outro.

Outro marco importante para a operacionalização do constructo é a concepção de tipificação ${ }^{9}$, utilizada por Berger e Luckman (1985) e comungada por Spink e Frezza (1999). Esclarece-se que, segundo Berger e Luckmann (1985), as tipificações são esquemas referenciais para o indivíduo do que é a realidade, de quem somos e de quem é o outro. Segundo os autores: "A realidade da vida cotidiana contém esquemas tipificadores em termos dos quais os outros são apreendidos, sendo estabelecidos os modos como 'lidamos' com eles nos encontros face a face.” (BERGER; LUCKMANN, 1985, p. 49).

Spink e Frezza (1999, p. 25), comentando o trabalho de Berger e Luckman (1985), expressam que "A partir do conceito de tipificação, eles propõem que a sociedade é um produto humano (ou seja, a realidade é construída socialmente) [...] a base da realidade da vida cotidiana são as interações face-a-face em que o outro é apreendido a partir de esquemas tipificadores."

As tipificações são importantes, pois a Identidade pode se objetivar para o indivíduo quando ele se identificar com tais tipificações. Berger e Luckmann (1985, p. 125) afirmam que: "Finalmente, a própria Identidade (o eu total, se preferirmos) pode ser reificada, tanto a do indivíduo quanto a dos outros. Há então uma identificação total do indivíduo com as tipificações que lhe são atribuídas."

Como descrito por Aktouf (1998), os processos de identificação são importantes para a compreensão da Identidades dos sujeitos. Neste sentido, as identificações serão incorporadas

\footnotetext{
${ }^{9}$ O conceito de tipificação de Berger e Luckmann (1985) utilizado nesta pesquisa possui relações atávicas com o conceito de "tipo ideal" weberiano. Alfred Schultz, de quem Peter Berger era contemporâneo, se inspirou no conceito weberiano ao tecer suas considerações sobre a construção do conhecimento. A diferença entre o tipo ideal weberiano e a tipificação de Berger e Luckman (1985) é que o primeiro parte de uma concepção idealizada e pura não existente na realidade, enquanto que a segunda é realidade subjetiva objetivada coletivamente.
} 
como elementos constituidores das Identidades.

Este estudo apropria-se também da definição de Ciampa (2005) de que Identidade é verbo, é ação. Ao se reconstruir a fala dos entrevistados sobre as categorias de análise, priorizou-se a ação que ele expressa dentro das definições das categoria de análise "Ser Trabalhador" e "Ser Consumidor".

\subsubsection{Instrumentos de pesquisa}

O instrumento principal para coleta de dados foi o roteiro de entrevista semi-estruturada, que procurou identificar as tipificações feitas pelos bancários sobre o trabalhador e o consumidor, tanto como auto-referência quanto a partir da alteridade. Ou seja, foram descritas como são as tipificações que o bancário faz de si mesmo como trabalhador e como consumidor e do outro como trabalhador e como consumidor.

A entrevista também permitiu reconstruir descrições do trabalho, do consumo e do consumidor para o bancário. A partir das tipificações, procurou-se, por meio do tratamento dos dados, elencar os principais elementos que servem como referência identitária e categorizá-los segundo os critérios dos próprios bancários. Isto permitiu avaliar, a partir do discurso do bancário, os elementos que compõem sua Identidade com mais ênfase nos elementos da dicotomia consumo-produção.

Frisa-se que o processo de entrevista é um processo direto de interação social em que os discursos produzidos face-a-face permitem reconstruir parte das concepções tipificadoras dos entrevistados. É através da fala que os aspectos subjetivos se cristalizam e se objetivam para o indivíduo. Berger e Luckmann (1985, p. 57-58) comentam:

Falo como penso e o mesmo faz meu interlocutor na conversa. Ambos ouvimos o que cada qual diz virtualmente no mesmo instante, o que torna possível o contínuo, sincronizado e recíproco acesso às nossas duas subjetividades, uma aproximação intersubjetiva na situação face a face que nenhum outro sistema de sinais pode reproduzir. Mais ainda, ouço a mim mesmo à medida que falo. Meus próprios significados subjetivos tornam-se objetiva e continuamente alcançáveis por mim e ipso facto passam a ser "mais reais" para mim.

Os autores ainda acrescentam que é na relação de linguagem com o outro que o seu "ser" se objetiva e se torna alcançável para si e para o outro.

Ora, ao objetivar meu próprio ser por meio da linguagem meu próprio ser torna-se maciça e continuamente acessível a mim, ao mesmo tempo em que se torna assim alcançável pelo outro, e posso espontaneamente responder a esse ser sem a "interrupção" da reflexão deliberada. Pode-se dizer por conseguinte que a linguagem faz "mais real" minha subjetividade não somente para meu 
interlocutor mas também para mim mesmo. Esta capacidade da linguagem de cristalizar e estabilizar para mim minha própria subjetividade é conservada (embora com modificações) quando a linguagem se destaca da situação face a face. Esta característica muito importante da linguagem é bem retratada no ditado que diz deverem os homens falarem de si mesmos até se conhecerem a si mesmos. (BERGER E LUCKMANN, 1985, p. 58).

O roteiro de entrevista foi construído em dez sessões. A primeira sessão objetiva determinar informações pessoais e comportamentais do indivíduo de forma introdutória, tendo como objetivo situar o indivíduo dentro do seu quadro de referência pessoal. A segunda sessão solicita dados funcionais e informações sobre o tempo de exercício profissional. Essa sessão teve como objetivo avaliar o tempo de contato do entrevistado com a organização, com a agência, com a profissão, além de situar o funcionário na estrutura da empresa e avaliar o grau de familiaridade com a tarefa executada. A terceira sessão aborda a visão que o bancário tem do próprio trabalho tendo como objetivo captar como ele compreende as suas tarefas e obrigações, procurando avaliar o grau de contato com clientes e com demais colegas de trabalho. A quarta sessão procura avaliar a consciência das transformações do trabalho por parte do bancário, traçando um paralelo entre o passado, o presente e o futuro. A quinta sessão aborda diretamente o trabalho e as visões que o funcionário tem sobre sua profissão e sobre as atividades que executa. A sexta sessão foca a organização e a imagem construída pelo bancário sobre ela, procurando também revelar os valores que permeiam a relação entre o profissional e a instituição. A sétima sessão trata da categoria profissional como um todo, solicitando ao entrevistado que elabore sua visão sobre o coletivo. A oitava sessão trabalhou diretamente as tipificações feitas pelos bancários sobre quem são eles, como trabalhadores e como consumidores, e quem são os outros, também como consumidores e como trabalhadores. A nona sessão procurou trabalhar, segundo a fala dos bancários, o que são o trabalho, o consumo e o consumidor para eles, procurando traçar um paralelo com a forma como cada funcionário se define.

No focus group também foi utilizado um roteiro de entrevista construído a partir da análise das informações coletadas nas entrevistas individuais. O objetivo do focus group foi de fechar os conceitos e resultados obtidos dentro de uma concepção coletiva do que foi entendida a Identidade Social associada ao trabalho e ao consumo.

\subsubsection{Pré-teste}

Foi realizado um pré-teste com o roteiro das entrevistas com o objetivo de avaliar a compreensão das perguntas, o tempo de entrevista e a reação dos respondentes. Quatro 
bancários participaram do pré-teste, sendo que as entrevistas destes não foram consideradas no escopo da pesquisa.

Após a aplicação do pré-teste percebeu-se a necessidade da alteração em algumas perguntas, pois a compreensão das mesmas por parte não condizia com a intenção da pesquisa. Também foram acrescentadas novas perguntas que foram sugeridas pelos próprios entrevistados no final de cada pré-teste.

\subsubsection{Tamanho da população}

Foram realizadas cinqüenta e cinco entrevistas com bancários. Entretanto, cinco entrevistas foram descartadas, pois os entrevistados mostraram baixo envolvimento com o processo de coleta de dados, ora não respondendo grande parte das perguntas, ora respondendo de forma visivelmente displicente, em geral, preocupando-se mais com o tempo do que com a construção de suas falas.

Seis bancários participaram do focus group. Inicialmente foram convidados oito bancários. Entretanto, dois não compareceram, sendo que justificaram suas ausências posteriormente em função de questões associadas ao trabalho. Optou-se por convidar bancários que não participaram das entrevistas, entendendo que uma segunda perturbação a um mesmo grupo de bancários poderia resultar em baixo envolvimento ou indução nas respostas.

\subsubsection{O processo de coleta de dados}

Todas as entrevistas foram realizadas no próprio ambiente de trabalho dos entrevistados. A maioria das entrevistas aconteceram em ambientes isolados dos demais bancários. Entretanto, em função da característica de algumas agências, os funcionários responderam em seus próprios locais de trabalho. A todos os entrevistados foi garantido o sigilo tanto de seu nome quanto de sua instituição.

As entrevistas aconteceram todas em horário não comercial, ora antes da agência abrir ora depois do expediente bancário. Outro ponto relevente é que as entrevistas forma realizadas, em sua grande maioria, nas segundas quinzenas de cada mês, também por motivos de disponibilidade. Duraram entre uma hora e dez minutos e uma hora e trinta minutos.

Iniciou-se o processo de coleta de dados em uma agência de um banco privado com a 
anuência e total colaboração da gerência para a realização da pesquisa, desde que fosse garantido o sigilo do nome da instituição e dos entrevistados. Nesta agência, foram realizadas vinte e duas entrevistas consideradas válidas. Efetivamente, todos os bancários da agência foram entrevistados, exceto os que estavam afastados ou de férias. Na medida em que as entrevistas foram se realizando, percebeu-se que características específicas da instituição estavam influenciado diretamente o resultado de algumas respostas.

Optou-se, então, por outra instituição, desta vez de natureza pública, parar entrevistar os bancários. Também com a anuência e colaboração do gerente, as entrevistas foram realizadas contemplando a maioria dos bancários da agência. Dessa agência, obteve-se dezesseis entrevistas válidas. Observou-se também que características específicas da organização estavam afetando parte das respostas dos entrevistados, principalmente em relação à função social exercida pelo banco.

Como forma de avaliar os bancários de outras instituições, optou-se por diversificar o grupo de respondentes, compondo-os a partir de instituições diferentes. Os demais doze entrevistados válidos foram escolhidos de sete outras instituições, sendo cinco privadas e duas públicas. Relata-se que tal diversificação foi de suma importância para a validação de algumas conclusões realizadas nesta pesquisa.

O focus group foi realizado em um ambiente fora do cotidiano laboral dos entrevistados. Participaram entrevistados de três instituições bancárias diferentes, sendo duas privadas e uma pública.

\subsection{TÉCNICA DE TRATAMENTO DOS DADOS}

Os dados foram tratados pela análise de conteúdo que, segundo Bardin (1977, p. 42), é:

um conjunto de técnicas de análise de comunicação visando a obter, por procedimentos sistemáticos e objetivos de descrição do conteúdo das mensagens, indicadores (quantitativos ou não) que permitam a inferência de conhecimentos relativos às condições de produção/recepção destas mensagens.

Para Bardin (1977) a análise de conteúdo possui uma função essencial nos estudos exploratórios, pois dá profundidade à análise de textos e mensagens que eram pouco exploradas em termos de profundidade, sempre de uma forma sistemática.

A análise de conteúdo será realizada em três etapas básicas: a pré-análise, a exploração do 
material e o tratamento dos resultados. Estas três etapas permitiram categorizar as falas dos entrevistados e situá-las dentro dessas categorizações.

As entrevistas foram transcritas e tabuladas de forma a captar, com base na fala de cada entrevistado os principais pontos que denotam a sua Identidade Social e os elementos associados a ela. Em seguida, a partir das falas individuais, procurar-se-á construir um perfil comum dos discursos que dê indicações de traços de como os aspectos do trabalho e do consumo estão afetando coletivamente as Identidades Sociais dos entrevistados. Ao mesmo tempo, as discussões feitas no focus group complementaram as informações obtidas pelas entrevistas individuais. 
3.3.1. Desenho da estratégia de coleta e tratamento de dados

\begin{tabular}{|l|c|c|}
\cline { 2 - 3 } \multicolumn{1}{c|}{} & \multicolumn{2}{c|}{ Tipificações $^{1}$} \\
\cline { 2 - 3 } \multicolumn{1}{c|}{} & Trabalhador & Consumidor \\
\hline Eu & Eu - trabalhador & Eu - consumidor \\
\hline Outro & Colega de trabalho & Consumidor \\
\hline
\end{tabular}

\begin{tabular}{|c|}
\hline Etapas da pesquisa \\
\hline $1^{\circ}$ Passo - Entrevistas Semi- \\
estruturadas \\
(Coleta de Dados) \\
\hline
\end{tabular}
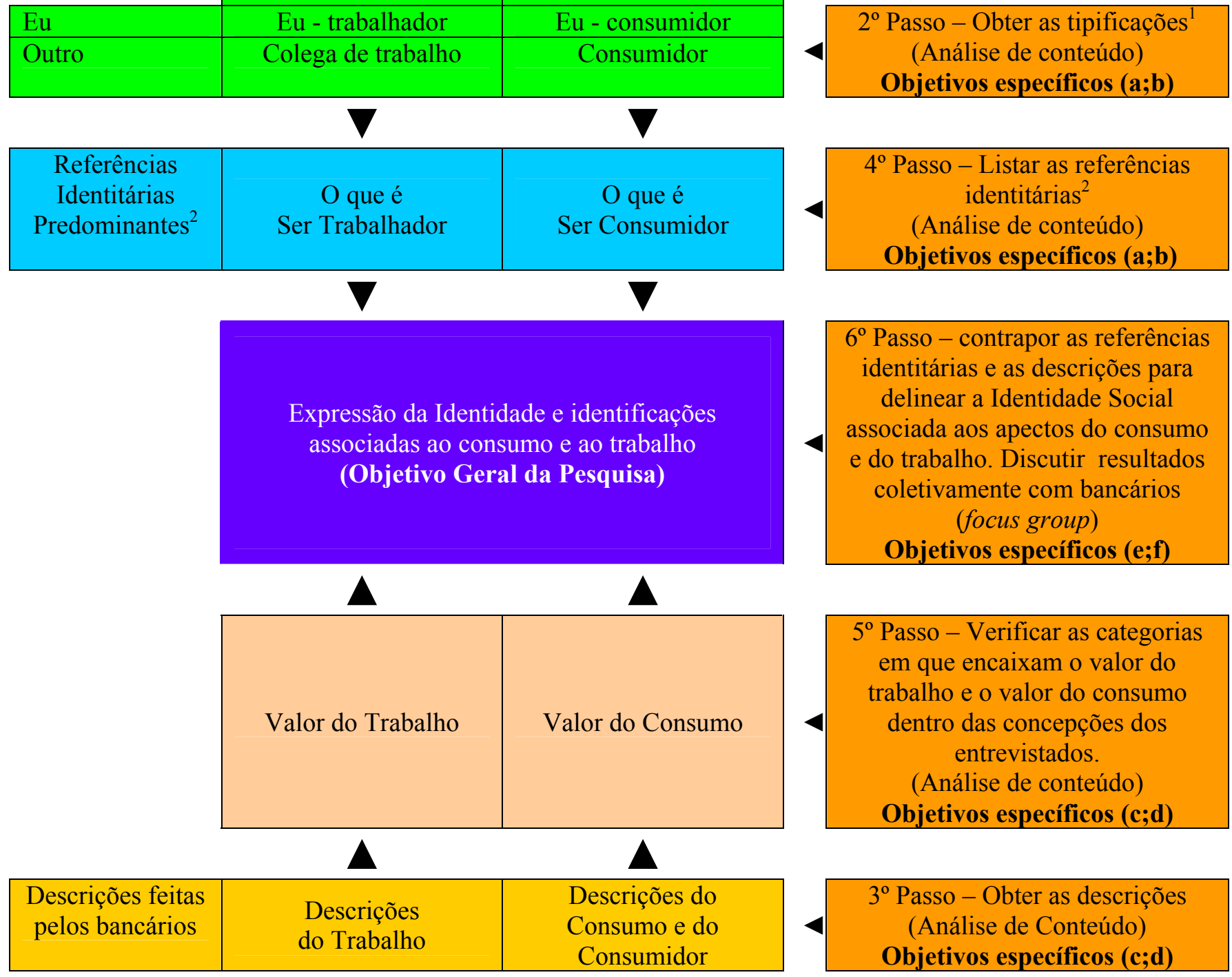

\section{Objetivos específicos $(\mathbf{a} ; \mathbf{b})$}

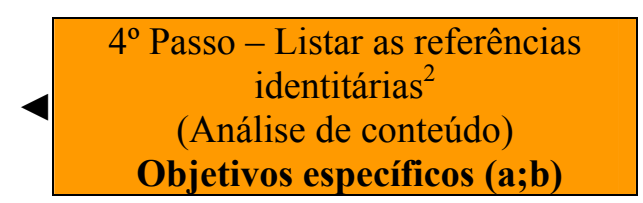

Objetivos específicos $(\mathbf{a} ; \mathbf{b})$

$6^{\circ}$ Passo - contrapor as referências

identitárias e as descrições para

delinear a Identidade Social

associada aos apectos do consumo

e do trabalho. Discutir resultados

coletivamente com bancários (focus group)

Objetivos específicos (e;f)

$5^{\circ}$ Passo - Verificar as categorias em que encaixam o valor do trabalho e o valor do consumo dentro das concepções dos entrevistados.

(Análise de conteúdo) Objetivos específicos $(\mathbf{c} ; \mathbf{d})$

\section{Figura 3 - Estratégia da coleta e tratamento de dados}

Notas: 1- Conceito segundo Berger e Luckmann (1985);

2 - Trabalhado segundo o conceito de Ciampa (2005);

\subsubsection{Categorias de análise}

A análise dos discursos dos entrevistados foi organizada em categorias, de forma que se pudesse observar, ao longo das falas, elementos que caracterizassem os sentidos dados às suas frases, permitindo classificações, de acordo com os objetivos de pesquisa. No decorrer do 
processo de análise, diversas perguntas do roteiro de entrevista são utilizadas para extrair as informações que compõem as categorias. Em cada categoria, partiu-se da própria fala dos entrevistados para encontrar os elementos que permitissem as classificações, ou seja, partiu-se da fala dos trabalhadores para encontrar os elementos que servissem como classificadores de seus discursos. Ao todo, dez categorias foram utilizadas para interpretar os dados, as quais descrevemos a seguir.

a) Categoria "Visão sobre as transformações do contexto": nesta categoria, procurou-se identificar como os entrevistados descreviam as mudanças acontecidas no setor, qualificandoas dentro de seus próprios critérios de análise. Procurou-se obter não somente uma visão do presente em relação ao passado, mas uma projeção para o futuro de tais funcionários. Esta categoria é de análise secundária, servindo apenas para compreender parte dos dados e avaliar a compreensão dos respondentes sobre as transformações ocorridas no setor.

b) Categoria "Valor do Trabalho": nesta categoria, procurou-se, ao longo da fala dos entrevistados, identificar qual é o valor dado ao trabalho, ou seja, procura definir qual é a importância que é atribuída a ele.

c) Categoria "Valor do Consumo": procurou-se depreender qual é a importância, ou valor, dado ao consumo pelos entrevistados. De forma semelhante, o consumo será compreendido na forma como se posiciona dentro do discurso do entrevistado.

d) Categoria "Ser Trabalhador": quer-se entender nesta categoria como os entrevistados descrevem o Ser Trabalhador, que no caso é ser bancário, bem como entender quais valores estão associados a ele. Essa categoria incorpora a visão que os bancários tem de si mesmos e dos demais bancários, seus colegas de organização ou de outras instituições.

e) Categoria "Ser Consumidor": da mesma forma que na categoria anterior, procura-se descobrir como os respondentes descrevem o ser-consumidor. Para esta categoria, balizou-se na visão que o entrevistado tem de si mesmo, do seu cliente e dos demais consumidores que não necessariamente são seus clientes.

f) Categoria "Elementos de Expressão da Identidade Social": a pergunta chave desta categoria é saber o que o bancário utiliza, dentre os elementos estudados, como referência para exprimir sua Identidade. Procura obter dentre os elementos com os quais os entrevistados se identificam, estabelecendo relações com os elementos identitários. Essa categoria de 
análise serve para estabelecer relações nos discursos dos entrevistados e se subdivide nas subcategorias:

i. "Expressão da Identidade, identificação e trabalho": tal categoria tem o objetivo de verificar até que ponto o trabalho é utilizado de forma associada à expressão de sua Identidade, além de compreender seus vínculos com sua atividade laboral;

ii. "Expressão da Identidade, identificação e categoria profissional”: procura avaliar como a categoria profissional está relacionada com os processos de expressão da Identidade;

iii. "Expressão da Identidade, identificação e organização": Analisa como a organização está relacionada com os processos de expressão da Identidade e Identificação.

iv. "Expressão da Identidade, identificação e consumo": de forma análoga à categoria anterior, procura associações entre aspectos do consumo e a Identidade, bem como seus vínculos.

v. "Expressão da Identidade, identificação e consumidor": procura explorar como o consumidor afeta e quais são os vínculos que o entrevistado estabelece.

As categorizações são sempre cortes que são feitos nas falas. Entretanto, esclarece-se que se procurou utilizar cada fala dentro de seu contexto, no discurso proferido.

\subsection{DESCRIÇÃO GERAL DA POPULAÇ̃̃O ENTREVISTADA}

Reitera-se que num estudo qualitativo não há a intenção de se criar generalizações sobre as informações pesquisadas. Por isso mesmo, não há obrigatoriedade de se constituir uma base de dados representativa do Universo da pesquisa. Pelo contrário, em alguns estudos qualitativos é comum utilizar-se de parte da população que está fora dos padrões de 
normalidade estatística para compreender e explicar elementos que afetam a população como um todo.

Nesta pesquisa procurou-se ter um grupo de entrevistados que pudesse variar em suas características demográficas e funcionais, bem como oriundos de instituições ${ }^{10}$ com características econômicas diferentes, sendo que a variedade e a dispersão de tais características está sendo entendida como uma forma de abrir o escopo de análise. À medida em que se encontra um padrão comum no discurso proveniente de entrevistados com características distintas, entende-se que se obteve elementos que denotem uma objetivação de conceitos, tal qual como foi descrita por Berger e Luckmann(1985). Por isso, faz-se necessário compreender que as características do grupo de entrevistados, não visam comprovar o seu grau de similaridade ao Universo pesquisado, mas compreender sua diversidade.

Esclarece-se que as características que são expostas neste item não foram alvo de estudos correlacionais, por não ser objetivo desta pesquisa e pelo fato de a amostra não ter a intenção de ser representativa.

\subsubsection{Características demográficas}

No que tange ao gênero dos entrevistados, 30 são do sexo masculino e 20 do sexo feminino, sendo que há representantes dos respectivos gêneros em todas as demais características, como faixas etárias distintas, nível de instrução formal, estado civil dentre outros. Vide Tabela 2 abaixo para detalhamento das informações sobre gênero.

\footnotetext{
${ }^{10}$ Como foi descrito no item $O$ processo de coleta de dados deste capítulo.
} 
Tabela 2 - Distribuição dos respondentes da pesquisa por gênero - dados coletados nas agências bancárias de julho a outubro de 2007

\begin{tabular}{l|c|c}
\hline Categorias & Quantidade & Freqüência \\
\hline Masculino & 30 & $60 \%$ \\
Feminino & 20 & $40 \%$ \\
\hline Total & $\mathbf{5 0}$ & $\mathbf{1 0 0} \%$ \\
\hline \hline
\end{tabular}

Fonte: Dados de pesquisa

No que diz respeito à faixa etária dos entrevistados, observa-se que há representantes nas diversas faixas etárias. Entretanto, não se conseguiu nas agências pesquisadas de natureza privada, bancários acima dos cinqüenta anos. A Tabela 3 detalha a distribuição dos entrevistados por idade.

Tabela 3 - Distribuição dos respondentes da pesquisa por idade - dados coletados nas agências bancárias de julho a outubro de 2007

\begin{tabular}{l|c|c}
\hline \hline Intervalo de Classe & Quantidade & Freqüência \\
\hline $20-\mid 25$ & 06 & $12 \%$ \\
$25-\mid 30$ & 16 & $32 \%$ \\
$30-\mid 35$ & 06 & $12 \%$ \\
$35-\mid 40$ & 06 & $12 \%$ \\
$40-\mid 45$ & 11 & $22 \%$ \\
$45-\mid 50$ & 04 & $08 \%$ \\
$50-\mid 55$ & 01 & $02 \%$ \\
\hline Total & $\mathbf{5 0}$ & $\mathbf{1 0 0} \%$ \\
\hline
\end{tabular}

Fonte: Dados de pesquisa

Sobre a instrução formal dos respondentes, percebe-se que o nível de escolaridade é elevado. Dos 50 entrevistados, 46 estão cursando ou já possuem curso superior. Os demais desistiram de um curso superior que estava em andamento em função de questões associadas ao trabalho bancário, tais como ter que mudar de agências/cidades constantemente ou incompatibilidade com o horário de trabalho. Dentre as falas dos entrevistados, pode-se perceber que se trata da estratégia de alguns bancos privados realizar captações somente em universidades, visando jovens em início de carreira, o que pode, em parte, explicar os dados. A Tabela 4 discrimina as informações sobre a instrução formal.

Tabela 4 - Distribuição dos respondentes da pesquisa por grau de instrução formal dados coletados nas agências bancárias de julho a outubro de 2007

\begin{tabular}{l|c|c}
\hline \hline Categorias & Quantidade & Freqüiência \\
\hline Superior Incompleto & 04 & $08 \%$ \\
Cursando superior & 08 & $16 \%$ \\
Superior completo & 28 & $56 \%$ \\
Especialização & 10 & $20 \%$ \\
\hline Total & $\mathbf{5 0}$ & $\mathbf{1 0 0} \%$ \\
\hline \hline
\end{tabular}

Fonte: Dados de pesquisa 
Mais da metade dos entrevistados é composta por casados, sendo que destes 26 possuem filhos. Há 17 solteiros entre os entrevistados e uma minoria de divorciados (02) e viúvos (01). A Tabela 5 a seguir expõe os dados.

Tabela 5 - Distribuição dos respondentes da pesquisa por estado civil - dados coletados nas agências bancárias de julho a outubro de 2007

\begin{tabular}{l|c|c}
\hline Categorias & Quantidade & Freqüência \\
\hline Solteiros & 17 & $34 \%$ \\
Casados & 30 & $60 \%$ \\
Divorciados & 02 & $04 \%$ \\
Viúvos & 01 & $02 \%$ \\
\hline Total & $\mathbf{5 0}$ & $\mathbf{1 0 0} \%$ \\
\hline \hline
\end{tabular}

Fonte: Dados de pesquisa

\subsubsection{Características funcionais}

A maior parte dos entrevistados descreveu seu cargo como de gerência intermediária, representando 28 entrevistados. Entretanto, cabe explicar que a grande maioria destes de cargo intermediário está classificada como gerente de relacionamento, ou seja, gestor de contas de clientes. Não há nenhum subordinado sob a gestão destes funcionários. A função principal destes é atender o cliente e vender produtos. Entretanto, são cargos comissionados e descritos como se fossem cargos gerencias. Os 18 bancários no nível operacional executam funções de caixa, técnico bancário ou escriturário. Os gerentes de agência, que também executam funções de atendimento a clientes, totalizam quatro entrevistados. A Tabela 6 detalha os dados.

Tabela 6 - Distribuição dos respondentes da pesquisa por nível hierárquico do cargo ocupado - dados coletados nas agências bancárias de julho a outubro de 2007

\begin{tabular}{l|c|c}
\hline \hline Categorias & Quantidade & Freqüência \\
\hline Gerente de agência & 04 & $08 \%$ \\
Gerente Intermediário & 28 & $56 \%$ \\
Operacional & 18 & $36 \%$ \\
\hline Total & $\mathbf{5 0}$ & $\mathbf{1 0 0} \%$ \\
\hline
\end{tabular}

Fonte: Dados de pesquisa

A grande maioria dos entrevistados, 43 bancários, tem até cinco anos no cargo atual. Quatro bancários têm entre cinco e dez anos e dois funcionários têm entre dez e quinze anos. Apenas um funcionário tem entre 15 e 20 anos, sendo que este sempre assumiu a função de caixa. A Tabela 7 expõe estes dados. 
Tabela 7 - Distribuição dos respondentes por tempo no atual cargo - dados coletados nas agências bancárias de julho a outubro de 2007

\begin{tabular}{l|c|c}
\hline \hline Intervalo de Classe & Quantidade & Freqüência \\
\hline $00-\mid 05$ & 43 & $86 \%$ \\
$05-\mid 10$ & 04 & $08 \%$ \\
$10-\mid 15$ & 02 & $04 \%$ \\
$15-\mid 20$ & 01 & $02 \%$ \\
\hline Total & $\mathbf{5 0}$ & $\mathbf{1 0 0} \%$ \\
\hline \hline
\end{tabular}

Fonte: Dados de pesquisa

No que diz respeito ao tempo de organização, 24 expressam que estão na instituição atual em tempo igual ou inferior a cinco anos. Oito entrevistados situaram seu tempo de organização entre cinco e dez anos. Entre dez e quinze anos, enquadram-se cinco entrevistados e entre quinze e vinte anos dez bancários. Outros três funcionários possuem tempo superior a vinte de organização. Tais informações são relevantes, pois mostram que há entre os respondentes desde pessoas com pouco tempo de instituição até bancários com uma vasta experiência organizacional. A Tabela 8 detalha os dados sobre o tempo na atual instituição.

Tabela 8 - Distribuição dos respondentes por tempo na atual instituição - dados coletados nas agências bancárias de julho a outubro de 2007

\begin{tabular}{l|c|c}
\hline \hline Intervalo de Classe & Quantidade & Freqüência \\
\hline $00-\mid 05$ & 24 & $48 \%$ \\
$05-\mid 0$ & 08 & $16 \%$ \\
$10-\mid 15$ & 05 & $10 \%$ \\
$15-\mid 20$ & 10 & $20 \%$ \\
$20-\mid 25$ & 02 & $04 \%$ \\
$25-\mid 30$ & 01 & $02 \%$ \\
\hline Total & $\mathbf{5 0}$ & $\mathbf{1 0 0} \%$ \\
\hline
\end{tabular}

Fonte: Dados de pesquisa

Dentre entrevistados, 43 possuem até cinco anos na agência em que estão atualmente. Muitos destes revelaram que há uma prática comum, tanto em bancos públicos, privados ou de economia mista, de realizar rodízio de funcionários entre as agências em períodos de 04 a 05 anos, o que pode explicar esta característica da população. Apenas três respondentes têm mais de quinze anos na mesma agência. A Tabela 9 apresenta tais informações. 
Tabela 9 - Distribuição dos respondentes por tempo na atual agência - dados coletados nas agências bancárias de julho a outubro de 2007

\begin{tabular}{l|c|c}
\hline \hline Intervalo de Classe & Quantidade & Freqüência \\
\hline $00-\mid 05$ & 43 & $86 \%$ \\
$05-\mid 10$ & 04 & $08 \%$ \\
$10-\mid 15$ & 00 & $00 \%$ \\
$15-\mid 20$ & 02 & $04 \%$ \\
$20-\mid 25$ & 01 & $02 \%$ \\
\hline Total & $\mathbf{5 0}$ & $\mathbf{1 0 0} \%$ \\
\hline \hline
\end{tabular}

Fonte: Dados de pesquisa

Uma parcela considerável, 20 entrevistados, já trabalhou em outras organizações bancárias e 30 bancários só tiveram contato com o trabalho bancário na instituição que estão atualmente. Dentre os que já trabalharam em outras instituições bancárias, encontram-se tanto funcionários de instituições públicas ou privadas. Seguem as informações na Tabela 10.

Tabela 10 - Distribuição dos respondentes da pesquisa por resposta à pergunta "Trabalhou em outros bancos?" - dados coletados nas agências bancárias de julho a outubro de 2007

\begin{tabular}{l|c|c}
\hline Categorias & Quantidade & Freqüência \\
\hline Sim & 20 & $40 \%$ \\
Não & 30 & $60 \%$ \\
\hline Total & $\mathbf{5 0}$ & $\mathbf{1 0 0} \%$ \\
\hline
\end{tabular}

Fonte: Dados de pesquisa

Em termos de tempo total como bancário, 15 respondentes têm até cinco anos de experiência. Entre cinco e dez anos, são oito funcionários. Ressalta-se que 27 bancários têm mais de dez anos de profissão, o que pode ser entendido como uma parcela que possui um tempo significativo trabalhando no setor. A Tabela 11 detalha tais informações.

Tabela 11 - Distribuição dos respondentes por tempo total como bancário - dados coletados nas agências bancárias de julho a outubro de 2007

\begin{tabular}{l|c|c}
\hline \hline Intervalo de Classe & Quantidade & Freqüência \\
\hline $00-\mid 05$ & 15 & $30 \%$ \\
$05-\mid 10$ & 08 & $16 \%$ \\
$10-\mid 15$ & 08 & $16 \%$ \\
$15-\mid 20$ & 10 & $20 \%$ \\
$20-\mid 25$ & 05 & $10 \%$ \\
$25-$ & 04 & $08 \%$ \\
\hline Total & $\mathbf{5 0}$ & $\mathbf{1 0 0} \%$ \\
\hline \hline
\end{tabular}

Fonte: Dados de pesquisa

Todos os entrevistados responderam que têm contato direto com o cliente na execução de suas tarefas. Neste sentido, não há, entre os entrevistados, funcionários que trabalhem exclusivamente em setores de suporte administrativo, uma vez que se entende que o contato 
com o cliente é considerado como importante para este estudo (Vide Tabela 12).

Tabela 12 - Distribuição dos respondentes da pesquisa por resposta à pergunta "Na execução do trabalho, tem contato com cliente?" - dados coletados nas agências bancárias de julho a outubro de 2007

\begin{tabular}{l|c|c}
\hline Categorias & Quantidade & Freqüîncia \\
\hline Sim & 50 & $100 \%$ \\
Não & 00 & $00 \%$ \\
\hline Total & $\mathbf{5 0}$ & $\mathbf{1 0 0} \%$ \\
\hline \hline
\end{tabular}

Fonte: Dados de pesquisa

No que diz respeito a contato com outros funcionários na execução do trabalho, a maioria, 48 bancários, afirma que sim e dois entrevistados dizem que não (Vide Tabela 13).

Tabela 13 - Distribuição dos respondentes da pesquisa por resposta à pergunta "Na execução do trabalho, tem contato com outros funcionários?" - dados coletados nas agências bancárias de julho a outubro de 2007

\begin{tabular}{l|c|c}
\hline Categorias & Quantidade & Freqüência \\
\hline Sim & 48 & $94 \%$ \\
Não & 02 & $04 \%$ \\
\hline Total & $\mathbf{5 0}$ & $\mathbf{1 0 0} \%$ \\
\hline
\end{tabular}

Fonte: Dados de pesquisa

\subsubsection{Dados das organizações às quais os entrevistados fazem parte}

Como foi exposto, garantiu-se aos entrevistados que o nome da instituição bem como dados que pudessem as identificar não seriam expostos. Neste sentido, não são apresentados dados individuais das Instituições, procurando apenas posicioná-las no setor. Os dados dos entrevistados e de suas instituições de origem são comparados com os dados do setor, principalmente em termos de número de agências e $\mathrm{PABs}^{11}$.

Reitera-se que não se intenciona delinear representatividade da população frente ao universo da pesquisa.

\footnotetext{
${ }^{11}$ Esclarece-se que não se conseguiu obter dados precisos e atuais da quantidade de funcionários em cada umas das classificações da FEBRABAN (2008). Neste sentido, trabalhou-se com o número de agências e postos avançados bancários na pressuposição de que instituições com maior quantidade de unidades destes elementos devem ter maior quantidade de funcionários em seus quadros.
} 
Segundo dados da FEBRABAN (2008), há no Brasil 154 bancos $^{12}$ com agências em funcionamento, totalizando 18.516 agências bancárias e 38.358 PABs.

Os nove bancos que possuem funcionários que participam da pesquisa estão entre os 15 maiores bancos em números de agência e entre os 20 maiores bancos somando-se agências e os Postos Avançados Bancários. Juntos, os bancos representam 84,11\% do número total de agências e $92,12 \%$ dos PABs. Tais informações mostram que os funcionários entrevistados fazem parte de instituições que lidam com uma quantidade significativa de bancários em seus quadros pessoais.

Segundo dados da FeBRABAN (2008), há no Brasil 12 bancos públicos e 142 de natureza privada (Vide Tabela 14). Entretanto, quando são analisadas os números de agências bancárias e PABs (Vide Tabela 15 e Tabela 16), pode-se perceber uma participação maior dos bancos públicos no contexto geral do setor.

Tabela 14 - Distribuição dos bancos no Brasil segundo a natureza econômica da instituição em Fevereiro de 2008.

\begin{tabular}{l|c|c}
\hline \hline Natureza econômica & Quantidade & Freqüência \\
\hline Públicos & 12 & $07,79 \%$ \\
Privados & 142 & $92,21 \%$ \\
\hline Total & $\mathbf{1 5 4}$ & $\mathbf{1 0 0 \%}$ \\
\hline \hline
\end{tabular}

Fonte: FEBRABAN (2008)

Tabela 15 - Distribuição dos bancos em número de agências no Brasil segundo a natureza econômica da instituição em Fevereiro de 2008.

\begin{tabular}{l|c|c}
\hline \hline Natureza Econômica & Quantidade & Freqüência \\
\hline Agências de Bancos Públicos & 7.956 & $42,97 \%$ \\
Agências de Bancos Privados & 10.560 & $57,03 \%$ \\
\hline Total & $\mathbf{1 8 . 5 1 6}$ & $\mathbf{1 0 0 \%}$ \\
\hline
\end{tabular}

Fonte: FEBRABAN (2008)

12 Dentre os 154 bancos, alguns são partes de conglomerados pertencentes a outros bancos. Desta forma, contando-se somente os conglomerados, há no Brasil 124 bancos segundo a FEBRABAN (2008). 
Tabela 16 - Distribuição dos bancos em número de postos avançados bancários no Brasil segundo a natureza econômica da instituição em Fevereiro de 2008.

\begin{tabular}{|c|c|c|}
\hline Natureza econômica & Quantidade & Freqüência \\
\hline Postos Avançados Bancários de Bancos Públicos & 15.908 & $41,47 \%$ \\
\hline Postos Avançados Bancários de Bancos Privados & 22.450 & $58,53 \%$ \\
\hline Total & 38.358 & $100 \%$ \\
\hline
\end{tabular}

Fonte: FEBRABAN (2008)

Dos 50 entrevistados desta pesquisa, 30 são provenientes de empresa privada, sendo que 22 destes são da mesma instituição, compreendendo uma agência inteira. Os demais oito bancários são de seis outros bancos privados distintos. Vinte bancários são de empresas públicas, sendo que 16 são de uma mesma agência e um de outro banco. A Tabela 17 expõe os dados.

Tabela 17 - Distribuição dos respondentes da pesquisa por natureza econômica das instituições em que trabalham atualmente - dados coletados nas agências bancárias de julho a outubro de 2007

\begin{tabular}{l|c|c}
\hline \hline Natureza Econômica & Quantidade & Freqüência \\
\hline Pública & 20 & $40 \%$ \\
Privada & 30 & $60 \%$ \\
\hline Total & $\mathbf{5 0}$ & $\mathbf{1 0 0} \%$ \\
\hline \hline
\end{tabular}

Fonte: Dados de pesquisa

Nota: A separação dos bancos segue a classificação feita pela FEBRABAN (2008)

No Brasil, predominam as Instituições de capital nacional, com 48,05\% das instituições, seguido das instituições nacionais de capital estrangeiro com $24,03 \%$ dos bancos. Os bancos públicos, sejam estaduais ou federais, representam apenas 7,8\% do número de instituições (Vide Tabela 18).

No que diz respeito ao número de agências, os bancos federais possuem a maior quantidade relativa $(36,17 \%)$, seguido dos bancos nacionais $(33,65 \%)$ e pelos bancos nacionais com controle estrangeiro $(18,15 \%)$.

Em termos de PABs, os bancos nacionais possuem maior percentual $(40,28 \%)$, sendo que os bancos federais estão um pouco abaixo com 34,07\% do total de agências. A Tabela 19 detalha mais tais informações. 
Tabela 18 - Distribuição dos bancos no Brasil segundo a nacionalidade da propriedade da instituição em Fevereiro de 2008

\begin{tabular}{l|c|c}
\hline \hline Nacionalidade da Propriedade & Quantidade & Freqüência \\
\hline Nacionais & 74 & $48,05 \%$ \\
Nacionais com participação de capital estrangeiro & 07 & $04,55 \%$ \\
Nacionais com controle acionário estrangeiro & 37 & $24,03 \%$ \\
Estrangeiros & 08 & $05,19 \%$ \\
Estaduais & 06 & $03,90 \%$ \\
Federais & 06 & $03,90 \%$ \\
Demais bancos não classificados pela FEBRABAN & 16 & $10,39 \%$ \\
\hline Total & $\mathbf{1 5 4}$ & $\mathbf{1 0 0 \%}$ \\
\hline \hline
\end{tabular}

Fonte: FEBRABAN (2008)

Tabela 19 - Distribuição dos bancos em quantidade de agências e postos avançados bancários no Brasil segundo a nacionalidade da propriedade da instituição em Fevereiro de 2008

\begin{tabular}{l|c|c|c|c}
\hline \multirow{2}{*}{ Nacionalidade da Propriedade } & \multicolumn{2}{|c|}{ Agências } & \multicolumn{2}{c}{ Postos Avançados } \\
\cline { 2 - 5 } & $\mathrm{n}$ & $\mathrm{f}$ & $\mathrm{n}$ & $\mathrm{f}$ \\
\hline Nacionais & 6.230 & $33,65 \%$ & 15.451 & $40,28 \%$ \\
Nacionais com participação de capital estrangeiro & 943 & $5,09 \%$ & 944 & $2,46 \%$ \\
Nacionais com controle acionário estrangeiro & 3.360 & $18,15 \%$ & 6.055 & $15,79 \%$ \\
Estrangeiros & 9 & $0,05 \%$ & 0 & $0,00 \%$ \\
Estaduais & 1.258 & $6,79 \%$ & 2.839 & $7,40 \%$ \\
Federais & 6.698 & $36,17 \%$ & 13.069 & $34,07 \%$ \\
Demais bancos não classificados pela FEBRABAN & 18 & $0,10 \%$ & 0 & $0,00 \%$ \\
\hline Total & $\mathbf{1 8 . 5 1 6}$ & & $\mathbf{3 8 . 3 5 8}$ & \\
\hline \hline
\end{tabular}

Fonte: FEBRABAN (2008)

Entre os entrevistados, não há representantes de instituições em propriedade de capital estrangeiro. Ressalta-se entretanto que o volume de profissionais destas instituições são significativamente pouco expressivos perante o setor como um todo. Ressalta-se também a baixa presença de representantes das instituições nacionais com participação de capital estrangeiro e de instituições estaduais. Há uma predominância muito forte de profissionais representantes de instituições nacionais com controle acionário estrangeiro (23 bancários) e de bancos federais (19 respondentes). Esta proporção foi afetada pela estratégia de coleta de dados assumida durante a pesquisa e que foi detalhada anteriormente. 
Tabela 20 - Distribuição dos entrevistados segundo a nacionalidade da propriedade do banco em Fevereiro de 2008

\begin{tabular}{l|c|c}
\hline \hline Nacionalidade da Propriedade & Quantidade & Freqüência \\
\hline Nacionais & 06 & $12 \%$ \\
Nacionais com participação de capital estrangeiro & 01 & $02 \%$ \\
Nacionais com controle acionário estrangeiro & 23 & $46 \%$ \\
Estrangeiros & 00 & $00 \%$ \\
Estaduais & 01 & $02 \%$ \\
Federais & 19 & $38 \%$ \\
Demais bancos não classificados pela FEBRABAN & 00 & $00 \%$ \\
\hline Total & $\mathbf{5 0}$ & $\mathbf{1 0 0 \%}$ \\
\hline \hline
\end{tabular}

Fonte: Dados de pesquisa

No que diz respeito à configuração do conjunto de entrevistados, acredita-se, ao avaliar todos os aspectos de seus representantes, que há pluralidade tanto em termos demográficos, funcionais quanto institucionais, permitindo uma análise do contexto no qual os bancários estão inseridos. 
Uma visão pós-moderna da questão: os dados são cubos cheios de números. Certa vez o pesquisador torturou os dados até que eles confessaram: só temos cinco lados. 


\subsection{VISÃO SOBRE AS TRANSFORMAÇÕES DO CONTEXTO}

A categoria de análise "Visão sobre as transformações do contexto" procura entender como os entrevistados, de forma coletiva, perceberam as transformações acontecidas no setor nos últimos anos e como vê a profissão no presente.

Sobre o passado, as respostas se dividem entre os que descrevem a profissão com uma visão positiva (29 entrevistados) e com visão negativa (21 respondentes). A Tabela 21 mostra tais informações.

Tabela 21 - Distribuição dos respondentes da pesquisa por resposta à pergunta "Como você vê a profissão de bancário no passado?"- dados coletados nas agências bancárias de julho a outubro de 2007

\begin{tabular}{l|c|c}
\hline Categorias & Quantidade & Freqüência \\
\hline Possuem uma visão positiva & 29 & $58 \%$ \\
Possuem uma visão negativa & 21 & $42 \%$ \\
\hline Total & $\mathbf{5 0}$ & $\mathbf{1 0 0} \%$ \\
\hline \hline
\end{tabular}

Fonte: Dados de pesquisa

Os que descrevem o passado de forma positiva, afirmam que antigamente havia mais status, a remuneração era melhor, havia menos pressão por parte do banco e dos clientes. O interessante é que esta visão se objetivou no coletivo dos bancários, pois até os que têm pouco tempo de casa descrevem da mesma forma.

A gente tem um pouco daquela idéia do bancário (nome do banco) de 30 anos. O quê que você vai ser meu filho? Médico ou trabalhar no (nome do banco)? Que era bem assim, eram pessoas com salários altíssimos. (Entrevistado 15).

Antigamente o bancário, ele tinha uma imagem, uma imagem de sucesso, de que quem fosse bancário, era como se diz, era um partidão, vamos dizer assim, e hoje isso vem mudando. (Entrevistado 19).

[...] antigamente tinha lá as metas para bater tranqüilas, a concorrência não era tão grande, então era bem mais tranqüilo trabalhar. (Entrevistado 20).

[...] eu vejo que antigamente o cliente necessitava do banco (depois) eu via que o banco é que precisava do cliente. (Entrevistado 25 ).

Como visão negativa, a profissão de bancário é descrita como acomodada e o trabalho como sendo muito manual e sem ferramentas que auxiliassem no processo de operação e gestão.

O bancário, ele era muito acomodado, naquilo que fazia, sem muita responsabilidade para com o consumidor final, não usava nada de empatia nas suas atribuições, porém não havia tanta reclamação como há hoje, por mais que hoje, os bancários se esforcem em atender melhor e se colocar no lugar do cliente.(Entrevistado 47). 
Nossa, eu sou da época que tudo era feito no relatório, no papel, na caneta, porque quando alguém chegava para fazer um depósito no banco, você recebia o depósito naquela maquininha arcaica que tinha antigamente, ai na sala, todos os depósito e cheques eram lançados à mão. (Entrevistado 30).

O presente, na resposta dos entrevistados, em geral é expresso como uma oposição ao passado. Por isso há uma semelhança, de forma invertida, entre a quantidade de visões positivas e negativas (Vide Tabela 22).

Tabela 22 - Distribuição dos respondentes da pesquisa por resposta à pergunta "Como você vê a profissão de bancário no presente?"- dados coletados nas agências bancárias de julho a outubro de 2007

\begin{tabular}{l|c|c}
\hline Categorias & Quantidade & Freqüência \\
\hline Possuem uma visão positiva & 23 & $46 \%$ \\
Possuem uma visão negativa & 27 & $54 \%$ \\
\hline Total & $\mathbf{5 0}$ & $\mathbf{1 0 0} \%$ \\
\hline \hline
\end{tabular}

Fonte: Dados de pesquisa

As visões negativas do presente são descritas em termos da diminuição do status e dos benefícios financeiros da profissão, a pressão por resultados em termos de vendas de produtos, o medo das demissões e as cobranças maiores dos clientes. Alguns também descreveram que aumentou a competitividade entre os bancários.

No passado você pode falar que num tinha uma cobrança, uma missão e um cumprimento de metas. É complicado hoje. Mudou muito, você têm tudo automatizado. Você deixa de ter vários papéis na tua mesa, é bem sistema, só que em relação ao seu tempo, é precioso. Hoje eu não posso ficar com cliente na minha mesa, nem pode fumar um cigarro contando da vida dele como era no passado. (Entrevistado 16).

[...] hoje é aquela corrida para pegar cargos superiores e para poder melhorar esse salário. Talvez sem um preparo, então o que a gente está sentindo muito é que as pessoas assim..., é que elas vão pedindo cargos sem saber até o quê que vão fazer, depois quando chegam lá, é que elas vão estar tentando desenvolver aquelas certas atividades, eu estou achando que está tendo até uma certa imaturidade... (Entrevistado 23).

[...] você tem também um nivel de exigência por parte do cliente muito grande. Então, as pessoas são mais esclarecidas, as pessoas têm mais opções. Muitas vezes você se depara mesmo com situações aonde tem que, não só atender bem, mas procurar solução legal para o cliente. (Entrevistado 37).

Como visão positiva, a profissão é descrita com maior dinamismo, a valorização dos funcionários e dos clientes, o surgimento de ferramentas de gestão que facilitam o trabalho. $\mathrm{O}$ bancário deixou de ser acomodado.

A profissão do bancário no passado, era um balconista qualificado e, muitas vezes, não tinha qualificação, era mais um serviço, mais um serviço. Hoje nós saímos da linha de serviço e passamos... continuamos a prestar serviço, mas a oferecer produtos. Produtos 
que proporcionem evolução patrimonial aos nossos clientes, produtos que proporcionem comodidade, tranqüilidade aos nossos clientes. Então o mercado como um todo mudou muito, e para nós bancários houve uma exigência de evolução junto a esse mercado. (Entrevistado 05).

No (nome do banco) a maneira deles trabalharem, o valor que eles dão hoje nas pessoas hoje, nos funcionários, nos clientes, no meio ambiente... mudou muito o banco para cá. Lá de trás para hoje, nossa, muito. (Entrevistado 11).

A profissão no passado é basicamente a mesma, o quê que você tem, hoje, de diferente, você tem ferramentas novas de gestão. São ferramentas novas de gestão de riscos, a lista de marketing para você trabalhar, as ferramentas e diversificar, a informática vem mudando demais. (Entrevistado 21).

Eu acho que isso mudou muito com o tempo. O banco, as pessoas tendem a evoluir, tem que se evoluir, porque quem não evolui é descartado. Eu acho que antigamente vestia assim um prestígio de uma certa acomodação. Hoje em dia você não pode ter isso. (Entrevistado 39).

A maioria dos entrevistados (35 respondentes) expressou uma visão negativa do futuro da profissão. Apenas 15 descreveram o futuro de uma forma positiva. A Tabela 23 expõe tais informações.

Tabela 23 - Distribuição dos respondentes da pesquisa por resposta à pergunta "Como você vê a profissão de bancário no futuro?"- dados coletados nas agências bancárias de julho a outubro de 2007

\begin{tabular}{l|c|c}
\hline Categorias & Quantidade & Freqüência \\
\hline Possuem uma visão positiva & 15 & $30 \%$ \\
Possuem uma visão negativa & 35 & $70 \%$ \\
\hline Total & $\mathbf{5 0}$ & $\mathbf{1 0 0} \%$ \\
\hline \hline
\end{tabular}

Fonte: Dados de pesquisa

As visões positivas do futuro são associadas à constante qualificação do bancário enquanto profissional ou tornar-se uma atividade mais valorizada e, em alguns casos, como um consultor financeiro. Outros vêem a profissão de forma positiva como uma sobrevivente, ainda necessária no futuro.

O bancário sempre vai existir, acho que num..., muitas ferramentas hoje substituem o trabalho manual que você fazia, pesquisas aquela coisa muito exaustiva. Mas sempre vai ter que ter alguém que vai deferir um limite de contas, que ainda vai demonstrar para você tudo que o cliente pode ter, como base e os dados cadastrais dele. Mas tem sempre alguém que vai ter que decidir o quê que pode dar ou não para determinado cliente. (Entrevistado 21).

Ah, eu acho que a profissão do bancário até tende a ser mais cada vez mais importante, em função das mudanças que estão ocorrendo ai na sociedade, no próprio sistema financeiro. (Entrevistado 40).

Para os respondentes, o futuro pode ser visto de forma negativa, porque haverá redução do 
número de funcionários, as agências serão reduzidas e automatizadas e haverá aumento da competitividade entre os bancos.

O futuro é que diminua mais ainda, a quantidade de empregados nas agências, que a informatização substitua, sabe, as pessoas. Então quem quer se garantir, tem que procurar crescer dentro da empresa, é procurar alguma função, sempre subir um degrau onde a gente está. (Entrevistado 44).

Então, acho que para o futuro, com a tecnologia, o avanço, o contato do cliente realmente vai ser mais como o universo da sala de auto-atendimento, universo virtual. $O$ que tem de interno no banco, eu acho que esse, com o tempo, vai diminuir bastante, não vai ser tão necessário, tantos funcionários para executar as funções que hoje tem. Acredito que a evolução aí, o progresso, a tecnologia, vai restringir isso, o banco vai ser mais virtual. (Entrevistado 43).

Os dados coletados mostraram que os bancários se dividem no que diz respeito ao passado e ao presente, quando são questionados sobre as principais transformações. A tecnologia e a redução do número de funcionários nos bancos foram os elementos mais citados. Conseqüentemente, relatam uma perda de status da profissão e uma redução dos benefícios financeiros, assim como temem pela falta de estabilidade na profisssão. O futuro é visto de forma negativa pela maioria, no temor de que as agências reduzam ainda mais, principalmente nas funções operacionais. Pouco foi dito sobre mudanças gerenciais, mas estas podem ser percebidas indiretamente por meio da forma como lidam com os clientes, na forma que os resultados são cobrados, nas políticas de recursos humanos que foram comentadas de forma indireta.

\subsection{VALOR DO TRABALHO}

Dentro da categoria de análise "Valor do Trabalho", procurou-se compreender, ao longo da fala dos entrevistados, que tipo de importância é dada ao trabalho, na tentativa de entender o que significa esta atividade em suas vidas. Foram consideradas as falas sobre o trabalho em si, sobre a categoria profissional e sobre a organização, desde que associadas à categoria de análise. Ao analisar os discursos dos entrevistados, pôde-se observar quatro valores principais: "Valor Pessoal", "Valor Econômico", "Valor Social" e "Valor Moral". Em alguns casos tais valores eram descritos de forma positiva, ou seja, como coisas essencialmente benéficas e, em outros casos, de forma negativa, ou seja, como maléficas. Deve ficar claro que as separações entre os valores às vezes não são tão nítidas, mesmo porque, em alguns casos estão diretamente associados. Ou seja, o "Valor Moral" reforça o "Valor Pessoal", assim como o "Valor Econômico" reforça o "Valor Social" e assim por diante. 


\subsubsection{Valor Pessoal}

Entre os entrevistados, 48 citaram algum tipo de "Valor Pessoal" associado ao trabalho e dois não associaram a atividade a tais valores. A grande maioria, 32 entrevistados, cita o trabalho como valor positivo, sendo que outros 15 entrevistados associam "Valores Pessoais" positivos e negativos. Apenas um entrevistado citou o trabalho como "Valor Pessoal" exclusivamente negativo (Vide Tabela 24).

Tabela 24 - Distribuição dos respondentes da pesquisa por categorização do trabalho como Valor Pessoal em seus discursos - dados coletados nas agências bancárias de julho a outubro de 2007

\begin{tabular}{|c|c|c|}
\hline Categorias & Quantidade & Freqüência \\
\hline O trabalho é descrito com valor pessoal - positivo & 32 & $64 \%$ \\
\hline O trabalho é descrito com valor pessoal - negativo e positivo & 15 & $30 \%$ \\
\hline O trabalho é descrito com valor pessoal - negativo & 01 & $02 \%$ \\
\hline Não citaram valores pessoais & 02 & $04 \%$ \\
\hline Total & 50 & $100 \%$ \\
\hline
\end{tabular}

Fonte: Dados de pesquisa

Em termos de "Valor Pessoal" positivo, o trabalho é descrito de formas extremamente diversas. Dentre as mais citadas, o trabalho é associado a um prazer, uma satisfação pessoal, uma realização pessoal e profissional, uma forma de obter uma auto-estima, algo para ocupar o dia e a mente.

[...]o trabalho para mim é uma realização. Eu abrir os olhos cedo, agradecer por mais um dia, ter saúde, e ter alguma coisa para preencher o meu dia, e essa coisa é prazerosa, e a cada dia que passa, você procura ser melhor do que ontem. (Entrevistado 16).

Acho que o trabalho traz tudo para gente. Tanto uma realização profissional, que a nossa organização hoje nos concede isso, traz beneficios financeiros, que para isso a gente tem condições de estar fazendo as coisas tanto pessoais para gente, como para família. Então, acho que a importância é total, fora o prazer que a gente tem de estar fazendo o trabalho. (Entrevistado 26).

Trabalho é uma realização do ser humano como pessoa, como missão de vida. Deus nos coloca na vida com as competências, com as fragilidades também, lógico. Mas, o trabalho é uma forma de se realizar, o ser humano como pessoa, como ser membro da comunidade e o trabalho é muito bom, eu adoro trabalhar, penso que o trabalho me realiza muito. (Entrevistado 27 ).

O trabalho também é descrito como uma forma de crescimento pessoal, de aprendizagem de construção cotidiana da própria pessoa.

A gente precisa do nosso trabalho para sobreviver, o trabalho faz a gente se sentir completo, dia após dia [...] faz a gente crescer como pessoa. Aquela responsabilidade de estar ali a serviço, ele te gera internamente uma sensação de responsabilidade, 
entendeu? Essa responsabilidade que te move, ela que te faz levantar todo dia. Não é como responsabilidade do ponto negativo não, é a responsabilidade de você ser importante naquilo que você faz, da tua presença ali ser importante. (Entrevistado 15).

O trabalho é uma coisa importante na vida da gente não pelo salário só, mas por estar em contato com os colegas de trabalho, a gente vai aprendendo algo novo todo dia. No meu caso que trabalho com o banco, com os clientes também, porque todo dia chegam clientes com alguma novidade, com algum, algum ensinamento novo, entendeu? Então acho que todo mundo, assim como eu, procura o trabalho, porque o trabalho é uma vitamina para gente poder sobreviver. (Entrevistado 20).

O trabalho, para mim, é tudo, porque sem ele não sou ninguém. E eu te falo mais, eu já estou preocupada, porque eu já estou aposentando e o quê que eu vou fazer daqui pra frente? Eu não sei fazer outra coisa. (Entrevistado 24).

O trabalho para mim é tudo. O trabalho é estabilidade, é equilibrio emocional, é sustento, é ideal. O trabalho para mim, são essas coisas, eu já tenho um bom tempo de trabalho. Eu estava lembrando, outro dia eu sai mais cedo, eu brinquei com o gerente lá, $o$ (nome do colega de trabalho) "Eu tenho vergonha de sair porque o sol está alto" (risos), mas por quê? Eu passei a minha vida trabalhando doze, treze horas por dia, então trabalhar seis horas para mim é uma coisa muito sabe, muito rápida. Ela passa para mim numa fração de segundos, agora ficar sem trabalhar? Coisa terrivel, coisa que incomoda qualquer pessoa, o homem precisa do trabalho igual ele precisa do alimento para ele, ele tem que ter aquela atividade, o trabalho para mim é fundamental. (Entrevistado, 34).

O trabalho também é uma forma de realizar seus sonhos pessoais e familiares. É uma forma de ter bens e projetos de vida e de qualidade de vida. É uma forma de valorizar os seus consumos e legitimá-los.

E também o trabalho não só representa uma realização pessoal sua. Além de você se sustentar com o salário, você também tem um projeto, em cima do trabalho, você faz ali um projeto de vida. (Entrevistado 40).

[...] aquilo que te eu falei, o trabalho enobrece, ocupa a mente. Mas eu acho assim, muita gente não tem respeito até pelos outros. Aliás, gente da minha idade, tenho vinte e seis anos, mas gente assim, um pouco mais nova, tem vinte e três vinte e dois anos, não sabe o que é respeitar uma pessoa. Não sabe o que é dar valor no dinheiro, dar valor num carro, dar valor até em outra pessoa, porque não trabalha. Você está ali trabalhando, você acordou cedo, você suou ali, mesmo uma pessoa que trabalha com o próprio pai. Você trabalha com seu pai, mas você está ali acordando cedo e indo até seis horas da tarde. Você sabe que esse trabalho está te dando dinheiro. O que você for comprar, você vai comprar com muito mais gosto do que se chegar uma pessoa aí, que está estudando, vinte e três anos, fala assim: "Oh pai, dá dinheiro para comprar aquele tênis?" Vai comprar, vai pôr aquele tênis no pé e vai achar bonito. Agora uma pessoa que trabalhou, juntou o dinheiro, para pôr aquele tênis no pé, ela vai sentir o gosto de ficar usando aquele tênis, eu acho que é isso: o trabalho deixa a pessoa mais feliz em ter, em poder ter alguma coisa. (Entrevistado 02).

Ressalta-se na fala deste último algo que ficou evidente em diversas falas de outros entrevistados. Ao se referenciar a outros consumidores, principalmente clientes, há sempre o 
sentido de descrevê-los como pessoas que, muitas vezes, não sabem o valor do dinheiro. Valor este que está associado ao valor trabalho. A convivência com pessoas que se endividam, que buscam financiamentos e que se encontram em dificuldades provenientes de consumo, cria uma certa consciência em relação ao uso mais racionalizado do dinheiro. Tal questão foi debatida durante o focus group e os bancários que participaram confirmaram o fato de que são mais "controlados" no uso do dinheiro e, conseqüentemente, na forma como consomem. Procuram sempre consumir dentro dos "limites".

Como valor pessoal negativo, o trabalho é delineado como fonte de frustrações, estresse, decepções, dentre outros sentimentos provenientes da sua relação com a execução do trabalho, com os colegas ou com a organização.

[...] eu me sinto desgostoso por causa das frustrações que aconteceram durante o processo de evolução dentro da empresa. Eu não me sinto muito feliz hoje não. Melhorou muito, mas eu não me sinto feliz não. Eu acho que eu tenho que buscar outras oportunidades, eu acho que eu tenho um potencial maior do que eu aplico aqui. Eu uso um terço da minha capacidade de aplicação de estratégias dentro da empresa hoje, e isso me deixa irritado, isso me deixa profundamente irritado, porque eu não consigo aplicar o meu lado empreendedor de ver as coisas, o meu lado criativo de fazer movimentar a máquina. (Entrevistado 05).

[...] quando eu perco um negócio eu me sinto frustrado, às vezes, sinto bem por ser bem avaliado, tem dia que estou meio devagar. (Entrevistado 10).

[...] o bancário normalmente é aquela pessoa preocupada com detalhes também. Alguns se tornam neuróticos. Fazer tudo certinho, tudo arrumadinho, também tem isso, porque a profissão induz a isso. (Entrevistado 14).

[...] que cambada de gente mediocre (sobre os bancários), de verdade, assim, porque bancário, qualquer um pode ser, porque a pessoa que fica estagnada só naquilo, então ela se deixa levar pela mediocridade. Me desculpe, mas eu sinto isso. Quando eu chego de manhã, muitas vezes, no banco eu falo assim: Nossa o bancário qualquer um pode ser, né? É só um pouquinho de treino. E as pessoas, eu vejo gente lá dentro que não seria outra coisa na vida se não fosse bancário. Isso até me dá um pouco de angústia, eu falo assim: Nossa, fulano, se não fosse o banco, heim? Qual que ia ser da vida dessa pessoa? (Entrevistado 15).

O trabalho é percebido como um "Valor Pessoal" que freqüentemente se apresenta no discurso dos entrevistados. Embora possa ser estressante e frustrante, o trabalho também é fonte de orgulho e valorização, de concretização de projetos pessoais e profissionais, de poder realizar projetos de vida e legitimar o consumo.

\subsubsection{Valor Econômico}

O trabalho é associado a "Valores Econômicos" por 40 entrevistados, sendo que os outros 10 
entrevistados, em momento nenhum de suas falas, associaram a este tipo importância. Não houve respondentes associando a "Valores Econômicos" negativos (Vide Tabela 25).

Tabela 25 - Distribuição dos respondentes da pesquisa por categorização do trabalho como Valor Econômico em seus discursos - dados coletados nas agências bancárias de julho a outubro de 2007

\begin{tabular}{l|c|c}
\hline Categorias & Quantidade & Freqüência \\
\hline O trabalho é descrito com valor econômico - positivo & 40 & $80 \%$ \\
O trabalho é descrito com valor econômico - negativo & 00 & $00 \%$ \\
Não citaram valores econômicos & 10 & $20 \%$ \\
\hline Total & $\mathbf{5 0}$ & $\mathbf{1 0 0} \%$ \\
\hline \hline
\end{tabular}

Fonte: Dados de pesquisa

Ao descrever o trabalho como "Valor Econômico", alguns se pautam em aspectos da constituição de um patrimônio para si ou para a família, uma forma de sobrevivência.

(O trabalho) Representa uma oportunidade muito boa de eu possuir meu pé-de-meia e buscar fazer realmente o que eu quero. (Entrevistado 05).

Outra vez, primeira coisa: subsistência, (risos). Basicamente, eu acho que quem falar diferente não está... Eu acho que o trabalho é a primeira coisa hoje na sociedade. Hoje seria subsistência e depois eu acho que a pessoa tem que arrumar um trabalho que ela goste de fazer. (Entrevistado 10).

Então não sei, para mim trabalho, ele é tudo porque através dele que eu tiro o sustento da minha família. (Entrevistado 15).

Outros associam à possibilidade realizar seus desejos de consumo.

A gente brinca, mas quando você está trabalhando é uma coisa gostosa, sua auto-estima está lá em cima, você pode fazer as coisas que você quer, você pode estar comprando ou você pode estar guardando, isso é bacana. (Entrevistado 07).

O meu trabalho é muito importante, necessário pelo dinheiro, pela realização de consumo mesmo, e também para ocupar a cabeça. É bom porque a gente estuda, estuda, e uma hora a gente quer colocar em prática o que a gente estuda. Acho que o trabalho é importante pra isso. (Entrevistado 17).

[...] me dá prazer de trabalhar e me dá condições de ter bens materiais [...] (Entrevistado $32)$.

O trabalho também foi associado à liberdade e à estabilidade financeira.

(O trabalho) representa uma satisfação pessoal, representa alguns é... alguma liberdade financeira, representa realização junto aos meus filhos. (Entrevistado 33).

[...] todas as realizações que eu tenho na minha vida. Eu sempre trabalhei, desde os 15 anos. Foi meu primeiro emprego, e meu primeiro emprego eu já juntei dinheirinho para comprar meu primeiro aparelho de som, entendeu? Porque meu pai sempre explicou para gente, não dependa de homem... vocês podem casar, mas não dependam de dinheiro de homem, trabalhem para ter suas coisas entendeu? Então, desde 15 anos, eu pagava 
meu dentista, se eu precisava ir ao médico eu pagava, eu pagava meu remédio. Eu cresci com essa mentalidade de que eu trabalho para ter as minhas coisas, entendeu? (Entrevistado 46).

Os entrevistados que não associaram "Valores Econômicos" ao trabalho, recorreram principalmente a "Valores Pessoais" positivos e a "Valores Morais" positivos. O trabalho é entendido, como algo essencial para a sobrevivência e inserção econômica na sociedade. É uma forma de não depender de outros para sua subsistência. É o caminho para realizar os desejos materiais e patrimoniais.

\subsubsection{Valor Social}

Poucos entrevistados associaram valores sociais ao trabalho, sendo que a maioria (39 bancários) não fez qualquer menção. Sete respondentes descreveram como um "Valor Social" positivo e quatro como "Valor Social" negativo (Vide Tabela 26).

Tabela 26 - Distribuição dos respondentes da pesquisa por categorização do trabalho como Valor Social em seus discursos - dados coletados nas agências bancárias de julho a outubro de 2007

\begin{tabular}{l|c|c}
\hline Categorias & Quantidade & Freqüência \\
\hline O trabalho é descrito com valor social - positivo & 07 & $14 \%$ \\
O trabalho é descrito com valor social - negativo & 04 & $08 \%$ \\
Não citaram valores sociais & 39 & $78 \%$ \\
\hline Total & $\mathbf{5 0}$ & $\mathbf{1 0 0} \%$ \\
\hline \hline
\end{tabular}

Fonte: Dados de pesquisa

Ao descrever o trabalho como "Valor Social" positivo, alguns direcionaram para a possibilidade de cumprir uma função benéfica na sociedade. Alguns associam ao fato de serem funcionários de um banco público.

[...] eu acho que a gente, é uma fabrica de realizações. Eu não sei separar. Há dois meses atrás, eu soltei um credito mobiliário para um senhor, mas se você vê a alegria que o senhor ficou, a satisfação. Já era um senhor, um rapaz de sessenta anos e a primeira casa dele com a família. Uma coisa super bacana. (Entrevistado 07).

[...] quando eu sei o que estou fazendo ali é útil, que eu mudei a vida de alguma pessoa que sentou na minha mesa aquele dia. (Entrevistado 15).

Alguns associam ao fato de serem funcionários de um banco público e à função que a instituição tem na sociedade, distinguindo dos demais bancos privados.

[...] por ser estatal e ter um compromisso com o Estado, isso me identifica, isso me identifica um pouco, porque se eu estivesse num banco, vou falar o nome dum banco aqui que eu jamais me identificaria, num tenho nem condições, (nome de outro banco), por exemplo, (nome de outro banco) é um banco totalmente, é uma máquina de sugar pessoas 
mesmo. É uma empresa que tem se destacado aí, para os estagiários. É uma empresa que você, estando na faculdade, com certeza, já trabalha lá. Eles fazem do estagiário um funcionário, não remuneram bem, logo dispensam, não têm compromisso com ele, não têm compromisso com cliente, não têm compromisso com a sociedade, não têm compromisso com ninguém. (Entrevistado 14).

Há os bancários que descrevem como valores positivos o status da profissão e o respeito na sociedade.

[...] acho que trabalhar no banco te dá um pouco de status diferente, você é visto diferente na sociedade. (Entrevistado 07).

[...] você consegue respeitar e ser respeitado, acho que hoje em dia é tudo, o trabalho para mim, é tudo. (Entrevistado 08).

Outros afirmam que são bem vistos em termos de status pela aparência e como consumidores. Acabam tendo que manter as aparências que são esperadas pelos outros, sendo uma justificativa para consumir.

[...] a gente está incluido na classe média alta pela sociedade, mas, não realmente pelo salário que a gente ganha. A gente acaba vivendo esse lado, mas para poder manter esse status mesmo. Se eu, por exemplo, eu trabalho numa cidade pequena, eu tenho que ir de gravata, tal, trabalhar. Se, no final de semana eu começo a andar de roupa rasgada e de pé no chão, carro velho, essas coisas, o pessoal começa a olhar de outra forma, entendeu? (Entrevistado 20).

[...] tem a parte legal de ser bancário, vamos supor assim, você é bem visto, vai fazer uma compra, alguma coisa e faz muita amizade. Agora financeiramente mesmo, hoje em dia, não é aquela coisa, que a gente tinha falado, a gente tinha comentado atrás, não é aquela coisa mais, hoje, financeiramente, mas é bom. (Entrevistado 28).

Dentre os valores sociais negativos, o entrevistado descreve a perda do status em relação ao passado da profissão.

Eu acho que a gente desempenha um papel muito importante e, principalmente, carrega uma responsabilidade todos os dias. De repente a gente poderia ser um pouco mais remunerado pela função, como era antes, porque eu te falei que antigamente bancário tinha um papel na sociedade muito mais importante do que parece que tem hoje. (Entrevistado 06).

Outro ponto que se percebeu em relação ao valor negativo expresso pelos entrevistados é a perda do poder político da categoria profissional.

(A categoria profissional é) Extremamente desvalorizada, vendida, vendida. Está nas mãos dos banqueiros, sem força política nenhuma. O máximo que nós estamos conseguindo anualmente na negociação salarial é a reposição da inflação, certo? Antigamente se conseguia negociações sérias. [...] mas hoje a classe bancária se vendeu ao poder judiciário. [...] e todo mundo morre de medo de perder o emprego, porque a quantidade de beneficios que o banqueiro ofereceu para a classe dos bancários, vem 
tampar o sol com a peneira, no que diz respeito à defasagem salarial do mercado. Muitos bancários ficam inseguros e amedrontados, com medo mesmo de perder seu emprego por causa dos benefícios, não por causa do salário em si, o salário em si, não é difícil de conseguir o mesmo equivalente no mercado, o que você perde em si, quando você sai da classe bancária, são os benefícios, que são muito bons. Então hoje eu vejo uma classe que ela não tem poder politico, poder nenhum para negociação política. (Entrevistado 05).

Um entrevistado expressou o trabalho dentro de uma "Visão Social" negativa em função do impacto negativo que os bancos têm na forma de atuar na sociedade, ou seja, o banco gerando problemas sociais.

De dez pessoas que estão em bancos, nove estão porque precisam e uma está porque gosta. Digo para você isso, hoje ainda é assim, devido a esse leão (o banqueiro) que tem por trás, esse leão insaciável que desrespeita você, quer dizer, essa vontade de ganhar, de ganhar, de ganhar. Ele acaba invadindo a sua privacidade, invadindo a sua vida, invadindo o seu corpo, a sua alma para poder tomar tudo pra ele. O banqueiro, infelizmente, ele é muito poderoso nessa parte, e não faz isso só para sociedade, ele faz isso com, com o bancário também. É um ramo que ganhou muito, ganha muito dinheiro. (Entrevistado 14).

Os "Valores Sociais" se polarizaram entre ter função social (positivo) e ser prejudicial à sociedade (negativo) e o status idealizado pelos outros (positivo) e o status real enfraquecido (negativo). A perda da força política da categoria em termos de negociação e mobilização também se destaca.

\subsubsection{Valor Moral}

O trabalho foi delineado como "Valor Moral" positivo para 21 entrevistados. Não houve quem citasse "Valores Morais" negativos associados ao trabalho e 29 bancários não associaram esse tipo de valores ao trabalho (Vide Tabela 27).

Tabela 27 - Distribuição dos respondentes da pesquisa por categorização do trabalho como Valor Moral em seus discursos - dados coletados nas agências bancárias de julho a outubro de 2007

\begin{tabular}{l|c|c}
\hline Categorias & Quantidade & Freqüência \\
\hline O trabalho possui um valor moral - positivo & 21 & $42 \%$ \\
O trabalho possui um valor moral - negativo & 00 & $00 \%$ \\
Não citaram valores morais & 29 & $58 \%$ \\
\hline Total & $\mathbf{5 0}$ & $\mathbf{1 0 0} \%$ \\
\hline \hline
\end{tabular}

Fonte: Dados de pesquisa

Dentre as respostas, observou-se que o trabalho é descrito como forma de engrandecer, dignificar ou enobrecer a pessoa. 
Porque o trabalho acaba dignificando a pessoa, eu acho que... graças a Deus eu tenho um trabalho hoje. Porque eu não saberia ficar... ser dona de casa, ficar em casa, eu sou uma pessoa muito dinâmica. Hoje eu acho que o trabalho é muito importante. (Entrevistado 01).

[...] eu acho que sem o trabalho, como diz a frase, o trabalho engrandece o homem, e eu acho que realmente você se sente melhor trabalhando, buscando em tão pouco tempo o que você quer, buscando um objetivo para sua vida. (Entrevistado 13).

Trabalho dignifica, você tem aquela ocupação, ficar em casa, sem fazer nada, não tem nem como. (Entrevistado 28).

Ah, o trabalho é tudo. Ele engrandece o homem, é onde a gente consegue realizar os sonhos, consegue realizar os sonhos dos outros, dos clientes, das outras pessoas. E a gente vê que hoje o que acontece no Brasil, a maioria das pessoas que não tem um trabalho, tem baixa auto-estima, não consegue fazer parte dentro da sociedade. Fica muito aquém. Então, o trabalho tem que ser tudo, você tem que valorizar, tem que agradecer a cada dia, cada dia que eu acordo eu agradeço pelo meu trabalho, pela minha vida, então, acho que é muito importante na vida da gente.(Entrevistado 50).

Trabalho é ser ativo. Quem não trabalha é dondoca ou inútil.

[...] eu não sei ficar sem (trabalho), eu sou uma pessoa totalmente ativa, sou ativo para caramba. (Entrevistado 03).

Eu não consigo me imaginar parada, não nasci para ser dondoca. Sabe aquela coisa de ficar: ah! O que é que eu vou faze. Eu não consigo ficar parada, eu não sou workaholic, não so. Mas o trabalho é bem aquela coisa do Lutero: o trabalho dignifica o homem, eu acho que a gente é digno por fazer alguma coisa em prol de alguém, e só fazer essa uma coisa já é trabalho para mim. (Entrevistado 15).

[...] eu sinto que o trabalho é vital na vida de uma pessoa, num importa o quê, porque, se você for sobreviver, eu fico até pensando na questão da aposentadoria. Viver só de aposentaria sem atividade profissional eu acho dificil, porque o trabalho mantém as pessoas ocupadas, mantém a dinâmica [...] Então o trabalho é vital, não é só a questão mesmo de remuneração, você precisa pra você se sentir útil, bastante. (Entrevistado 30).

O trabalho é... a parte da gente se sentir útil, mais útil do que a gente pode ser normalmente, sem trabalhar, sabe? (Entrevistado 32).

Dessa forma, há uma visão de que o trabalho faz as pessoas serem melhores. O "não trabalhar" é associado a elementos moralmente negativos, e as pessoas se sentem culpadas. Como foi citado em outra fala, o funcionário trabalha seis ou oito horas por dia, dependendo do cargo, e sente culpa de não trabalhar como os demais empregados de outros setores econômicos. Trabalhar é preciso, é necessário para a construção moral do ser.

\subsection{VALOR DO CONSUMO}

De forma semelhante à categoria anterior, o "Valor do Consumo" procura ver, ao longo da 
fala dos entrevistados, quais sentidos são dados a esta variável, qual a importância para o sujeito. Para composição dessa categoria, apropriou-se da fala dos entrevistados sobre o consumo e o consumidor. Utilizou-se os mesmos valores da categoria "Valor do Trabalho" para analisar as falas, uma vez que se observou haver congruências. Também observou-se se os sentidos dados eram positivos e negativos.

\subsubsection{Valor Pessoal}

O consumo é descrito como "Valor Pessoal" positivo para 41 entrevistados. Seis funcionários o expuseram com valores negativos e outros três citaram valores positivos e negativos em termos pessoais ao mesmo tempo (Vide Tabela 28).

Tabela 28 - Distribuição dos respondentes da pesquisa por categorização do consumo como Valor Pessoal em seus discursos - dados coletados nas agências bancárias de julho a outubro de 2007

\begin{tabular}{|c|c|c|}
\hline Categorias & Quantidade & Freqüência \\
\hline O consumo é descrito com valor pessoal - positivo & 41 & $82 \%$ \\
\hline O consumo é descrito com valor pessoal - negativo e positivo & 03 & $06 \%$ \\
\hline O consumo é descrito com valor pessoal - negativo & 06 & $12 \%$ \\
\hline Não citaram valores pessoais & 00 & $00 \%$ \\
\hline Total & 50 & $100 \%$ \\
\hline
\end{tabular}

Fonte: Dados de pesquisa

Como "Valor Pessoal" o consumo é associado ao prazer, à satisfação, aos desejos.

Quando eu compro esse tipo de coisa, eu sinto muito prazer, muita satisfação. (Entrevistado 05).

[...] eu tenho prazer em comprar, eu gosto. Já minha esposa dá uma controlada. Ela diz ainda bem que eu não tenho paixão por carro, porque se eu tivesse...estava enrolado. Eu gosto de comprar, mas coisa para casa, sabe, estar mudando, tem um móvel ali de seis meses, pelo amor de Deus vamos trocar ele, vamos fazer alguma coisa, o quê mais compro é isso mesmo. Às vezes, assim pelo telefone sempre tem alguma coisinha nova. (Entrevistado 07).

Eu sinto um prazer de estar fazendo aquela "compração", e fazer uma boa compra, existe um prazer nessa busca e nesse atender a necessidade. (Entrevistado 34).

Então, o consumo é aquilo que eu te falei, uma certa satisfação, ao mesmo tempo culpa, é como se eu não consumisse... eu me sentiria infeliz. É isso, é felicidade, é momentos de felicidade.(Entrevistado 41).

É satisfazer uma necessidade quase que fisiológica.

[...] eu sinto que eu estou satisfazendo uma necessidade minha, eu sinto prazer em comprar, certo, é uma coisa que... aquela força mesmo que a mídia faz, que é propaganda e tudo. E a gente acaba envolvendo, tanto que vejo uma TV, dessas de trinta 
e tantas polegadas, TV de plasma, então acho legal. Meu próximo passo vai ser comprar uma televisão decente, só que eu vou esperar abaixar o preço. Não vou comprar uma de doze mil, (risos) já está em três novecentos noventa, então estou esperando chegar um pouquinho mais... (Entrevistado 12).

[...] eu tenho assim uma tara por produtos eletro-eletrônicos, notebook, computador, som, isso dai. [...] num sei uma sensação de realização. (Entrevistado 22).

O consumo é descrito como uma forma de compensação pessoal pelo desgaste provocado pelo trabalho ou pelo trabalho bem feito.

[...] uma sensação boa, poder comprar, de ver o quê que o dinheiro está trazendo de bom para gente. É um resultado do trabalho, quem trabalha muito, pode gastar o dinheiro que ganha.[...] Eu já percebi que em momentos que a gente está mais fragilizada, é o momento que a gente quer comprar, parece que para provar alguma coisa. Eu, eu tenho muitas fases assim, às vezes eu fico um mês sem comprar nada, porque eu não quero, porque eu não preciso, e, de repente, eu estou num lugar e resolvo comprar um monte de coisas, que, na verdade, eu também não preciso. Falar que é por necessidade na verdade não é, o que a gente tem dá para gente trabalhar, roupa, sapato, mas tem horas que parece que é por prazer mesmo, de vez em quando acontece. (Entrevistado 06).

[...] eu procuro sempre comprar muito o que eu preciso. Noventa por cento o que eu preciso, e dez por cento a gente extrapola. Ah, mas não precisava ter um negócio assim, mas é um prazer que eu me dou por trabalhar muito. Eu faço muito bem feito o que eu faço, então acho que eu mereço ser ter um negócio legal. (Entrevistado 12).

Gosto (de comprar), me satisfaz bem, comprando, me tira da depressão. (Entrevistado 24).

O consumo seria a contrapartida do trabalho. De um lado eu trabalho, eu transpiro, eu busco realizar pessoas, realizar oportunidades como fornecedor e outro lado eu também curto aquele... é um complemento do trabalho. (Entrevistado 27).

Em termos negativos, alguns descrevem como um vício que é incontrolável e, às vezes, perigoso. Outras vezes é descrito como uma angústia.

O consumo para mim? Para mim é um negócio até meio complicado, porque eu acho que eu sou altamente consumista. Assim, no que gosto é até perigoso isso, o consumo, por exemplo, sei, eu tenho vinte sapatos, para quê? Porque eu vou querer vinte e um, dois. Eu vou lá e compro, vinte e um. Bijuteria, eu tenho um milhão de bijuterias, para quê? Eu vou lá, então... Assim, ultimamente até eu tenho trabalhado a minha cabeça. Antes eu comprava, às vezes para agradar uma pessoa, ou, às vezes mesmo para ter aquilo ali, hoje, eu já estou pensando duas vezes. Eu já estou conseguindo falar não, não eu já tenho, para quê que eu vou querer mais um? Eu, para mim é complicado, porque eu sou consumista. (Entrevistado 24).

O consumo, às vezes, representa para mim uma angústia, porque a gente vive num mundo que é muito consumista. E ai é uma grande questão que eu trago para mim é se eu estou consumindo aquilo que é necessário para minha vida, para minha família ou para as outras pessoas. (Entrevistado 31).

[...] eu acho o consumo um perigo, porque a pessoa pode ficar doente por causa das 
coisas. (Entrevistado 42).

Mas é algo que precisa ser controlado e dominado para não tomar conta do indivíduo. E esse controle advém da experiência em ver as pessoas se endividando excessivamente. O contato com o cliente cria esta consciência a respeito do consumo.

Então, hoje, para mudar um pouco minha vida, eu coloquei algumas perguntas, primeiro "eu preciso?" Se eu falar que eu preciso eu passo para outra pergunta "eu posso?" Se eu barrar nessa "eu posso?" ai eu tenho que voltar no "eu preciso", mas gente, vale a pena fazer um financiamento? Vale a pena eu me endividar por isso? Não, então, eu não compro. Então, eu acho que as pessoas, a maioria hoje, pensam assim, não, eu quero, mas não sabem se precisam. [...] Mas acho que eu estou tentando mudar um pouco, dá para mudar, dá. Se eu quero realmente, não vou ficar sofrendo por isso não. (Entrevistado 08).

É uma coisa muito séria, você tem que saber levar, senão, você acaba extrapolando. Eu sou uma pessoa extremamente controlada e eu consigo levar essa parte do consumo numa boa. (Entrevistado 01).

Consumo é fuga, na maioria das vezes, no meu caso, foi fuga e eu tento me controlar hoje em dia. Mas ele é necessário. Bem dosado, bem trabalhado. A gente não pode sair comprando tudo que vem pela frente. Até porque depois vem o vazio de pensar (Entrevistado 15).

$\dot{E}$, não sou consumista, tenho muito controle financeiro (risos) e só consumo em extrema necessidade, mesmo gostando de consumir, só em extrema necessidade.(Entrevistado 49).

O consumo é entendido como bom desde que seja dosado e controlado. É uma linha tênue que você deve seguir entre o prazer e o vício, entre a satisfação e as conseqüências financeiras.

\subsubsection{Valor Econômico}

Dos 50 bancários entrevistados, 41 associaram o consumo a "Valores Econômicos" positivos e apenas nove não associaram a variável a este valor. A Tabela 29 detalha estas informações.

Tabela 29 - Distribuição dos respondentes da pesquisa por categorização do consumo como Valor Econômico em seus discursos - dados coletados nas agências bancárias de julho a outubro de 2007

\begin{tabular}{|c|c|c|}
\hline Categorias & Quantidade & Freqüência \\
\hline O consumo é descrito com valor econômico - positivo & 41 & $82 \%$ \\
\hline O consumo é descrito com valor econômico - negativo & 00 & $00 \%$ \\
\hline Não citaram valores econômicos & 09 & $18 \%$ \\
\hline Total & 50 & $100 \%$ \\
\hline
\end{tabular}

Fonte: Dados de pesquisa

Enquanto "Valor Econômico", o consumo, em geral, sai da associação direta com o entrevistado e passa a ser visto como algo macro-social. Ou seja, o consumo e o consumidor 
não são descritos economicamente como uma variável atrelada a ele, sujeito, mas ao contexto em que está. Neste sentido, o consumo e o consumidor são expressos como as variáveis que fazem com que a economia se mova, algo essencial para que as coisas existam, tais como emprego, empresas, trabalhadores, salário. Acaba sendo descrito como algo que determina a existência dele como trabalhador. E isso é descrito tanto na ação de consumir, quanto na pessoa do consumidor.

[...] se não tiver consumo não existe nada. (Entrevistado 17).

Eu acho que é a base do capitalismo. Se não tiver o consumidor ali, não vai ter, vamos supor, não vai precisar de um banco para emprestar o dinheiro, não vai ter que dar um cheque, pagar um cartão de crédito, não vai precisar é... pode fazer camiseta branca e calça azul para todo mundo que vai ser que nem Cuba, vai ser tudo igual. (Entrevistado 02).

O consumidor é quem movimenta o mercado. O consumidor é quem determina as regras, é o cliente, é o consumidor, ele determina as regras. Ele tem as limitações dele, ele tem que seguir algumas regras, porque não é o fato dele determinar o mercado, que ele faz o que bem entender, existem regras de bom censo a serem seguidas. (Entrevistado 04).

O consumidor é tudo que a empresa precisa. E é um barco em que se sabe que existem pessoas de tudo quanto é tipo. Aquele que compra para aliviar estresse, para esbanjar, para ostentar, quem é compulsivo, então, sem o consumidor não há o comércio. Não há empresas para vender produtos ou implantar seu serviços, o consumir é essencial para a vida econômica do país, até porque cria o dinamismo do país. (Entrevistado 30).

O consumidor é o caminho para atingir o sucesso econômico e conseguir os objetivos da vida.

Na minha vida, na minha profissão, representa o meu ganha-pão, entendeu, na minha profissão, eu tento atender bem os meus clientes, os meus consumidores, porque se eles não consumirem o meu produto, eu não vou conseguir atingir o meu objetivo e daí por diante, que eu não vou conseguir atingir o objetivo do banco e, por fim, eu posso correr o risco de perder meu emprego e posso não conseguir atingir o meu objetivo de vida. (Entrevistado 20).

Em alguns casos, o consumidor é descrito quase que como um produto, uma matéria-prima de "Valor Econômico" para o bancário.

Uma carteira de clientes hoje, ela vale muito mais do que qualquer outra lista de prospecção de clientes. (Entrevistado 05).

[...] eu gosto de comprar tudo, acho que sou melhor assim, o melhor que uma loja pode ter, meu namorado fala isso, eu adoro comprar... (Entrevistado 18).

O cliente, ele é, como costumo dizer, é o maior patrimônio que tem no banco.(Entrevistado 22).

Esclarece-se que, por trás do que possa parecer extremamente óbvio nas falas dos 
entrevistados, da fala sobre a importância do consumo e do consumidor, deve-se entender que há um processo de assimilação de valores muito evidente sobre uma sociedade em que o consumo se torna o grande elemento central, que faz girar tudo e todos.

\subsubsection{Valor Social}

Dez entrevistados valeram-se de "Valores Sociais" positivos e apenas um descreveu como "Valor Social" negativo ao falar sobre o consumo. Os demais entrevistados não citaram "Valores Sociais" atrelados ao consumo (Vide Tabela 30).

Tabela 30 - Distribuição dos respondentes da pesquisa por categorização do consumo como Valor Social em seus discursos - dados coletados nas agências bancárias de julho a outubro de 2007

\begin{tabular}{|c|c|c|}
\hline Categorias & Quantidade & Freqüência \\
\hline O consumo é descrito com valor social - positivo & 10 & $20 \%$ \\
\hline O consumo é descrito com valor social - negativo & 01 & $02 \%$ \\
\hline Não citaram valores sociais & 39 & $78 \%$ \\
\hline Total & 50 & $100 \%$ \\
\hline
\end{tabular}

Fonte: Dados de pesquisa

O consumidor é descrito como possuidor de um poder de determinar regras, um ser que possui direitos. Trata-se de um poder social, um poder político.

(Ser consumidor é) eu exigir meus direitos [...] eu tenho as minhas obrigações como consumidor, mas eu tenho os meus direitos como consumidor. Então eu vejo o consumidor... ser consumidor não é só comprar, ser consumidor é você comprar, é ditar as regras do mercado, as leis. E o consumidor, ele é quem movimenta o mercado. $O$ consumidor é quem determina as regras, é o cliente, é o consumidor, ele determina as regras. (Entrevistado 04).

É procurar uma coisa que te faz falta, exercendo teu direito de ser bem atendido, sabendo seu dever de atender com cortesia. (Entrevistado 15).

O consumo também é associado a um processo de transformação cultural, associado à conscientização do indivíduo.

[...] a questão da cultura do consumidor, que está cada vez mais exigente, mas isso é fruto de um processo muito maior, que é a conscientização. E também de mecanismos de defesa do consumidor, vem mudando a cultura de se ganhar dinheiro no financeiro. (Entrevistado 47).

O consumidor é alguém que tem uma necessidade, alguém que precisa ser ajudado. Ao atender suas necessidades, está-se cumprindo uma função social.

Ele várias vezes, vários momentos, o bancário é quase um psicólogo do cliente, é um 
confessionário que o cliente chega, às vezes humildemente, semi-desnudado, vamos dizer assim, a ponto de abrir o coração e "Estou precisando de dinheiro, estou numa situação e tal." Esse trabalho que eu acho muito digno e tem que ter muita serenidade para fazêlo, para atender a demanda da pessoa chegar, que é mais a cultura, os mais antigos, tomar dinheiro emprestado era uma coisa assim, ruim à moda antiga. (Entrevistado 27).

[...] esse relacionamento nosso com o cliente, você acaba sabendo, você acaba sendo um psicólogo do cliente. Você acaba sabendo, então de muitas coisas do cliente, o cliente desabafa com você[...] (Entrevistado 03).

A única associação negativa em termos sociais foi feita em relação aos impactos do consumo sobre o futuro do planeta.

Consumidor ele é chave para qualquer economia. E ele é chave também para sustentabilidade do planeta se você for pensar por aí, para ver hoje, o consumidor, se ele não tem consciência do que ele consome, ele vai estar, cada vez mais, consumindo coisas que vão impactar relações futuras. Porque hoje a gente percebe que a maioria das empresas ainda não se preocupa com a sustentabilidade. (Entrevistado 31).

As associações com valores sociais foram muito tênues, mesmo ao longo do discurso dos entrevistados como um todo.

\subsubsection{Valor Moral}

Apenas três funcionários citaram "Valores Morais" positivos associados ao consumo. Outros 13 entrevistados citaram "Valores Morais" negativos. Os demais 34 entrevistados não citaram "Valores Morais". A Tabela 31 detalha tais informações.

Tabela 31 - Distribuição dos respondentes da pesquisa por categorização do consumo como Valor Moral em seus discursos - dados coletados nas agências bancárias de julho a outubro de 2007

\begin{tabular}{l|c|c}
\hline Categorias & Quantidade & Freqüência \\
\hline O consumo possui um valor moral - positivo & 03 & $06 \%$ \\
O consumo possui um valor moral - negativo & 13 & $26 \%$ \\
Não citaram valores morais & 34 & $68 \%$ \\
\hline Total & $\mathbf{5 0}$ & $\mathbf{1 0 0} \%$ \\
\hline \hline
\end{tabular}

Fonte: Dados de pesquisa

O consumo é visto moralmente como elemento negativo, associado a um processo de culpa.

Até você prometer que isso é sigiloso, eh... no meu processo depressivo, eu adquiri compulsão por compras. [...] Primeiro eu sinto..., alegria, parece que dá aquele entusiasmo, depois dá um sentimento de culpa terrivel.(Entrevistado 15).

O consumo é supérfluo, é comprar em excesso, o que não tem necessidade, e isso é visto como moralmente errado. 
Eu acho que está meio conturbado hoje em dia. Acho que as pessoas são muito consumistas... ela quer consumir, consumir... e não pára. E eu acho assim... tem que consumir o que você precisa. [...]Então hoje o mundo está muito consumista. Para onde vai? E o resultando está aí. $O$ que está acontecendo, cada dia, as pessoas mais estressadas, cada dia trabalhando mais e não sabe para quê, consumindo não sabe o quê e sorte daqueles que se desprendem um pouco desse consumismo, acho que o grande estresse da população é o consumismo totalmente errado. (Entrevistado 08).

[...] de uma foram geral significa alguma coisa supérflua. A gente vê o primeiro passo do consumidor é estar consumindo o que não tem necessidade. (Entrevistado 20).

[...] se você for ver a moda antiga, ainda você tinha um vestido no fim de semana, você tinha um sapato e aquilo estava bom. Agora, o ser consumidor hoje é comprar em excesso. Até um filho seu mesmo, às vezes, seu filho fala assim, "mãe eu quero um celular", ai você fala assim, "meu filho você não tem necessidade disso", ai ele fala assim, "mas todos os colegas meus têm". (Entrevistado 23).

Chega, às vezes, ser descrito de forma pecaminosa, mas interessantemente, como valor positivo.

Ser consumidor é bom. É falar uma necessidade, às vezes, é... sem precisar [...] uma realização pessoal, ego, vaidade, orgulho ou para, até, atender as coisas básicas da vida [...] conforto, entra a luxúria, vai ostentação [...] (Entrevistado 30).

O consumo é um antagonismo de valores.

Um mal necessário, o consumo é o lubrificante para engrenagem que está rodando aqui. Esse consumo produz mais consumo. É um mal necessário. (Entrevistado 38).

O consumo, ele é um bem necessário. Sem ele a gente também não tem como sobreviver, mas a gente nota que o consumo exagerado para algumas pessoas acaba trazendo transtornos para ele no futuro. (Entrevistado 26).

Ao pronunciar que o consumo é "um bem necessário" o entrevistado, inconscientemente, expressou duas faces do consumo em sua fala. É um produto necessário que o indivíduo precisa possuir e é um bem que faz para si, para seu ego.

O consumo demonstra ser não só a garantia de subsistência/sobrevivência, mas de prazer, de liberdade, de plenitude dos direitos, de se sentir completo. O consumo é entendido ainda como algo que precisa ser controlado ou curado, uma doença para alguns uma droga viciante para outros. É um bom pecado.

\subsection{SER TRABALHADOR}

A análise dos discursos dos bancários permitiu identificar 29 definições do que é "Ser Trabalhador" em suas concepções. Foram consideradas todas as definições citadas por mais 
de um bancário. A Tabela 32 exibe a quantidade de bancários que citou cada uma das definições. É importante compreender que cada definição pode ter sua antítese, ou frase negativa, como igualmente definidora da categoria analisada. Por exemplo, o $2^{\circ}$ item da Tabela 32 se vale da assertiva "Ser parceiro ou companheiro dos colegas bancários" que pode ser expressa por alguns bancários como "não ser parceiro ou companheiro". O que foi considerado é que se o entrevistado vê os outros bancários como "não ser parceiros ou companheiros", mas expressa de forma recriminatória, negando o jeito como se comportam seus colegas, sendo, portanto, interpretado como negação da negação, ou simplesmente, afirmação. Isso porque o próprio respondente se vê como parceiro ou companheiro em contraposição aos demais.

O importante para esta pesquisa é que nas definições do "Ser Trabalhador" aparecem diversas citações de consumo e consumidor como referência para que o respondente descreva esta categoria. O "cliente/consumidor" ( $1^{\mathrm{o}}$ item da Tabela 32) apareceu explicitamente na definição de 30 entrevistados, associado a diversas possíveis ações, sendo que em vários casos tais palavras foram utilizadas mais de uma vez pelo mesmo respondente. Neste sentido, o "Ser Trabalhador" se define pela relação de consumo estabelecida em sua atividade profissional. Destaca-se que em nenhuma das questões utilizadas para a análise desta categoria utilizou-se perguntas que estão associadas ao consumidor ou ao consumo.

Eu acho que são atividades diferentes, um pouco diferentes. Por exemplo, quando eu estou consumindo, eu mudo de posição e quando eu estou trabalhando, eu estou atendendo alguém que vai consumir alguma coisa, então... [...] é esses dois lados. Não sei se poderia dizer que... existe identificação entre busca e procura, mas eu acho que são dois lados um de busca e um de procura. (Entrevistado 34).

Outro ponto importante é que 11 entrevistados ( $12^{\circ}$ item da Tabela 32) estabelecem uma relação direta entre o "Ser Trabalhador" e o "Ser Consumidor". Tal vínculo mostra que suas experiências como consumidores ajudam a desenhar suas referências como trabalhadores. De forma análoga, foi possível perceber uma interligação entre o "Ser Trabalhador" e o "Ser Consumidor" por meio da definição "Ser mais exigente" (16 item da Tabela 32$)$, sendo que a expressão é comum nas duas categorias, como será visto.

Eu como consumidor eu sou muito exigente. É... eu num aceito erros, gosto das coisas bem feitas, se eu vou comprar alguma, se vou consumir alguma coisa e essa coisa está com defeito, num chego a reclamar no PROCON. Mas eu volto na empresa, eu reclamo. Só que, por outro lado, eu vejo se, às vezes, foi coisa mínima, também eu deixo passar, entendeu? Mas eu acho que, como consumidor, eu sou muito exigente.[...] (Como trabalhador, eu) sou exigente comigo mesmo. E eu fico sempre me cobrando, num 
deixo..., num gosto de fazer coisa errada, quando acontece uma coisa errada fico chateado, mas procuro corrigir, só que aí já fiquei chateado, você se abala um pouco, então eu sou muito exigente, nesse ponto entendeu? (Entrevistado 20).

[...] eu sou até mais exigente trabalhando do que como consumidor, acho que eu exijo mais de mim trabalhando do que com questão de consumo, quando eu vou comprar alguma coisa, nesse sentido. (Entrevistado 28).

O "Ser trabalhador" também se define a partir de se conseguir "Satisfazer o outro" $\left(19^{\circ}\right.$ item da Tabela 32), que no caso é o consumidor.

(Ser bancário) hoje você tem que estar, cada vez mais, deixando o seu cliente satisfeito com os seus produtos para que ele seja bem atendido e não vá procurar concorrente para ele estar atuando. (Entrevistado 26).

Outro ponto importante utilizado para a definição do "Ser Trabalhador" é o "Poder consumir" ( $22^{\circ}$ item da Tabela 32). O "Ser Trabalhador" que permite ação do consumo.

O trabalhador ele é um consumidor em potencial, porque a pessoa trabalha para conseguir uma renda, para conseguir uma coisa para se tornar um consumidor de outros estabelecimentos ou talvez do próprio onde trabalha. (Entrevistado 19). 
Tabela 32 - Quantidade de respondentes por tipo de citação na categoria de análise "Ser Trabalhador" - dados coletados nas agências bancárias de julho a outubro de 2007

O que é ser trabalhador para o bancário

1. Realizar ações diretamente associadas ao cliente/consumidor

2. Ser parceiro ou companheiro dos colegas bancários

3. Lidar com pessoas e estabelecer relacionamentos

4. Realizar atendimentos

5. Não ser unido ou coeso

6. Ser honesto, responsável, direito

7. Lidar com dinheiro

8. Ser competitivo/lidar com concorrência com colegas bancários

9. Trabalhar sob pressão ou estresse

10. Gostar do que faz

11. Vender

12. Tratar os clientes como gostaria de ser tratado

13. Ter status ou ser importante

14. Lidar com metas e resultados

15. Ser mais qualificado

16. Ser mais exigente

17. Ser metódico, rotineiro/trabalhar como se fosse uma máquina

18. Ser profissional

19. Satisfazer o outro

20. Ter comprometimento ou dedicação

21. Ter medo

22. Poder consumir

23. Ser valorizado

24. Ter desejo e volição

25. Ser consultor

26. Ajudar os outros

27. Realizar-se

28. Ter menor remuneração

29. Ser psicólogo

Fonte: Dados de pesquisa

Nota: Em destaque as definições que foram escolhidas como relevantes para o tema da pesquisa e que são analisadas em maior profundidade.

O Quadro 5 detalha analiticamente as definições dos bancários em três espectros diferentes.

No primeiro espectro, que se situa na segunda coluna do quadro, classifica-se a resposta pelo que ela está associada. As associações foram classificadas de acordo com as próprias falas. Encontrou-se seis tipos de associações:

- Papel social que o entrevistado desempenha: as respostas desta classificação estão associadas ao fato de que "Ser Trabalhador" corresponde a uma função ou papel em uma determinada relação social. Podem ser entendidas de forma que o "Ser Trabalhador" resulta em um papel social específico.

- Descrição de características da categoria profissional: estão enquadradas as frases que descrevem os bancários coletivamente. Tais respostas permitem ver não só 
como são vistos entre si, mas como são vistos pela sociedade na perspectiva coletiva.

- Descrição de como o trabalho é executado: descreve operacionalmente o que é feito pelo bancário no seu processo produtivo. Trata-se da execução cotidiana do trabalho como forma de definir o "Ser Trabalhador".

- Forma de atuação profissional: descreve características comportamentais do "Ser Trabalhador", que são definidas pela profissão.

- Sentimentos associados à atividade profissional: delineiam sentimentos citados como atrelados ao "Ser Trabalhador", característicos da profissão.

No segundo espectro de análise, terceira coluna do quadro, descreve-se qual referência é predominantemente utilizada para as definições feitas pelos respondentes. Encontrou-se cinco principais referências para tais definições:

- O colega de trabalho: o entrevistado utiliza os demais bancários de sua organização banco para definir o que é "Ser Trabalhador";

- Outras profissões: o respondente se vale da comparação da sua profissão com as demais em geral (não específicas) para estabelecer as definições;

- Profissão no passado: o bancário utiliza a comparação a sua própria profissão no passado para definir o que é "Ser Trabalhador" no contexto atual;

- O Cliente: a principal referência utilizada para definir o "Ser Trabalhador" é aquele que irá usufruir o trabalho bancário;

- Eu em contexto de consumo: a vivência do entrevistado como consumidor serve de referência para definir o "Ser Trabalhador".

No terceiro, última coluna, classifica se a referência predominante é utilizada em dois possíveis sentidos:

- Igualdade: o respondente estabelece que "Ser Trabalhador" é semelhante ou igual à referência utilizada para estabelecer a descrição. 
- Diferença: o respondente vale-se do argumento de que a referência utilizada é diferente ao "Ser Trabalhador". Neste sentido, a negação da referência define o que é o "Ser".

\section{Quadro 5 - Quadro de análise das respostas dos bancários para a categoria "Ser} Trabalhador"

\begin{tabular}{|c|c|c|c|}
\hline $\begin{array}{c}\text { O que é ser trabalhador para o } \\
\text { bancário }\end{array}$ & $\begin{array}{l}\text { Classificação da } \\
\text { resposta }\end{array}$ & $\begin{array}{c}\text { Referência predominante } \\
\text { utilizada para estabelecer } \\
\text { a Identidade }\end{array}$ & $\begin{array}{c}\text { Forma predominante } \\
\text { de estabelecer a } \\
\text { Identidade }\end{array}$ \\
\hline \begin{tabular}{|l} 
1. $\quad$ Realizar ações diretamente \\
associadas ao cliente/consumidor
\end{tabular} & Papel social & $\begin{array}{c}\text { Cliente } \\
\text { (outro-consumidor) }\end{array}$ & Diferença \\
\hline 2. Ser parceiro ou companheiro & $\begin{array}{l}\text { Descrição da categoria } \\
\text { profissional }\end{array}$ & $\begin{array}{l}\text { Colega de trabalho } \\
\text { (outro-trabalhador) }\end{array}$ & Igualdade \\
\hline $\begin{array}{l}\text { 3. Lidar com pessoas e estabelecer } \\
\text { relacionamentos }\end{array}$ & Descrição do trabalho & $\begin{array}{l}\text { Outras profissões } \\
\text { (outro-trabalhador) }\end{array}$ & Diferença \\
\hline 4. Realizar atendimentos & Descrição do trabalho & $\begin{array}{l}\text { Outras profissões } \\
\text { (outro-trabalhador) }\end{array}$ & Diferença \\
\hline 5. Não ser unido ou coeso & $\begin{array}{c}\text { Descrição da categoria } \\
\text { profissional }\end{array}$ & $\begin{array}{l}\text { Profissão no passado } \\
\text { (outro-trabalhador) }\end{array}$ & Diferença \\
\hline 6. Ser honesto, responsável, direito & $\begin{array}{l}\text { Forma de atuação } \\
\text { profissional }\end{array}$ & $\begin{array}{l}\text { Outras profissões } \\
\text { (outro-trabalhador) }\end{array}$ & Diferença \\
\hline 7. Lidar com dinheiro & Descrição do trabalho & $\begin{array}{l}\text { Outras profissões } \\
\text { (outro-trabalhador) }\end{array}$ & Diferença \\
\hline $\begin{array}{|lc|}8 . & \text { Ser competitivo ou lidar com } \\
\text { concorrência com colegas bancários }\end{array}$ & $\begin{array}{c}\text { Descrição da categoria } \\
\text { profissional }\end{array}$ & $\begin{array}{l}\text { Profissão no passado } \\
\text { (outro-trabalhador) }\end{array}$ & Diferença \\
\hline 9. Trabalhar sob pressão/estresse & $\begin{array}{l}\text { Sentimento associado à } \\
\text { atividade profissional }\end{array}$ & $\begin{array}{l}\text { Profissão no passado } \\
\text { (eu/outro-trabalhador) }\end{array}$ & Diferença \\
\hline 10. Gostar do que faz & $\begin{array}{l}\text { Jeito de ser do } \\
\text { profissional }\end{array}$ & $\begin{array}{l}\text { Colega de trabalho } \\
\text { (outro-trabalhador) }\end{array}$ & Diferença \\
\hline 11. Vender & Descrição do trabalho & $\begin{array}{l}\text { Outras profissões } \\
\text { (outro-trabalhador) }\end{array}$ & Diferença \\
\hline $\begin{array}{l}\text { 12. Tratar os clientes como gostaria } \\
\text { de ser tratado }\end{array}$ & $\begin{array}{l}\text { Forma de atuação } \\
\text { profissional }\end{array}$ & $\begin{array}{l}\text { Eu em outra situação } \\
\text { (eu-consumidor) }\end{array}$ & Igualdade \\
\hline 13. Ter status ou ser importante & $\begin{array}{c}\text { Descrição da categoria } \\
\text { profissional }\end{array}$ & $\begin{array}{l}\text { Profissão no passado } \\
\text { (eu/outro-trabalhador) }\end{array}$ & Diferença \\
\hline 14. Lidar com metas e resultados & Descrição do trabalho & $\begin{array}{l}\text { Outras profissões } \\
\text { (outro-trabalhador) }\end{array}$ & Diferença \\
\hline 15. Ser mais qualificado & $\begin{array}{c}\text { Jeito de ser do } \\
\text { profissional }\end{array}$ & $\begin{array}{l}\text { Profissão no passado } \\
\text { (outro-trabalhador) }\end{array}$ & Diferença \\
\hline 16. Ser mais exigente & $\begin{array}{l}\text { Forma de atuação } \\
\text { profissional }\end{array}$ & $\begin{array}{l}\text { Eu em outro contexto } \\
\text { (eu-consumidor) }\end{array}$ & Igualdade \\
\hline $\begin{array}{l}\text { 17. Ser metódico, rotineiro ou } \\
\text { trabalhar como se fosse uma máquina }\end{array}$ & $\begin{array}{l}\text { Forma de atuação } \\
\text { profissional }\end{array}$ & $\begin{array}{l}\text { (outro-trabalhador) } \\
\text { Outras profissões }\end{array}$ & Diferença \\
\hline 18. Ser profissional & $\begin{array}{c}\text { Forma de atuação } \\
\text { profissional }\end{array}$ & $\begin{array}{l}\text { (outro-trabalhador) } \\
\text { Colega de trabalho }\end{array}$ & Diferença \\
\hline 19. Satisfazer o outro & $\begin{array}{l}\text { Sentimento associado à } \\
\text { atividade profissional }\end{array}$ & $\begin{array}{l}\text { Eu em outro contexto } \\
\text { (eu-consumidor) }\end{array}$ & Igualdade \\
\hline 20. Comprometimento dedicação & $\begin{array}{l}\text { Forma de atuação } \\
\text { profissional }\end{array}$ & $\begin{array}{l}\text { Colega de trabalho } \\
\text { (outro-trabalhador) }\end{array}$ & Diferença \\
\hline 21. Ter medo & $\begin{array}{l}\text { Sentimento associado à } \\
\text { atividade profissional }\end{array}$ & $\begin{array}{l}\text { Profissão no passado } \\
\text { (outro-trabalhador) }\end{array}$ & Diferença \\
\hline 22. Poder consumir & Papel social & $\begin{array}{l}\text { Outras profissões } \\
\text { (outro-trabalhador) }\end{array}$ & Igualdade \\
\hline 23. Ser valorizado & $\begin{array}{c}\text { Descrição da categoria } \\
\text { profissional }\end{array}$ & $\begin{array}{l}\text { Outras profissões } \\
\text { (outro-trabalhador) }\end{array}$ & Diferença \\
\hline
\end{tabular}




\begin{tabular}{|c|c|c|c|}
\hline $\begin{array}{c}\text { O que é ser trabalhador para } 0 \\
\text { bancário }\end{array}$ & $\begin{array}{l}\text { Classificação da } \\
\text { resposta }\end{array}$ & $\begin{array}{c}\text { Referência predominante } \\
\text { utilizada para estabelecer } \\
\text { a Identidade }\end{array}$ & $\begin{array}{c}\text { Forma predominante } \\
\text { de estabelecer a } \\
\text { Identidade }\end{array}$ \\
\hline 24. Ter desejo e volição & $\begin{array}{l}\text { Jeito de ser do } \\
\text { profissional }\end{array}$ & $\begin{array}{l}\text { Colega de trabalho } \\
\text { (outro-trabalhador) }\end{array}$ & Diferença \\
\hline 25. Ser consultor & Descrição do trabalho & $\begin{array}{l}\text { Outras profissões } \\
\text { (outro-trabalhador) }\end{array}$ & Igualdade \\
\hline 26. Ajudar os outros & Papel social & $\begin{array}{c}\text { O outro na relação de } \\
\text { produção (eu-consumidor) }\end{array}$ & Diferença \\
\hline 27. Realizar-se & $\begin{array}{c}\text { Sentimento associado à } \\
\text { atividade profissional }\end{array}$ & $\begin{array}{l}\text { Colega de trabalho } \\
\text { (outro-trabalhador) }\end{array}$ & Diferença \\
\hline 28. Ter menor remuneração & $\begin{array}{c}\text { Descrição da categoria } \\
\text { profissional }\end{array}$ & $\begin{array}{l}\text { Profissão no passado } \\
\text { (outro-trabalhador) }\end{array}$ & Diferença \\
\hline 29. Ser psicólogo & Descrição do trabalho & $\begin{array}{l}\text { Outras profissões } \\
\text { (outro-trabalhador) }\end{array}$ & Igualdade \\
\hline
\end{tabular}

Fonte: Dados de pesquisa

Nota: Em destaque as definições que foram escolhidas como relevantes para o tema da pesquisa e que são analisadas em maior profundidade.

Os três espectros de análise permitem compreender como as definições explicam o "Ser Trabalhador". Na definição "Realizar ações diretamente associadas ao cliente/consumidor" ( $1^{\circ}$ item do Quadro 5), o "Ser Trabalhador" é o que ocupa o papel social diferente do consumidor/cliente. Ou seja, "Ser Trabalhador" é definido por estar, em termos de papéis sociais, em situações opostas. É a oposição de papéis com o consumidor que o define como ser bancário.

A descrição "Tratar os clientes como gostaria de ser tratado" (12 item do Quadro 5), estabelece um sentido de Igualdade com a situação de "Ser consumidor", na forma como o profissional atua. Em outras palavras, "Ser Trabalhador" estabelece um paralelo, em termos do resultado de sua atuação profissional, entre o eu-trabalhador e o eu-consumidor. Neste sentido, sua forma de atuar depende de suas expectativas e experiências como consumidor para que tais igualdades possam ser estabelecidas.

O $16^{\circ}$ item do Quadro 5, "Ser mais exigente" funciona de forma análoga à descrição citada anteriormente. $\mathrm{O}$ respondente estabelece um padrão de igualdade com ele mesmo como consumidor, em termos da forma como atua profissionalmente. É como se o "Ser Trabalhador" se definisse como "Ser mais exigente" à medida que sua experiência como consumidor também o tornou mais exigente, e vice-versa.

(Como bancário, eu sou) exigente, acho que do jeito que eu gosto de passar uma clareza para o consumidor na minha frente, eu também quero essa clareza e confiança. (Entrevistado 08).

Hoje, eu sou muito exigente, muito, mas muito extremo. Até sou rotulado aí pela minha 
filha, minha mulher, isso não precisava fazer isso, releva, mas acho que são assim em relação aquilo que eu sou cobrado e aquilo que eu presto de serviço, eu dou o máximo de mim, eu procuro a satisfação completa mesmo... (Entrevistado 16).

Eu sou muito exigente, muito exigente, porque a gente trabalha recendo muita cobrança. Eu passei a ser inteligente com tudo, tudo que eu vou comprar. Sempre sou exigente, sempre vou querer procurar, pesquisar, vou querer o melhor. (Entrevistado 17).

Eu como consumidor, eu sou exigente. Eu gosto de ser bem atendido. Tem algumas coisas que se a gente não sabe fazer e pede explicação... eu gosto de ser bem explicado. Eu acho que a gente faz isso no trabalho, a gente acaba exigindo isso em retorno. Eu pesquiso bastante preço. Acho que hoje é uma coisa que a gente tem bastante diferença de preço nos lugares que você vai. E eu gosto de consumir muito da minha cidade, acho que para valorizar o lugar que eu moro. [...] Como bancário eu sou, acho que exigente até comigo mesmo no atendimento ao meu público, que como eu exijo também. Eu como consumidor, ele por outro, como consumidor, eu tenho que estar atendendo todas as necessidades dele, e tento fazer o máximo. Eu dou o meu máximo dentro da minha parte profissional. (Entrevistado 26).

"Satisfazer o outro" (19 item do Quadro 5) é uma descrição que o entrevistado estabelece uma referência de igualdade com o sentimento que tem quando está na posição de euconsumidor. Mais uma vez, suas experiências como consumidor definem seu "Ser Trabalhador".

Então, quando eu estou trabalhando, a forma que o banco faz com que a gente trabalhe, a gente tem sempre que deixar a pessoa satisfeita. Só que como consumidora, eu vejo que sempre não é assim. O que eu quero, o que eu preciso, tanto faz, só mais uma ali. Sem dá muita importância para o que eu preciso. (Entrevistado 17).

O "Ser Consumidor" também é associado ao "Ser Trabalhador" por meio da descrição "Poder Consumir" (22 item do Quadro 5). A referência utilizada são os trabalhadores de uma forma geral e o entrevistado estabelece uma relação de igualdade, no sentido de que o acesso ao papel social de consumidor só é permitido a quem trabalha. Ser igual aos outros trabalhadores é ter acesso ao consumo, é poder "Ser consumidor".

A análise das entrevistas mostrou que a construção do "Ser Trabalhador" estabelece relações mais complexas de igualdade e/ou diferença entre o eu-trabalhador e: a) o outro trabalhador (no passado, colega de banco, ou demais profissões); b) o eu-consumidor e; c) o outroconsumidor (Vide Quadro 6). Com isso, percebe-se que há influência da vivência como consumidor e da convivência com consumidores, na definição desta categoria de análise, segundo a fala dos entrevistados.

Em alguns casos, também foi possível observar que a definição do "Ser Trabalhador" é construída estabelecendo uma relação de distinção entre os bancários do interior e os 
bancários da capital. Os bancários da capital são mencionados como mais mobilizados em termos sindicais, podendo ser considerada como uma especificação geográfica da referência eu-trabalhador. Entretanto, apenas um entrevistado mencionou tal questão, podendo se configurar como uma visão particular sobre o fato, até que novos estudos sejam realizados.

Quadro 6 - Quadro de análise das referências encontradas para descrever o "Ser Trabalhador"

\begin{tabular}{|c|c|c|c|}
\hline & $\begin{array}{c}\text { Forma de estabelecer a } \\
\text { relação }\end{array}$ & Referências & Especificação da Referência \\
\hline \multirow{10}{*}{ 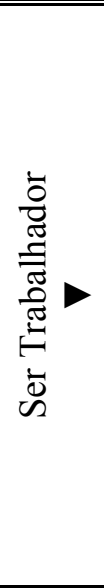 } & $\neq$ & Eu trabalhador & No passado \\
\hline & $\neq$ & Outro trabalhador & No passado \\
\hline & $=$ & Outro trabalhador & Colega de banco \\
\hline & $\neq$ & Outro trabalhador & Colega de banco \\
\hline & $=$ & Outro trabalhador & Outras profissões \\
\hline & $\neq$ & Outro trabalhador & Outras profissões \\
\hline & $=$ & Eu consumidor & Fora do banco \\
\hline & $\neq$ & Eu consumidor & Fora do banco \\
\hline & $=$ & Outro consumidor & Cliente do banco \\
\hline & $\neq$ & Outro consumidor & Cliente do banco \\
\hline
\end{tabular}

Fonte: Análise dos dados

\subsection{SER CONSUMIDOR}

Para a categoria "Ser Consumidor", encontrou-se 19 definições ao longo dos discursos que foram citadas por mais de um respondente (Vide Tabela 33). Da mesma forma que na categoria de análise anterior, algumas definições podem ter antíteses ou frases negativas.

Dentro da análise desta pesquisa, são trabalhadas em maior profundidade, as definições do "Ser Consumidor" que possuem relação estreita como o "Ser Trabalhador". A definição "Ser exigente" ( $1^{\circ}$ item da Tabela 33) foi citada por 19 entrevistados e está relacionada à categoria "Ser Trabalhador", na medida em que foi igualmente citada naquela categoria e pelo fato de que houve conexões entre as duas definições pelos respondentes.

Como trabalhador talvez eu não consiga exigir a mesma coisa que eu exijo como consumidor. Como eu falei antes, às vezes eu sou obrigado a tomar algumas atitudes, às vezes o sistema acaba me jogando numa situação, que se eu fosse consumidor não chegaria a isso. Então eu acho que como consumidor você pode dar o grito, porque é você atrás do seu direito, você tem esse direito[...] (Entrevistado 08).

Eu, quando eu era só consumidora, talvez eu fosse, eu num tratava com falta de cortesia, eu acho que eu nunca tratei ninguém. Mas o fato de trabalhar do lado de cá, no 
backoffice, isso me torna uma consumidora melhor, mais noção do que é dever e do que é direito. A maioria das pessoas não consegue fazer esse gancho, porque não vivenciou os dois lados, então trabalhar no banco, está ali na linha de tiro, que é bem isso mesmo, ele me faz perceber o outro lado, que é o lado do consumidor, que ele me faz um consumidor melhor. (Entrevistado 15).

Acho que eu sou até mais exigente trabalhando do que como consumidor, acho que eu exijo mais de mim trabalhando do que com questão de consumo, quando eu vou comprar alguma coisa, nesse sentido. (Entrevistado 28).

Eu sou exigente, muito exigente. [...] Muito exigente no resultado. (Entrevistado 29).

Esta última entrevistada, ao ser perguntada se o consumidor afeta na definição de quem ela é, fez uma conexão entre o consumidor ser exigente e ela ser exigente.

Ah, eu acho que sim (o consumidor a define). Nessa visão eu acho que sim. Eu acho que todo mundo, nesse ponto, se torna exigente nessas coisas. (Entrevistado 29).

Outra definição que foi muito citada é "Ser controlado ou criterioso na hora de consumir" $\left(2^{\circ}\right.$ item da Tabela 33), com 18 respondentes. A ligação dessa definição com o "Ser Trabalhador" advém do fato de que o bancário lida com pessoas endividadas, que chegaram a tal situação por extrapolar os limites de sua condição financeira.

Porque a gente como bancária, têm muitas pessoas que você vê que não têm controle. A maioria dos casos, que vai nos bancos são pessoas que não têm controle, e não são pessoas que têm planejamento, sem planejamento mesmo. E são pessoas que vão consumindo, se endividando, não conhece mesmo os procedimentos bancários, a forma de trabalhar com cartão de crédito, a forma de fazer que seja um leasing, um empréstimo pessoal, as pessoas não entendem, e as pessoas estão cada vez mais se endividando, se enrolando. (Entrevistado 46).

A definição do "Ser Consumidor" como "Ser hostil, brigar, xingar ou nervoso na hora de consumir" ( $4^{\circ}$ item da Tabela 33), com 15 respondentes, é sempre descrita na condição de trabalhador que sofre a agressão. Entretanto, a vivência com esse tipo de situação cria paralelos no eu-trabalhador e no eu-consumidor.

[...] eu como trabalhador eu não sou agressivo, e como consumidor eu também não sou agressivo, eu caio na coluna do meio em ambas as partes, eu acho que seria isso. (Entrevistado 05).

[...] tem aquele cliente que chega achando que... ele pega todos os problemas dele, que ele tem em casa, que ele tem no serviço dele, que ele tem... que ele xingou o guarda na rua, que ele tomou uma multa de trânsito, que o cara buzinou atrás dele, ele traz para dentro do banco, senta na mesa e descarrega tudo em você. Aí você tem que saber filtrar todos esses tipos de clientes: o cliente que chega te xingando, você deixa entrar num ouvido e sair pelo outro, atende ele bem, para ver se quando ele chegar em casa ele põe a cabeça no lugar e não faz mais aquilo. (Entrevistado 02). 
Existe a pessoa sem informação, que a pessoa que vai buscar informação e tem o tirano, o cliente, que a gente brinca que tem a tirania do consumidor. Se você olha para ele e piscar o olho, ele liga pro PROCON. Então, eu vejo dois clientes, o cliente que precisa de ajuda e o cliente inimigo. (Entrevistado 15).

Para nove dos entrevistados, a condição de existência do "Ser Trabalhador" é determinada pelo "Ser Consumidor" (10 item da Tabela 33).

Hoje quem dita as regras é o cliente. Então a gente tem que prever o cliente, tem que ver o cliente, como o seguinte: é ele que vai determinar se eu vou trabalhar nesse ramo mais algum tempo ou não. A gente vê muita coisa aqui... (Entrevistado 04).

[...] mas os clientes que a gente tem reclamação, são poucos. Têm muitos que ficam quietos, calados, então a gente leva em conta aquele que reclama. Na verdade os outros são a grande maioria, eu acho que nós dependemos deles para existir. (Entrevistado 44).

Enquanto que o "Ser Trabalhador" se estressa, o "Ser Consumidor" pode "Desestressar" (16 item da Tabela 33). Os três entrevistados que citaram, expressam como forma de compensar pelo trabalho.

[...] então realmente é um trabalho estressante e é uma coisa... você trabalha com dinheiro e com pessoas, que são duas coisas bem complicadas. Mexeu no bolso da pessoa [...] O consumo, às vezes, me dá um pouquinho, uma relaxada. Às vezes, você está meio... tem um dia estressado, daí você chega e fala: puxa hoje eu mereço alguma coisa. Entro na Internet e compro uma pequena lembrançinha. Mas eu gosto, gosto sim de consumir. (Entrevistado 07).

[...] você tem que ter alguma coisa para você, para tirar o seu estresse, para você, então você tendo uma necessidade não sendo doença, sendo consumo, eu acho que você tem uma necessidade de consumir além daquilo da sua necessidade, não que aquilo, não seja fútil. (Entrevistado 25).

"Ser Consumidor" é "Ter sempre razão" para dois entrevistados. E ter razão em relação àquele que está do outro lado do processo de consumo-produção. $\mathrm{O}$ entrevistado vale-se do ditado para se expressar.

[...] tem aquele ditado que o cliente sempre tem a razão (Entrevistado 44).

Outro paralelo que é estabelecido entre as duas categorias de análise, "Ser Trabalhador e "Ser Consumidor", é a procura de reciprocidade no relacionamento social que se estabelece na situação de consumo e produção. Ao expressar que quer "Ser tratado como trata" (29 item da Tabela 33), ele está fazendo uma transposição entre o eu-trabalhador e o eu-consumidor.

Eu vejo que quando eu vou a algum lugar como consumidora, eu quero ter um tratamento da mesma forma que eu trato os meus clientes aqui dentro (do nome do banco), que é com respeito, com educação e querendo atender aquelas necessidades, aqueles desejos. (Entrevistado 33). 
Eu tento não ser diferente então, por exemplo, é tratar as pessoas como eu gostaria que fossem tratadas, então se eu chego em um lugar, gostaria que as pessoas fossem atendidas como eu atendo as pessoas. (Entrevistado 36).

Tabela 33 - Quantidade de respondentes por tipo de citação na categoria de análise "Ser Consumidor" - dados coletados nas agências bancárias de julho a outubro de 2007

\begin{tabular}{|c|c|c|}
\hline O que é ser consumidor para o bancário & Quantidade & Freqüência \\
\hline 1. Ser exigente & 19 & $38 \%$ \\
\hline 2. Ser controlado ou criterioso na hora de comprar & 18 & $36 \%$ \\
\hline 3. Ser compulsivo ou impulsivo na hora de consumir & 15 & $30 \%$ \\
\hline 4. Ser hostil, brigar, xingar ou nervoso na hora de consumir & 15 & $30 \%$ \\
\hline 5. Se sentir importante ou ter poder na hora de consumir & 14 & $28 \%$ \\
\hline 6. Consumir está ligado a uma necessidade & 13 & $26 \%$ \\
\hline 7. Gostar de comprar & 12 & $24 \%$ \\
\hline 8. Sentir prazer, felicidade ou satisfação & 11 & $22 \%$ \\
\hline 9. Ser consumista & 10 & $20 \%$ \\
\hline 10. Determinar o "Ser Trabalhador" & 9 & $18 \%$ \\
\hline 11. Comprar mais do precisa & 9 & $18 \%$ \\
\hline 12. Gostar de qualidade e preço & 7 & $14 \%$ \\
\hline 13. Ser mais esclarecido e consciente hoje & 7 & $14 \%$ \\
\hline 14. Pesquisar & 5 & $10 \%$ \\
\hline 15. Ser diferente & 5 & $10 \%$ \\
\hline 16. Desestressar & 3 & $9 \%$ \\
\hline 17. Ser racional na hora de consumir & 2 & $4 \%$ \\
\hline 18. Ter sempre a razão & 2 & $4 \%$ \\
\hline 19. Ser tratado como trata & 2 & $4 \%$ \\
\hline
\end{tabular}

Fonte: Dados de pesquisa

Nota: Em destaque as definições que foram escolhidas como relevantes para o tema da pesquisa e que são analisadas em maior profundidade.

O Quadro 7 analisa as definições dos bancários nos mesmos espectros que a categoria de análise anterior. Entretanto, as associações são distintas. Em termos de classificação das respostas, segunda coluna do quadro, encontrou-se seis tipos distintos:

- Forma de atuação como consumidor: que descreve o comportamento do consumidor segundo as definições dos próprios entrevistados.

- Papel social que o consumidor desempenha: são os papéis que o "Ser Consumidor" desempenha no contexto social na relação com os outros. As definições que expressam o "Ser Consumidor" no contexto social, na relação com os outros indivíduos.

- Característica do consumidor: apenas uma definição se enquadrou nesta associação ligada à descrição do consumidor em si.

- Função do consumo: são as definições que descrevem o porquê consumir. 
- Preferências de consumo: definem as expectativas que o entrevistado tem como consumidor.

- Sentimento em relação ao consumo: são ligadas ao que sente o entrevistado ao consumir e que são definidoras do "Ser Consumidor" na concepção dos entrevistados.

Os demais espectros de análise foram semelhantes aos utilizados na categoria anterior.

Quadro 7 - Quadro de análise das respostas dos bancários para a categoria "Ser Trabalhador"

\begin{tabular}{|c|c|c|c|}
\hline $\begin{array}{c}\text { O que é ser consumidor para } \\
\text { o bancário }\end{array}$ & $\begin{array}{l}\text { Classificação da } \\
\text { resposta }\end{array}$ & $\begin{array}{c}\text { Referência predominante } \\
\text { utilizada para estabelecer } \\
\text { a Identidade } \\
\end{array}$ & $\begin{array}{c}\text { Forma predominante } \\
\text { de estabelecer a } \\
\text { Identidade } \\
\end{array}$ \\
\hline 1. Ser exigente & $\begin{array}{l}\text { Forma de atuação como } \\
\text { consumidor }\end{array}$ & outro-consumidor & Igualdade \\
\hline $\begin{array}{l}\text { 2. Ser controlado ou criterioso } \\
\text { na hora de comprar }\end{array}$ & $\begin{array}{l}\text { Forma de atuação como } \\
\text { consumidor }\end{array}$ & outro-consumidor & Diferença \\
\hline $\begin{array}{l}\text { 3. Ser compulsivo ou impulsivo } \\
\text { na hora de consumir }\end{array}$ & $\begin{array}{l}\text { Forma de atuação como } \\
\text { consumidor }\end{array}$ & outro-consumidor & Diferença \\
\hline $\begin{array}{l}\text { 4. Ser hostil, brigar, xingar ou } \\
\text { ser nervoso na hora de consumir }\end{array}$ & $\begin{array}{c}\text { Forma de atuação como } \\
\text { consumidor }\end{array}$ & outro-consumidor & Diferença \\
\hline $\begin{array}{l}\text { 5. Se sentir importante ou ter } \\
\text { poder na hora de consumir }\end{array}$ & Papel social & outro-consumidor & Igualdade \\
\hline $\begin{array}{l}\text { 6. Consumir está ligado a uma } \\
\text { necessidade }\end{array}$ & Função do consumo & outro-consumidor & Diferença \\
\hline 7. Gostar de comprar & $\begin{array}{c}\text { Sentimento em relação ao } \\
\text { consumo }\end{array}$ & outro-consumidor & Diferença \\
\hline $\begin{array}{l}\text { 8. Sentir prazer, felicidade ou } \\
\text { satisfação }\end{array}$ & $\begin{array}{c}\text { Sentimento em relação ao } \\
\text { consumo }\end{array}$ & Não determinado* & Não determinado* \\
\hline 9. Ser consumista & $\begin{array}{l}\text { Forma de atuação como } \\
\text { consumidor }\end{array}$ & outro-consumidor & Diferença \\
\hline $\begin{array}{l}\text { 10. Determinar o Ser } \\
\text { Trabalhador }\end{array}$ & Papel social & outro-trabalhador & Diferença \\
\hline 11. Comprar mais do precisa & $\begin{array}{l}\text { Forma de atuação como } \\
\text { consumidor }\end{array}$ & outro-consumidor & Diferença \\
\hline 12. Gostar de qualidade e preço & Preferências de consumo & outro-consumidor & Igualdade \\
\hline $\begin{array}{l}\text { 13. Ser mais esclarecido e } \\
\text { consciente hoje }\end{array}$ & $\begin{array}{l}\text { Característica do } \\
\text { consumidor }\end{array}$ & outro-consumidor & Diferença \\
\hline 14. Pesquisar & $\begin{array}{l}\text { Forma de atuação como } \\
\text { consumidor }\end{array}$ & outro-consumidor & Diferença \\
\hline 15. Ser diferente & Papel social & outro-consumidor & Diferença \\
\hline 16. Desestressar & Função do consumo & eu-trabalhador & Diferença \\
\hline $\begin{array}{l}\text { 17. Ser racional na hora de } \\
\text { consumir }\end{array}$ & $\begin{array}{c}\text { Forma de atuação como } \\
\text { consumidor }\end{array}$ & outro-consumidor & Diferença \\
\hline 18. Ter sempre a razão & Papel social & outro-trabalhador & Diferença \\
\hline 19. Ser tratado como trata & Preferências de consumo & eu-trabalhador & Igualdade \\
\hline
\end{tabular}

Fonte: Dados de pesquisa

Nota: Em destaque as definições que foram escolhidas como relevantes para o tema da pesquisa e que são analisadas em maior profundidade. Os itens assinalados com asterisco não foram determinados porque os discursos ora não mencionavam ora descreviam referências distintas, não havendo predominância. 
Na definição "Ser exigente" (1 ${ }^{\circ}$ item do Quadro 7), o entrevistado estabelece uma relação de igualdade entre o eu-consumidor e o outro-consumidor em termos da forma como atua. A definição "Ser exigente" foi utilizada de forma enfática ao definirem o "Ser Consumidor" e o "Ser Trabalhador". Ou seja, há associações entre o ser exigente como consumidor e a atividade laboral.

Os respondentes utilizam a definição "Ser controlado ou criterioso na hora de comprar" $\left(2^{\circ}\right.$ item do Quadro 7) no sentido de estabelecer uma diferença com os outros-consumidores com quem convivem em termos da forma como consomem, principalmente no contexto bancário. A experiência de conviver com endividados os faz mais controlados.

Também é estabelecida uma diferença com o outro-consumidor na forma de atuação como consumidor ao utilizarem a definição "Ser hostil, brigar, xingar ou ser nervoso na hora de consumir" ( $4^{\circ}$ item do Quadro 7). A convivência com a hostilidade os faz pronunciar que não são agressivos como consumidores, que são diferentes, pois entendem que não deveriam ser agredidos, pois trata-se de uma injustiça por parte do consumidor.

Ao citar elementos que configurem como "Determinar o Ser Trabalhador" ( $10^{\circ}$ item do Quadro 7), o respondente estabelece uma diferença de papel social em relação ao outrotrabalhador, de forma que um só exista na dependência do outro.

O eu-consumidor se distingue do eu-trabalhador na definição "Desestressar" (16 $16^{\circ}$ item do Quadro 7) em termos da função do consumo para o entrevistado. O "Ser Consumidor" desestressa em relação ou em compensação ao "Ser Trabalhador".

Em termos de papel social, o eu-consumidor vai "Ter sempre a razão" em relação ao outrotrabalhador, estabelecendo, neste sentido, as diferenças. Os dois estão em lados opostos em relação à "razão".

No $19^{\circ}$ item do Quadro 7, "Ser tratado como trata", o entrevistado expressa sua preferência de consumo interligando o seu eu-consumidor com o eu-trabalhador. É interessante associar a definição do "Ser Trabalhador" como "Tratar como gostaria de ser tratado".

A análise desta categoria mostrou que há associações diretas entre o "Ser Consumidor" e o "Ser trabalhador" na concepção dos entrevistados. Além disso, tais associações estão ligadas ao movimento de valorização do consumo e do consumidor no contexto atual. Frases como "o 
cliente tem sempre razão", "o cliente é tudo para a empresa", "quem paga meu salário é o cliente" denotam a presença deste contexto.

\subsection{ELEMENTOS DE EXPRESSÃO DA IDENTIDADE SOCIAL}

Esta categoria procura avaliar quais elementos discursivos os entrevistados utilizam para exprimir sua Identidade Social. Neste sentido, são avaliadas as referências que o entrevistado usa para falar de si para os outros e os processos de identificações com os elementos desta pesquisa.

Para as referências que utiliza para falar si, utilizou-se uma questão que solicita que ele mostre como se apresenta no ambiente social (contexto externo) em que convive e uma questão que solicita que ele expresse como se apresentaria para um membro de sua família mais próximo (contexto familiar íntimo).

Na primeira questão, detalhada pela Tabela 34, que trata do contexto externo, a referência mais utilizada para que o entrevistado se apresente socialmente é "A organização em que trabalha" com 28 respondentes. O bancário expressa, em muitos casos, que é conhecido com o sobrenome associado ao nome da organização.

(Nome do entrevistado) do (Nome do banco). Eu me identifico muito com o meu nome e sobrenome. (Entrevistado 03).

Ela me dá identidade, com certeza. Eu diria que às vezes hoje o meu sobrenome é (Nome do Banco). (Entrevistado 27).

Sou o (Nome do entrevistado) do (Nome do banco), normalmente a gente se define assim, o banco passou a ser o sobrenome da gente. (Entrevistado 12).

No que eu trabalho, eu costumo brincar que eu tenho nome, (Nome do entrevistado) $e$ sobrenome (Nome do banco). (Entrevistado 47).

(Nome do entrevistado), gerente do (Nome do banco), ou (Nome do entrevistado) do (Nome do banco). Sou bastante conhecido como (Nome do entrevistado) do (Nome do banco). (Entrevistado 48).

Outros elementos bastante utilizados pelos entrevistados para se identificar são suas "Características pessoais", com 12 bancários citando tais elementos. Tais características envolvem, traços físicos, comportamentos, sentimentos e emoções que são sui generis à pessoa respondente. A família foi a terceira mais citada como referência social, compreendendo sete entrevistados. As demais referências foram citadas individualmente, 
tendo destaque que apenas um citou a categoria profissional como referência.

Tabela 34 - Distribuição dos respondentes da pesquisa por resposta à pergunta "Quando as pessoas perguntam quem é você, o que utiliza como referência para explicar quem é?" - dados coletados nas agências bancárias de julho a outubro de 2007

\begin{tabular}{l|c|c}
\hline Categorias & Quantidade & Freqüência \\
\hline A organização em que trabalha & 28 & $56 \%$ \\
Características pessoais & 12 & $24 \%$ \\
A família & 07 & $14 \%$ \\
Categoria profissional dos bancários & 01 & $02 \%$ \\
Curso de formação no ensino superior & 01 & $02 \%$ \\
Atividades extra-trabalho & 01 & $02 \%$ \\
\hline Total & $\mathbf{5 0}$ & $\mathbf{1 0 0} \%$ \\
\hline \hline
\end{tabular}

Fonte: Dados de pesquisa

Na segunda questão, que fala do contexto familiar íntimo, cujos dados estão tabulados na Tabela 35, a referência mais citada é que o entrevistado "Fala o nome da organização em que trabalha" com 17 respondentes. Outros 15 trabalhadores se referenciaram como bancários para seus filhos. Oito entrevistados descrevem o trabalho que executa no cotidiano e três falam do resultado social do seu trabalho.

Tabela 35 - Distribuição dos respondentes da pesquisa por resposta à pergunta "O que você diz para seu filho sobre quem você é e o que você faz?" - dados coletados nas agências bancárias de julho a outubro de 2007

\begin{tabular}{|c|c|c|}
\hline Categorias & $\overline{\text { Quantidade }}$ & Freqüência \\
\hline Fala o nome da organização em que trabalha & 17 & $34 \%$ \\
\hline Fala que é bancário & 15 & $30 \%$ \\
\hline Descreve o trabalho que executa & 08 & $16 \%$ \\
\hline Fala do resultado social do seu trabalho & 03 & $06 \%$ \\
\hline Fala o curso superior em que se formou & 02 & $04 \%$ \\
\hline Outras respostas associadas ao trabalho & 03 & $06 \%$ \\
\hline Outras respostas não-associadas ao trabalho & 02 & $04 \%$ \\
\hline Total & 50 & $100 \%$ \\
\hline
\end{tabular}

Fonte: Dados de pesquisa

Analisando as duas questões em conjunto, percebe-se que a organização é utilizada como referência para 38 entrevistados, sendo que sete respondentes utilizam duplamente, no contexto externo e no contexto familiar íntimo. Dentre os 50 bancários pesquisados, $48 \mathrm{em}$ algum momento fazem uma referência ou ao trabalho, ou à organização ou à categoria profissional, sendo que em diversos casos tais elementos são citados mais de uma vez pelo mesmo respondente. Neste sentido, apenas 02 entrevistados não fazem qualquer menção a aspectos ligados ao trabalho como referência de si mesmo. A Tabela 36 detalha essas informações. 
Tabela 36 - Distribuição dos respondentes da pesquisa por "Referências mais citadas nas questões de Identidade" - dados coletados nas agências bancárias de julho a outubro de 2007

\begin{tabular}{|c|c|c|}
\hline Categorias & Quantidade & Freqüência \\
\hline $\begin{array}{l}\text { Fala o nome da organização em que trabalha ou para os filhos ou para } \\
\text { alguém na rua }\end{array}$ & 38 & $76 \%$ \\
\hline $\begin{array}{l}\text { Fala o nome da organização em que trabalha para os filhos e para } \\
\text { alguém na rua }\end{array}$ & 07 & $14 \%$ \\
\hline Fala que é bancário ou para os filhos ou para alguém na rua & 16 & $32 \%$ \\
\hline $\begin{array}{l}\text { Fazem menção a aspectos diretamente associados ao trabalho como } \\
\text { referência para sua Identidade }\end{array}$ & 48 & $96 \%$ \\
\hline $\begin{array}{l}\text { Não fazem qualquer menção do trabalho como referência para sua } \\
\text { Identidade }\end{array}$ & 02 & $04 \%$ \\
\hline
\end{tabular}

Fonte: Dados de pesquisa

\subsubsection{Expressão da Identidade, identificação e trabalho}

No que diz respeito aos processos de expressão da Identidade e de identificação, procurou-se compreender se esses aconteciam em relação ao trabalho, em relação à categoria profissional e em relação à organização.

Quando questionados sobre o trabalho, entre os entrevistados, a grande maioria (47 respondentes) se identifica com sua atividade laboral e três bancários apenas responderam que não se identificam (Vide Tabela 37). Os que responderam que não se identificam não deram motivos específicos para sua resposta, entretanto, sabe-se, em comentários após a finalização das entrevistas, que todos possuem projetos pessoais associados a outro tipo de profissão que já estão em andamento.

Tabela 37 - Distribuição dos respondentes da pesquisa por resposta à pergunta "Você se identifica com seu trabalho?" - dados coletados nas agências bancárias de julho a outubro de 2007

\begin{tabular}{l|c|c}
\hline Categorias & Quantidade & Freqüência \\
\hline Sim & 47 & $94 \%$ \\
Não & 03 & $06 \%$ \\
\hline Total & $\mathbf{5 0}$ & $\mathbf{1 0 0} \%$ \\
\hline \hline
\end{tabular}

Fonte: Dados de pesquisa

Quando questionados se o trabalho afeta na definição de quem eles são (Vide Tabela 38), 48 entrevistados afirmaram que sim e apenas dois que não. Um dos que afirmaram que não, acredita que é preciso manter uma certa personalidade, independente do trabalho. Entretanto, reconhece que o trabalho mudou o seu jeito de ser. $\mathrm{O}$ outro entrevistado nada mencionou 
sobre o assunto.

Não, não. Ele me ajuda porque graças ao meu trabalho eu tenho posturas, assim que, de repente, se eu não trabalhasse, eu não teria. Eu acho que o trabalho me ensinou muita coisa, até na parte de buscar ser uma pessoa mais decidida, uma pessoa que busca ideais e tudo mais. Eu acho que o trabalho me ajuda muito na tomada de decisões, porque você acaba assumindo determinada postura do teu lado pessoal. Também é importante você se manter, vamos colocar assim, você tem uma personalidade do lado pessoal, manter aquela personalidade, entendeu? Eu acho que é importante. (Entrevistado 01).

Tabela 38 - Distribuição dos respondentes da pesquisa por resposta à pergunta "Você acha que o trabalho afeta na definição de quem é você?"- dados coletados nas agências bancárias de julho a outubro de 2007

\begin{tabular}{l|c|c}
\hline Categorias & Quantidade & Freqüência \\
\hline Sim & 48 & $96 \%$ \\
Não & 02 & $04 \%$ \\
\hline Total & $\mathbf{5 0}$ & $\mathbf{1 0 0} \%$ \\
\hline \hline
\end{tabular}

Fonte: Dados de pesquisa

Ao se analisar de forma cruzada a identificação com o trabalho e o fato de o trabalho definir quem ele é, observa-se que 45 entrevistados expressaram respostas afirmativas para as duas questões. Nenhum entrevistado deu dupla resposta negativa para as questões.

Quadro 8 - Quadro de análise da expressão da Identidade associada ao trabalho

\begin{tabular}{|c|c|c|}
\hline \multirow{2}{*}{ Identifica com o trabalho } & \multicolumn{2}{|c|}{ O trabalho afeta na definição de quem ele é } \\
\hline $\boldsymbol{\nabla}$ & Sim & Não \\
& $\boldsymbol{\nabla}$ & $\boldsymbol{\nabla}$ \\
\hline Sim & 45 & 0 \\
\hline Não & 3 & 0 \\
\hline
\end{tabular}

Fonte: o autor

Avaliando as respostas sobre o que eles gostariam de mudar em seus trabalhos, 18 entrevistados propuseram sugestões que podem ser configuradas como "A forma de gestão da empresa" e 16 descreveram melhorias sobre "O processo de trabalho" (Vide Tabela 39).

Um detalhe interessante é que o entrevistado que afirmou que "mudaria de trabalho" acredita que o trabalho afeta na definição de quem ele é, entretanto, não se identifica com ele. $\mathrm{O}$ entrevistado se vale de uma concepção moral para explicar como o trabalho o define e, mesmo fazendo algo com o qual não se identifica, entende a importância da atividade em termos de responsabilidade social.

Eu não consigo me imaginar parada, não nasci para ser dondoca. Sabe aquela coisa de ficar: ah! O que é que eu vou fazer. Eu não consigo ficar parada, eu não sou workaholic, não sou. Mas o trabalho é bem aquela coisa do Lutero: o trabalho dignifica o homem. Eu 
acho que a gente é digno por fazer alguma coisa em prol de alguém, e só fazer essa uma coisa já é trabalho para mim. Então não sei, para mim trabalho, ele é tudo porque através dele que eu tiro o sustento da minha família. Se (o nome do marido) não trabalhasse também? A gente precisa do nosso trabalho para sobreviver, o trabalho faz a gente se sentir completo, dia após dia. (O trabalho) faz a gente crescer como pessoa assim..., aquela responsabilidade de estar ali a serviço. Ele te gera internamente uma sensação de responsabilidade que te move, ela que te faz levantar todo dia. Não é como responsabilidade do ponto negativo não, é a responsabilidade de você ser importante naquilo que você faz, da tua presença ali ser importante. (Entrevistado 15).

Outro entrevistado exemplificou-se como extremamente afetado pelo trabalho, tanto em termos da identificação quanto de quem ele é.

Eu não vou em casa almoçar, e eu devo isso ao (nome do banco). De uma época, onde eu me dispus a trabalhar um pouco mais, e eu esticava o meu horário de almoço de onze para meio dia. Depois de meio dia eu não consegui sair às uma, de uma para duas, de duas para marmita, até que eu cancelei a marmita, e hoje eu me adeqüei a essa situação. Eu não sinto fome, eu não tenho úlcera, eu até me examino pra ver se essa é uma situação normal, as pessoas me criticam, mas isso é o meu dia-a-dia. (Entrevistado 47).

Tabela 39 - Distribuição dos respondentes da pesquisa por resposta à pergunta "O que gostaria de mudar em seu trabalho?"- dados coletados nas agências bancárias de julho a outubro de 2007

\begin{tabular}{l|c|c}
\hline \hline Categorias & Quantidade & Freqüência \\
\hline A forma de gestão da empresa & 18 & $36 \%$ \\
O processo de trabalho & 16 & $32 \%$ \\
Não mudaria nada & 05 & $10 \%$ \\
As pessoas & 04 & $08 \%$ \\
Recursos disponíveis & 03 & $06 \%$ \\
Gostaria de mudar o seu próprio jeito de ser & 02 & $04 \%$ \\
O contexto bancário & 01 & $02 \%$ \\
Mudaria de trabalho & 01 & $02 \%$ \\
\hline Total & $\mathbf{5 0}$ & $\mathbf{1 0 0} \%$ \\
\hline \hline
\end{tabular}

Fonte: Dados de pesquisa

\subsubsection{Expressão da Identidade, identificação e categoria profissional}

Em termos da categoria profissional, 37 bancários afirmam que se identificam com ela (Vide Tabela 40). Outros 13 afirmam que não se identificam com a categoria. A não identificação com a categoria foi principalmente associada à forma como acontecem as manifestações sindicais. Mesmo entre os que se identificam com a categoria, houve entrevistados que a descrevem como desunida. 
Tabela 40 - Distribuição dos respondentes da pesquisa por resposta à pergunta "Você se identifica com a categoria profissional dos bancários?"- dados coletados nas agências bancárias de julho a outubro de 2007

\begin{tabular}{l|c|c}
\hline \hline Categorias & Quantidade & Freqüência \\
\hline Sim & 37 & $74 \%$ \\
Não & 13 & $26 \%$ \\
\hline Total & $\mathbf{5 0}$ & $\mathbf{1 0 0} \%$ \\
\hline \hline
\end{tabular}

Fonte: Dados de pesquisa

Quando questionados se sentiam bancários, quase a totalidade dos entrevistados afirmou que sim, com 42 respostas (Vide Tabela 41). A associação com a categoria foi mais citada do que quando foram questionados sobre a identificação com ela.

Tabela 41 - Distribuição dos respondentes da pesquisa por resposta à pergunta "Você se sente bancário?" - dados coletados nas agências bancárias de julho a outubro de 2007

\begin{tabular}{l|c|c}
\hline Categorias & Quantidade & Freqüência \\
\hline Sim & 42 & $84 \%$ \\
Não & 08 & $16 \%$ \\
\hline Total & $\mathbf{5 0}$ & $\mathbf{1 0 0} \%$ \\
\hline \hline
\end{tabular}

Fonte: Dados de pesquisa

Analisando as questões sobre a identificação com a categoria e se sentir bancário, percebe-se que 33 respondentes se identificam e se sentem bancários (Quadro 9). Os que se sentem bancários, mas não se identificam com a categoria ( 9 entrevistados) afirmam que o sindicato não os representa, sentem que os bancários não são unidos ou querem se diferenciar da maioria dos bancários.

A gente vai faz a carteirinha desconta um valor pequeno da gente por mês, mas é só no caso de você sair da empresa mesmo, que você tem o advogado para estar assinando, porque eu acho que o sindicato nosso, o que ele faz pra gente é praticamente nada, é um cabidão de emprego mesmo, para quem queria se afastar da empresa que foi lá ficar enroscado no sindicato. (Entrevistado 02).

[...] porque eu vejo muito... eu vejo muita gente assim, sabe, sem boa vontade para poder... eu não identifico (com a categoria profissional), então me considero bancário, sou bancário, mas eu acho que assim eu... eu procuro cada vez mais diferenciar meu serviço. (Entrevistado 03).

Eu falo que a gente é desunido, mas, eu mesmo... tem uma reunião, eu acabo não indo. [...] Mas acho que não une mesmo, não vai. Quando tem uma manifestação aqui é meia dúzia. Eu acho que a gente é assim, meio disperso mesmo. Devia ter um pouquinho mais de união, trocar mais informações, sabe. Acho que isso num... acho que falta isso mesmo. É estranho mesmo, você trabalha numa cidade que não é tão grande e você às vezes não conhece um companheiro que trabalha ali num banco ao lado [...] (Entrevistado 07).

Quatro entrevistados não se sentem bancários, mas se identificam com a categoria. Dois destes entrevistados possuem outra atividade profissional, concomitantemente. Outros quatro 
respondentes não se identificam e não se sentem bancários. Interessante relatar que nos comentários finais da pesquisa, dois destes bancários confessaram abertamente o desejo de abandonar imediatamente a profissão, sendo que um deles concretizou tal vontade um mês depois da entrevista e o outro começou a constituir uma profissão paralela. Embora um entrevistado se sinta bancário e se identifique com a categoria, ele descreve que o bancário não sabe ser outra coisa e o trabalho do banco como algo não palpável.

Eu ouvi uma vez de um colega aqui, ele falou assim... já até saiu do banco - a pessoa que é bancária, o bancário, ele só sabe ser bancário, ele não sabe... a pessoa que trabalha numa indústria... o administrador que trabalha em banco ele só sabe ser bancário, a pessoa que trabalha numa indústria, ele tem uma visão maior do mercado, porque indústria, você pode trabalhar numa indústria metalúrgica, uma indústria de confecção, ele... é administração industrial. Então, às vezes, como é que eu vou explicar, o bancário só faz isso, mas o quê que o bancário faz?[...] Olha, aqui a gente não tem nada palpável. Eu acho que o banco ele não produz. Ele não gera produção de bens. (Entrevistado 04).

Outro bancário relata a condição efêmera de ser bancário relacionada ao contexto atual de transformações.

Só que o bancário hoje em dia, ele não é bancário, ele está bancário, porque a gente nunca sabe o dia de amanhã, por melhor que você vai empenhando o seu papel sempre pode acontecer de haver cortes. [...] Então a gente está nessa, a gente nunca sabe o dia de amanhã o quê que é ser bancário. Antigamente, quando eu entrei no banco, eu tinha dezesseis anos, bancário era... você falava: "Eu sou bancário” você estava com a vida feita e se for ver é um período curto dez anos... Então a gente nunca sabe o dia de amanhã. Eu, no momento, eu estou satisfeito com a profissão, só que eu não almejo isso para o resto da minha vida, eu pretendo formar... deixa eu ver se o chefe não está olhando... - formar e procurar uma outra coisa. (Entrevistado 02).

\section{Quadro 9 - Quadro de análise da expressão da Identidade associada à categoria profissional}

\begin{tabular}{|c|c|c||}
\hline & \multicolumn{2}{|c|}{ Se sente bancário } \\
\hline Identifica com a categoria & Sim & Não \\
& $\boldsymbol{\nabla}$ & $\boldsymbol{\nabla}$ \\
\hline Sim & 33 & 4 \\
\hline Não & 9 & 4 \\
\hline
\end{tabular}

Fonte: o autor

\subsubsection{Expressão da Identidade, identificação e organização}

A grande maioria dos bancários que participaram da pesquisa (44 respondentes) estabelece uma relação de identificação com a organização em detrimento à condição de ser bancário. Ou seja, preferem ser da organização em outra profissão a continuar sendo bancário em outra instituição. Tais informações reforçam a idéia de que a organização estabelece a referência 
para o indivíduo mais presente do que o trabalho em si ou a categoria profissional (Vide Tabela 42). Um dos entrevistados afirma que prefere a organização e que, se sair dela, não volta para este setor, ou seja, procura outro tipo de emprego. $\mathrm{O}$ entrevistado relata ainda o fato de que há bancários que "pulam" de banco em banco.

Prefiro trabalhar no banco em outra função. Eu, se eu sair do banco hoje, eu não procuro serviço em outro banco, eu não me vejo em outro banco. Talvez porque eu falo assim: "Deu o que tinha que dar", porque banco para mim é tudo igual. Talvez um tenha mais um pouco de pressão, o outro menos pressão, mas a instituição, o sistema é o mesmo, o que muda é o tratamento, o funcionário, o cliente. Isso aí, acho que não... é a cara do banco é o relacionamento com o cliente, mas eu me vejo dentro do banco na outra profissão, na mesma profissão em outro banco não, como às vezes que têm essas pessoas, que pulam, pulam, pulam... (Entrevistado 08).

Três funcionários preferem continuar sendo bancários em outra instituição e três expressam que depende da função no banco. Os que preferem continuar como bancários não deram motivos específicos e os que afirmaram depende da função, associaram a questões financeiras e ao tipo de tarefa a ser executada.

Tabela 42 - Distribuição dos respondentes da pesquisa por resposta à pergunta "Entre trabalhar como bancário em outra organização (diferente da que trabalha atualmente) e trabalhar no banco em outra profissão (não sendo bancário), em qual situação você se identifica mais?"- dados coletados nas agências bancárias de julho a outubro de 2007

\begin{tabular}{l|c|c}
\hline \hline Categorias & Quantidade & Freqüência \\
\hline Continuar na organização em outra profissão & 44 & $88 \%$ \\
Continuar sendo bancário em outra organização & 03 & $06 \%$ \\
Depende da função a ser desempenhada & 03 & $06 \%$ \\
\hline Total & $\mathbf{5 0}$ & $\mathbf{1 0 0} \%$ \\
\hline \hline
\end{tabular}

Fonte: Dados de pesquisa

Para 40 entrevistados a organização afeta na definição de quem ele é, sendo que dez acreditam que não (Vide Tabela 43). Para os que relatam que o banco define quem ele é, as justificativas são diversificadas. Para alguns, o discurso ou a política de responsabilidade social da instituição afetou diretamente o seu ser.

Mudou porque assim eu sempre fui uma pessoa muito preocupada com qualidade de vida de meus funcionários, e eu procurava fazer muito fazer isso em outros bancos. Só que não era preocupação desses bancos, e eu não via essa preocupação, como eu vejo aqui no (Nome do banco). $O$ (Nome do banco) realmente está muito preocupado, então está muito eh... alinhado com o meu pensamento. (Entrevistado 12).

Outro afirma que o banco define seus diversos "seres".

Eu acho que ela define quem são os (Nome do entrevistado no plural). Eu acho que ela tem uns patamares, quer dizer, os (Nome do entrevistado no plural) hoje para (o Nome 
do banco), para mim, são aqueles que estão entrando, que estão começando a ter uma base de aprendizagem. (Entrevistado 34).

Há os que afirmam que são comportamentalmente diferentes, como duas identidades em paralelo.

Eu costumo dizer que (no Nome do Banco) eu sou muito mais, vamos dizer assim, expansivo do que na minha vida privada, acho que final de semana, você... às vezes você está cansado de falar tanto que você se reserva um momento de silêncio, um momento de mais calma, mas no trabalho não tem esse... (Entrevistado 37).

Se o bancário não for quem o banco quer que ele seja, deixa de ser bancário.

O banco estabelece aquilo que eu devo fazer. Ele já tem uma função pré-definida, no caso de agente de atendimento, eu tenho que ter certos requisitos, eu tenho que me enquadrar, se eu não me enquadrar nele, estou fora, outra pessoa vem e ocupa, então o banco define sim quem ele quer que eu seja. (Entrevistado 43).

Os entrevistados que responderam que o banco não os define descrevem diversos elementos para justificar a resposta. Um dos entrevistados explica que o banco não é a única opção para sua vida.

Eu acho que muitas coisas na minha vida eu consegui, ou eu deixei de conseguir através do banco, mas o banco não é a minha vida. Eu acho que se amanhã eu sou demitido, não sei se talvez a pergunta chega por esse lado, mas se amanhã eu for demitido, eu não vou ficar morrendo, falar assim: "Não, o banco era a única coisa que eu sabia fazer, porque o banco é a minha vida". Gosto do que eu faço, procuro fazer o melhor de mim, mas se não deu certo, é porque ao meu redor não quiseram, vamos dizer assim, eu faço o que posso e o que não posso, mas se não deu certo é porque não dependeu de mim mais. (Entrevistado 08).

Outro entrevistado expressa que foi preciso entrar em um confronto com a organização para manter seu ponto de vista e, por isso, a organização não conseguiu moldá-lo.

Eu já tive atrito até com (o Nome do banco), por eu defender, não interesses meus, mas interesses que eu julgava correto. Então, (o Nome do banco) não me moldou, por isso que eu tenho vários atritos e eu acho que se eu pudesse, eu não seria um bancário hoje, eu não trabalharia (no Nome do Banco), justamente por causa disso, porque eu entrei em atrito com algumas coisas (do Nome do Banco), e por ninguém me apresentar uma razão de eu estar errado, não tem como uma pessoa falar que eu estou errado, porque eu procuro... A consciência minha que me leva. Eu acredito que (o Nome do Banco) não conseguiu moldar. Seria até bom se ela conseguisse me melhorar, mas se eu aceitar tudo o que (o Nome do Banco) impõe ou faz, eu estaria pior, a gente também. (Entrevistado 25). 
Tabela 43 - Distribuição dos respondentes da pesquisa por resposta à pergunta "O banco afeta na definição de quem você é?" - dados coletados nas agências bancárias de julho a outubro de 2007

\begin{tabular}{l|c|c}
\hline \hline Categorias & Quantidade & Freqüência \\
\hline Sim & 40 & $80 \%$ \\
Não & 10 & $20 \%$ \\
\hline Total & $\mathbf{5 0}$ & $\mathbf{1 0 0} \%$ \\
\hline \hline
\end{tabular}

Fonte: Dados de pesquisa

Analisando-se as questões de forma conjunta, observa-se que dentre os 50 entrevistados, 36 se posicionam como permanecendo na organização, sendo que a organização afeta na definição de quem ele é. Oito entrevistados priorizam a organização, mas não acham que ela afeta na definição de quem ele é (Vide Quadro 10).

Quadro 10 - Quadro de análise da expressão da Identidade associada à organização

\begin{tabular}{|r|c|c|}
\hline \multirow{2}{*}{ Ser bancário X Ser da organização } & \multicolumn{2}{|c|}{ O banco afeta na definição de quem ele é } \\
\hline $\boldsymbol{\nabla}$ & Sim & Não \\
\hline Bancário & 2 & 1 \\
\hline Organização & 36 & 8 \\
\hline Depende da função & 2 & 1 \\
\hline
\end{tabular}

Fonte: o autor

Observa-se que a maioria dos entrevistados, ao descreverem os elementos de identificação com a organização, delineiam questões associadas à visão de importância social e gestão responsável por parte da empresa. Dentre os 50 participantes da pesquisa, 30 citam que o "Discurso/política de responsabilidade social", a "Função social da empresa" e a "Política de relacionamento responsável com o cliente que a empresa adota" são os elementos de identificação. Isso mostra que a identificação está acontecendo com a imagem positiva que a organização quer transparecer (Vide Tabela 44).

Tabela 44 - Distribuição dos respondentes da pesquisa por resposta à pergunta "Com quais aspectos da organização você se identifica?"- dados coletados nas agências bancárias de julho a outubro de 2007

\begin{tabular}{l|c|c}
\hline \hline Categorias & Quantidade & Freqüência \\
\hline Discurso/ política de responsabilidade social & 14 & $28 \%$ \\
Função social da empresa & 10 & $20 \%$ \\
Políticas e práticas de Gestão de Pessoas que a empresa adota & 10 & $20 \%$ \\
Características e elementos associados à execução do trabalho & 10 & $20 \%$ \\
Política de relacionamento responsável com o cliente que a empresa & 06 & $12 \%$ \\
adota & & $\mathbf{5 0}$ \\
\hline Total & $\mathbf{1 0 0} \%$ \\
\hline
\end{tabular}

Fonte: Dados de pesquisa

A Tabela 45 mostra que, para 29 entrevistados, a organização possui uma importância 
econômica, entendendo-a como uma fonte de obter salários e benefícios.

$O$ (nome do banco), hoje, foi tudo para mim, porque graças a ele eu consegui terminar a minha faculdade, e me manter financeiramente, ter a minha casa, ter o meu carro. Essa parte que a gente geralmente coloca como um sonho na vida da pessoa, conquista de alguma coisa, graças ao (nome do banco), eu consegui. Então, eu vejo que basicamente tudo para mim [...] (Entrevistado 01).

Os 16 entrevistados que descrevem o banco na perspectiva da importância pessoal, afirmam que ele permite crescer e aprender coisas novas.

Bom, o banco tem muita importância na minha vida, porque eu aprendi muito com o banco. Eu viajei muito, eu tive oportunidade de conhecer muitas pessoas, muitos lugares, muitas cidades, oportunidade de ser transferido para cinco ou seis cidades. (Entrevistado 12).

Muita importância, primeiro porque você lidando com as pessoas, você aprende muito e a gente, você vê situações no dia a dia que te ensinam, que te mostram, muitas vezes ali na frente. Você vai ter mais facilidade de tomar uma determina decisão em função de tudo que a gente aprende aqui. (Entrevistado 22).

Outros quatro descrevem como importância profissional, o primeiro emprego que conseguiu.

(Nome do banco) foi um primeiro emprego, é o meu único emprego. Foi uma oportunidade que apareceu na minha vida, quando eu acabei de formar. (Entrevistado $44)$.

Ele tem uma grande importância, nele que eu estou conseguindo me realizar profissionalmente, estou conseguindo meu desenvolvimento pessoal. E então ele está tendo uma grande participação assim na minha vida atualmente. (Entrevistado 45).

Como importância social, o entrevistado descreve a função que o banco tem em termos sociais, sente que faz parte de uma coisa que tem relevância social.

Eu não sabia que ela era do tamanho que ela é não, é um absurdo a quantidade de contas abertas, a quantidade de pontos de venda atendendo, a quantidade de beneficios sociais que ela promove é uma coisa fantástica. (Entrevistado 34).

Tabela 45 - Distribuição dos respondentes da pesquisa por resposta à pergunta "Qual é a importância que a organização tem na sua vida?"- dados coletados nas agências bancárias de julho a outubro de 2007

\begin{tabular}{l|c|c}
\hline \hline Categorias & Quantidade & Freqüiência \\
\hline Importância em aspectos econômicos & 29 & $58 \%$ \\
Importância em aspectos pessoais & 16 & $32 \%$ \\
Importância em aspectos profissionais & 04 & $08 \%$ \\
Importância em aspectos sociais & 01 & $02 \%$ \\
\hline Total & $\mathbf{5 0}$ & $\mathbf{1 0 0} \%$ \\
\hline
\end{tabular}

Fonte: Dados de pesquisa 


\subsubsection{Expressão da Identidade, identificação e consumo}

No que tange às questões associadas ao consumo, dentre os entrevistados, 40 bancários afirmaram que gostam de realizar compras e 10 não gostam (Vide Tabela 46). Ao descrever as compras, alguns descrevem como forma de compensação.

É prazeroso. Quando você sai do banco para dar uma relaxada, você vai ali na loja compra uma calça, uma blusa e um sapato... ah, é muito gostoso. (Entrevistado 09).

[...] parece que você é recompensado de alguma forma por, vamos supor assim, um dia de trabalho, alguma coisa assim, você passou apertado, você vai lá compra alguma coisinha... (Entrevistado 13).

Comprar é a contrapartida do trabalho, uma forma de recompensar pelo esforço, pela dedicação ao serviço, pelo estresse dos dias de trabalho.

Eu sinto que é uma realização de transformar o meu trabalho em algo concreto, que dizer eu, no meu caso da compra, é uma compra específica para deixar a família com um conforto e bonito. (Entrevistado 14).

Eu acho que é retorno do teu trabalho. Tem assim, antes, quando eu era solteira, era mais, agora a gente controla mais, mas assim, quando eu era solteira, eu falava que a recompensa do trabalho, daquela dedicação é você poder sair e comprar. Tinha dia que estava muito estressada com o trabalho, deixa eu ir comprar alguma coisa, para me satisfazer, para ter um retorno do que a gente fica batalhando. (Entrevistado 36).

Tabela 46 Distribuição dos respondentes da pesquisa por resposta à pergunta "Gosta de fazer compras?" - dados coletados nas agências bancárias de julho a outubro de 2007

\begin{tabular}{l|c|c}
\hline Categorias & Quantidade & Freqüência \\
\hline Sim & 40 & $80 \%$ \\
Não & 10 & $20 \%$ \\
\hline Total & $\mathbf{5 0}$ & $\mathbf{1 0 0} \%$ \\
\hline \hline
\end{tabular}

Fonte: Dados de pesquisa

Depois de analisar os discursos dos entrevistados, foram separadas as respostas sobre sua opinião como consumidores e sua relação com o consumo. Organizou-se as falas em três classificações:

- Consumistas: nesta classificação foram colocados os entrevistados que se declararam expressamente como consumistas ou que manifestaram opiniões no sentido de que “adoram fazer compras", “é um prazer comprar", "gosto de gastar em compras" dentre outras expressões similares.

- Moderados: aqueles que compram, mas sempre expressam como controlados, planejando. Não mostraram entusiasmo ao responder sobre o assunto. 
- Não consumistas: aqueles que declaram expressamente que não gostam de comprar.

Ressalta-se que esta classificação é apenas convencional, uma forma de interpretação das respostas, não tendo a pretensão de ser uma definição precisa de tais conceitos ${ }^{13}$.

Mais da metade dos entrevistados (28 respondentes) definiram ou se descreveram como consumistas. Outros 17 expressam que são consumidores moderados. Cinco afirmam que consomem pouco ou se declaram não consumistas (Vide Tabela 47). Os entrevistados sempre se expressam de forma muito eufórica ao se descreverem como consumistas.

Eu sou muito consumista! (Entrevistado 07).

Ah, é um prazer muito grande. Comprar... um prazer, uma coisa assim, sem explicação, às vezes eu estou triste, aí saio, compro, compro, compro, fico alegre. Depois posso até ficar triste, porque eu vi o que gastei. Às vezes, eu comprei alguma coisa que eu não vou usar, mas é um prazer enorme, uma sensação muito boa, comprar! (Entrevistado 24).

Eu sofro um consumismo danado, muito prazer, sem medo de errar! (Entrevistado 27).

Eu sinto um prazer de estar fazendo aquela "compração", e fazer uma boa compra, existe um prazer nessa busca, e nesse atender a necessidade! (Entrevistado 34).

Ah, prazer, eu adoro, eu gosto, eu sinto realizado! (Entrevistado 35).

Os consumidores moderados são aqueles que se descrevem como pessoas que compram, mas sempre de forma planejada e controlada.

Gosto de comprar, mas eu evito, quando eu vou comprar alguma coisa já tenho em mente o que eu quero, e onde vou achar. (Entrevistado 08).

Ah, gostar até gosto, mas ultimamente tenho sido assim mais centrado, porque para dar uma organizada nas contas, e depois, eu acho que a gente vive com muito apelo, então se você for sair para comprar, é uma beleza, mas... (Entrevistado 37).

Ser consumidor é você dentro do seu potencial, que você tem, que a gente tem três tipos ou até mais de consumidores, ter potencial dentro daquilo que ele pode fazer e que ele não seja um consumidor abusivo, porque isso vai trazer problemas para ele mesmo. (Entrevistado 26).

\footnotetext{
${ }^{13}$ Uma outra convenção possível para a mesma classificação poderia ser os "eufóricos", os "retidos" e os "sem entusiasmo".
} 
Os não consumistas não gostam de participar do ato de comprar ou de gastar dinheiro.

Descrevem as compras com poucas frases e pouco entusiasmo sobre o assunto.

Tabela 47 Distribuição dos respondentes da pesquisa por como se definem na forma como consomem - dados coletados nas agências bancárias de julho a outubro de 2007

\begin{tabular}{l|c|c}
\hline Categorias & Quantidade & Freqüência \\
\hline Como pessoas que consomem muito ou como consumistas & 28 & $56 \%$ \\
Consumidores moderados & 17 & $34 \%$ \\
Não consumistas ou que consomem pouco & 05 & $10 \%$ \\
\hline Total & $\mathbf{5 0}$ & $\mathbf{1 0 0} \%$ \\
\hline \hline
\end{tabular}

Fonte: Dados de pesquisa

A grande maioria, 44 entrevistados, acha que consegue expressar sua individualidade ao consumir. Os seis restantes afirmam que não (Vide Tabela 48). Os que acreditam que podem expressar sua individualidade por meio do consumo valem-se do argumento "conhecer quem consome pelo jeito que consome". Neste sentido, utilizam o critério para analisar o outro e para analisar a si mesmos.

A gente conhece pessoas pelo consumo. O consumo move as pessoas das casas delas para outros ambientes e move as pessoas em pensamento também. Porque existem hoje os consumidores que usam a Internet, que são pessoas que não saem de casa para manter suas relações de troca, mas eu acredito que o consumo ele seja alguma diretriz... ele inicia movimento e, de repente, toma um impulso. Um movimento que é um movimento humano, que é um movimento financeiro, mas que é um movimento, que está ali. (Entrevistado 15).

Infelizmente, a ostentação de carros, celulares, tecnologia em geral transmite muito quem você é. Pessoas, por exemplo, que gostam de carros pequenos, eu entendo que as pessoas, são pessoas que pensam muito pequeno, são pessoas que não têm anseios, que não querem crescer, não querem uma evolução, eu vejo dessa forma. A simplicidade também, ela não faz bem para a pessoa. A simplicidade exagerada, eu acho que ela não faz bem para a pessoa. Eu acho que tudo tem o seu bom senso. Você não pode... não precisa nem estar lá e nem cá. Um pouco de ostentação também não faz mal para ninguém. Faz bem, faz bem para você, porque você trabalhou, você acordou cedo, você madrugou para estudar, faz bem. (Entrevistado 05).

(... ) quando você olha na pessoa que você vê o sapato, você já sabe mais ou menos o tipo de sapato que ela usa, mais ou menos o perfil dessa pessoa. (Entrevistado 12).

Alguns manifestam que procuram mostrar sua personalidade por meio do que consomem, como forma de mostrar quem é.

[...] as coisas diferentes que eu busco comprar, coisas diferentes para mostrar minha personalidade. (Entrevistado 13).

Outros expressam que consomem as coisas com as quais estabelecem uma relação de identificação. 
Acho que você pode ir em uma prateleira, que tem vários produtos, geralmente, você vai nos produtos que mais te identificam. Se você for numa loja comprar uma roupa, você vai comprar geralmente uma roupa que você mais se identifica com ela. (Entrevistado 26).

Cada um procura consumir aquilo que ele é. Se a pessoa é uma pessoa exibicionista, ela vai querer comprar um carro maravilhoso, independente dela poder ou não. Tem gente que deixa até de comer e faz trezentas prestações para poder aparecer com aquele carro. Eu acho que sim, essa forma de como a pessoa consome mostra um pouco da forma como ela é. (Entrevistado 33).

Apenas um entrevistado explicou o porquê não expressa sua individualidade por meio do consumo.

[...] Acho que, a gente tem que expressar a individualidade de outras maneira, com atitudes, com pensamentos, com personalidades. (Entrevistado 04).

Tabela 48 Distribuição dos respondentes da pesquisa por resposta à pergunta "Você acha que ao consumir consegue expressar a sua individualidade, mostrando um quem é a partir do que consome e da forma que consome?" - dados coletados nas agências bancárias de julho a outubro de 2007

\begin{tabular}{l|c|c}
\hline Categorias & Quantidade & Freqüência \\
\hline Sim & 44 & $88 \%$ \\
Não & 06 & $12 \%$ \\
\hline Total & $\mathbf{5 0}$ & $\mathbf{1 0 0} \%$ \\
\hline \hline
\end{tabular}

Fonte: Dados de pesquisa

Entre os entrevistados, 42 acreditam que o consumo afeta na definição de quem ele é, sendo que os oito restantes afirmam que não. Os que afirmam que sim descrevem essa relação de diversas formas. Alguns colocam aspectos externos como aparência.

Sim, a pessoa, o consumo define muito a pessoa. Você vê, seja o tipo de vestir, o tipo de alimentação, o tipo é de... tudo. Acho que tudo define a pessoa, acho que você vai consumir aquilo que você... as tendências. (Entrevistado 23).

Outros colocam aspectos internos como sentimentos de infelicidade ou felicidade.

Eu acho que define. Eu acho que eu sou um pouco depressiva, então, quando eu estou depressiva é quando eu compro. Se eu estou mais triste, é quando eu compro, eu gasto. Quando, eu estou normal, ai eu gasto menos. Só que é assim também, eu estive uma fase dificil na minha vida, que é quando (o Nome do filho) foi embora, depois (o Nome do Marido) foi embora. Trabalhou fora, depois quando (o Nome do outro filho) foi embora. Então nessas fases assim, que eu fico pior. (Entrevistado 24).

Eu também defino os meus modos, meus costumes, define a personalidade, define as características do ser humano $e$ do (o Próprio nome do entrevistado) especificamente.(Entrevistado 27).

Um entrevistado acredita que a escolha do que consumir mostra a sua consciência ou responsabilidade social. 
Acaba definindo sim, porque se eu posso consumir alguma coisa que é produzida é... com responsabilidade, sem agredir o meio ambiente, sem ter é... tendo trabalho infantil, uma série de coisas, eu me sinto melhor do que se eu comprasse algum produto que tivesse essa política incorreta. (Entrevistado 31).

Dentre os que afirmam que sim, um ponderou essa definição, mostrando que há outros elementos que definem mais.

Menos do que meu trabalho, vamos dizer assim, mas também tem o seu peso aí na minha definição, vamos dizer assim. (Entrevistado 22).

Os que afirmam que não, alguns afirmam que não são "levados" pelos modismos.

Eu não me deixo levar pelas ondas. Como que eu vou falar... Têm as manias que estão no momento. Eu não me deixo levar por isso, porque, senão, você sempre vai estar consumindo, sempre tem uma nova moda. Então, eu procuro consumir o que eu preciso, o quê eu quero. (Entrevistado 08).

Um expressou que o consumo não o define. Ele é quem define o consumo.

Não, acho que não. Eu acho que o (Nome do Entrevistado) define um pouco o consumo, o contrário.(Entrevistado 34).

Tabela 49 Distribuição dos respondentes da pesquisa por resposta à pergunta "Você acha que o consumo afeta na definição de quem é você?"- dados coletados nas agências bancárias de julho a outubro de 2007

\begin{tabular}{l|c|c}
\hline Categorias & Quantidade & Freqüência \\
\hline Sim & 42 & $84 \%$ \\
Não & 08 & $16 \%$ \\
\hline Total & $\mathbf{5 0}$ & $\mathbf{1 0 0} \%$ \\
\hline \hline
\end{tabular}

Fonte: Dados de pesquisa

Analisando de forma conjunta os dados, como exposto no Quadro 11, percebe-se que 37 entrevistados respondem simultaneamente que expressam sua individualidade por meio do consumo e o consumo define quem ele é. Dentre os que acreditam que o consumo os define, 23 se expressaram como consumistas. Dos que se definem ou se expressam como consumistas, 24 acreditam que expressam sua individualidade por meio do consumo.

Um entrevistado deu dupla resposta negativa para a questão sobre o consumo o definir e expressar sua individualidade. Outro entrevistado, afirmou que o consumo não afeta na definição de quem ele é e não expressa sua individualidade.

As duplas respostas mostram os extremos da forma como os indivíduos se posicionam no aspecto do consumo e nas visões que têm de si mesmos. Entretanto, a realidade nem sempre assume valores extremos. É nessa riqueza de possibilidades que a Identidade se concretiza nos 
diversos indivíduos, mostrando pontos comuns e singularidades.

\section{Quadro 11 - Quadro de análise da expressão da Identidade associada ao consumo}

\begin{tabular}{|c|c|c|c|c|c|}
\hline \multirow{2}{*}{$\begin{array}{c}\begin{array}{c}\text { Expressa sua } \\
\text { individualidade }\end{array} \\
\boldsymbol{\nabla}\end{array}$} & \multicolumn{2}{|c|}{$\begin{array}{c}\text { O consumo afeta na definição de } \\
\text { quem ele é }\end{array}$} & \multicolumn{3}{|c|}{$\begin{array}{c}\text { Como se define } \\
\nabla\end{array}$} \\
\hline & Sim & Não & $\underset{\nabla}{\text { Consumista }}$ & Moderado & Não consumista \\
\hline $\operatorname{Sim}>$ & 37 & 7 & 24 & 15 & 5 \\
\hline Não \ & 5 & 1 & 4 & 2 & 0 \\
\hline $\begin{array}{c}\text { Como se define } \\
\nabla\end{array}$ & $\nabla$ & $\nabla$ & & & \\
\hline Consumista & 23 & 5 & & & \\
\hline Moderado & 15 & 2 & & & \\
\hline Não consumista & 4 & 1 & & & \\
\hline
\end{tabular}

Fonte: Dados de pesquisa

4.6.5. Expressão da Identidade, identificação e consumidor

Para 37 entrevistados, indivíduo consumidor afeta na definição de quem ele é. Os outros 13 entrevistados acreditam que os consumidores não definem quem são. A Tabela 50 expõe os dados desta questão. Em geral, os entrevistados manifestaram que se sentem diferentes por causa dos consumidores, mas não sabem ou têm dificuldades para definir o porquê. Alguns descrevem os outros consumidores, fora do banco, como afetando a definição de quem são, tanto como consumidores (eu-consumidor) quanto como trabalhadores (eu-trabalhador).

Eu acho que afeta sim porque, eu acho, não tenho certeza, que eu sou uma pessoa que, como eu falei, sou controlada. Então a visão que as pessoas vão ter como consumidoras de mim, que eu sou uma pessoa mais tranqüila, controlada e tudo mais, se eu fosse uma pessoa compulsiva, eles teriam uma outra visão, então eu acho que afeta e muito. (Entrevistado 01).

Acaba definindo. Não tinha pensado nisso não, mas acaba definindo, porque de uma certa maneira qualquer consumo acaba nos influenciando. Porque se uma pessoa consome alguma coisa e aquilo ali pode despertar um desejo em mim também de consumir, eu acabo sendo influenciado. Quem me disse que eu precisava ter um carro? (Entrevistado 31).

Outros descrevem os consumidores a quem prestam seu serviço como definidores, tanto para como ser quanto como não ser.

Talvez sirva como espelho. Alguns deles servem para mostrar o que eu não devo ser. Alguns deles devem mostrar como eu devo seguir aqueles passos deles. Eu acho que define sim. Eu acho é essencial o consumidor como espelho. (Entrevistado 08).

Acho que sim. Acho que define sim, porque você acaba querendo satisfazer da melhor 
forma possivel e, querendo ou não, você acaba satisfazendo mais as vontades dele que as suas vontades. Que nem, dentro do banco, você tenta, da melhor forma possivel, atendêlo com rapidez, com aquilo que ele quer, com o objetivo que ele quer, acho que mais ou menos isso, acho que sim. (Entrevistado 28).

Os que afirmam que não, se expressaram muito pouco sobre o assunto. Entretanto, um entrevistado que expressa que não acredita que o consumidor possa defini-lo, afirma que aprende na relação com ele.

Talvez ele me traga algumas referências, conforme eu te disse, por exemplo, quando eu tenho conhecimento de pessoas que consumiram ou que adquiriram coisas além do que podiam. Assim você tem um exemplo daquilo que você não pode fazer. (Entrevistado 37).

Tabela 50 - Distribuição dos respondentes da pesquisa por resposta à pergunta "Você acha que o consumidor afeta na definição de quem é você?"- dados coletados nas agências bancárias de julho a outubro de 2007

\begin{tabular}{l|c|c}
\hline \hline Categorias & Quantidade & Freqüência \\
\hline Sim & 37 & $74 \%$ \\
Não & 13 & $26 \%$ \\
\hline Total & $\mathbf{5 0}$ & $\mathbf{1 0 0} \%$ \\
\hline \hline
\end{tabular}

Fonte: Dados de pesquisa

Os entrevistados manifestaram que preferem, em sua grande maioria, ser bancários, com 37 respondentes. Dentre os restantes, 12 preferem ser consumidores e um manifestou a preferência por ser os dois (Vide Tabela 51).

Tabela 51 - Distribuição dos respondentes da pesquisa por resposta à pergunta "Você prefere ser consumidor ou ser bancário?"- dados coletados nas agências bancárias de julho a outubro de 2007

\begin{tabular}{l|c|c}
\hline Categorias & Quantidade & Freqüência \\
\hline Prefere ser consumidor & 12 & $24 \%$ \\
Prefere ser bancário & 37 & $74 \%$ \\
Prefere ser os dois & 01 & $02 \%$ \\
\hline Total & $\mathbf{5 0}$ & $\mathbf{1 0 0} \%$ \\
\hline \hline
\end{tabular}

Fonte: Dados de pesquisa

Os entrevistados se dividem quando são perguntados se os consumidores são mais importantes que os bancários. A metade, 25 respondentes, acredita que sim e a outra metade acredita que não (Vide Tabela 52). 
Tabela 52 - Distribuição dos respondentes da pesquisa por resposta à pergunta "O consumidor é mais importante que o bancário?"- dados coletados nas agências bancárias de julho a outubro de 2007

\begin{tabular}{l|c|c}
\hline Categorias & Quantidade & Freqüência \\
\hline Sim & 25 & $50 \%$ \\
Não & 25 & $50 \%$ \\
\hline Total & $\mathbf{5 0}$ & $\mathbf{1 0 0} \%$ \\
\hline
\end{tabular}

Fonte: Dados de pesquisa

Quando perguntados da importância do consumidor, a resposta mais citada por entrevistados foi de que os consumidores são importantes para a organização, com 23 respondentes. 14 entrevistados citaram que o consumidor é importante para que ele possa executar seu trabalho e seis descrevem que ele é importante para que a profissão de bancário exista. Dos restantes, quatro descrevem o cliente dentro de uma importância absoluta e três expressam que ele é importante para a manutenção de seus empregos (Vide Tabela 53).

Tabela 53 - Distribuição dos respondentes da pesquisa por resposta à pergunta "Qual é a importância do consumidor?"- dados coletados nas agências bancárias de julho a outubro de 2007

\begin{tabular}{|c|c|c|}
\hline Categorias & Q Quantidade & $\overline{\text { Freqüência }}$ \\
\hline É importante para o banco/organização & 23 & $46 \%$ \\
\hline É importante para a execução do trabalho & 14 & $28 \%$ \\
\hline É importante para que o bancário exista & 06 & $12 \%$ \\
\hline Importância absoluta (importante sem sentido definido) & 04 & $08 \%$ \\
\hline É importante para a manutenção do emprego & 03 & $06 \%$ \\
\hline Total & 50 & $100 \%$ \\
\hline
\end{tabular}

Fonte: Dados de pesquisa

Os dados da pesquisa mostraram que, no que diz respeito aos elementos associados ao trabalho, a organização é o principal elemento de expressão da Identidade Social. O trabalho em si, a categoria profissional, e a organização para a maioria dos entrevistados, afeta na constituição do seu "ser", mas é a organização que se constitui como principal referência em comparação com as demais. Em geral, este vínculo entre a organização e a expressão da Identidade está associado à função social ou ao discurso/política de responsabilidade social da empresa.

Concomitantemente, os aspectos do consumo, o consumo em si e o consumidor afetam na definição do seu "ser", para a maioria dos entrevistados. As expressões das Identidades associadas ao consumo e ao trabalho, embora sejam provenientes de uma contraposição entre papéis distintos dentro do espaço produtivo (o eu-trabalhador e o outro-consumidor) e oriundos de expressões do indivíduo em situações distintas (o eu-trabalhador e o eu- 
consumidor), não se anulam. Pelo contrário, complementam-se de forma que o "Ser Trabalhador" reforça a constituição do "Ser Consumidor" e vice-versa. Os valores do consumo não são impeditivos para a valorização do trabalho, embora o sujeito possa pender para um lado ou para outro.

Neste sentido, o estudo aprofundado de um dos entrevistados que será exposto a seguir, deixa claramente manifesto no discurso do entrevistado essas conexões. Mesmo no caso de estranhamento do trabalho (ANTUNES, 1995) e não identificação com trabalho associada a uma evidente assimilação de valores do consumo, o valor do trabalho e a importância dele para o caso se mostraram presentes no discurso, sem que isso se mostrasse uma incoerência ou inconsistência da fala do bancário. É o que será tratado no "Caso Analu”.

\subsection{O CASO "ANALU"}

Dentre os 50 casos estudados, escolheu-se um para uma análise do indivíduo como um todo e as questões associadas ao tema da pesquisa. "Analu", nome fictício para a entrevistada 15, foi escolhida pelas características demonstradas durante seu discurso, principalmente pela contradição extrema de valores entre o consumo e o trabalho. Ao longo de toda a análise dos resultados, sua fala esteve presente em diversos momentos, mas agora a intenção é dar conexão às falas, interligá-las no intuito de demonstrar a lógica do discurso da entrevistada, bem como os sentidos implícitos nele presentes. A entrevistada permitiu que suas informações fossem expostas, desde que sua Identidade ficasse descaracterizada, não permitindo que fosse reconhecida nem a instituição que trabalha. Por isso, algumas informações foram omitidas e frases foram descaracterizadas para não descumprir o compromisso firmado antes da coleta de dados.

"Analu" é um caso singular, assim como são todos os sujeitos, com pontos em comum entre os demais e diferenças que os fazem únicos. Ela não é um exemplo da maioria, nem se configura como minoria entre os entrevistados.

A entrevista com "Analu" foi muito tranqüila, sendo que ela mostrou-se muito centrada e bastante consciente de suas respostas durante toda a entrevista. "Analu" é uma jovem de 27 anos, recém-casada, não possui filhos, possui curso superior em Arquitetura e tem como principal atividade fora do trabalho a leitura, passear e fazer compras. Na sua própria fala, ela diz que gosta de fazer compras e em função de um processo de dificuldades associadas ao 
trabalho, entrou num processo, descrito por ela mesma como de compulsão consumista.

Até você prometer que isso é sigiloso, no meu processo depressivo, eu adquiri compulsão por compras. Qualquer coisa mesmo. Sapato, roupa, coisa de decoração, comida, qualquer coisa eu gosto de comprar. Primeiro, eu sinto alegria, parece que dá aquele entusiasmo, depois dá um sentimento de culpa terrivel. (Entrevistado 15).

Ela tem consciência de que o seu consumismo é proveniente em parte de uma forma de compensar aspectos negativos do seu trabalho e manifesta sua culpa quando não consegue se controlar. A partir das dificuldades que passou, ela se define.

Uma passagem, mais uma pessoa que está aprendendo com a vida, dos tombos e do levantar. Analu é assim.... bom, muito confuso. (Entrevistado 15).

“Analu” é bancária há pouco tempo. Ela está apenas há três anos nesta profissão, ocupando sempre, neste período, o cargo de atendimento operacional. Ela, embora com tão pouco tempo de instituição, vê o trabalho bancário no passado de forma positiva, de forma glamurosa.

A gente tem um pouco daquela idéia do bancário..., bancário (do Nome do banco) de 30 anos atrás. O quê que você vai ser meu filho? Médico ou trabalhar no (Nome do banco)? Que era bem assim, eram pessoas com salários altíssimos. (Entrevistado 15).

Logicamente, pela idade e pelo tempo de banco, "Analu" não desfrutou este status ou deste este salário. Entretanto, trata-se de uma realidade objetivada e comungada socialmente. Isso lhe dá uma consciência de uma realidade mudada. O presente é uma negação do passado.

[...] hoje em dia, já é um pouco diferente, pelo que eu percebo, a gente tem tantas metas quanto o pessoal dos bancos privados. E a briga é muito grande, tanto internamente quanto externamente, existe briga entre as agências, como se fossem bancos diferentes. Mas o caráter do bancário mudou muito. Hoje em dia, o salário já não é tão bom, aliás, não é bom e as cobranças são maiores. (Entrevistado 15).

A junção da visão do passado e do presente cria uma perspectiva difícil para o futuro da profissão. O fim da profissão leva ao nascimento de outra.

Eu vejo em extinção. O bancário mesmo, eu vejo em extinção. O que vão... o que eu imagino que vai haver são consultores, consultores financeiros. Porque dia após dia, a gente só está lá para resolver problemas. Nós somos gestores de problemas. Então, eu acho que a tendência é o profissional mais específico, que vai ser o consultor financeiro. Ele num vai..., não vai existir mais o bancário do ponto de vista que a gente tem hoje. (Entrevistado 15).

“Analu" acredita que a principal mudança que aconteceu no setor nos últimos anos é o acirramento da concorrência em função das políticas governamentais. 
O aumento da concorrência, principalmente quando o governo permitiu o micro crédito, onde qualquer... hoje em dia, qualquer empresa de arrendamento mercantil pode fazer um financiamento, num precisa necessariamente ser um banco múltiplo. (Entrevistado $15)$.

A entrevistada procura estabelecer uma visão diferenciada para a profissão. Ser bancário para ela, é não ser bancário propriamente dito. Ela tem sua própria estratégia para conviver com sua profissão, que é vista como uma possibilidade de ação social, de auxílio aos outros. Sua ação é uma forma de negar os demais bancários (outros-trabalhadores) que não se preocupam em ajudar, apenas se preocupam em vender, emprestar dentre outras atividades.

Eu faço de tudo, de psicólogo, dou mesmo de psicólogo, de psicólogo e administrador que eu não sou também. Eu faço exercício ilegal das profissões, de várias profissões todos os dias. O pessoal chega precisando de ajuda e ninguém, muitas vezes, está disposto a ajudar. A pessoa num tem muita informação, sabe? Eu como bancária o quê que eu faço? Eu sirvo, só sentada na mesa, porque é uma questão de serviço. O serviço que a pessoa quiser de mim, o que eu puder ajudar, o que eu puder informar, até como função social, eu faço. Entendeu? Mas, basicamente o que quê um bancário faz? Empresta dinheiro, cobra, vende produtos. (Entrevistado 15).

“Analu" não se sente bancária e não se identifica com a categoria. "Não!" Expressa a entrevistada em tom firme, mas de forma calma, sem tecer maiores comentários. Da mesma forma, responde ao perguntar-lhe se ela se identifica com o seu trabalho: "Não!" Acrescenta ainda, quando questionada sobre o que mudaria no seu trabalho, caso pudesse, que mudaria de trabalho, pois vê que é um trabalho limitado.

[...] eu mudaria de trabalho, porque o meu trabalho, eu mudo todo dia. O que eu faço lá sempre, tento fazer todo dia. Agora, num tem jeito de mudar o mundo, como bancário não. (Entrevistado 15).

Além de não se identificar com a categoria, "Analu” tem uma visão negativa da profissão, a qual qualifica com desprezo pela estagnação, pela mediocridade que transparecem para ela.

Ai, meu Deus! Que cambada de gente mediocre, de verdade, porque bancário, qualquer um pode ser. Porque a pessoa que fica estagnada só naquilo, ela se deixa levar pela mediocridade. Me desculpe, mas eu sinto isso. Quando eu chego de manhã, muitas vezes, no banco eu falo assim: Nossa o bancário qualquer um pode ser. É só um pouquinho de treino. E as pessoas, eu vejo gente lá dentro que não seria outra coisa na vida se não fossem bancários. Isso até me dá um pouco de angústia. Eu falo assim: Nossa, fulano, se não fosse o banco heim? Qual que ia ser da vida dessa pessoa. (Entrevistado 15).

Quando questionada sobre a organização, a mesma é descrita sob aspectos positivos e negativos. Entende como sendo uma boa organização, mas as pessoas a "modificam" pelas suas falhas humanas. As vivências pessoais com estes problemas reforçam a idéia de que as pessoas da organização (os demais bancários) são vistas de forma negativa. 
(O Nome do Banco) é uma instituição muito forte. E acho até um lugar bom de se trabalhar. Ele tem respeito às diferenças. Não é lavagem cerebral. Olha, ele incentiva o desenvolvimento profissional das pessoas, ele dá condições para que você se desenvolva, ele tenta te dar qualidade de vida, só que as pessoas estragam o banco. Porque (o Nome do Banco) é composto por... a instituição (Nome do Banco) é uma instituição muito boa, só que as pessoas por ali dentro, como a igreja mesmo, elas modificam pelas falhas que os homens têm mesmo. Então tem assédio moral? Tem assédio moral! Forte! Eu já ameacei um superior de processo de assédio moral, porque se prejudica a qualidade de vida da gente... Tem corrupção? Tem! (Entrevistado 15).

Para ela, o banco não define quem ela é. Entretanto, ela se identifica com os elementos sociais da organização. Por isso, ela se sente uma idealista, alguém que usa a organização para praticar seus ideais. E isso está diretamente associado à visão de bancária que a entrevistada tem. É a psicóloga que atende quem precisa.

(... ) eu me identifico com (o Nome do banco) quando eu me sinto um vetor social, quando eu sei que o que estou fazendo ali é útil, que eu mudei a vida de alguma pessoa que sentou na minha mesa aquele dia. Então, sou nesse aspecto idealista, mas esse idealismo, mas eu me identifico com o banco nesse aspecto. (Entrevistado 15).

Entre ser bancária em outra instituição e continuar a trabalhar na organização onde está, deixando de ser bancária, "Analu” prefere esta última opção. Ela gostaria de exercer a profissão em que se formou dentro do banco, mas ainda espera essa oportunidade.

No Quadro 12, transcreve-se como "Analu" se descreve, enquanto consumidora e enquanto trabalhadora, e como descreve as demais pessoas, como consumidoras e como trabalhadoras. Percebe-se consonância entre as falas anteriores e descrições do eu-consumidor, do eutrabalhador e do outro-consumidor. Entretanto, ao descrever o colega de trabalho ela não estabelece apenas aquela visão negativa da categoria. "Analu" descreve o profissional como alguém que precisa ser bancário para sobreviver (família para criar) e que está sujeito às mesmas regras que ela. 


\section{Quadro 12 - Como o Entrevistado 15 descreve o "eu" e o "outro" nas situações de trabalho e de consumo.}

\begin{tabular}{|c|c|c|c|}
\hline Eu-consumidor & Eu-trabalhador & $\begin{array}{l}\text { Outro-consumidor } \\
\text { (Cliente) }\end{array}$ & $\begin{array}{c}\text { Outro-trabalhador } \\
\text { (Colega de trabalho) }\end{array}$ \\
\hline $\begin{array}{l}\text { - Fujo ao } \\
\text { consumir } \\
\text { - Tento me } \\
\text { controlar } \\
\text { - Compulsiva } \\
\text { - Sou exigente }\end{array}$ & $\begin{array}{l}\text { - Metas } \\
\text { - Psicólogo } \\
\text { - Administrador } \\
\text { - Exercício ilegal da profissão } \\
\text { - Ajuda as pessoas } \\
\text { - A favor do cliente } \\
\text { - Não nasci para ser dondoca } \\
\text { - O trabalho faz a gente se } \\
\text { sentir completo } \\
\text { - Tenta ser igual ao consumidor }\end{array}$ & $\begin{array}{l}\text { - Sem informação } \\
\text { - O cliente tirano e o } \\
\text { que precisa de ajuda }\end{array}$ & $\begin{array}{l}\text { - Está no mesmo barco } \\
\text { - Tem as mesmas metas } \\
\text { - As mesmas pressões } \\
\text { - Não vejo como um número } \\
\text { - Cambada de gente medíocre } \\
\text { - Bancário qualquer um pode } \\
\text { ser } \\
\text { - Estagnada naquilo }\end{array}$ \\
\hline
\end{tabular}

Fonte: Dados de pesquisa

Quando se analisa a fala de "Analu" sobre o consumo e o consumidor, percebe-se que a valorização destes está presente, tanto nos aspectos pessoais, sociais e econômicos. Ser consumidor para "Analu",

É procurar uma coisa que te faz falta, exercendo teu direito de ser bem atendida, sabendo seu dever de atender com cortesia. Noventa por cento não sabe do dever, só sabe do direito. (Entrevistado 15).

O consumidor é a fonte geradora de trabalho, de serviço, para "Analu". Assim ela descreve a importância do consumidor

O cliente é a razão de todo o serviço. Todo serviço que existe no mundo, ele só existe em razão de um cliente. (Entrevistado 15).

É interessante perceber que ela estabelece uma relação de empatia com o consumidor. Neste sentido, ela se vale das referências pessoais que tem como ser-consumidora para definir sua forma de ser-trabalhadora. Ao mesmo tempo ela estabelece uma relação de diferença com os demais consumidores: ela se vê como instruída e os demais sem instrução; eles com a necessidade de ajuda e ela com a capacidade de ajudar.

Costuma ser de igual para igual. Eu me coloco, eu tento desenvolver esse sentimento de empatia, de colocar no lugar do cliente para saber o que ele espera daquilo que estou oferecendo para ele. Tem produto que eu não vendo, aliás (o Nome do banco) têm muitos produtos bons, mas que têm coisas que eu não tenho coragem de vender. Muitas vezes chega um coitadinho que você olha para ele e fala: "Nossa, procurando empréstimo?" E o filho atrás, para fazer empréstimo consignado. Você sabe que ele vai tirar dinheiro da aposentadoria dele para dar para um filho, para um neto comprar uma moto, e a gente vê acontecendo, que ele nunca mais vai ver aquele dinheiro e que ele vai deixar de comprar os remédios dele. Então, para ser sincera, muitas vezes, eu olho e falo: "olha, você não tem direito". É meta do banco isso, é meta empréstimo, mas você sabe que vai trazer um transtorno para aquela família, que vai piorar a qualidade de 
vida daquele pessoal, assim, anos-luz. (Entrevistado 15).

O cliente se constitui numa forma de realização ou de frustração.

Se sente meio que realizado, só que a maioria do retorno que você tem com os clientes, geralmente, é uma coisa muito frustrante. Eu, pelo menos os dias que eu tenho passado no caixa, eu tenho visto o quanto as pessoas são sem educação, quantos não têm empatia. (Entrevistado 15).

Em casos extremos, o cliente chega a ser considerado como um tirano, alguém que não tem consciência, que não tem educação e que chega a ser agressivo em função do excesso de exigência.

Eu percebo que as pessoas, elas são extremamente exigentes, mas elas não conhecem os direitos e os deveres dela como consumidoras e como clientes. Eles tratam as pessoas com descortesia, na maioria das vezes. E o PROCON, quando eu falei de tirania do consumidor, o PROCON ele vem não só para dá um apoio para o consumidor. Porque a gente vê que existe muito abuso. Mas em contrapartida a esse abuso, ele gerou o sentimento de tirania entre as pessoas. É como se consumidor chegasse ao lugar em que ele vai fazer a compra, que ele vai buscar o serviço, com a impressão que ele pode tudo, inclusive desrespeitar a pessoas que estão oferecendo aquilo para ele. (Entrevistado 15).

Por isso mesmo, a entrevistada manifesta que o cliente não é mais importante do quem está trabalhando. Devem ser entendidos como iguais no processo de consumo e produção.

"Analu" afirma que ser-trabalhadora ajudou-a a ser melhor consumidora. Isso porque entende o "outro lado" do processo de produção-consumo. Mais uma vez, ela estabelece uma relação entre ser-consumidora e ser-trabalhadora.

Eu quando eu era só consumidora, talvez eu fosse... eu num tratava com falta de cortesia. Eu acho que eu nunca tratei ninguém. mas o fato de trabalhar do lado de cá, no ponto backoffice, isso me torna uma consumidora melhor, mais noção do que é dever e do que é direito. A maioria das pessoas não consegue fazer esse gancho, porque não vivenciou os dois lados. Então, trabalhar no banco, estar ali na linha de tiro, que é bem isso mesmo, ele me faz perceber o outro lado, que é o lado do consumidor, que ele me faz um consumidor melhor. (Entrevistado 15).

Quando contraposta entre as situações de ser-trabalhadora ou ser-consumidora, "Analu" prefere ser consumidora do que ser bancária. O consumo para ela é fuga e já definiu quem ela é, mas agora se sente controlada.

Consumo é fuga, na maioria das vezes, no meu caso, foi fuga e eu tento me controlar hoje em dia. Mas ele é necessário, bem dosado, bem trabalhado. A gente não pode sair comprando tudo que vem pela frente. Até porque, depois, vem o vazio de pensar para quê que eu comprei isso? [...] (O consumo) Já me definiu mais, já me definiu mais. Hoje me dia eu consigo sair de casa sem comprar e voltar para casa feliz. Eu, ontem, eu cometi um deslize. Eu fui lá no (nome da loja de sapatos) e falei: Nossa Senhora, o sapato que 
custava cento e cinqüenta agora está custando trinta, falei: "nossa vou comprar". Oitocentos reais de sapato, se eu tivesse comprado o valor normal. Gastei 250 no preço à vista. Foi um deslize horrivel, vou ter que conversar mais com minha psicóloga terçafeira, mas já me definiu mais... o consumidor já definiu mais a Analu... hoje em dia ela é menos consumista, um pouquinho. (Entrevistado 15).

Ela acredita que pode conhecer as pessoas pelo consumo

A gente conhece pessoas pelo consumo. O consumo move as pessoas das casas delas para outros ambientes e move as pessoas em pensamento também. Porque existem hoje os consumidores que usam a Internet, que são pessoas que não saem de casa para manter suas relações de troca, mas eu acredito que o consumo, ele seja alguma diretriz... ele inicia movimento e, de repente, toma um impulso. Um movimento que é um movimento humano, que é um movimento financeiro, mas que é um movimento, que está ali. (Entrevistado 15).

Embora "Analu" mostre em sua fala que os valores do consumo estão presentes em seu cotidiano, que o consumidor e ser consumidor tem sua importância, o trabalho tem uma representação em termos de valor moral, sendo responsável por definir quem ela é, em sua própria concepção.

Eu não consigo me imaginar parada, não nasci para ser dondoca, sabe aquela coisa de ficar: ah! O que é que eu vou fazer. Eu não consigo ficar parada, eu não sou workaholic, não sou. Mas o trabalho é bem aquela coisa do Lutero: o trabalho dignifica o homem. Eu acho que a gente é digno por fazer alguma coisa em prol de alguém, e só fazer essa uma coisa já é trabalho para mim. Então, não sei, para mim trabalho, ele é tudo, porque através dele que eu tiro o sustento da minha família. Se (o nome do marido) não trabalhasse também? A gente precisa do nosso trabalho para sobreviver, o trabalho faz a gente se sentir completo, dia após dia. ( $\mathrm{O}$ trabalho) faz a gente crescer como pessoa assim... aquela responsabilidade de estar ali a serviço. Ele te gera internamente uma sessão de responsabilidade que te move, ela que te faz levantar todo dia. Não é como responsabilidade do ponto negativo não, é a responsabilidade de você ser importante naquilo que você faz, da tua presença ali ser importante. (Entrevistado 15).

“Analu" não se sente bancária, não se identifica com a categoria, a organização não a define, embora se identifique com as práticas sociais que executa na Instituição. Ao mesmo tempo, gosta de comprar, se define como consumista, entende a importância do consumidor e de ser consumidor. Mesmo neste extremo, o trabalho é descrito por ela mesma como elemento definidor do seu ser. Ela precisa do trabalho e o trabalho a define por mais "estranhado", na concepção de Antunes (1995), que ele possa se configurar. Para tanto, mesmo que não estabeleça uma relação de proximidade com a profissão, "Analu" cria um vínculo diferenciado com seu trabalho, uma forma de representá-lo diferente do que acredita que o trabalho bancário é. Ela não é bancária, em suas próprias palavras é um “vetor social”. 


\subsection{O FOCUS GROUP}

Durante o focus group, discutiu-se com os bancários participantes os resultados da pesquisa, procurando analisar se há, por parte deles, algum resultado que lhes pareça estranho ou que contradiga a realidade em que vivem. Utilizou-se como roteiro para as questões, os resultados da pesquisa. Todavia, o grupo foi conduzido como uma espécie de diálogo coletivo, inserindo questões que foram julgadas como oportunas e respondendo a questionamentos dos participantes.

A primeira questão que foi debatida com os bancários é o desenho teórico da pesquisa, em que se procurou expor o que estava sendo discutido pelo estudo. Os participantes do focus group corroboraram as transformações objetivas acontecidas no trabalho bancário, assim como os entrevistados individuais, dando destaque para as mudanças de ordem tecnológica e a redução dos postos de trabalho.

Quando questionados sobre a mudança da forma como o consumidor se posiciona hoje no setor, os bancários relataram que houve um reordenamento da importância dos clientes para as instituições, muito visível no cotidiano de suas atividades. Entretanto, foi ponderado que, embora os bancos profiram um discurso sistemático de que o cliente é o elemento mais relevante no contexto atual, essa prática, na concepção deles, é mais apelo mercadológico do que realidade, ou seja, uma falácia. Para eles, os acionistas querem mesmo é obter seus lucros, independente de como isso venha a ser feito. Sendo preciso proferir um discurso de "salvem as baleias" para abrir mais contas, comentou sarcasticamente um participante, "amanhã estaremos defendendo as baleias do mar de Minas Gerais”. Apenas um participante comentou que há uma tendência de que os bancos comecem a disseminar o uso racional do crédito, ou seja, de, cada vez mais, orientar para que o cliente não abuse do uso de produtos bancários, uma vez que esse abuso tem como resultado o aumento de inadimplência. "Perceberam que estavam matando a galinha dos ovos de ouro" afirmou o participante.

Há um descompasso entre o que é passado para o cliente e o que o banco realmente faz para alguns dos participantes. O banco vende uma imagem que não existe. Isso faz com que os clientes sejam cada vez mais exigentes, uma vez que suas expectativas são aumentadas. Um participante exemplificou que o banco em que trabalha, para alguns clientes, oferece contas especiais com diferencial em termos de status, como se fossem "VIPs". Entretanto, o volume de trabalho e a falta de uma estrutura específica da agência resultam que os consumidores 
diferenciados enfrentam filas e são atendidos da mesma forma, embora paguem tarifas mais caras. Isso gera reclamação do cliente sobre a agência e sobre o bancário. "Se o banco realmente se importasse com o cliente, investiria mais no bancário e na agência”, desabafa um participante.

Ao serem expostos os resultados sobre as categorias "Valor do Trabalho" e "Valor do Consumo" abordados pela pesquisa, não houve qualquer comentário acrescido ao tema. Foi lhes questionado, então, se o bancário tem uma visão diferente das outras pessoas sobre o valor do dinheiro, na medida em que essa hipótese foi relatada por um entrevistado. Foi interessante perceber que os participantes concordaram que o bancário possui uma concepção diferenciada sobre o dinheiro. Para eles, as pessoas, em geral, não têm noção do valor do dinheiro e o utilizam de forma indiscriminada. Quando perguntado se isso não seria bom para que eles pudessem vender mais os produtos bancários, eles entendem que sim, mas têm a consciência de que os clientes estão passando dos próprios limites.

“O bancário sabe mais sobre seus limites do que pode ou não pode consumir?” A questão gerou um certo debate, pois todos conhecem colegas de trabalho que passam por dificuldades financeiras, ou porque não souberam se controlar ou fizeram opções erradas de investimento. O que difere o bancário, na concepção de um respondente que foi corroborado pelos demais, é que ele faz de forma consciente, tendo conhecimento dos riscos, uma vez que vê, todos os dias, pessoas com problemas financeiros. Outro ponto importante que foi comentado é que existe uma prática, por parte dos bancos, de inibir o endividamento por parte dos bancários. As razões para estas práticas foram divergentes entre os entrevistados, embora compartilhem dessa mesma concepção. Para uns, isso porque são a "vitrine do banco" e não podem passar uma imagem ruim da instituição, como se fossem pessoas que não sabem lidar com o próprio dinheiro. Também foi citado que, pelo fato de lidarem com dinheiro dos outros todos os dias, é preciso não ter dívidas para não gerar qualquer tipo de dúvida sobre as ações do bancário no trabalho. Os participantes citaram casos de suspeita de roubo de dinheiro entre colegas de trabalho, de fraudes de bancários sobre clientes idosos e até de envolvimento com assaltantes de bancos.

No que diz respeito à categoria "Ser Trabalhador", os participantes revelaram que algumas frases fazem mais sentido do que outras para a realidade em que vivem. Entretanto, nenhuma definição pareceu estranha ao contexto bancário. O único item que gerou dúvidas foi a 
definição "Ter status ou ser importante" (13 item da Tabela 32), pois, para eles, o bancário perdeu status. Entretanto, foi-lhes explicado que tal afirmação foi colocada em comparação às demais profissões do mercado e não em relação ao profissional do passado.

O "Ser Consumidor" também possui definições compartilhadas pelos participantes. Não houve qualquer questionamento sobre as afirmações. Foi-lhes questionado sobre as interligações entre o "Ser Trabalhador" e o "Ser Consumidor" e houve uma concordância com as relações estabelecidas pela exposição dos resultados. Os participantes descreveram que suas relações com os clientes os afetam muito, tanto como consumidores quanto como trabalhadores. Há, na visão deles, compartilhamento de experiências e frustrações, o que gera um sentimento de identificação, mesmo quando os clientes estão muito nervosos. Entretanto, não concordam com a forma como são tratados por alguns consumidores e procuram não reproduzir tal agressividade quando estão do outro lado, ou seja, como clientes. Foi lhes questionado sobre como lidam com os clientes que chegam agressivos e cada um expressou uma estratégia diferente, mas a situação sempre os deixa apreensivos, nervosos e, em alguns casos, deprimidos depois do dia de trabalho. Um participante expressou que os clientes não são mais importantes do que os bancários, mas sentem que estão numa relação desigual, em que o cliente sempre está respaldado, seja pelo PROCON, seja pela imagem que o banco vendeu ou seja pela postura do gerente da agência. "Quando o banco erra, é o bancário que paga o pato", expressou o participante.

No que diz respeito à categoria elementos de expressões da Identidade Social, os participantes manifestaram que o trabalho é parte da vida pública que têm, principalmente quando associando ao contexto de uma cidade de médio porte. Foi exposto aos participantes que o nome do banco é muito utilizado como referência pelos bancários para expressar quem são para os outros e, então, foi lhes perguntado se isso não contradiz a visão que eles têm da organização, uma vez que o banco é descrito por alguns de forma negativa. Duas explicações foram dadas para esta situação. A primeira é que a organização é uma coisa e os acionistas são outra coisa, embora sejam ditos como sinônimos. A organização é um bom lugar para se trabalhar e possui um papel social, na visão do participante, mas os acionistas exigem que o banco aja pensando sempre em curto prazo, por resultados rápidos e contínuos, de forma que "a gestão da empresa se dobra aos interesses dos que detêm o controle acionário". A segunda explicação é que o banco é referência, seja boa ou ruim, de quem eles são. As pessoas os conhecem pela organização, principalmente numa cidade de menor porte. Um participante 
relatou um caso em que, ao passear com a família, um cliente começou uma discussão verbal questionando "como ele tinha coragem de colocá-lo na lista do SERASA?", como se ele fosse o banco. "O pior", acrescentou, "é que nem foi o banco que o colocou naquela situação". "Às vezes", comentou outro participante, "porque nos vestimos bem, os clientes confundem o lucro dos bancos anunciados no Jornal Nacional com os nossos salários... quem dera!”.

Um dos participantes do focus group salientou, quando foram apresentados os dados que mostram que os bancários preferem permanecer na organização do que continuar sendo bancários, que mudar de organização não vai alterar as condições de pressão e a forma como deverão executar suas tarefas, pois o contexto é igual em todas as organizações, inclusive para os que trabalham em bancos públicos. Permanecer na organização em outra profissão, segundo o relato dele, é a possibilidade de sair da "rotina do operacional de agência", mantendo os benefícios oferecidos pela instituição.

Não houve comentários que acrescentassem informações sobre a expressão de identidade associada ao consumo e ao consumidor, de forma que os participantes apenas comentaram que as informações despertaram interesse sobre o assunto.

A partir do focus group, não se detectou que tenha havido grandes disparidades entre a análise dos dados e visão que os participantes têm de seu cotidiano, apenas algumas informações foram acrescentadas para se compreender os resultados da pesquisa. Entretanto, acredita-se que essa estratégia foi importante feedback para fechar as conclusões e (in)conclusões desta tese. 
Às vezes a realidade, depois de conhecida, parece tão óbvia que esquecemos que nada é óbvio até que alguém conheça. 
A análise dos dados coletados nesta pesquisa mostrou que as transformações do contexto, sejam elas objetivas e específicas do setor bancário, ou sejam elas subjetivas como a valorização do consumo e do consumidor, estão presentes nos discursos dos entrevistados, denotando que tais profissionais expressam que estão submetidos a uma realidade laboral bastante distinta da que tinham nas décadas passadas. Neste sentido, entende-se que os bancários que participaram da pesquisa demonstram ter consciência das mudanças e, portanto, tornam-se capazes de contrapor a realidade atual com a realidade vivida em anos anteriores. Destaca-se que até mesmo os bancários com pouco tempo na profissão compartilham essa visão das transformações, uma vez que tais informações e experiências do passado foram socializadas pelos bancários mais antigos.

Em termos das transformações objetivas, foi possível captar que o bancário mudou a forma como executa e compreende seu trabalho. O bancário de hoje é diferente do bancário do passado, assim como o seu trabalho, corroborando as afirmações de Merlo e Barbarini (2002). Os bancários também relataram de forma expressiva as descrições da reestruturação produtiva que o setor sofreu na década de 1990, como descrito pelo DIEESE (1997 e 2007). As constatações de Grisci e Bessi (2004) sobre a necessidade de que o bancário reaprendesse a trabalhar e a lidar com novos modos de subjetivação, bem como a pressão para vender os produtos financeiros e a perda do status da categoria, ficaram evidenciadas como pano de fundo em muitas das questões envolvendo o cotidiano do profissional.

Ainda dentre os aspectos objetivos, percebe-se que o consumidor é um elemento central na rotina dos bancos, sendo que, como foi relatado, a importância e a forma como ele é tratado e compreendido pelos bancários mudou consideravelmente nos últimos anos. Neste sentido, o bancário também precisou se reposicionar perante o novo tipo de cliente, mais exigente, mais respaldado e mais valorizado, pelo menos em discurso, pelas organizações.

Também foi possível observar, dentro do contexto das transformações subjetivas, a valorização do consumo no discurso dos entrevistados. Valor este que se mostrou presente na fala de diversos entrevistados em termos pessoais e econômicos, embora tenha aparecido como valor moral negativo também. Como valor social, embora não tanto quanto os demais valores, o consumo também foi citado predominantemente como positivo. Foi possível observar que o consumo se faz presente não só como uma forma de suprir carências materiais de sobrevivência, mas como forma de prazer, de liberdade, de se sentir completo de 
satisfação, de busca de felicidade por meio da realização dos projetos materiais de vida.

Os valores pessoais, econômicos, morais associados ao trabalho também se mostraram muito presentes no discurso dos entrevistados, igualmente de forma positiva. Ele foi descrito como a forma de realização, de sobrevivência, de dignificação do ser humano. Por meio dele o trabalhador se sente útil. A fala dos entrevistados mostrou que o trabalho ainda se configura como um forte referencial para a constituição dos sujeitos sociais.

Embora, como descrito por Arendt (2004), o consumo e o trabalho estejam distanciados em termos objetivos, de forma que aquilo que o indivíduo produz nem sempre ele consome, há uma forte conexão entre os dois, um vínculo de complementaridade em termos de seus valores, como se o trabalho, em termos morais, redimisse os pecados do consumo ou como se o trabalho legitimasse, justificasse o consumo. Por outro lado, nos valores pessoais, o consumo é uma compensação prazerosa pelo desgaste, pelo sofrimento do trabalho, ou como prêmio por sua execução bem feita.

A construção das Identidades a partir do outro, como descrito por Woodward (2000), mostrou que há uma interligação entre o consumo e o trabalho, principalmente na relação entre o eutrabalhador e o outro-consumidor. $\mathrm{Na}$ construção que os bancários fazem do "Ser Trabalhador" há diversas conexões com o "Ser Consumidor", de tal maneira que para definir o primeiro utiliza-se como forma recursiva o segundo. O "Ser Trabalhador" depende do "Ser Consumidor" para se constituir em termos dos papéis sociais, da forma de atuação do bancário e dos sentimentos associados ao trabalho. O "Ser Trabalhador" não se anula na presença do "Ser Consumidor", pelo contrário, ele se afirma, se define, ganha conotações próprias.

Complementarmente, o "Ser Consumidor", no que diz respeito à sua forma de atuação durante o consumo, possui relações diretas com "Ser Trabalhador" na medida em que este convive com outros "Seres Consumidores" durante a execução de suas atividades no trabalho. Ele aprende com erros e acertos alheios e reage de forma semelhante aos consumidores com os quais convive e que estabelece processos de identificação, numa relação de "espelhamento", como descrito por Berger e Luckmann (1985). A cada relação social que se estabelece, o bancário reconstrói suas tipificações do "Ser Consumidor" e do "Ser Trabalhador" de forma que suas referências mudam de sentido, mas continuam como referências. 
Na medida em que as tipificações foram modificadas pelas mudanças contextuais, o bancário estabelece novas estratégias, novas formas para lidar com seu cotidiano e para se constituir enquanto sujeito social. Dessa forma, é preciso estabelecer novas maneiras de se relacionar com o trabalho e com o outro, seja este último consumidor ou trabalhador. O trabalho continua sendo uma referência para o indivíduo, entretanto, o consumidor e o consumo tornam-se pontos de referência para seu trabalho. É por isso que o consumidor se configura como uma forma de expressão de realização ou de frustração, pois é, em síntese, a nova forma como seu trabalho se concretiza.

Enquanto elemento de expressão da Identidade Social, o trabalho ainda pode ser considerado como expressivo, pelo que foi depreendido pelas falas dos entrevistados. Entretanto, não pode ser entendido da mesma forma que outrora. O trabalho bancário ainda padece das modificações que estão acontecendo em termos tecnológicos, gerenciais e sociais, não tendo elementos cristalizados que sirvam de referência para o indivíduo. Os entrevistados se sentem bancários, mas não "aqueles bancários de outrora"; são outros bancários, os de hoje. O que é ser bancário? Ser vendedor? Ser consultor? Ser psicólogo? A certeza que se tem é que ser bancário hoje não é ser como o bancário de antigamente. E o futuro é marcado por uma visão negativa, que leva ao temor do fim da profissão.

Os bancários se compreendem como parte de uma categoria, mas não no sentido de união ou coesão. Um coletivo que compete entre si, que já não é mais tão unido, que não tem o status e o poder de antes. Sentem que são parte de um agrupamento e não de um coletivo estruturado e organizado politicamente.

A organização, enquanto entidade social, aparenta ser o refúgio lógico e visível para que os bancários manifestem quem são, corroborando as constatações de Caldas (1999). São as organizações que estão presentes no ideário do consumidor, e, portanto, sendo pontos de referência social. O consumidor as conhece pelo nome e conhece os trabalhadores dela pelos "seus sobrenomes". Os bancários, entretanto, estabelecem processos de identificação com o discurso ou com a política de responsabilidade social do banco, em alguns casos, ou com a função social da entidade. Metaforicamente dizendo, é melhor ter o sobrenome de uma entidade que é conhecida como de "boa índole".

Ao contrário do que Sennet (2004) apontou, em outra realidade distinta da que vivemos, o trabalho ainda é um espaço de construção referencial para o indivíduo, principalmente porque 
ainda vive-se sob a égide moral do trabalho. Entretanto, reitera-se que não se pode pensar dentro da mesma lógica de trabalho que antes. Por mais "estranhado" que o trabalho seja para o sujeito, como apontou Antunes (1995), ele continua sendo um elemento importante para o sujeito social. As metamorfoses do trabalho modificaram objetivamente o trabalho e subjetivamente a forma como os indivíduos lidam com ele, mas não a construção social que os bancários fazem, em termos de sua importância ou valor como referência. Essa constatação vai de encontro com a perspectiva construcionista de Berger e Luckman (1985) e de Spink e Frezza (1999), na medida em que a realidade se constrói no sujeito e não fora dele.

Os resultados da pesquisa também mostram a necessidade de esta pesquisa seja complementada com estudos posteriores, que se discute no capítulo que se segue. 


\section{CAPÍTULO 6 - (IN)CONCLUSÕES E RECOMENDAÇÕES}

Uma tese é como a construção de uma casa. Você nunca termina. Chega uma hora que você tem que abandonar a construção e morar nela, mesmo cheia de (in)conclusões. Quando você pára para pensar, o custo, principalmente o pessoal, extrapolou o orçamento inicial. Mas não tem valor que pague o preço de ter seu próprio lar. Você começa a gostar até dos defeitos. 
Este estudo também deixa questões consideradas importantes, mas que, em função do propósito da pesquisa, não foram desenvolvidas. Também é importante ter em mente que as opções metodológicas geraram potencialidades e limitações que precisam ser expressas para que futuros pesquisadores possam aperfeiçoar estudos dessa natureza.

Primeiramente, deve-se evidenciar que a maioria dos autores utilizados para descrever o atual contexto é oriunda de uma realidade diferente da brasileira, onde o consumo e ser consumidor possuem características bem distintas. Entretanto, é certo que os movimentos de globalização dos mercados tendem a aproximar essas realidades, fazendo com que as preocupações de tais autores sejam igualmente nossas. Sugere-se, nesse sentido, que outros estudos enfatizem a compreensão das conexões entre o consumo e o trabalho no contexto brasileiro, entendendo que isso pode contribuir para elucidar nossas especificidades.

É importante compreender que, na medida em que se fez um corte transversal como opção metodológica, serão necessários novos estudos para compreender a realidade estudada, entendendo que as mudanças no trabalho e no consumo ainda estão se consolidando. Neste sentido, recomenda-se que sejam realizadas pesquisas para entender como o trabalho e o consumo e suas mudanças irão afetar em longo prazo. Pode-se cogitar que algumas das constatações feitas pela pesquisa ainda podem ser modificadas, uma vez que as próximas gerações irão assimilar com mais profundidade os valores da sociedade do consumo.

A opção por uma abordagem qualitativa implica, como foi exposto na metodologia, que não há intenção de constituir uma amostra representativa, pois objetiva estudar em profundidade, sem tecer generalizações. Além disso, a escolha pelo estudo exploratório e descritivo também condicionou os resultados de forma a limitá-los na compreensão sobre conexões e das relações causais entre as categorias de análise. Dessa forma, espera-se que estudos posteriores possam se apropriar dos conteúdos e resultados dessa tese para desenvolver pesquisas quantitativas que possibilitem generalizações dos achados aqui expostos.

A escolha da categoria bancária para o estudo foi significativamente importante para entender o tema, entretanto, algumas de suas especificidades podem restringir o escopo das análises somente ao setor estudado. Os entrevistados são parte de uma categoria que possui um elevado grau de instrução formal. Além disso, o fato de lidaram com pessoas endividadas gerou resultados específicos sobre a visão do consumo e sobre os consumidores. Recomendase, dessa forma, que outras categorias profissionais também sejam estudadas, buscando 
corroborar ou refutar os achados deste estudo.

Percebeu-se também que o fato de realizar a pesquisa em uma cidade de médio porte pode ter afetado parte dos resultados da pesquisa, na medida em que as pessoas se conhecem e estão mais próximas. Além disso, um dos entrevistados relatou que há entre os bancários da capital um sentido de mobilização maior. Entretanto, não se considera este fato como uma limitação da pesquisa, pois as agências do interior também fazem parte da realidade bancária, uma vez que há dispersão geográfica desses estabelecimentos no país.

Expõe-se que ainda é preciso realizar outros estudos sobre as Identidades Sociais dentro das organizações, associando-a a outros constructos e variáveis. É preciso saber mais sobre como os sujeitos se constroem no espaço laboral e como as mudanças estão afetando os indivíduos, ou seja, precisamos nos entender, cada vez mais, enquanto produtores de nossas realidades dentro das organizações.

Por fim, retorna-se ao começo das indagações, lembrando que o crescimento desenfreado do consumo talvez seja um dos grandes desafios sociais aos quais a humanidade está submetida, e os problemas associados a essa temática ainda estão distantes de soluções concretas. $\mathrm{O}$ modelo de crescimento da Era Moderna, estando ou não em um processo de recrudescimento ou esfacelamento, ainda gera problemas ambientais, econômicos e sociais de tal sorte que a necessidade de se repensar as opções para o futuro já nos foi incondicionalmente imposta. É preciso repensar a relação que o homem estabeleceu com sua realidade ambiental, social e, principalmente, consigo mesmo. 
ACCORSI, A. Automação bancária e seus impactos: o caso brasileiro. Revista de Administração. São Paulo, v.27, n.4. p. 39-46, out./dez., 1992.

AKtouf, O. Novas perspectivas em gerência e nas teorias das organizações. Material didático. Belo Horizonte: CEPEAD/FACE/UFMG, 25 a 29 de maio de 1998.

Albuquerque, L.G. A gestão estratégica de pessoas. In: Limongi-FranÇA, A.C. et al. As pessoas na organização. 4. ed. São Paulo: Editora Gente, 2002.

ANTUNES, R. Adeus ao trabalho? Ensaio sobre as metamorfoses e a centralidade do mundo do trabalho. São Paulo: Cortez, 1995.

Arendt, H. A condição humana. 10. ed. Tradução de Roberto Raposo. Rio de Janeiro: Forense Universitária, 2004.

ARON, R. O marxismo de Marx. Tradução de Jorge Bastos. São Paulo: Arx, 2003.

ASHFORTH, B.E.; MAEL, F. Social identity and the organization. In: Academy of management review, v.14, n.1, jan/1989 apud SteVAnAto, L. A. Um estudo sobre a construção da identidade social dos profissionais de e-business. São Paulo: FEA/USP, 2004. (Tese de Doutorado em Administração).

Assunção, A. A. A saúde bancária na era moderna: fatores de risco. Saúde no trabalho bancário. São Paulo, Central Única dos Trabalhadores, 1993.

BARDIN, L. Análise de conteúdo. Lisboa: Edições 70, 1977.

BARUS-Michel, J. O sujeito social. Tradução Eunice Galery e Virgínia Mata Machado. Belo Horizonte: Editora PUC Minas, 2004.

BAUDRILLARD, J. A sociedade de consumo. Lisboa: Edições 70, 1991.

BAUMAN, Z. O mal-estar da pós-modernidade. Tradução, Mauro Gama, Cláudia Martinelli Gama. Rio de Janeiro: Jorge Zahar Ed., 1998.

Identidade: entrevista a Benedetto Vecchi. Tradução, Carlos Alberto Medeiros. Rio de Janeiro: Jorge Zahar Ed., 2005. 
Berger, P.; Luckmann, T. A construção social da realidade: tratado de sociologia do conhecimento. 24. ed. Tradução de Floriano de Souza Fernandes. Petrópolis: Vozes, 1985.

BorzeIX, A.; LINHART, D. Identidades e práticas lingüísticas na empresa. In: CHANLAT, J.F. (org) O indivíduo na organização: dimensões esquecidas. V.III. São Paulo: Atlas, 1996.

Bourguignon, D. Elementos de análise na construção do perfil epidemiológico de trabalhadores do Banco do Estado do Espírito Santo. Simpósio Saúde Mental E Trabalho BANCÁRIO. Anais... Vitória: Gráfica Santo Antônio, 1997.

Braverman, H. Trabalho e capital monopolista: a degradação do trabalho no século XX. 3 . ed. Rio de Janeiro: LTC, 1987.

CAldas, M. P.. A demissão e alguns significados psicológicos da perda do emprego para o indivíduo. In: 23 ENANPAD, 1999, Foz do Iguaçú. Anais..., 1999.

CASSIRER, E. Ensaio sobre o homem: introdução a uma filosofia da cultura humana. Tradução Tomás Rosa Bueno. São Paulo: Martins Fontes, 1994 (Coleção Tópicos).

Chesnais, F. A mundialização do capital. Tradução Silvana Finzi Foá. São Paulo: Xamã, 1996.

CHILD, J. Estratégias gerenciales, nueva tecnologia y proceso del trabajo. In: CASTILLO, J.J. (org) La automación y el futuro del trabajo: diseño del trabajo y cualificación de los trabajadores. 2. ed. Madri: Ministério de Trabajo y Seguridad Social, 1991.

Ciampa, A. C. A estória do Severino e a história da Severina: um ensaio de psicologia social. São Paulo: Brasiliense, 2005.

Codo, W. ; Sampaio, J. J. C. . Síndrome do Trabalho Vazio Entre Bancários. Jornal Brasileiro De Psiquiatria, 1992.

Coelho, L.A.L. Tal objeto tal dono. In: LOPES, L.P.M.; BASTOS, L.C. (orgs). Identidades: recortes multi e interdisciplinares. Campinas: Mercado de Letras, 2002.

COMISSÃo DE PÓS-GRAdUAÇÃO DA FEA/USP. Manual para formatação e edição de dissertações e teses. São Paulo: FEA/USP, 2004. 
CoOPer, D.R.; Schindler, P.S. Métodos de pesquisa em administração. 7. ed. Porto Alegre: Bookman, 2003.

COUTO. H.A. O fenômeno LER/DORT no Brasil: natureza, determinantes e alternativas das organizações e dos demais atores sociais para lidar com a questão. Belo Horizonte: Centro de Pesquisas e Pós-Graduação em Administração da Faculdade de Ciências Econômicas da Universidade Federal de Minas Gerais, 2000 (Tese de Doutorado em Administração).

DeDECCA, C.S. Desemprego e regulação no Brasil hoje. Cadernos do CESIT, n.20, ago. 1996.

De Masi, D. O futuro do trabalho: fadiga e ócio na sociedade pós-industrial. 4. ed. Tradução: Yadyr A. Figueiredo. Rio de Janeiro: José Olympio; Brasília: Ed. da UnB, 2000.

DIEESE. Mudanças no perfil da categoria bancária: ocupação gênero, escolaridade e faixa etária (1986-1994). São Paulo: DIEESE, 1997.

.Reestruturação produtiva. Julho de 1997(b). Disponível em < www.dieese.org.br/esp/estjul97.xml>. Acesso em 24/01/2008.

Evolução Recente do emprego bancário no Brasil. Belo Horizonte: DIEESE, 1998.

Admissões e demissões no setor bancário. Nota Técnica. n. 38, Out. 2006.

Uma análise da margem de ganho dos bancos. Nota Técnica. n. 35, Out. 2006(b).

As receitas de prestação de serviços dos bancos. Brasília: DIEESE, Junho de 2006(c).

Fusões no setor bancário: emprego e concorrência. Nota Técnica. n. 55, Nov. 2007.

EBoli, M.P. Relações de trabalho no Banco do Brasil: problemas e desafios. Revista de Administração. São Paulo, v.27, n.4, p. 47-57, out./dez. de 1992.

ELy, H.B. Mudanças tecnológicas nos bancos brasileiros. São Paulo: SESE/SEEB-SP, 1993.

EnRIQuez, E. Perda do Trabalho, perda da identidade.in: NABUCO, M.R.; Neto, A.C. (orgs) 
Relações de trabalho contemporâneas. Belo Horizonte: Instituto de Relações de Trabalho da Pontifícia Universidade Católica de Minas Gerais, 1999.

ERIKSON, E.H. Identity: Youth and Crisis. New York: Norton, 1968, apud Gustavsson, B. The Ethics of Managing Corporate Identity. Sage Publications New Delhi/Thousand Oaks/London. Journal Of Human Values. 11:1, 2005.

FALQUeto, M. G. F. B. Construção social da identidade bancária: o que é ser bancário?” In: Simpósio de saúde mental e trabalho bancário. Anais... Vitória (ES): Universidade Federal do Espírito Santo, 1997.

FEBRABAN. Portal de Informações. Disponível em: $<$ http://www.febraban.org.br/portaldeinformacoes/>. Acesso em 24/01/2008.

FISCHER, G.N. Espaço, Identidade e Organização. In: ChANLAT, J.F. (org) O indivíduo na organização: dimensões esquecidas. V.II. São Paulo: Atlas, 1996.

FISCHER, R. M. Pondo os pingos nos "is" sobre as relações de trabalho e as políticas de administração de recursos humanos. In: Processos de Relações de trabalho no Brasil. São Paulo: Atlas, 1985.

FLICK, U. Uma introdução à Pesquisa Qualitativa. 2. ed. Tradução Sandra Netz. Porto Alegre: Bookman, 2004.

Freitas, M.C.S. A qualificação do bancário na era da informática: um estudo de caso sobre o treinamento dos caixas do Banco do Brasil. Niterói: Universidade Federal Fluminense, 1995 (Dissertação de Mestrado em Educação e Trabalho).

Gaulejac, V. Identité. In: Barus-Michel, J.; EnRiQuez, E.; LeVy, A.(orgs) Vocabulaire de psychosociologie: références et positions. Toulouse: Érès, 2002.

Gerger, K. The social constructionist movement in modern Psycology. In American Psychologist, 40 (3), 1985 apud Spink, M.J.; Frezza, R.M. Práticas discursivas e produção dos sentidos: a perspective da Psicologia Social. In Spink, M.J. (org) Práticas Discursivas e produção de sentidos no cotidiano: aproximações teóricas e metodológicas. São Paulo: Cortez, 1999. 
GIDDENS, A. As conseqüências da modernidade. Tradução de Raul Fiker. São Paulo: Editora da Universidade Estadual Paulista, 1991.

. Modernidade e Identidade. Tradução Plínio Dentzien. Rio de Janeiro: Jorge Zahar Ed., 2002.

GIL, A. C. Como elaborar projetos de pesquisa. São Paulo: Atlas, 1988.

Métodos e técnicas de pesquisa social. 5. Ed. São Paulo: Atlas, 1999.

Gomes, M. H. T. S. Qualificação e a organização do trabalho no setor bancário: uma discussão sobre a automação. Rio de Janeiro: Universidade Federal de Minas Gerais, 1994 (Dissertação de Mestrado em Engenharia da Produção).

GorZ, A. Adeus ao proletariado. Rio de Janeiro: Florence, 1982.

GRISCI, C.L.I.; BESSI, V.G. Modos de trabalhar e de ser na reestruturação bancária Sociologias, Porto Alegre, ano 6, no 12, jul/dez 2004, p. 160-200.

Gustavsson, B. The Ethics of Managing Corporate Identity. Sage Publications New Delhi/Thousand Oaks/London. Journal Of Human Values. 11:1, 2005.

HALL, S. A identidade cultural na pós-modernidade. 3. ed. Rio de Janeiro: DP\&A, 1999. Quem precisa da identidade? In: SilvA, T.T. (org) Identidade e diferença: a perspectiva dos estudos culturais. 2. ed. Petrópolis, RJ: Vozes, 2000.

JACKSON, J.W.; Smith, E.R. Conceptualizing Social Identity: A New Framework and Evidence for the Impact of Different Dimensions. Personality and Social Psychology Bulletin, 1999. Extraído de [ http://psp.sagepub.com/cgi/content/abstract/25/1/120] em $12 / 03 / 2007$.

KERLINGER, F.N. Metodologia da pesquisa em ciências sociais: um tratamento conceitual. São Paulo: EPU/Edusp, 1979. apud GIL, A. C. Métodos e técnicas de pesquisa social. 5. Ed. São Paulo: Atlas, 1999.

Laurenti, C.; Barros, M. N. F. Identidade: questões conceituais e contextuais. Revista Digital de Psicologia da Universidade Estadual de Londrina. Londrina, Universidade 
Estadual de Londrina, v2., n1, Jun/2000. [www2.uel.br/ccb/psicologia/revista] acessso em $01 / 06 / 2004$.

LiMONGI-FrANÇA, A.C. Era uma vez um certo "Lambari" - Um estudo sobre as respostas psicossomáticas na empresa, desde o julgamento 'só -psicológico'a revelação social. São Paulo: Pontifícia Universidade Católica de São Paulo, 1990. (Dissertação de Mestrado).

Qualidade de vida no trabalho - QVT: conceitos e práticas nas empresas da sociedade pós-industrial. 2. ed. São Paulo: Atlas, 2004.

LINHART, D. Crisis y trabajo. In: CASTILLO, J.J. (org) La automación y el futuro del trabajo: diseño del trabajo y cualificación de los trabajadores. 2. ed. Madri: Ministério de Trabajo y Seguridad Social, 1991.

LutTwak, E. O capitalismo turbinado e suas conseqüências. Novos estudos. São Paulo: CEBRAP, n.45, p. 58-64, Jul., 1996.

Machado, H. V. A Identidade e o Contexto Organizacional: Perspectivas de Análise. Revista de Administração Contemporânea. Edição Especial. 2003: 51-73.

Maturana, H. R.; Varela F. G. A árvore do conhecimento humano: as bases biológicas do entendimento humano. Campinas: Editorial Psy II, 1995.

MERCER, K. Welcome to the jungle. In: RUTHERFORD, J. (org). Identity: community, culture, difference. Londres: Lawrence and Wishart, 1990 apud WOODWARD, K. Identidade e diferença: uma introdução teórica e conceitual. In: Silva, Tomaz Tadeu da (org) Identidade e diferença: a perspectiva dos estudos culturais. 2. ed. Petrópolis, RJ: Vozes 2000.

MERLO, A.R.; BARBARINI, N. Reestruturação produtiva no setor bancário brasileiro e sofrimento dos caixas executivos: um estudo de caso. Psicologia \& Sociedade; 14 (1): 103122 ; jan./jun.2002.

Morgan, G. Imagens da organização. São Paulo: Atlas, 1996.

Moulin, M.G.B. Trabalho, gênero e saúde mental: modos de inserção da mulher no trabalho bancário. Rio de Janeiro: Universidade Federal do Rio de Janeiro, 1996 (Dissertação de mestrado em Psicossociologia de Comunidades e Ecologia Social). 
Sobre os impactos da organização do trabalho bancário na saúde mental dos trabalhadores. In: Simpósio SaÚde Mental E Trabalho Bancário. Anais... Vitória: Gráfica Santo Antônio, 1997.

OffE, C. Trabalho: categoria-chave na sociologia? In: Revista Brasileira de Ciências Sociais, São Paulo, V.10, n.4, jun. 1989.

PAuChant, T.C. A psicologia do self na empresa: uma prespectiva kohutiana. In CHANLAT, J.F. (org) O indivíduo na organização: dimensões esquecidas. V.III. São Paulo: Atlas, 1996.

RIBEIRO, M.S. Fragilidade financeira e ajuste do sistema bancário comercial brasileiro pós-Plano Real. Belo Horizonte: Centro de Pesquisas e Pós-Graduação em Administração da Faculdade de Ciências Econômicas da Universidade Federal de Minas Gerais, 1999 (Dissertação de Mestrado em Administração).

SAntos, M. Por uma outra globalização: do pensamento único à consciência universal. 9 . ed. Rio de Janeiro: Record, 2002.

SEGNINI, L.R.P. Mulheres no trabalho bancário: difusão tecnológica, qualificação e relações de gênero. São Paulo: Editora da Universidade de são Paulo, 1998.

SEnNet, R. A corrosão do caráter: as conseqüências pessoais do trabalho no novo capitalismo. Tradução Marcos Santarrita. 8. ed. Rio de Janeiro: Record, 2004.

SilvA, A.C.A. Estresse, estressores e qualidade de vida de bancários: um estudo exploratório com uma amostra de funcionários do Banco do Brasil. Campinas: Pontifícia Universidade Católica, 1992 (Dissertação de Mestrado em Psicologia).

Silva, T.T. da. A produção social da identidade e da diferença. In: Silva, T.T. (org) Identidade e diferença: a perspectiva dos estudos culturais. 2. ed. Petrópolis, RJ: Vozes 2000.

SPINK, M.J.; FreZZA, R.M. Práticas discursivas e produção dos sentidos: a perspective da Psicologia Social. In Spink, M.J. (org) Práticas Discursivas e produção de sentidos no cotidiano: aproximações teóricas e metodológicas. São Paulo: Cortez, 1999.

StevanAto, L. A. Um estudo sobre a construção da identidade social dos profissionais 
de e-business. São Paulo: FEA/USP, 2004. (Tese de Doutorado em Administração).

TEIXEIRA, P.T.F. A individualidade humana na obra marxiana de 1843 a 1848. in. Ensaios Ad Hominem - N.1, Tomo 1- Marxismo. São Paulo: Estudos e Edições Ad Hominem, 1999.

ToSE, M.G.L.S. Teletrabalho: a prática do trabalho a organização subjetiva dos seus agentes. São Paulo: PUC São Paulo, 2005.(Tese de Doutorado em Ciências Sociais).

Toulmin, S. Cosmópolis: the hidden agenda of modernity. New York: The Free Press, 1990 apud FLICK, U. Uma introdução à Pesquisa Qualitativa. 2. ed. Tradução Sandra Netz. Porto Alegre: Bookman, 2004.

VAlle, P.R.A. Automação bancária e seus impactos sobre o trabalho: o caso de um grande banco privado nacional. Belo Horizonte: Centro de Pesquisas e Pós-Graduação em Administração da Faculdade de Ciências Econômicas da Universidade Federal de Minas Gerais, 1995 (Dissertação de Mestrado em Economia).

VASCONCELOS, I.F.G; VASCONCELOS, F.C. Gestão de recursos humanos e identidade social: um estudo crítico. Revista de Administração de Empresas - RAE. São Paulo: v. 42, n. 1, p. 64-78, Jan/Mar, 2002.

Veloso, H.M et al. As transformações no mundo do trabalho. In: Pimenta, S.M. (org) Recursos Humanos: uma dimensão estratégica. Belo Horizonte: UFMG/FACE/CEPEAD, 1999.

Veloso, H. M. O que o coração sente mesmo quando os olhos não vêem: levantamento e análise dos agentes estressores do trabalho bancário. Belo Horizonte: Centro de PósGraduação e Pesquisa em Administração da Faculdade de Ciências Econômicas da Universidade Federal de Minas Gerais, 2000 (Dissertação de Mestrado em Administração).

WoODWARD, K. Identidade e diferença: uma introdução teórica e conceitual. In: SILVA, T.T. (org) Identidade e diferença: a perspectiva dos estudos culturais. 2. ed. Petrópolis, RJ: Vozes 2000. 


\section{APÊNDICE A - ROTEIRO DE ENTREVISTA}

Começar a entrevista explicando a natureza do trabalho acadêmico e garantindo o sigilo das respostas do entrevistado. Explicar que a conversa será gravada apenas por questões de praticidade e para não atrasar o processo de entrevista.

1. Aspectos Introdutórios (objetivo da pergunta: situar o indivíduo dentro do seu quadro de referência pessoal)

1.1. Data da Entrevista

1.2. Nome completo

1.3. Banco em que trabalha

1.4. Idade

1.5. Formação

1.6. Estado Civil? Filhos?

1.7. Quando você não está trabalhando o que gosta de fazer?

1.8. Você gosta de fazer compras? O que você gosta de comprar? O que você sente quando está comprando? (Aprofundar diálogo)

1.9. Quando as pessoas perguntam quem é você, o que utiliza como referência para explicar quem é?

1.10 O que você diria para seu filho se ele perguntasse quem é você?

2. Identificação funcional do entrevistado (objetivo da pergunta: avaliar o tempo de contato do entrevistado com a organização, com a agência, com a profisssão; situar o funcionário na estrutura da empresa; avaliar o grau de familiaridade com a tarefa executada)

2.1. Há quantos anos você trabalha neste banco?

2.2. E nesta agência?

2.3. Já trabalhou em outros bancos? (detalhar, caso sim) 
2.4. Tempo total como bancário (não precisa necessariamente perguntar)

2.5. Qual é o Cargo/Função que você executa?

2.6. Há quanto tempo neste cargo?

3. Visão do próprio trabalho (objetivo da pergunta: compreender a execução das tarefas no banco; avaliar os relacionamentos horizontais e verticais do funcionário; avaliar o nível de contato com o consumidor)

3.1. Descreva o trabalho que realiza no banco, falando de suas funções, tarefas e obrigações. (Modus operandi).

3.2. Na execução de seu trabalho você tem muito contato com outros funcionários ou com seus superiores?

3.3. E com os consumidores, você tem muito contato com eles?

4. Consciência das transformações do trabalho (objetivo da pergunta: avaliar se o funcionário possui uma visão de que seu trabalho tem sofrido alterações e quais as perspectivas para o seu futuro profissional)

4.1. Como você vê a sua profissão no passado? (traçar paralelo com o presente)

4.2. E no futuro?

4.3. Qual é a principal transformação que você percebeu no trabalho bancário?

5. Sobre o trabalho (objetivo da pergunta: descobrir como o indivíduo vê a sua relação com o trabalho)

5.1. O que um bancário faz e o que diferencia o trabalho de um bancário de outras profissões?

5.2. Você se sente bancário?

5.3. Como você se sente ao trabalhar dentro do banco?

5.4. O que você gostaria de mudar em seu trabalho?

5.5. Você se identifica com o trabalho que faz? 


\section{Imagem da organização atual}

6.1. Qual a importância que a organização tem na sua vida?

6.2. Você acha que o Banco (nome do banco) afeta na definição de quem você é?

6.3. O que diferencia, na sua opinião, o trabalho dentro do Banco (nome do Banco) daquele de outras instituições?

6.4. Com quais aspectos da organização você se identifica?

6.5. Entre trabalhar como bancário em outra organização (diferente da que trabalha atualmente) e trabalhar no banco em outra profissão (não sendo bancário), em qual situação você se identifica mais?

\section{Concepção da Categoria Profissional}

7.1. Como você vê os bancários como uma categoria profissional?

7.2. Você se identifica com esta categoria profissional?

\section{Tipificações}

8.1. Gostaria que você falasse das seguintes pessoas, descrevendo quem são elas e como você as caracteriza:

8.1.1. Você como consumidor (eu-consumidor)

8.1.2. Você como bancário (eu-trabalhador)

8.1.3. O consumidor (outro-consumidor)

8.1.4. O colega de trabalho bancário (outro-trabalhador)

8.2. O que é ser “consumidor” na sua percepção?

8.3. Qual é a importância do consumidor?

8.4. Como é a sua relação com o consumidor?

8.5. Como o consumidor interfere na realização de seu trabalho? 
8.6. Compare o consumidor e você dentro da organização, descrevendo as principais diferenças e semelhanças.

8.7. Você sente que o indivíduo consumidor é mais importante do que o indivíduo bancário?

8.8. Compare duas situações: você como trabalhador x você como consumidor. Quais as diferenças e semelhanças que você percebe nas duas situações?

8.9. Você prefere ser consumidor ou ser bancário?

\section{Descrições}

9.1. O que representa o trabalho para você?

9.2. Como você acha que o trabalho afeta na definição de quem é você?

9.3. O que representa o consumo para você?

9.4. Como você acha que o consumo afeta na definição de quem é você?

9.5. O que representa o consumidor para você?

9.6. Como você acha que o consumidor afeta na definição de quem é você?

9.7. Você acha que ao consumir você consegue expressar a sua individualidade, mostrando quem é a partir do que consome e de que forma consome?

\section{Finalização}

Você gostaria de fazer algum outro comentário ou sugestão? Há algum ponto que tenha sido esquecido, mas que você acha que é importante salientar?Agradecer a participação. Desligar gravador e perguntar se há alguma dúvida. 


\section{APÊNDICE B - QUADROS DE ANÁLISE DO ROTEIRO DE ENTREVISTA}

Quadro 13 - Quadro de análise do roteiro de pesquisa por categoria de análise

\begin{tabular}{|ll|}
\hline Pergunta do Roteiro & Categorias de análise \\
\hline$(1.1),(1.2),(1.3),(1.4),(1.5),(1.6),(1.7)$ & Caracterização da população \\
$(2.1),(2.2),(2.3),(2.4),(2.5),(2.6),(3.1),(3.2)$, & Identificação funcional e caracterização do trabalho \\
$(3.3),(5.10,(6 . .3)$ & \\
$(1.8),(8.1 .1),(8.1 .3),(8.2),(8.3),(8.4),(8.5),(8.6)$, & Ser Consumidor \\
$(8.7),(8.8),(8.9),(9.3),(9.4),(9.5),(9.6),(9.7)$ & \\
$(1.7),(1.10),(3.1),(4),.(4.2),(5.1),(5.3),(5.4)$, & Ser Trabalhador \\
$(5.5),(7.1),(8.1 .2),(8.1 .4),(9.1),(9.2)$ & \\
$(5.3),(5.4),(6.1),(7.1),(9.1)$, & Valor-trabalho \\
$(1.8),(8.2),(8.3),(8.4),(8.5),(8.7),(9.3),(9.5)$ & Valor-consumo \\
$(4.1),(4.2),(4.3)$ & Consciência das transformações do trabalho \\
$(1.9),(1.10)$ & Expressão de Identidade \\
$(5.2),(5.5),(6.2),(6.4),(6.5),(7.2)(8.1 .4),(9.2)$ & Expressão de Identidade-trabalho \\
$(8.1 .1),(8.1 .3),(9.4),(9.6),(9.7)$ & Expressão de Identidade-consumo \\
$(8.6),(8.8),(8.9)$ & Expressão de Identidade-consumo-trabalho \\
\hline
\end{tabular}

Fonte: do autor 


\section{APÊNDICE C - ANÁLISE DOS DADOS INDIVIDUAIS DOS ENTREVISTADOS}

\begin{tabular}{|c|c|c|}
\hline & \multicolumn{2}{|c|}{ Tipificações } \\
\hline & Trabalhador & Consumidor \\
\hline $\mathrm{Eu}$ & Eu - trabalhador & Eu - consumidor \\
\hline & $\begin{array}{c}\text { Orgulho } \\
\text { Valorização } \\
\text { Faço dentro das normas } \\
\text { Pessoa correta } \\
\text { Precisa ser psicólogo } \\
\text { Ser condescendente } \\
\text { Dependo do consumidor }\end{array}$ & $\begin{array}{c}\text { Sou controlada } \\
\text { Sou tranqüila } \\
\text { Não sou compulsiva } \\
\text { Gosto de qualidade } \\
\text { Exijo bom atendimento }\end{array}$ \\
\hline Outro & Colega de trabalho & Consumidor \\
\hline & $\begin{array}{c}\text { Pessoa que ajuda } \\
\text { Parceiros } \\
\text { Pessoa importante para desenvolver o trabalho } \\
\text { Classe unida } \\
\text { Poderia ser mais unida } \\
\text { Falta integração entre os bancos } \\
\end{array}$ & $\begin{array}{c}\text { É quem paga o meu salário } \\
\text { Parte fundamental } \\
\text { Sem ele não desenvolvo o meu trabalho }\end{array}$ \\
\hline
\end{tabular}

\begin{tabular}{|c|c|c|}
\hline & $\begin{array}{c}\text { Sentir valorizado } \\
\text { Sentir orgulho } \\
\text { Ser psicólogo } \\
\text { Fazer dentro das normas } \\
\text { Ser correta } \\
\text { Ser condescendente } \\
\text { Depender do consumidor } \\
\text { Ajudar } \\
\text { Ser parceiro }\end{array}$ & $\begin{array}{c}\text { Ser tranqüilo } \\
\text { Ser compulsivo } \\
\text { Ser controlado } \\
\text { Gostar de qualidade } \\
\text { Exigir bom atendimento } \\
\text { Pagar o salário dos outros }\end{array}$ \\
\hline $\begin{array}{c}\text { Referências } \\
\text { Identitárias } \\
\text { Predominantes }\end{array}$ & $\begin{array}{l}\text { O que é ser } \\
\text { Bancário }\end{array}$ & O que é ser Consumidor \\
\hline
\end{tabular}

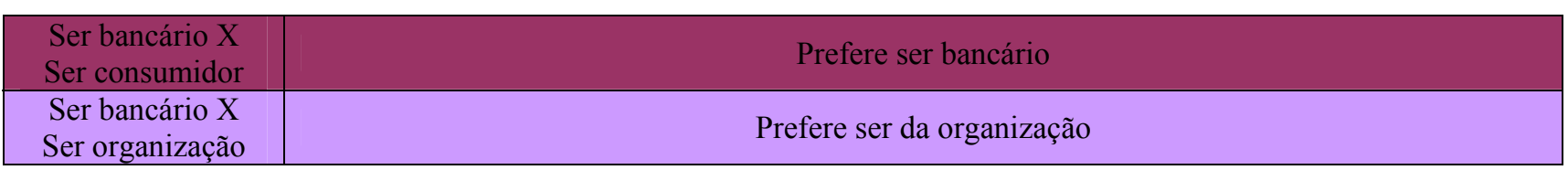

\begin{tabular}{|c|c|}
\hline Referências sociais & Características pessoais \\
\hline Variável Estudada & Identidade Social \\
\hline
\end{tabular}

\begin{tabular}{|c|c|c|c|c|}
\cline { 2 - 5 } \multicolumn{1}{c|}{} & Valor & Sentido & Valor & Sentido \\
\cline { 2 - 5 } \multicolumn{1}{c|}{} & $\begin{array}{c}\text { Econômico } \\
\text { Moral }\end{array}$ & $\begin{array}{c}\text { Positivo } \\
\text { Positivo } \\
\text { Econômico } \\
\text { Social }\end{array}$ & $\begin{array}{c}\text { Positivo } \\
\text { Positivo } \\
\text { Positivo }\end{array}$ \\
\hline $\begin{array}{c}\text { Descrições feitas } \\
\text { pelos bancários }\end{array}$ & \multicolumn{2}{|c|}{ Descrição do Trabalho } & Descrição do Consumo e do Consumidor \\
\hline
\end{tabular}

\section{Figura 4 - $\quad$ Análise dos dados do Entrevistado: 01}

Fonte: Dados de pesquisa 


\begin{tabular}{|c|c|c|}
\hline & \multicolumn{2}{|c|}{ Tipificações } \\
\hline & Trabalhador & Consumidor \\
\hline \multirow[t]{2}{*}{$\mathrm{Eu}$} & Eu - trabalhador & Eu - consumidor \\
\hline & $\begin{array}{c}\text { Adoro trabalhar no banco } \\
\text { Gosto de fazer direito } \\
\text { Tem que saber filtrar os tipos de cliente }\end{array}$ & $\begin{array}{c}\text { Gosto de comprar } \\
\text { Gosto de ter as coisas } \\
\text { Apavorado para comprar } \\
\text { Impulsivo }\end{array}$ \\
\hline \multirow[t]{2}{*}{ Outro } & Colega de trabalho & Consumidor \\
\hline & $\begin{array}{c}\text { Tem alguns que são amigos mesmo } \\
\text { Gosto do pessoal que trabalha aqui } \\
\text { São sinceros } \\
\text { Não vejo falsidade } \\
\text { Classe desunida } \\
\text { Privado x Público }\end{array}$ & $\begin{array}{c}\text { Tem vários tipos } \\
\text { Tem uns que a gente pode confiar } \\
\text { Tem cliente que xinga } \\
\text { Se acha Deus }\end{array}$ \\
\hline
\end{tabular}

\begin{tabular}{|c|c|c|}
\hline & $\begin{array}{c}\text { Fazer direito } \\
\text { Gostar de Trabalhar no Banco } \\
\text { Ser amigo } \\
\text { Saber filtrar os tipos de cliente } \\
\text { Ser sincero } \\
\text { Ser desunido }\end{array}$ & $\begin{array}{c}\text { Gostar de Comprar } \\
\text { Ter coisas } \\
\text { Ser impulsivo } \\
\text { Ser confiável } \\
\text { Xingar } \\
\text { Se achar Deus } \\
\end{array}$ \\
\hline $\begin{array}{l}\text { Referências } \\
\text { Identitárias } \\
\text { Predominantes }\end{array}$ & $\begin{array}{l}\text { O que é ser } \\
\text { Bancário }\end{array}$ & O que é ser Consumidor \\
\hline
\end{tabular}

\begin{tabular}{|c|c|} 
Ser bancário X & Prefere ser consumidor \\
Ser consumidor & Prefere ser da organização \\
\hline Ser bancário X & \\
Ser organização & \\
\hline
\end{tabular}

\begin{tabular}{|c|c|c|c|c|}
\hline & Valor & Sentido & Valor & Sentido \\
\hline & $\begin{array}{c}\text { Pessoal } \\
\text { Moral }\end{array}$ & $\begin{array}{l}\text { Positivo } \\
\text { Positivo }\end{array}$ & $\begin{array}{c}\text { Pessoal } \\
\text { Econômica }\end{array}$ & $\begin{array}{l}\text { Positivo } \\
\text { Positivo }\end{array}$ \\
\hline $\begin{array}{c}\text { Descrições feitas } \\
\text { pelos bancários }\end{array}$ & \multicolumn{2}{|c|}{ Descrição do Trabalho } & \multicolumn{2}{|c|}{ Descrição do Consumo e do Consumidor } \\
\hline
\end{tabular}

Figura 5 - $\quad$ Análise dos dados do Entrevistado: 02

Fonte: Dados de pesquisa 


\begin{tabular}{|c|c|c|}
\hline & \multicolumn{2}{|c|}{ Tipificações } \\
\hline & Trabalhador & Consumidor \\
\hline \multirow[t]{10}{*}{$\mathrm{Eu}$} & Eu - trabalhador & Eu - consumidor \\
\hline & Realização & Sou consumista \\
\hline & Consultor de negócios & Gosto de novidade \\
\hline & Atendimento & Exigente \\
\hline & Relacionamento & Se me atendeu bem acaba me ganhando \\
\hline & Lidar com gente & Sou esclarecido \\
\hline & Venda de um serviço & Exige como é exigido \\
\hline & Sou $90 \%$ trabalho & \\
\hline & Gosta de ser transparente & \\
\hline & Sou fácil de lidar & \\
\hline \multirow[t]{5}{*}{ Outro } & Colega de trabalho & Consumidor \\
\hline & Equipe boa & O cliente está mais consciente \\
\hline & Categoria unida na ora de buscar benefício & Mais informado \\
\hline & Concorrentes & Pesquisa mais \\
\hline & & Quer mais tempo para conversar \\
\hline
\end{tabular}

\begin{tabular}{|c|c|c|}
\hline & $\begin{array}{c}\text { Sentir realizado } \\
\text { Ser consultor } \\
\text { Atender } \\
\text { Relacionar } \\
\text { Lidar com gente } \\
\text { Vender serviço } \\
\text { Ser transparente } \\
\text { Ser fácil de lidar } \\
\text { Ser concorrente }\end{array}$ & $\begin{array}{c}\text { Ser consumista } \\
\text { Gostar de novidade } \\
\text { Ser exigente } \\
\text { Ser esclarecido } \\
\text { Exigir } \\
\text { Ser mais consciente } \\
\text { Pesquisar mais } \\
\text { Querer mais tempo para conversar }\end{array}$ \\
\hline $\begin{array}{c}\text { Referências } \\
\text { Identitárias } \\
\text { Predominantes }\end{array}$ & $\begin{array}{c}\text { O que é ser } \\
\text { Bancário }\end{array}$ & O que é ser Consumidor \\
\hline
\end{tabular}

\begin{tabular}{|c|c|}
\hline Ser bancário X & Prefere ser bancário \\
Ser consumidor & Prefere ser da organização \\
\hline Ser bancário X & \\
Ser organização & \\
\hline
\end{tabular}

\begin{tabular}{|c|c|}
\hline Referências sociais & Organização \\
\hline Variável Estudada & Identidade Social \\
\hline
\end{tabular}

\begin{tabular}{|c|c|c|c|c|}
\cline { 2 - 5 } \multicolumn{1}{c|}{} & Valor & Sentido & Valor & Sentido \\
\cline { 2 - 5 } \multicolumn{1}{c|}{} & $\begin{array}{c}\text { Pessoal } \\
\text { Moral }\end{array}$ & $\begin{array}{c}\text { Positivo } \\
\text { Positivo }\end{array}$ & $\begin{array}{c}\text { Pessoal } \\
\text { Econômico }\end{array}$ & Positivo \\
\hline $\begin{array}{c}\text { Descrições feitas } \\
\text { pelos bancários }\end{array}$ & \multicolumn{2}{|c|}{ Descrição do Trabalho } & Descrição do Consumo e do Consumidor \\
\hline
\end{tabular}

Figura 6 - Análise dos dados do Entrevistado: 03

Fonte: Dados de pesquisa 


\begin{tabular}{|c|c|c|}
\hline & \multicolumn{2}{|c|}{ Tipificações } \\
\hline & Trabalhador & Consumidor \\
\hline \multirow[t]{2}{*}{$\mathrm{Eu}$} & Eu - trabalhador & Eu - consumidor \\
\hline & $\begin{array}{c}\text { Menor status } \\
\text { Pressão } \\
\text { Empresta dinheiro } \\
\text { Relacionamento } \\
\text { Muito responsável } \\
\text { Dependo do consumidor }\end{array}$ & $\begin{array}{c}\text { Exigir direitos } \\
\text { Ter obrigações } \\
\text { Tenho que frear como consumidor }\end{array}$ \\
\hline \multirow[t]{2}{*}{ Outro } & Colega de trabalho & Consumidor \\
\hline & $\begin{array}{c}\text { É o parceiro } \\
\text { Muitos colegas } \\
\text { A gente tenta trabalhar em parceria } \\
\text { Existem ovelhas desgarradas } \\
\text { São unidos }\end{array}$ & $\begin{array}{c}\text { É quem determina o mercado } \\
\text { É quem dita as regras } \\
\text { É ele que vai determinar se eu vou trabalhar } \\
\text { nesse ramo mais algum tempo ou não }\end{array}$ \\
\hline
\end{tabular}

\begin{tabular}{|c|c|c|}
\hline & $\begin{array}{c}\text { Ter menos status } \\
\text { Ser pressionado } \\
\text { Emprestar dinheiro } \\
\text { Relacionar } \\
\text { Ser responsável } \\
\text { Ser parceiro } \\
\text { Ser unido }\end{array}$ & $\begin{array}{c}\text { Exigir direitos } \\
\text { Ter obrigações } \\
\text { Determinar o mercado } \\
\text { Ditar as regras } \\
\text { Determinar quem trabalha }\end{array}$ \\
\hline $\begin{array}{l}\text { Referências } \\
\text { Identitárias } \\
\text { Predominantes }\end{array}$ & $\begin{array}{l}\text { O que é ser } \\
\text { Bancário }\end{array}$ & O que é ser Consumidor \\
\hline
\end{tabular}

Ser bancário X

Ser consumidor

Ser bancário X

Ser organização

\section{Prefere ser bancário}

Depende da função

Referências sociais $\quad$ Organização

Variável Estudada $\quad$ Identidade Social

\begin{tabular}{|c|c|c|c|c|}
\cline { 2 - 5 } \multicolumn{1}{c|}{} & Valor & Sentido & Valor & Sentido \\
\cline { 2 - 5 } & Econômico & Positivo & Psicológico & Positivo \\
& & & Moral & Positivo \\
& & & Político & Positivo \\
& & & Econômico & Positivo \\
\hline $\begin{array}{c}\text { Descrições feitas } \\
\text { pelos bancários }\end{array}$ & \multicolumn{2}{|c|}{ Descrição do Trabalho } & Descrição do Consumo e do Consumidor \\
\hline
\end{tabular}

Figura 7 - $\quad$ Análise dos dados do Entrevistado: 04

Fonte: Dados de pesquisa 


\begin{tabular}{|c|c|c|}
\hline & \multicolumn{2}{|c|}{ Tipificações } \\
\hline & Trabalhador & Consumidor \\
\hline $\mathrm{Eu}$ & Eu - trabalhador & Eu - consumidor \\
\hline & $\begin{array}{c}\text { Vendedor } \\
\text { Pró-atividade } \\
\text { Frustração } \\
150 \% \text { da minha meta } \\
\text { Visar resultados }\end{array}$ & $\begin{array}{c}\text { Bom senso } \\
\text { Comprar sem exageros } \\
\text { Compro o necessário } \\
\text { Consumidor agressivo }\end{array}$ \\
\hline Outro & Colega de trabalho & Consumidor \\
\hline & $\begin{array}{l}\text { Não tem mais sensibilidade } \\
\text { Quer travar uma guerra } \\
\text { Ele quer crescer } \\
\text { Sem força política }\end{array}$ & $\begin{array}{c}\text { O cliente é muito exigente } \\
\text { Evoluído } \\
\text { Consciente }\end{array}$ \\
\hline
\end{tabular}

\begin{tabular}{|c|c|c|}
\hline & $\begin{array}{c}\text { Vender } \\
\text { Ser pró-ativo } \\
\text { Sentir frustração } \\
\text { Visar resultados } \\
\text { Não ser sensível } \\
\text { Travar uma guerra } \\
\text { Crescer } \\
\text { Não ter força política }\end{array}$ & $\begin{array}{c}\text { Ter bom senso } \\
\text { Comprar sem exageros } \\
\text { Comprar o necessário } \\
\text { Ser agressivo } \\
\text { Ser exigente } \\
\text { Ser evoluído } \\
\text { Ser consciente }\end{array}$ \\
\hline $\begin{array}{l}\text { Referências } \\
\text { Identitárias } \\
\text { Predominantes }\end{array}$ & $\begin{array}{l}\text { O que é ser } \\
\text { Bancário }\end{array}$ & O que é ser Consumidor \\
\hline
\end{tabular}

\begin{tabular}{|c|c|}
\hline Ser bancário X & Prefere ser consumidor \\
Ser consumidor & Prefere ser da organização \\
\hline Ser bancário X & \\
Ser organização & \\
\hline
\end{tabular}

\begin{tabular}{|c|c|}
\hline Referências sociais & Organização \\
\hline Variável Estudada & Identidade Social \\
\hline
\end{tabular}

\begin{tabular}{|c|c|c|c|c|}
\cline { 2 - 5 } \multicolumn{1}{c|}{} & Valor & Sentido & Valor & Sentido \\
\cline { 2 - 5 } & $\begin{array}{c}\text { Econômico } \\
\text { Social } \\
\text { Pessoal }\end{array}$ & $\begin{array}{c}\text { Positivo } \\
\text { Negativo } \\
\text { Positivo }\end{array}$ & Econsoal & Positivo \\
\hline $\begin{array}{c}\text { Descrições feitas } \\
\text { pelos bancários }\end{array}$ & \multicolumn{2}{|c|}{ Descrição do Trabalho } & Descrição do Consumo e do Consumidor \\
\hline
\end{tabular}

Figura 8 - $\quad$ Análise dos dados do Entrevistado: 05

Fonte: Dados de pesquisa 


\begin{tabular}{|c|c|c|}
\hline & \multicolumn{2}{|c|}{ Tipificações } \\
\hline & Trabalhador & Consumidor \\
\hline $\mathrm{Eu}$ & Eu - trabalhador & Eu - consumidor \\
\hline & $\begin{array}{c}\text { Perdeu status } \\
\text { Relaciona com pessoas } \\
\text { Vende produtos } \\
\text { Satisfaz o cliente } \\
\text { Tem que dar resultado } \\
\text { Não sei o que eu seria se não tivesse trabalho } \\
\text { Me identifico com vários clientes }\end{array}$ & $\begin{array}{c}\text { Buscar o que precisa } \\
\text { Impulsiva } \\
\text { Compra mais do que precisa } \\
\text { Se identifica com o cliente chato }\end{array}$ \\
\hline Outro & Colega de trabalho & Consumidor \\
\hline & $\begin{array}{l}\text { Nem todo mundo se dá bem com a profissão } \\
\text { Muitos não queriam estar em bancos }\end{array}$ & $\begin{array}{l}\text { O cliente hoje é fundamental } \\
\text { Tem que tratar bem } \\
\text { Hoje tudo depende do cliente }\end{array}$ \\
\hline
\end{tabular}

\begin{tabular}{|c|c|c|}
\hline & & \\
\hline & $\begin{array}{c}\text { Perder status } \\
\text { Relacionar com pessoas } \\
\text { Vender produtos } \\
\text { Satisfazer o cliente } \\
\text { Dar resultado } \\
\text { Não se dar bem com a profissão } \\
\text { Não querer estar em bancos } \\
\text { Se identificar com o cliente }\end{array}$ & $\begin{array}{c}\text { Buscar o que precisa } \\
\text { Ser impulsiva } \\
\text { Comprar mais do que precisa } \\
\text { Ser chato } \\
\text { Ser fundamental } \\
\text { Ser bem tratado }\end{array}$ \\
\hline $\begin{array}{c}\text { Referências } \\
\text { Identitárias } \\
\text { Predominantes }\end{array}$ & $\begin{array}{c}\text { O que é ser } \\
\text { Bancário }\end{array}$ & O que é ser Consumidor \\
\hline
\end{tabular}

Ser bancário X

Ser consumidor

Ser bancário X

Ser organização
Prefere ser bancário

Prefere ser da organização

\begin{tabular}{|c|c|c|c|c|}
\cline { 2 - 5 } \multicolumn{1}{c|}{} & Valor & Sentido & Valor & Sentido \\
\cline { 2 - 5 } & Pessoal & Positivo & Pessoal & Positivo \\
Econômico & Positivo & Econômico & Positivo \\
Social & Negativo & Decial & Descrição do Consumo e do Consumidor \\
\hline $\begin{array}{c}\text { Descrições feitas } \\
\text { pelos bancários }\end{array}$ & \multicolumn{2}{c|}{ Descrição do Trabalho } & Cono \\
\hline
\end{tabular}

Figura 9 -

Análise dos dados do Entrevistado: 06

Fonte: Dados de pesquisa 


\begin{tabular}{|c|c|c|}
\hline & \multicolumn{2}{|c|}{ Tipificações } \\
\hline & Trabalhador & Consumidor \\
\hline \multirow[t]{2}{*}{$\mathrm{Eu}$} & Eu - trabalhador & Eu - consumidor \\
\hline & $\begin{array}{c}\text { Atualizado } \\
\text { Ajuda as pessoas a realizar sonhos } \\
\text { Bom profissional } \\
\text { Segue as normas do banco } \\
\text { É você poder estar comprando } \\
\text { Sei ouvir } \\
\text { Fico quietinho } \\
\text { Trata o cliente como gostaria de ser tratado }\end{array}$ & $\begin{array}{c}\text { Gosto de consumir } \\
\text { Não tem preocupação com o futuro }\end{array}$ \\
\hline \multirow[t]{2}{*}{ Outro } & Colega de trabalho & Consumidor \\
\hline & $\begin{array}{c}\text { Amigos confidentes } \\
\text { Desunida } \\
\text { Se contrapõem entre organizações diferentes } \\
\text { Vê os funcionários do banco do Brasil e da } \\
\text { caixa como diferentes } \\
\text { Dispersa } \\
\text { Não sabe a força que tem }\end{array}$ & $\begin{array}{l}\text { O cliente é tudo } \\
\text { É a alma do negócio }\end{array}$ \\
\hline
\end{tabular}

\begin{tabular}{|c|c|c|}
\hline & $\begin{array}{c}\text { Ser atualizado } \\
\text { Ajudar as pessoas } \\
\text { Seguir normas } \\
\text { Poder comprar } \\
\text { Ouvir } \\
\text { Ficar quietinho } \\
\text { Tratar o cliente como gosta de ser tratado } \\
\text { Ser desunido } \\
\text { Ser disperso } \\
\text { Não saber a força que tem } \\
\end{array}$ & $\begin{array}{c}\text { Gostar de consumir } \\
\text { Não ter preocupação com futuro } \\
\text { Ser tudo } \\
\text { Ser a alma do negócio }\end{array}$ \\
\hline $\begin{array}{c}\text { Referências } \\
\text { Identitárias } \\
\text { Predominantes }\end{array}$ & $\begin{array}{c}\text { O que é ser } \\
\text { Bancário }\end{array}$ & O que é ser Consumidor \\
\hline
\end{tabular}

\begin{tabular}{|c|c|}
\hline Ser bancário X & Prefere ser bancário \\
Ser consumidor & Prefere ser da organização \\
\hline Ser bancário X & \\
Ser organização & \\
\hline
\end{tabular}

\begin{tabular}{|c|c|}
\hline Referências sociais & Referência a características pessoais \\
\hline Variável Estudada & Identidade Social \\
\hline
\end{tabular}

\begin{tabular}{|c|c|c|c|c|}
\cline { 2 - 4 } \multicolumn{1}{c|}{} & Valor & Sentido & Valor & Sentido \\
\cline { 2 - 5 } & $\begin{array}{c}\text { Pessoal } \\
\text { Social } \\
\text { Econômico } \\
\text { Moral }\end{array}$ & $\begin{array}{l}\text { Positivo } \\
\text { Positivo } \\
\text { Positivo } \\
\text { Positivo }\end{array}$ & Econômico & Positivo \\
\hline $\begin{array}{c}\text { Descrições feitas } \\
\text { pelos bancários }\end{array}$ & \multicolumn{2}{|c|}{ Descrição do Trabalho } & Descrição do Consumo e do Consumidor \\
\hline
\end{tabular}

Figura 10 - $\quad$ Análise dos dados do Entrevistado: 07

Fonte: Dados de pesquisa 


\begin{tabular}{|c|c|c|}
\hline & \multicolumn{2}{|c|}{ Tipificações } \\
\hline & Trabalhador & Consumidor \\
\hline \multirow[t]{2}{*}{$\mathrm{Eu}$} & Eu - trabalhador & Eu - consumidor \\
\hline & $\begin{array}{c}\text { Competitivo } \\
\text { Atende o cliente } \\
\text { Mais organizado } \\
\text { Trabalho é tudo para mim } \\
\text { Respeito } \\
\text { Você consegue tudo } \\
\text { É menos exigente }\end{array}$ & $\begin{array}{c}\text { Tornou-se uma pessoa controlada } \\
\text { Exigente } \\
\text { Quer clareza e confiança } \\
\text { É instruída } \\
\text { Posso dar o grito }\end{array}$ \\
\hline \multirow[t]{2}{*}{ Outro } & Colega de trabalho & Consumidor \\
\hline & $\begin{array}{l}\text { Já foram mais humildes } \\
\text { Estão distantes } \\
\text { Medo de perder o emprego }\end{array}$ & $\begin{array}{l}\text { Reclama sem conhecimento do que tem direito } \\
\text { É um casamento com o cliente }\end{array}$ \\
\hline
\end{tabular}

\begin{tabular}{|c|c|c|}
\hline & $\begin{array}{c}\text { Ser competitivo } \\
\text { Atender o cliente } \\
\text { Ser mais organizado } \\
\text { Ser respeitado } \\
\text { Conseguir tudo } \\
\text { Ser menos exigente } \\
\text { Não ser humilde } \\
\text { Ter medo de perder o emprego }\end{array}$ & $\begin{array}{c}\text { Ser controlado } \\
\text { Exigir } \\
\text { Querer clareza e confiança } \\
\text { Ser instruído } \\
\text { Poder dar o grito } \\
\text { Reclamar sem conhecer os direitos }\end{array}$ \\
\hline $\begin{array}{c}\text { Referências } \\
\text { Identitárias } \\
\text { Predominantes }\end{array}$ & $\begin{array}{c}\text { O que é ser } \\
\text { Bancário }\end{array}$ & O que é ser Consumidor \\
\hline
\end{tabular}

Ser bancário X

Ser consumidor

Ser bancário X

Ser organização

\section{Prefere ser bancário}

Prefere ser da organização

Referências sociais $\quad$ Organização

Variável Estudada $\quad$ Identidade Social

\begin{tabular}{|c|c|c|c|c|}
\hline & Valor & Sentido & Valor & Sentido \\
\hline & $\begin{array}{c}\text { Pessoal } \\
\text { Social } \\
\text { Econômico } \\
\text { Moral }\end{array}$ & $\begin{array}{l}\text { Positivo } \\
\text { Positivo } \\
\text { Positivo } \\
\text { Positivo }\end{array}$ & $\begin{array}{c}\text { Pessoal } \\
\text { Econômico }\end{array}$ & $\begin{array}{l}\text { Negativo } \\
\text { Positivo }\end{array}$ \\
\hline $\begin{array}{l}\text { Descrições feitas } \\
\text { pelos bancários }\end{array}$ & \multicolumn{2}{|c|}{ Descrição do Trabalho } & \multicolumn{2}{|c|}{ Descrição do Consumo e do Consumido } \\
\hline
\end{tabular}

Figura 11 - $\quad$ Análise dos dados do Entrevistado: 08

Fonte: Dados de pesquisa 


\begin{tabular}{|c|c|c|}
\hline & \multicolumn{2}{|c|}{ Tipificações } \\
\hline & Trabalhador & Consumidor \\
\hline \multirow[t]{2}{*}{$\mathrm{Eu}$} & Eu - trabalhador & Eu - consumidor \\
\hline & $\begin{array}{l}\text { De tudo um pouco } \\
\text { Atende o cliente } \\
\text { Gosta do que faz } \\
\text { Representa tudo } \\
\text { Auto-estima }\end{array}$ & Gosta de consumir para desestressar \\
\hline \multirow[t]{2}{*}{ Outro } & Colega de trabalho & Consumidor \\
\hline & $\begin{array}{l}\text { Tem que ser companheiro } \\
\text { Compreensivo } \\
\text { Alguns vão passar por cima } \\
\text { Estressados } \\
\text { Trabalha como se fosse máquina }\end{array}$ & Tem que estar satisfeito com o banco \\
\hline
\end{tabular}

\begin{tabular}{|c|c|c|}
\hline & $\begin{array}{c}\text { Ser de tudo um pouco } \\
\text { Atender o cliente } \\
\text { Gostar do que faz } \\
\text { Ter auto-estima } \\
\text { Ser companheiro } \\
\text { Ser compreensivo } \\
\text { Passar por cima } \\
\text { Ser estressado } \\
\text { Trabalhar como máquina }\end{array}$ & $\begin{array}{c}\text { Gostar de consumir para desestressar } \\
\text { Ser satisfeito }\end{array}$ \\
\hline $\begin{array}{c}\text { Referências } \\
\text { Identitárias } \\
\text { Predominantes }\end{array}$ & $\begin{array}{l}\text { O que é ser } \\
\text { Bancário }\end{array}$ & O que é ser Consumidor \\
\hline
\end{tabular}

\begin{tabular}{|c|c|}
\hline Ser bancário X & Prefere ser bancário \\
Ser consumidor & Prefere ser da organização \\
\hline Ser bancário X & \\
Ser organização & \\
\hline
\end{tabular}

\begin{tabular}{|c|c|}
\hline Referências sociais & Família \\
\hline Variável Estudada & Identidade Social \\
\hline
\end{tabular}

\begin{tabular}{|c|c|c|c|c|}
\cline { 2 - 5 } \multicolumn{1}{c|}{} & Valor & Sentido & Valor & Sentido \\
\cline { 2 - 5 } \multicolumn{1}{c|}{} & $\begin{array}{c}\text { Econômico } \\
\text { Pessoal }\end{array}$ & $\begin{array}{c}\text { Positivo } \\
\text { Contraditório }\end{array}$ & $\begin{array}{c}\text { Pessoal } \\
\text { Econômico }\end{array}$ & Positivo \\
\hline $\begin{array}{c}\text { Descrições feitas } \\
\text { pelos bancários }\end{array}$ & \multicolumn{2}{|c|}{ Descrição do Trabalho } & Descrição do Consumo e do Consumidor \\
\hline
\end{tabular}

Figura 12 - $\quad$ Análise dos dados do Entrevistado: 09

Fonte: Dados de pesquisa 


\begin{tabular}{|c|c|c|}
\hline & \multicolumn{2}{|c|}{ Tipificações } \\
\hline & Trabalhador & Consumidor \\
\hline $\mathrm{Eu}$ & Eu - trabalhador & Eu - consumidor \\
\hline & $\begin{array}{c}\text { Faz negócio com o cliente } \\
\text { Dedicado } \\
\text { Comprometido } \\
\text { Subsistência } \\
\text { Trabalho que goste de fazer } \\
\text { Sou bom de relacionamento com os clientes } \\
\text { Sou decidido }\end{array}$ & $\begin{array}{c}\text { Compro o que tenho necessidade } \\
\text { Realizações } \\
\text { Prezo pela qualidade } \\
\text { Não sou passivo } \\
\text { Se realiza fazendo compras } \\
\text { Insegura para comprar }\end{array}$ \\
\hline Outro & Colega de trabalho & Consumidor \\
\hline & $\begin{array}{c}\text { Companheiro } \\
\text { Passa mais tempo aqui do que com a família } \\
\text { Já foram unidos como categoria } \\
\text { Não tem mais a estabilidade }\end{array}$ & A razão de estar ali \\
\hline
\end{tabular}

\begin{tabular}{|c|c|c|}
\hline & & \\
\hline & $\begin{array}{c}\text { Fazer negócio com o cliente } \\
\text { Ser dedicado } \\
\text { Ser comprometido } \\
\text { Gostar do trabalho que faz } \\
\text { Ser bom de relacionamento } \\
\text { Ser decidido } \\
\text { Ser companheiro } \\
\text { Passar mais tempo no banco do que com a } \\
\text { família } \\
\text { Não ter estabilidade }\end{array}$ & $\begin{array}{c}\text { Comprar o que tem necessidade } \\
\text { Realizar-se } \\
\text { Prezar pela qualidade } \\
\text { Não ser passivo } \\
\text { Ser inseguro para comprar } \\
\text { Não comprar para sua subsistência } \\
\text { Ser a razão de alguém estar ali }\end{array}$ \\
\hline $\begin{array}{c}\text { Referências } \\
\text { Identitárias } \\
\text { Predominantes }\end{array}$ & $\begin{array}{l}\text { O que é ser } \\
\text { Bancário }\end{array}$ & O que é ser Consumidor \\
\hline
\end{tabular}

\begin{tabular}{|c|c|}
\hline $\begin{array}{l}\text { Ser bancário X } \\
\text { Ser consumidor }\end{array}$ & Prefere ser bancário \\
\hline $\begin{array}{c}\text { Ser bancário X } \\
\text { Ser organização }\end{array}$ & efere ser da organização \\
\hline
\end{tabular}

\begin{tabular}{|c|c|}
\hline Referências sociais & Família \\
\hline Variável Estudada & Identidade Social \\
\hline
\end{tabular}

\begin{tabular}{|c|c|c|c|c|}
\cline { 2 - 5 } \multicolumn{1}{c|}{} & Valor & Sentido & Valor & Sentido \\
\cline { 2 - 5 } \multicolumn{1}{c|}{} & $\begin{array}{c}\text { Econômico } \\
\text { Pessoal }\end{array}$ & $\begin{array}{c}\text { Positivo } \\
\text { Contraditório }\end{array}$ & $\begin{array}{c}\text { Pessoal } \\
\text { Econômico }\end{array}$ & $\begin{array}{c}\text { Contraditório } \\
\text { Positivo }\end{array}$ \\
\hline $\begin{array}{c}\text { Descrições feitas } \\
\text { pelos bancários }\end{array}$ & \multicolumn{2}{|c|}{ Descrição do Trabalho } & \multicolumn{2}{c|}{ Descrição do Consumo e do Consumidor } \\
\hline
\end{tabular}

Figura 13 -

Análise dos dados do Entrevistado: 10

Fonte: Dados de pesquisa 


\begin{tabular}{|c|c|c|}
\hline & \multicolumn{2}{|c|}{ Tipificações } \\
\hline & Trabalhador & Consumidor \\
\hline $\mathrm{Eu}$ & Eu - trabalhador & Eu - consumidor \\
\hline & $\begin{array}{c}\text { Ajuda a pessoa a cuidar do dinheiro } \\
\text { Trabalha direitinho } \\
\text { Faz com qualidade } \\
\text { Não tenho preguiça de trabalhar } \\
\text { Gosta de trabalhar } \\
\text { Paciente }\end{array}$ & $\begin{array}{l}\text { Compro coisa boa } \\
\text { O que gosta não tem preço } \\
\text { Indeciso }\end{array}$ \\
\hline Outro & Colega de trabalho & Consumidor \\
\hline & $\begin{array}{c}\text { Tem ciúmes } \\
\text { Não vejo muito unido }\end{array}$ & $\begin{array}{c}\text { Muito bom } \\
\text { Nervoso } \\
\text { Tem uns que falam absurdos }\end{array}$ \\
\hline
\end{tabular}

\begin{tabular}{|c|c|c|}
\hline & $\begin{array}{c}\text { Ajudar a cuidar do dinheiro da pessoa } \\
\text { Trabalhar direitinho } \\
\text { Fazer com qualidade } \\
\text { Não ter preguiça de trabalhar } \\
\text { Gostar de trabalhar } \\
\text { Ser paciente } \\
\text { Ter ciúmes } \\
\text { Não ser unido }\end{array}$ & $\begin{array}{l}\text { Comprar coisas boas } \\
\text { Ser indeciso } \\
\text { Ser muito bom } \\
\text { Ser nervoso } \\
\text { Falar absurdos }\end{array}$ \\
\hline $\begin{array}{c}\text { Referências } \\
\text { Identitárias } \\
\text { Predominantes }\end{array}$ & $\begin{array}{l}\text { O que é ser } \\
\text { Bancário }\end{array}$ & O que é ser Consumidor \\
\hline
\end{tabular}

\begin{tabular}{|c|c|}
\hline Ser bancário X & Prefere ser bancário \\
Ser consumidor & Prefere ser da organização \\
\hline Ser bancário X & \\
Ser organização & \\
\hline
\end{tabular}

\begin{tabular}{|c|c|}
\hline Referências sociais & Organização \\
\hline Variável Estudada & Identidade Social \\
\hline
\end{tabular}

\begin{tabular}{|c|c|c|c|c|}
\cline { 2 - 5 } \multicolumn{1}{c|}{} & Valor & Sentido & Valor & Pessoal \\
\cline { 2 - 5 } & $\begin{array}{c}\text { Psicológico } \\
\text { Econômico } \\
\text { Moral }\end{array}$ & $\begin{array}{l}\text { Positivo } \\
\text { Positivo } \\
\text { Positivo }\end{array}$ & Positivo \\
\hline $\begin{array}{c}\text { Descrições feitas } \\
\text { pelos bancários }\end{array}$ & \multicolumn{2}{|c|}{ Descrição do Trabalho } & Descrição do Consumo e do Consumidor \\
\hline
\end{tabular}

Figura 14 - $\quad$ Análise dos dados do Entrevistado: 11

Fonte: Dados de pesquisa 


\begin{tabular}{|c|c|c|}
\hline & \multicolumn{2}{|c|}{ Tipificações } \\
\hline & Trabalhador & Consumidor \\
\hline \multirow[t]{2}{*}{$\mathrm{Eu}$} & Eu - trabalhador & Eu - consumidor \\
\hline & $\begin{array}{c}\text { Competitivo } \\
\text { Mais responsabilidade } \\
\text { Vende dinheiro } \\
\text { Relacionamento } \\
\text { Dedicado } \\
\text { Sente feliz } \\
\text { Satisfação muito grande } \\
\text { Uma realização } \\
\text { Justifica meu consumo } \\
\text { Coloco sentimento na relação } \\
\text { Dedicado }\end{array}$ & $\begin{array}{c}\text { Consumista } \\
\text { Consumo o que preciso } \\
\text { Extrapolo } \\
\text { É um prazer } \\
\text { Sou bom consumidor } \\
\text { Gostaria de me ter como cliente }\end{array}$ \\
\hline \multirow[t]{2}{*}{ Outro } & Colega de trabalho & Consumidor \\
\hline & $\begin{array}{c}\text { Um parceiro } \\
\text { Tem que ser legal } \\
\text { É um pessoal unido } \\
\text { Classe unida } \\
\text { Tem uma grande força } \\
\text { Muito bem definida }\end{array}$ & $\begin{array}{c}\text { Elo da cadeia mais importante } \\
\text { Muito mais exigente que antes } \\
\text { Mais conhecimento de seus direitos } \\
\text { Não é fiel } \\
\text { Você perde ele facinho }\end{array}$ \\
\hline
\end{tabular}

\begin{tabular}{|c|c|c|}
\hline & $\begin{array}{c}\text { Ser competitivo } \\
\text { Ter responsabilidade } \\
\text { Vender dinheiro } \\
\text { Relacionar } \\
\text { Ser dedicado } \\
\text { Ser feliz } \\
\text { Ter satisfação } \\
\text { Realizar-se } \\
\text { Justificar o consumo } \\
\text { Colocar sentimento } \\
\text { Ser unido } \\
\text { Ter uma grande força }\end{array}$ & $\begin{array}{c}\text { Ser consumista } \\
\text { Consumir o que precisa } \\
\text { Extrapolar } \\
\text { Sentir prazer } \\
\text { Ser elo mais importante da cadeia } \\
\text { Ser mais exigente } \\
\text { Conhecer mais os direitos } \\
\text { Não ser fiel }\end{array}$ \\
\hline $\begin{array}{c}\text { Referências } \\
\text { Identitárias } \\
\text { Predominantes }\end{array}$ & $\begin{array}{l}\text { O que é ser } \\
\text { Bancário }\end{array}$ & O que é ser Consumidor \\
\hline
\end{tabular}

\begin{tabular}{|c|c|}
\hline Ser bancário X & Prefere ser bancário \\
Ser consumidor & Prefere ser da organização \\
\hline Ser bancário X & \\
Ser organização & \\
\hline
\end{tabular}

\begin{tabular}{|c|c|}
\hline Referências sociais & Organização \\
\hline Variável Estudada & Identidade Social \\
\hline
\end{tabular}

\begin{tabular}{|c|c|c|c|c|}
\hline & Valor & Sentido & Valor & Sentido \\
\hline & Pessoal & Positivo & $\begin{array}{c}\text { Pessoal } \\
\text { Econômico }\end{array}$ & $\begin{array}{l}\text { Positivo } \\
\text { Positivo } \\
\end{array}$ \\
\hline $\begin{array}{c}\text { Descrições feitas } \\
\text { pelos bancários }\end{array}$ & \multicolumn{2}{|c|}{ Descrição do Trabalho } & \multicolumn{2}{|c|}{ Descrição do Consumo e do Consumidor } \\
\hline
\end{tabular}

Figura 15 -

Análise dos dados do Entrevistado: 12

Fonte: Dados de pesquisa 


\begin{tabular}{|c|c|c|}
\hline & \multicolumn{2}{|c|}{ Tipificações } \\
\hline & Trabalhador & Consumidor \\
\hline \multirow[t]{2}{*}{$\mathrm{Eu}$} & Eu - trabalhador & Eu - consumidor \\
\hline & $\begin{array}{c}\text { Menos status } \\
\text { Vende } \\
\text { Satisfação da minha vida }\end{array}$ & $\begin{array}{l}\text { Tenho necessidades } \\
\text { Estou controlado } \\
\text { Sou cliente do banco }\end{array}$ \\
\hline \multirow[t]{2}{*}{ Outro } & Colega de trabalho & Consumidor \\
\hline & $\begin{array}{c}\text { Trabalho em equipe } \\
\text { Busca ajudar um ao outro } \\
\text { Categoria estressada } \\
\text { Pessoas que correm atrás }\end{array}$ & $\begin{array}{l}\text { Personagem principal da questão bancária } \\
\text { Ele é que me ajuda a conseguir tudo isso }\end{array}$ \\
\hline
\end{tabular}

\begin{tabular}{|c|c|c|}
\hline & $\begin{array}{c}\text { Ter menos status } \\
\text { Vender } \\
\text { Trabalhar em equipe } \\
\text { Ajudar o outro } \\
\text { Ser estressado } \\
\text { Correr atrás } \\
\end{array}$ & $\begin{array}{l}\text { Ter necessidades } \\
\text { Ser controlado } \\
\text { Ser personagem principal } \\
\text { Ajudar a conseguir tudo }\end{array}$ \\
\hline $\begin{array}{c}\text { Referências } \\
\text { Identitárias } \\
\text { Predominantes } \\
\end{array}$ & $\begin{array}{l}\text { O que é ser } \\
\text { Bancário }\end{array}$ & O que é ser Consumidor \\
\hline
\end{tabular}

\begin{tabular}{|c|c|}
\hline Ser bancário X & Prefere ser consumidor \\
Ser consumidor & Prefere ser da organização \\
\hline Ser bancário X & \\
Ser organização & \\
\hline
\end{tabular}

\begin{tabular}{|c|c|}
\hline Referências sociais & Organização \\
\hline Variável Estudada & Identidade Social \\
\hline
\end{tabular}

\begin{tabular}{|c|c|c|c|c|}
\cline { 2 - 4 } \multicolumn{1}{c|}{} & Valor & Sentido & Valor & Pessoal \\
\cline { 2 - 5 } & $\begin{array}{c}\text { Pessoal } \\
\text { Econômico } \\
\text { Moral }\end{array}$ & $\begin{array}{l}\text { Positivo } \\
\text { Positivo } \\
\text { Positivo }\end{array}$ & Positivo \\
\hline $\begin{array}{c}\text { Descrições feitas } \\
\text { pelos bancários }\end{array}$ & \multicolumn{2}{|c|}{ Descriçãão do Trabalho Consumo e do Consumidor } \\
\hline
\end{tabular}

Figura 16 - $\quad$ Análise dos dados do Entrevistado: 13

Fonte: Dados de pesquisa 


\begin{tabular}{|c|c|c|}
\hline & \multicolumn{2}{|c|}{ Tipificações } \\
\hline & Trabalhador & Consumidor \\
\hline \multirow{2}{*}{$\mathrm{Eu}$} & Eu - trabalhador & $\mathrm{Eu}$ - consumidor \\
\hline & $\begin{array}{c}\text { Vender } \\
\text { Ter persuasão } \\
\text { Dedicada } \\
\text { Concorda com o sistema } \\
\text { É um vencedor } \\
\text { Passo uma imagem do eu } \\
\text { Quer qualidade }\end{array}$ & $\begin{array}{c}\text { Sou crítico } \\
\text { Faço pesquisas antes de comprar } \\
\text { Sou criteriosa } \\
\text { Não compro no impulso } \\
\text { Quer qualidade }\end{array}$ \\
\hline \multirow[t]{2}{*}{ Outro } & Colega de trabalho & Consumidor \\
\hline & $\begin{array}{c}\text { Tem que gostar de trabalhar e trabalhar em } \\
\text { equipe } \\
\text { Categoria rebelde } \\
\text { Novatos rebeldes } \\
\text { Categoria que sofre junto com o povo } \\
\text { Categoria que tem que sobreviver } \\
\text { Tende a reduzir } \\
\text { Sabe que tem que se investir para manter no } \\
\text { ramo }\end{array}$ & $\begin{array}{c}\text { Tem mudado } \\
\text { Cada vez mais exigente } \\
\text { Cada vez mais sabendo das coisas }\end{array}$ \\
\hline
\end{tabular}

\begin{tabular}{|c|c|c|}
\hline & $\begin{array}{c}\text { Vender } \\
\text { Ter persuasão } \\
\text { Ser dedicado } \\
\text { Concordar com o sistema } \\
\text { Ser vencedor } \\
\text { Passar uma imagem de si } \\
\text { Querer qualidade } \\
\text { Gostar de trabalhar em equipe } \\
\text { Ser rebelde } \\
\text { Sofrer junto com o povo } \\
\text { Ter que sobreviver } \\
\text { Ter que investir em si }\end{array}$ & $\begin{array}{c}\text { Ser crítico } \\
\text { Fazer pesquisas antes de comprar } \\
\text { Ser criteriosa } \\
\text { Não comprar no impulso } \\
\text { Querer qualidade } \\
\text { Mudar } \\
\text { Ser mais exigente } \\
\text { Saber mais das coisas }\end{array}$ \\
\hline $\begin{array}{c}\text { Referências } \\
\text { Identitárias } \\
\text { Predominantes }\end{array}$ & $\begin{array}{l}\text { O que é ser } \\
\text { Bancário }\end{array}$ & O que é ser Consumidor \\
\hline
\end{tabular}

\begin{tabular}{|c|c|}
\hline Ser bancário X & Prefere ser consumidor \\
Ser consumidor & Prefere ser da organização \\
\hline Ser bancário X & \\
Ser organização & \\
\hline
\end{tabular}

Referências sociais $\quad$ Família

Variável Estudada Identidade Social

\begin{tabular}{|c|c|c|c|c|}
\cline { 2 - 5 } \multicolumn{1}{c|}{} & Valor & Sentido & Valor & Sentido \\
\cline { 2 - 5 } & $\begin{array}{c}\text { Pessoal } \\
\text { Econômico } \\
\text { Moral }\end{array}$ & $\begin{array}{c}\text { Contraditório } \\
\text { Positivo } \\
\text { Positivo }\end{array}$ & $\begin{array}{c}\text { Pessoal } \\
\text { Econômico } \\
\text { Positivo }\end{array}$ \\
\hline $\begin{array}{c}\text { Descrições feitas } \\
\text { pelos bancários }\end{array}$ & \multicolumn{2}{c|}{ Descrição do Trabalho } & Descrição do Consumo e do Consumidor \\
\hline
\end{tabular}

Figura 17 - $\quad$ Análise dos dados do Entrevistado: 14

Fonte: Dados de pesquisa 


\begin{tabular}{|c|c|c|}
\hline & \multicolumn{2}{|c|}{ Tipificações } \\
\hline & Trabalhador & Consumidor \\
\hline \multirow[t]{2}{*}{$\mathrm{Eu}$} & Eu - trabalhador & Eu - consumidor \\
\hline & $\begin{array}{c}\text { Metas } \\
\text { Psicólogo } \\
\text { Administrador } \\
\text { Exercício ilegal da profissão } \\
\text { Ajuda as pessoas } \\
\text { A favor do cliente } \\
\text { Não nasci para ser dondoca } \\
\text { O trabalho faz a gente se sentir completo } \\
\text { Tenta ser igual ao consumidor }\end{array}$ & $\begin{array}{l}\text { Fujo ao consumir } \\
\text { Tento me controlar } \\
\text { Compulsiva } \\
\text { Sou exigente }\end{array}$ \\
\hline \multirow[t]{2}{*}{ Outro } & Colega de trabalho & Consumidor \\
\hline & $\begin{array}{c}\text { Está no mesmo barco } \\
\text { Tem as mesmas metas } \\
\text { As mesmas pressões } \\
\text { Não vejo como um número } \\
\text { Cambada de gente medíocre } \\
\text { Bancário qualquer um pode ser } \\
\text { Estagnada naquilo }\end{array}$ & $\begin{array}{c}\text { Sem informação } \\
\text { O cliente tirano e o que precisa de ajuda }\end{array}$ \\
\hline
\end{tabular}

\begin{tabular}{|c|c|c|}
\hline & $\begin{array}{c}\text { Ter metas } \\
\text { Ser psicólogo } \\
\text { Ser administrador } \\
\text { Ajudar pessoas } \\
\text { Ser a favor do cliente } \\
\text { Não ser dondoca } \\
\text { Se sentir completo } \\
\text { Ser igual ao consumidor } \\
\text { Ser pressionado } \\
\text { Ser medíocre } \\
\text { Ser estagnado } \\
\end{array}$ & $\begin{array}{c}\text { Fugir } \\
\text { Tentar se controlar } \\
\text { Ser compulsivo } \\
\text { Ser exigente } \\
\text { Ser tirano } \\
\text { Precisar de ajuda }\end{array}$ \\
\hline $\begin{array}{c}\text { Referências } \\
\text { Identitárias } \\
\text { Predominantes }\end{array}$ & $\begin{array}{c}\text { O que é ser } \\
\text { Bancário }\end{array}$ & O que é ser Consumidor \\
\hline
\end{tabular}

\begin{tabular}{|c|c|}
\hline $\begin{array}{l}\text { Ser bancário X } \\
\text { Ser consumidor }\end{array}$ & Prefere ser consumidor \\
\hline $\begin{array}{c}\text { Ser bancário X } \\
\text { Ser organização }\end{array}$ & Prefere ser da organização \\
\hline
\end{tabular}

\begin{tabular}{l|l} 
Referências sociais & Referência a características pessoais
\end{tabular}

\begin{tabular}{|c|c}
\hline Variável Estudada & Identidade Social \\
\hline
\end{tabular}

\begin{tabular}{|c|c|c|c|c|}
\cline { 2 - 4 } \multicolumn{1}{c|}{} & Valor & Sentido & Valor & Sentido \\
\cline { 2 - 4 } & Pessoal & Negativo & Pessoal & Pocial \\
& Social & Negativo & Positivo \\
& Moral & Positivo & Positivo \\
\hline Econômico & \\
\hline pescrições feitas & \multicolumn{2}{c|}{ Descrição do Trabalho } & Descrição do Consumo e do Consumidor \\
\hline
\end{tabular}

Figura 18 - Análise dos dados do Entrevistado: 15

Fonte: Dados de pesquisa 


\begin{tabular}{|c|c|c|}
\hline & \multicolumn{2}{|c|}{ Tipificações } \\
\hline & Trabalhador & Consumidor \\
\hline $\mathrm{Eu}$ & Eu - trabalhador & Eu - consumidor \\
\hline & $\begin{array}{c}\text { Tem cobranças } \\
\text { Consultor financeiro } \\
\text { Presta serviço } \\
\text { Satisfeito } \\
\text { Não deixo dúvidas para o cliente } \\
\text { Realização } \\
\text { Ter alguma coisa para encher meu dia } \\
\text { Sou profissional } \\
\text { Procura o melhor } \\
\text { Dói quando não consegue satisfazer o cliente }\end{array}$ & $\begin{array}{l}\text { Busca complementar-se } \\
\text { Sou muito exigente } \\
\text { Procuro satisfação completa } \\
\text { Sou formiga de supermercados }\end{array}$ \\
\hline Outro & Colega de trabalho & Consumidor \\
\hline & $\begin{array}{l}\text { Totalmente desunido } \\
\text { Concorrência }\end{array}$ & Ele é muito exigente \\
\hline
\end{tabular}

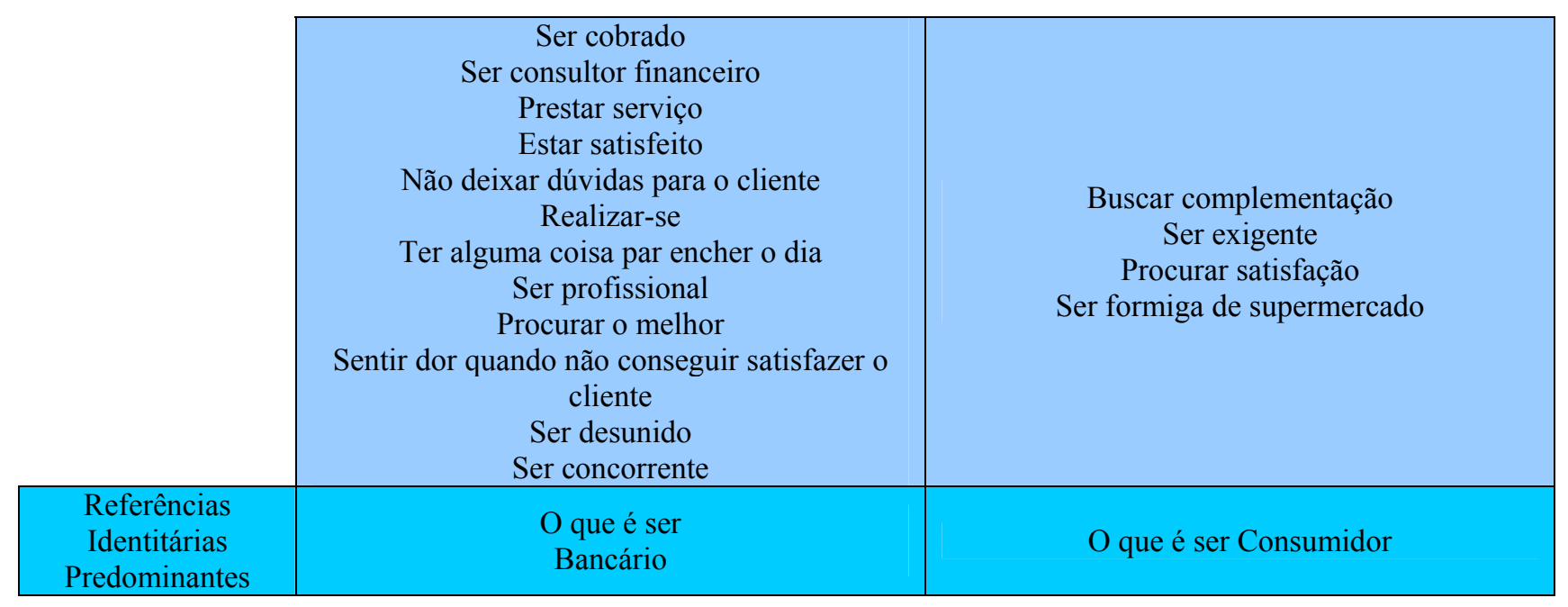

\begin{tabular}{|c|c|}
\hline Ser bancário X & Prefere ser bancário \\
Ser consumidor & Prefere ser da organização \\
\hline Ser bancário X & \\
Ser organização & \\
\hline
\end{tabular}

Referências sociais $\quad$ Referência a características pessoais

$\begin{array}{ll}\text { Variável Estudada } & \text { Identidade Social }\end{array}$

\begin{tabular}{|c|c|c|c|c|}
\hline & Valor & Sentido & Valor & Sentido \\
\hline & Pessoal & Positivo & $\begin{array}{c}\text { Pessoal } \\
\text { Econômico }\end{array}$ & $\begin{array}{l}\text { Positivo } \\
\text { Positivo }\end{array}$ \\
\hline $\begin{array}{l}\text { Descrições feitas } \\
\text { pelos bancários }\end{array}$ & \multicolumn{2}{|c|}{ Descrição do Trabalho } & \multicolumn{2}{|c|}{ Descrição do Consumo e do Consumidor } \\
\hline
\end{tabular}

Figura 19 - $\quad$ Análise dos dados do Entrevistado: 16

Fonte: Dados de pesquisa 


\begin{tabular}{|c|c|c|}
\hline & \multicolumn{2}{|c|}{ Tipificações } \\
\hline & Trabalhador & Consumidor \\
\hline $\mathrm{Eu}$ & Eu - trabalhador & Eu - consumidor \\
\hline & $\begin{array}{c}\text { Vende } \\
\text { Cobro demais de mim } \\
\text { Importante } \\
\text { Necessário pelo dinheiro } \\
\text { Ocupa a cabeça da gente } \\
\text { Trabalho para consumir } \\
\text { Procura deixar o consumidor satisfeito }\end{array}$ & $\begin{array}{l}\text { Sou exigente } \\
\text { Passei a ser inteligente } \\
\text { Vou pesquisar } \\
\text { Vou querer ser melhor } \\
\text { É insatisfeita }\end{array}$ \\
\hline Outro & Colega de trabalho & Consumidor \\
\hline & $\begin{array}{c}\text { Me dou bem com todos } \\
\text { Categoria estressada } \\
\text { Todo mundo bem parecido, todo mundo } \\
\text { desesperado, muita correria, só fala em banco e } \\
\text { em dinheiro }\end{array}$ & Imprevisível \\
\hline
\end{tabular}

\begin{tabular}{|c|c|c|}
\hline & $\begin{array}{c}\text { Vender } \\
\text { Cobrar-se demais } \\
\text { Ser importante } \\
\text { Ocupar a cabeça } \\
\text { Trabalhar para consumir } \\
\text { Deixar o consumidor satisfeito } \\
\text { Dar-se bem com todos os colegas } \\
\text { Ser estressado } \\
\text { Ser parecido com colegas } \\
\text { Ser desesperado } \\
\text { Correr muito } \\
\text { Só falar em Banco e dinheiro }\end{array}$ & $\begin{array}{c}\text { Ser exigente } \\
\text { Ser inteligente } \\
\text { Pesquisar } \\
\text { Querer ser melhor } \\
\text { Ser insatisfeito } \\
\text { Ser impaciente } \\
\text { Brigar } \\
\text { Ser imprevisível }\end{array}$ \\
\hline $\begin{array}{c}\text { Referências } \\
\text { Identitárias } \\
\text { Predominantes }\end{array}$ & $\begin{array}{c}\text { O que é ser } \\
\text { Bancário }\end{array}$ & O que é ser Consumidor \\
\hline
\end{tabular}

\begin{tabular}{|c|c|}
\hline Ser bancário X & Prefere ser bancário \\
Ser consumidor & Prefere ser da organização \\
\hline Ser bancário X & Ser organização
\end{tabular}

\begin{tabular}{|c|c|}
\hline Referências sociais & Organização \\
\hline Variável Estudada & Identidade Social \\
\hline
\end{tabular}

\begin{tabular}{|c|c|c|c|c|}
\cline { 2 - 5 } \multicolumn{1}{c|}{} & Valor & Sentido & Valor & Sentido \\
\cline { 2 - 5 } & $\begin{array}{c}\text { Pessoal } \\
\text { Econômico }\end{array}$ & $\begin{array}{c}\text { Contraditório } \\
\text { Positivo } \\
\text { Econômico } \\
\text { Social }\end{array}$ & $\begin{array}{c}\text { Positivo } \\
\text { Positivo } \\
\text { Positivo }\end{array}$ \\
\hline $\begin{array}{c}\text { Descrições feitas } \\
\text { pelos bancários }\end{array}$ & \multicolumn{2}{|c|}{ Descrição do Trabalho } & Descrição do Consumo e do Consumidor \\
\hline
\end{tabular}

Figura 20 - $\quad$ Análise dos dados do Entrevistado: 17

Fonte: Dados de pesquisa 


\begin{tabular}{|c|c|c|}
\hline & \multicolumn{2}{|c|}{ Tipificações } \\
\hline & Trabalhador & Consumidor \\
\hline \multirow[t]{2}{*}{$\mathrm{Eu}$} & Eu - trabalhador & Eu - consumidor \\
\hline & $\begin{array}{c}\text { Atende clientes } \\
\text { Vende } \\
\text { Profissional } \\
\text { Representa minha vida } \\
\text { Trato como eu gosto de ser tratado } \\
\text { Atendo como cliente }\end{array}$ & $\begin{array}{c}\text { Amo consumir } \\
\text { Sou mais consumista } \\
\text { Consumidor compulsivo }\end{array}$ \\
\hline \multirow[t]{2}{*}{ Outro } & Colega de trabalho & Consumidor \\
\hline & $\begin{array}{c}\text { Trabalho em equipe } \\
\text { Categoria melhor hoje em dia }\end{array}$ & Exigente \\
\hline
\end{tabular}

\begin{tabular}{|c|c|c|}
\hline & $\begin{array}{c}\text { Atender clientes } \\
\text { Vender } \\
\text { Ser profissional } \\
\text { Tratar como gosta de ser tratado } \\
\text { Atender clientes } \\
\text { Trabalhar em equipe } \\
\end{array}$ & $\begin{array}{c}\text { Amar consumir } \\
\text { Ser consumista } \\
\text { Ser compulsivo } \\
\text { Ser exigente }\end{array}$ \\
\hline $\begin{array}{c}\text { Referências } \\
\text { Identitárias } \\
\text { Predominantes }\end{array}$ & $\begin{array}{l}\text { O que é ser } \\
\text { Bancário }\end{array}$ & O que é ser Consumidor \\
\hline
\end{tabular}

Ser bancário X

Ser consumidor

Ser bancário X

Ser organização

\section{Prefere ser bancário}

Prefere ser da organização

\begin{tabular}{l|l} 
Referências sociais & Organização
\end{tabular}

Variável Estudada $\quad$ Identidade Social

\begin{tabular}{|c|c|c|c|c|}
\cline { 2 - 5 } \multicolumn{1}{c|}{} & Valor & Sentido & Valor & Sentido \\
\cline { 2 - 5 } & $\begin{array}{c}\text { Pessoal } \\
\text { Econômico }\end{array}$ & $\begin{array}{c}\text { Positivo } \\
\text { Positivo }\end{array}$ & $\begin{array}{c}\text { Pessoal } \\
\text { Social }\end{array}$ & Positivo \\
\hline $\begin{array}{c}\text { Descrições feitas } \\
\text { pelos bancários }\end{array}$ & \multicolumn{2}{c|}{ Descrição do Trabalho } & Descrição do Consumo e do Consumidor \\
\hline
\end{tabular}

Figura 21 - $\quad$ Análise dos dados do Entrevistado: 18

Fonte: Dados de pesquisa 


\begin{tabular}{|c|c|c|}
\cline { 2 - 3 } \multicolumn{1}{c|}{} & \multicolumn{2}{c|}{ Tipificações } \\
\cline { 2 - 3 } \multicolumn{1}{c|}{} & Trabalhador & Consumidor \\
\hline \multirow{2}{*}{$\mathrm{Eu}$} & Eu - trabalhador & Eu - consumidor \\
\hline & Vendedor & Mau cliente \\
Status & Não gosto de gastar \\
\hline Outro & Não sou estritamente profissional \\
& Estabeleço vínculo pessoal com consumidor & Consumidor \\
\hline & Colega de trabalho & Alguém a se atender \\
& Necessidade de se tornar amigos \\
& Começando a ficar unidos & Satisfazer as necessidades \\
& Os funcionários de outros bancos se interagiam \\
& muito mais & \\
\cline { 2 - 3 } & &
\end{tabular}

\begin{tabular}{|c|c|c|}
\hline & $\begin{array}{c}\text { Vender } \\
\text { Ter status } \\
\text { Ser estritamente profissional } \\
\text { Estabelecer vínculo com consumidor } \\
\text { Ser amigo dos colegas }\end{array}$ & $\begin{array}{c}\text { Ser mau cliente } \\
\text { Não gostar de gastar } \\
\text { Satisfazer as necessidades }\end{array}$ \\
\hline $\begin{array}{c}\text { Referências } \\
\text { Identitárias } \\
\text { Predominantes }\end{array}$ & $\begin{array}{c}\text { O que é ser } \\
\text { Bancário }\end{array}$ & O que é ser Consumidor \\
\hline
\end{tabular}

\begin{tabular}{|c|c|}
\hline Ser bancário X & Prefere ser os dois \\
Ser consumidor & Prefere ser da organização \\
\hline Ser bancário X & \\
Ser organização & \\
\hline
\end{tabular}

\begin{tabular}{|c|c|}
\hline Referências sociais & Organização \\
\hline Variável Estudada & Identidade Social \\
\hline
\end{tabular}

\begin{tabular}{|c|c|c|c|c|}
\cline { 2 - 5 } \multicolumn{1}{c|}{} & Valor & Sentido & Valor & Sentido \\
\cline { 2 - 5 } & $\begin{array}{c}\text { Pessoal } \\
\text { Econômico } \\
\text { Moral }\end{array}$ & $\begin{array}{c}\text { Positivo } \\
\text { Positivo } \\
\text { Positivo }\end{array}$ & Econôl & Positivo \\
\hline $\begin{array}{c}\text { Descrições feitas } \\
\text { pelos bancários }\end{array}$ & \multicolumn{2}{|c|}{ Descrição do Trabalho } & Descrição do Consumo e do Consumidor \\
\hline
\end{tabular}

Figura 22 - $\quad$ Análise dos dados do Entrevistado: 19

Fonte: Dados de pesquisa 


\begin{tabular}{|c|c|c|}
\hline & \multicolumn{2}{|c|}{ Tipificações } \\
\hline & Trabalhador & Consumidor \\
\hline \multirow[t]{2}{*}{$\mathrm{Eu}$} & Eu - trabalhador & Eu - consumidor \\
\hline & $\begin{array}{c}\text { Concorrência } \\
\text { Bater metas } \\
\text { Sou exigente comigo mesmo } \\
\text { Não gosto de coisas erradas } \\
\text { Vejo o interesse do banco } \\
\text { Me coloco no lugar do cliente }\end{array}$ & $\begin{array}{l}\text { Consumo para passar o tempo } \\
\text { O que não tem necessidade } \\
\text { Sou exigente } \\
\text { Não aceito erros } \\
\text { Gosto das coisas bem feitas } \\
\text { Reclamo }\end{array}$ \\
\hline \multirow[t]{2}{*}{ Outro } & Colega de trabalho & Consumidor \\
\hline & $\begin{array}{c}\text { Tem uns que não estão nem aí } \\
\text { Estão despreocupados } \\
\text { Profissão normal } \\
\text { Classe média } \\
\text { Status } \\
\end{array}$ & $\begin{array}{c}\text { Tem cliente exigente } \\
\text { Tem cliente calmo e tem cliente apavorado }\end{array}$ \\
\hline
\end{tabular}

\begin{tabular}{|c|c|c|}
\cline { 2 - 3 } \multicolumn{1}{c|}{} & $\begin{array}{c}\text { Ser concorrente } \\
\text { Ter pior salário } \\
\text { Bater metas }\end{array}$ & $\begin{array}{c}\text { Consumir para passar o tempo } \\
\text { Consumir o que não tem necessidade } \\
\text { Ser exigente }\end{array}$ \\
& $\begin{array}{c}\text { Ser exigente consigo mesmo } \\
\text { Não gostar de coisas erradas } \\
\text { Ver o interesse do banco } \\
\text { Colocar-se no lugar do cliente }\end{array}$ \\
\hline Referências & O que é ser & $\begin{array}{c}\text { Reclamar } \\
\text { Gostar das coisas bem feitas }\end{array}$ \\
Identitárias & Bancário & Ser calmo ou ser apavorado \\
Predominantes & O que é ser Consumidor \\
\hline
\end{tabular}

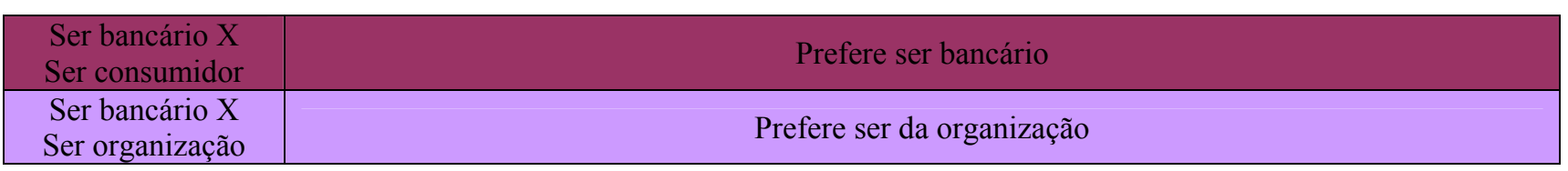

\begin{tabular}{c|c}
\hline Referências sociais & Organização \\
\hline Variável Fstudada & Identidade Soci
\end{tabular}

\begin{tabular}{|c|c|c|c|c|}
\hline & Valor & Sentido & Valor & Sentido \\
\hline & $\begin{array}{c}\text { Pessoal } \\
\text { Econômico } \\
\text { Social }\end{array}$ & $\begin{array}{l}\text { Positivo } \\
\text { Positivo } \\
\text { Positivo }\end{array}$ & $\begin{array}{c}\text { Pessoal } \\
\text { Moral } \\
\text { Econômico }\end{array}$ & $\begin{array}{c}\text { Positivo } \\
\text { Negativo } \\
\text { Positivo }\end{array}$ \\
\hline $\begin{array}{c}\text { Descrições feitas } \\
\text { pelos bancários }\end{array}$ & \multicolumn{2}{|c|}{ Descrição do Trabalho } & \multicolumn{2}{|c|}{ Descrição do Consumo e do Consumidor } \\
\hline
\end{tabular}

Figura 23 - $\quad$ Análise dos dados do Entrevistado: 20

Fonte: Dados de pesquisa 


\begin{tabular}{|c|c|c|}
\cline { 2 - 3 } \multicolumn{1}{c|}{} & \multicolumn{2}{c|}{ Tipificações } \\
\cline { 2 - 3 } \multicolumn{1}{c|}{ Eu } & Trabalhador & Consumidor \\
\hline & Eu - trabalhador & Eu - consumidor \\
\hline & Muito dedicado & Não sou impulsivo \\
Pessoa engajada & Analiso bastante \\
\hline Sou firme nas decisões & \\
\hline Outro & Sou transparente, honesta e cordial & Consumidor \\
& Estou trabalhando, tenho direito de consumir & Tem todo tipo de cliente \\
& Colega de trabalho & O maior artigo que uma empresa pode ter \\
\hline
\end{tabular}

\begin{tabular}{|c|c|c|}
\hline & $\begin{array}{c}\text { Ser muito dedicado } \\
\text { Ser engajado } \\
\text { Ser firme nas decisões } \\
\text { Ser transparente } \\
\text { Ser honesta e cordial } \\
\text { Ter o direito de consumir } \\
\text { Assumir responsabilidades } \\
\text { Estar com o colega a todo momento }\end{array}$ & $\begin{array}{c}\text { Não ser impulsivo } \\
\text { Analisar bastante } \\
\text { Ser de todo tipo } \\
\text { Ser o maior artigo de uma empresa }\end{array}$ \\
\hline $\begin{array}{c}\text { Referências } \\
\text { Identitárias } \\
\text { Predominantes } \\
\end{array}$ & $\begin{array}{c}\text { O que é ser } \\
\text { Bancário }\end{array}$ & O que é ser Consumidor \\
\hline
\end{tabular}

\begin{tabular}{|c|c|}
\hline Ser bancário X & Prefere ser bancário \\
Ser consumidor & Prefere ser da organização \\
\hline Ser bancário X & \\
Ser organização & \\
\hline
\end{tabular}

\begin{tabular}{|l|l|}
\hline Referências sociais & Organização \\
\hline
\end{tabular}

Variável Estudada $\quad$ Identidade Social

\begin{tabular}{|c|c|c|c|c|}
\cline { 2 - 5 } \multicolumn{1}{c|}{} & Valor & Sentido & Valor & Sentido \\
\cline { 2 - 4 } \multicolumn{1}{c|}{} & $\begin{array}{c}\text { Pessoal } \\
\text { Moral }\end{array}$ & $\begin{array}{c}\text { Positivo } \\
\text { Positivo }\end{array}$ & $\begin{array}{c}\text { Possoal } \\
\text { Social }\end{array}$ & Positivo \\
\hline $\begin{array}{c}\text { Descrições feitas } \\
\text { pelos bancários }\end{array}$ & \multicolumn{2}{|c|}{ Descrição do Trabalho } & Descrição do Consumo e do Consumidor \\
\hline
\end{tabular}

Figura 24 - $\quad$ Análise dos dados do Entrevistado: 21

Fonte: Dados de pesquisa 


\begin{tabular}{|c|c|c|}
\hline & \multicolumn{2}{|c|}{ Tipificações } \\
\hline & Trabalhador & Consumidor \\
\hline $\mathrm{Eu}$ & Eu - trabalhador & Eu - consumidor \\
\hline & $\begin{array}{c}\text { Menos status } \\
\text { Lida com gente } \\
\text { Comprometida com o trabalho } \\
\text { Visto a camisa da empresa } \\
\text { Gosto de trabalhar } \\
\text { Define quem eu sou } \\
\end{array}$ & $\begin{array}{c}\text { Gosto de comprar } \\
\text { Evito gastos com coisas supérfluas } \\
\text { Consumidor moderado } \\
\text { Quer satisfação }\end{array}$ \\
\hline Outro & Colega de trabalho & Consumidor \\
\hline & $\begin{array}{c}\text { Minha segunda família } \\
\text { Personalidades diferentes } \\
\text { Relativamente até que é unida } \\
\text { Classe sufocada } \\
\text { A pressão em cima dos funcionários em atingir } \\
\text { metas }\end{array}$ & É o maior patrimônio do banco \\
\hline
\end{tabular}

\begin{tabular}{|c|c|c|}
\hline & $\begin{array}{c}\text { Ter menos status } \\
\text { Lidar com gente } \\
\text { Ser comprometido com o trabalho } \\
\text { Vestir a camisa da empresa } \\
\text { Gostar de trabalhar } \\
\text { Ser alguém } \\
\text { Ser da família } \\
\text { Ter personalidades diferentes } \\
\text { Ser relativamente unidos } \\
\text { Ser sufocado } \\
\text { Ser pressionado para atingir metas }\end{array}$ & $\begin{array}{c}\text { Gostar de comprar } \\
\text { Evitar gastos com coisas supérfluas } \\
\text { Ser consumir moderadamente } \\
\text { Ser maior patrimônio }\end{array}$ \\
\hline $\begin{array}{l}\text { Referências } \\
\text { Identitárias } \\
\text { Predominantes } \\
\end{array}$ & $\begin{array}{c}\text { O que é ser } \\
\text { Bancário }\end{array}$ & O que é ser Consumidor \\
\hline
\end{tabular}

\begin{tabular}{|c|c|}
\hline Ser bancário X & Prefere ser consumidor \\
Ser consumidor & Prefere ser da organização \\
\hline Ser bancário X & \\
Ser organização & \\
\hline
\end{tabular}

Variável Estudada $\quad$ Identidade Social

\begin{tabular}{|c|c|c|c|c|}
\cline { 2 - 5 } \multicolumn{1}{c|}{} & Valor & Sentido & Valor & Sentido \\
\cline { 2 - 5 } & Pessoal & Contraditório & Pessoal & Positivo \\
Moral & Pogativo \\
Econômico & Positivo & Eositivo & Econômico & Descrição do Consumo e do Consumidor \\
\hline $\begin{array}{c}\text { Descrições feitas } \\
\text { pelos bancários }\end{array}$ & \multicolumn{2}{|c|}{ Descrição do Trabalho } & Pono \\
\hline
\end{tabular}

Figura 25 - $\quad$ Análise dos dados do Entrevistado: 22

Fonte: Dados de pesquisa 


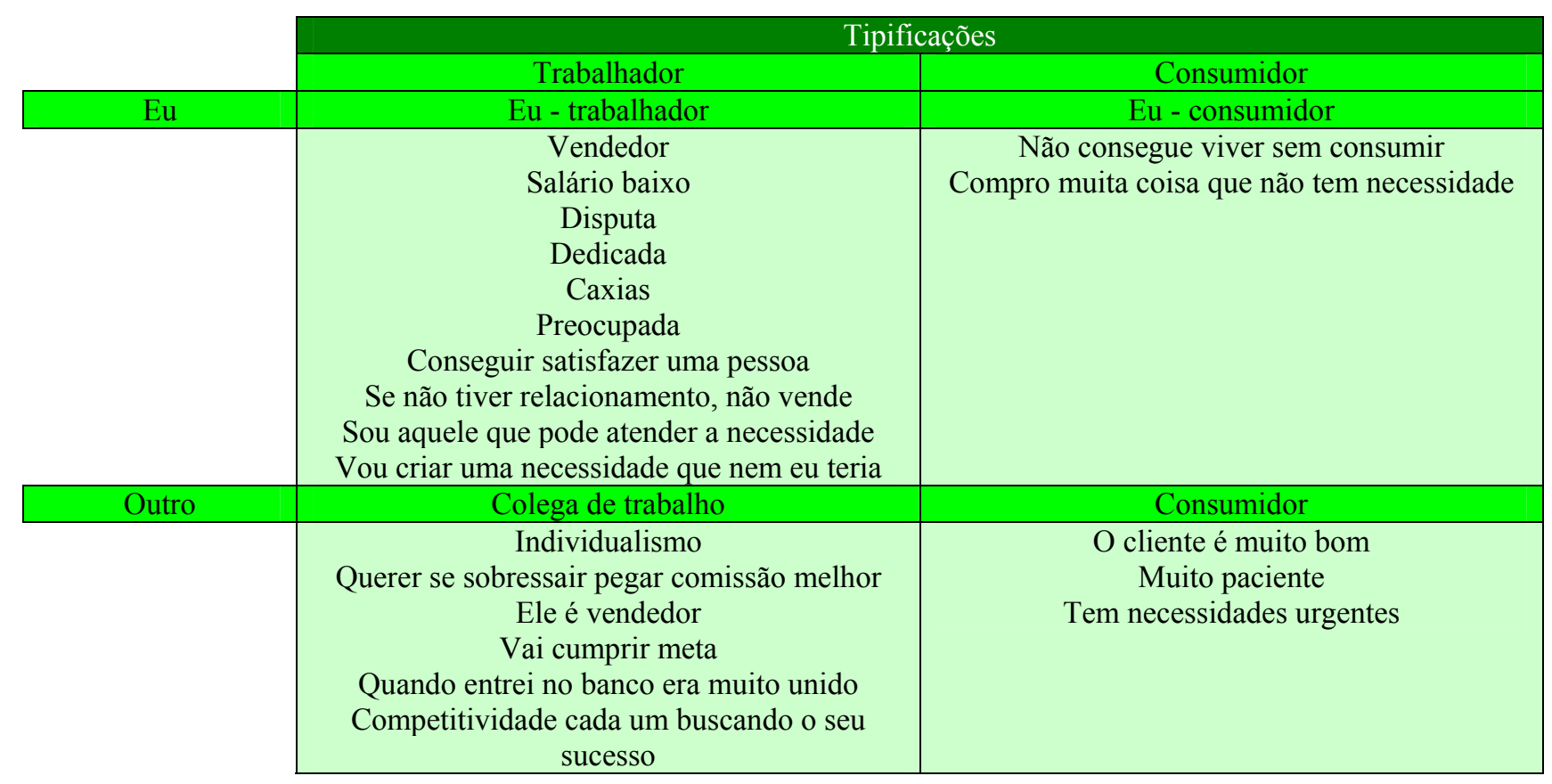

\begin{tabular}{|c|c|c|}
\hline & $\begin{array}{c}\text { Vendedor } \\
\text { Ter salário baixo } \\
\text { Disputar } \\
\text { Ser dedicado } \\
\text { Ser Caxias } \\
\text { Preocupar-se } \\
\text { Conseguir satisfazer uma pessoa } \\
\text { Ter relacionamento } \\
\text { Poder atender a necessidade } \\
\text { Criar uma necessidade }\end{array}$ & $\begin{array}{c}\text { Não conseguir viver sem consumir } \\
\text { Comprar o que não tem necessidade } \\
\text { Ser muito bom } \\
\text { Ser muito paciente } \\
\text { Ter necessidades urgentes }\end{array}$ \\
\hline $\begin{array}{c}\text { Referências } \\
\text { Identitárias } \\
\text { Predominantes }\end{array}$ & $\begin{array}{c}\text { O que é ser } \\
\text { Bancário }\end{array}$ & O que é ser Consumidor \\
\hline
\end{tabular}

\begin{tabular}{|c|c|}
\hline $\begin{array}{l}\text { Ser bancário X } \\
\text { Ser consumidor }\end{array}$ & Prefere ser bancário \\
\hline $\begin{array}{c}\text { Ser bancário X } \\
\text { Ser organização }\end{array}$ & Prefere ser da organização \\
\hline
\end{tabular}

\begin{tabular}{|c|c|}
\hline Referências sociais & Organização \\
\hline Variável Estudada & Identidade Social \\
\hline
\end{tabular}

\begin{tabular}{|c|c|c|c|c|}
\hline & Valor & Sentido & Valor & Sentido \\
\hline & Pessoal & Positivo & $\begin{array}{c}\text { Pessoal } \\
\text { Moral } \\
\text { Econômico }\end{array}$ & $\begin{array}{c}\text { Positivo } \\
\text { Negativo } \\
\text { Positivo }\end{array}$ \\
\hline $\begin{array}{l}\text { Descrições feitas } \\
\text { pelos bancários }\end{array}$ & \multicolumn{2}{|c|}{ Descrição do Trabalho } & \multicolumn{2}{|c|}{ Descrição do Consumo e do Consumidor } \\
\hline
\end{tabular}

Figura 26 - Análise dos dados do Entrevistado: 23

Fonte: Dados de pesquisa 


\begin{tabular}{|c|c|c|}
\hline & \multicolumn{2}{|c|}{ Tipificações } \\
\hline & Trabalhador & Consumidor \\
\hline$\overline{\mathrm{Eu}}$ & Eu - trabalhador & Eu - consumidor \\
\hline & $\begin{array}{c}\text { Facilidades tecnológicas } \\
\text { Menos direitos } \\
\text { Contato com clientes } \\
\text { Se todo bancário fizesse o que eu faço } \\
\text { Visto a camisa } \\
\text { Não faço pela metade } \\
\text { Me dou nota nove } \\
\text { Trabalho é mecânico }\end{array}$ & $\begin{array}{l}\text { Sou altamente consumista } \\
\text { Sou compulsiva } \\
\text { Não planejo as minhas coisas }\end{array}$ \\
\hline Outro & Colega de trabalho & Consumidor \\
\hline & $\begin{array}{c}\text { Relaciono bem } \\
\text { Não tem tempo de relacionar } \\
\text { Muito distante } \\
\text { Difícil entrosamento } \\
\text { A distância dos grandes centros, categoria } \\
\text { muito desunida } \\
\text { A gente envolvia mais com os sindicatos }\end{array}$ & $\begin{array}{c}\text { Sem eles a gente não vive } \\
\text { Bonzinho } \\
\text { Pedras na mão } \\
\text { A gente depende deles para viver } \\
\text { Ele é a nossa vida }\end{array}$ \\
\hline
\end{tabular}

\begin{tabular}{|c|c|c|}
\hline & $\begin{array}{c}\text { Lidar com facilidades tecnológicas } \\
\text { Ter menos direitos } \\
\text { Fazer contato com clientes } \\
\text { Vestir a camisa } \\
\text { Não fazer pela metade } \\
\text { Trabalhar mecanicamente }\end{array}$ & $\begin{array}{c}\text { Ser consumista } \\
\text { Ser compulsiva } \\
\text { Não planejar as suas coisas } \\
\text { Ser bonzinho } \\
\text { Ter pedras na mão } \\
\text { Ser fonte de dependência de alguém } \\
\text { Ser a vida de alguém }\end{array}$ \\
\hline $\begin{array}{l}\text { Referências } \\
\text { Identitárias } \\
\text { Predominantes }\end{array}$ & $\begin{array}{l}\text { O que é ser } \\
\text { Bancário }\end{array}$ & O que é ser Consumidor \\
\hline
\end{tabular}

\begin{tabular}{|c|c|} 
Ser bancário X & Prefere ser bancário \\
Ser consumidor & Prefere ser da organização \\
\hline Ser bancário X & \\
Ser organização & \\
\hline
\end{tabular}

Referências sociais $\quad$ Referência a características pessoais

Variável Estudada $\quad$ Identidade Social

\begin{tabular}{|c|c|c|c|c|}
\cline { 2 - 4 } \multicolumn{1}{c|}{} & Valor & Sentido & Valor & Sentido \\
\cline { 2 - 5 } & Pessoal & Positivo & Pessoal \\
& Econômico & Positivo & Moral & Negativo \\
Econômico & Positivo \\
Social & Positivo \\
\hline $\begin{array}{c}\text { Descrições feitas } \\
\text { pelos bancários }\end{array}$ & \multicolumn{2}{|c|}{ Descrição do Trabalho } & Descrição do Consumo e do Consumidor \\
\hline
\end{tabular}

Figura 27 - $\quad$ Análise dos dados do Entrevistado: 24

Fonte: Dados de pesquisa 


\begin{tabular}{|c|c|c|}
\cline { 2 - 3 } \multicolumn{1}{c|}{} & \multicolumn{2}{c|}{ Tipificações } \\
\cline { 2 - 3 } \multicolumn{1}{c|}{} & Trabalhador & Consumidor \\
\hline Eu & Eu - trabalhador & Eu - consumidor \\
\hline & Presta serviço à comunidade & Consumo é necessário para sobreviver \\
Orienta pessoas & Tira meu estresse \\
& Qualificado & Consome sem necessidade \\
& Eu preciso do cliente & Fácil de se levar se for respeitado \\
& Se preocupa em preparar & Não se prepara para fazer o melhor \\
\hline Outro & Colega de trabalho & Consumidor \\
\hline & Muito desunida, pois cada um trabalha num & Alguém que precisa de alguma coisa do banco \\
& setor & \\
\cline { 2 - 3 } & Cada banco foca um público alvo. & \\
\hline
\end{tabular}

\begin{tabular}{|c|c|c|}
\hline & $\begin{array}{c}\text { Prestar serviço à comunidade } \\
\text { Orientar pessoas } \\
\text { Ser qualificado } \\
\text { Precisar do cliente } \\
\text { Preocupar-se em preparar } \\
\end{array}$ & $\begin{array}{c}\text { Ser necessário para sobreviver } \\
\text { Tirar seu estresse } \\
\text { Consumir sem necessidade } \\
\text { Ser fácil de ser levado } \\
\text { Não se preparar para fazer o melhor }\end{array}$ \\
\hline $\begin{array}{c}\text { Referências } \\
\text { Identitárias } \\
\text { Predominantes }\end{array}$ & $\begin{array}{l}\text { O que é ser } \\
\text { Bancário }\end{array}$ & O que é ser Consumidor \\
\hline
\end{tabular}

\begin{tabular}{|c|c|}
\hline Ser bancário X & Prefere ser consumidor \\
Ser consumidor & Prefere ser da organização \\
\hline Ser bancário X & \\
Ser organização & \\
\hline
\end{tabular}

\begin{tabular}{|c|c|}
\hline Referências sociais & Bancário \\
\hline Variável Estudada & Identidade Social \\
\hline
\end{tabular}

\begin{tabular}{|c|c|c|c|c|}
\cline { 2 - 5 } \multicolumn{1}{c|}{} & Valor & Sentido & Valor & Sentido \\
\cline { 2 - 5 } & $\begin{array}{c}\text { Pessoal } \\
\text { Econômico }\end{array}$ & $\begin{array}{c}\text { Contraditório } \\
\text { Positivo }\end{array}$ & $\begin{array}{c}\text { Pessoal } \\
\text { Econômico } \\
\text { Moral }\end{array}$ & $\begin{array}{c}\text { Positivo } \\
\text { Negativo }\end{array}$ \\
\hline $\begin{array}{c}\text { Descrições feitas } \\
\text { pelos bancários }\end{array}$ & \multicolumn{2}{|c|}{ Descrição do Trabalho } & Descrição do Consumo e do Consumidor \\
\hline
\end{tabular}

Figura 28 - $\quad$ Análise dos dados do Entrevistado: 25

Fonte: Dados de pesquisa 


\begin{tabular}{|c|c|c|}
\hline & \multicolumn{2}{|c|}{ Tipificações } \\
\hline & Trabalhador & Consumidor \\
\hline \multirow[t]{2}{*}{$\mathrm{Eu}$} & Eu - trabalhador & Eu - consumidor \\
\hline & $\begin{array}{c}\text { Concorrência } \\
\text { Menos Status } \\
\text { Ir atrás do cliente } \\
\text { Deixar o cliente satisfeito } \\
\text { Sou exigente comigo mesmo } \\
\text { Busco produtos que atendam a necessidade do } \\
\text { consumidor } \\
\text { É menos exigente }\end{array}$ & $\begin{array}{l}\text { Sou exigente } \\
\text { Gosto de ser bem atendido } \\
\text { Exige como faz no trabalho } \\
\text { É mais exigente }\end{array}$ \\
\hline \multirow[t]{2}{*}{ Outro } & Colega de trabalho & Consumidor \\
\hline & $\begin{array}{c}\text { Muito parceiro } \\
\text { Companheiro } \\
\text { Estão bem fortes hoje } \\
\text { Vem crescendo o número de bancários }\end{array}$ & $\begin{array}{l}\text { Ele está mais informado } \\
\text { Ele tem uma exigência muito grande } \\
\text { O cliente tem muita força }\end{array}$ \\
\hline
\end{tabular}

\begin{tabular}{|c|c|c|}
\hline & $\begin{array}{c}\text { Ser concorrente } \\
\text { Ter menor status } \\
\text { Ir atrás do cliente } \\
\text { Deixar o cliente satisfeito } \\
\text { Ser exigente consigo mesmo } \\
\text { Buscar produtos para atender a necessidade do } \\
\text { cliente } \\
\text { Ser menos exigente }\end{array}$ & $\begin{array}{c}\text { Ser exigente } \\
\text { Ser bem atendido } \\
\text { Exigir como faz no trabalho } \\
\text { Ser mais informado } \\
\text { Ter muita força }\end{array}$ \\
\hline $\begin{array}{c}\text { Referências } \\
\text { Identitárias } \\
\text { Predominantes }\end{array}$ & $\begin{array}{l}\text { O que é ser } \\
\text { Bancário }\end{array}$ & O que é ser Consumidor \\
\hline
\end{tabular}

Ser bancário X

Ser consumidor

Ser bancário X

Ser organização

Prefere ser da organização

Referências sociais $\quad$ Organização

Variável Estudada $\quad$ Identidade Social

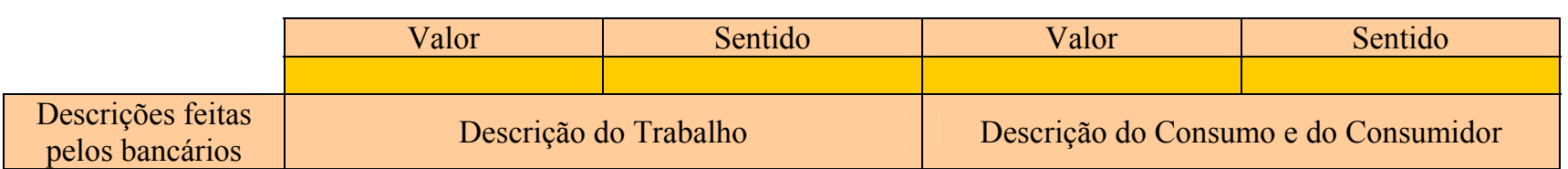

Figura 29 - $\quad$ Análise dos dados do Entrevistado: 26

Fonte: Dados de pesquisa 


\begin{tabular}{|c|c|c|}
\hline & \multicolumn{2}{|c|}{ Tipificações } \\
\hline & Trabalhador & Consumidor \\
\hline \multirow[t]{2}{*}{$\mathrm{Eu}$} & Eu - trabalhador & Eu - consumidor \\
\hline & $\begin{array}{l}\text { Atende demandas do cliente } \\
\text { Atender as expectativas do cliente } \\
\text { Gosto do que faço } \\
\text { Gosto de ser bancário } \\
\text { Posso ajudar as pessoas }\end{array}$ & $\begin{array}{l}\text { Consumidor compulsivo } \\
\text { Gosta de consumir } \\
\text { Não tem medo de errar }\end{array}$ \\
\hline \multirow[t]{2}{*}{ Outro } & Colega de trabalho & Consumidor \\
\hline & $\begin{array}{c}\text { Guerreiros } \\
\text { Tem aqueles que amam ser bancários } \\
\text { Outros acham que é um bico } \\
\text { A comunidade vê como uma profissão boa } \\
\text { Trabalho bancário é estressante } \\
\text { Trabalho repetitivo } \\
\text { Bem vista pela comunidade }\end{array}$ & $\begin{array}{l}\text { É alguém que tem uma perspectiva de } \\
\text { consumo } \\
\text { Uma demanda por um produto ou serviço }\end{array}$ \\
\hline
\end{tabular}

\begin{tabular}{|c|c|c|}
\hline & $\begin{array}{c}\text { Atender as demandas do cliente } \\
\text { Gostar do que faz } \\
\text { Ajudar as pessoas } \\
\text { Ser guerreiro } \\
\text { Amar ser bancário ou achar que é bico } \\
\text { Ser estressado } \\
\text { Ser repetitivo } \\
\text { Ser bem visto pela comunidade }\end{array}$ & $\begin{array}{c}\text { Ser compulsivo } \\
\text { Gostar de consumir } \\
\text { Não ter medo de errar } \\
\text { Ter uma perspectiva de consumo } \\
\text { Ter uma demanda }\end{array}$ \\
\hline $\begin{array}{l}\text { Referências } \\
\text { Identitárias } \\
\text { Predominantes }\end{array}$ & $\begin{array}{c}\text { O que é ser } \\
\text { Bancário }\end{array}$ & O que é ser Consumidor \\
\hline
\end{tabular}

\begin{tabular}{|c|c|}
\hline $\begin{array}{l}\text { Ser bancário X } \\
\text { Ser consumidor }\end{array}$ & Prefere ser consumidor \\
\hline $\begin{array}{c}\text { Ser bancário X } \\
\text { Ser organização }\end{array}$ & Prefere ser da organização \\
\hline
\end{tabular}

\begin{tabular}{|c|c|}
\hline Referências sociais & Organização \\
\hline Variável Estudada & Identidade Social \\
\hline
\end{tabular}

\begin{tabular}{|c|c|c|c|c|}
\cline { 2 - 4 } \multicolumn{1}{c|}{} & Valor & Sentido & Valor & Sentido \\
\cline { 2 - 4 } \multicolumn{1}{c|}{} & Pessoal & Positivo & $\begin{array}{c}\text { Pessoal } \\
\text { Econômica }\end{array}$ & Positivo \\
\hline $\begin{array}{c}\text { Descrições feitas } \\
\text { pelos bancários }\end{array}$ & \multicolumn{2}{|c|}{ Descrição do Trabalho } & Descrição do Consumo e do Consumidor \\
\hline
\end{tabular}

Figura 30 - $\quad$ Análise dos dados do Entrevistado: 27

Fonte: Dados de pesquisa 


\begin{tabular}{|c|c|c|}
\hline & \multicolumn{2}{|c|}{ Tipificações } \\
\hline & Trabalhador & Consumidor \\
\hline $\mathrm{Eu}$ & Eu - trabalhador & Eu - consumidor \\
\hline & $\begin{array}{c}\text { Piores condições financeiras } \\
\text { Atendimento ao cliente } \\
\text { Nunca tive problema com cliente } \\
\text { Se coloca no lugar do cliente } \\
\text { É mais exigente trabalhando do que como } \\
\text { consumidor }\end{array}$ & $\begin{array}{l}\text { Quer produto que satisfaça } \\
\text { Não sou exigente }\end{array}$ \\
\hline Outro & Colega de trabalho & Consumidor \\
\hline & $\begin{array}{c}\text { Existem uns probleminhas } \\
\text { Convive bem } \\
\text { É bem visto na hora que vai fazer compras }\end{array}$ & $\begin{array}{c}\text { Meu ganha pão } \\
\text { Sem cliente não há banco } \\
\text { Cliente é fundamental } \\
\end{array}$ \\
\hline
\end{tabular}

\begin{tabular}{|c|c|c|}
\hline & $\begin{array}{c}\text { Estar em piores condições financeiras } \\
\text { Atender ao cliente } \\
\text { Não ter problema com cliente } \\
\text { Se colocar no lugar do cliente } \\
\text { Ser mais exigente trabalhando do que } \\
\text { consumindo } \\
\text { Conviver bem com colegas } \\
\text { Ser bem visto na hora que comprar }\end{array}$ & $\begin{array}{l}\text { Querer produto que satisfaça } \\
\text { Ser o ganha pão de alguém } \\
\text { Ser fundamental }\end{array}$ \\
\hline $\begin{array}{c}\text { Referências } \\
\text { Identitárias } \\
\text { Predominantes }\end{array}$ & $\begin{array}{l}\text { O que é ser } \\
\text { Bancário }\end{array}$ & O que é ser Consumidor \\
\hline
\end{tabular}

\begin{tabular}{|c|c|}
\hline Ser bancário X & Prefere ser bancário \\
Ser consumidor & Prefere ser da organização \\
\hline Ser bancário X & \\
Ser organização & \\
\hline
\end{tabular}

Referências sociais $\quad$ Atividades que realiza extra-trabalho

Variável Estudada $\quad$ Identidade Social

\begin{tabular}{|c|c|c|c|c|}
\hline & Valor & Sentido & Valor & Sentido \\
\hline & $\begin{array}{c}\text { Pessoal } \\
\text { Econômico } \\
\text { Social } \\
\text { Moral }\end{array}$ & $\begin{array}{l}\text { Positivo } \\
\text { Positivo } \\
\text { Positivo } \\
\text { Positivo }\end{array}$ & Pessoal & Positivo \\
\hline $\begin{array}{c}\text { Descrições feitas } \\
\text { pelos bancários }\end{array}$ & \multicolumn{2}{|c|}{ Descrição do Trabalho } & \multicolumn{2}{|c|}{ Descrição do Consumo e do Consumidor } \\
\hline
\end{tabular}

Figura 31 - $\quad$ Análise dos dados do Entrevistado: 28

Fonte: Dados de pesquisa 


\begin{tabular}{|c|c|c|}
\hline & \multicolumn{2}{|c|}{ Tipificações } \\
\hline & Trabalhador & Consumidor \\
\hline $\mathrm{Eu}$ & Eu - trabalhador & Eu - consumidor \\
\hline & $\begin{array}{l}\text { Muita pressão } \\
\text { Abrir mão da vida pessoal } \\
\text { Relacionamento } \\
\text { Correria }\end{array}$ & $\begin{array}{c}\text { Sou consumista } \\
\text { Sou exigente } \\
\text { Gosta de gastar dinheiro }\end{array}$ \\
\hline Outro & Colega de trabalho & Consumidor \\
\hline & $\begin{array}{c}\text { São todos louquinhos } \\
\text { Não sabe descrever. } \\
\text { Pessoas que gostam do que fazem ou que } \\
\text { precisam muito do dinheiro que ganham }\end{array}$ & $\begin{array}{l}\text { Uma pessoa muito exigente } \\
\text { Nem sempre tem paciência }\end{array}$ \\
\hline
\end{tabular}

\begin{tabular}{|c|c|c|}
\hline & $\begin{array}{c}\text { Ser pressionado } \\
\text { Abrir mão da vida pessoal } \\
\text { Relacionar-se } \\
\text { Correr } \\
\text { Ser louquinho } \\
\text { Não saber se descrever } \\
\text { Gostar do que faz ou precisar muito do } \\
\text { dinheiro }\end{array}$ & $\begin{array}{c}\text { Ser consumista } \\
\text { Ser exigente } \\
\text { Gostar de gastar dinheiro } \\
\text { Ser muito exigente } \\
\text { Não ter paciência sempre }\end{array}$ \\
\hline $\begin{array}{c}\text { Referências } \\
\text { Identitárias } \\
\text { Predominantes }\end{array}$ & $\begin{array}{c}\text { O que é ser } \\
\text { Bancário }\end{array}$ & O que é ser Consumidor \\
\hline
\end{tabular}

\begin{tabular}{|c|c|}
\hline Ser bancário X & Prefere ser bancário \\
Ser consumidor & Prefere ser da organização \\
\hline Ser bancário X & \\
Ser organização & \\
\hline
\end{tabular}

\begin{tabular}{|c|c|}
\hline Referências sociais & Organização \\
\hline Variável Estudada & Identidade Social \\
\hline
\end{tabular}

\begin{tabular}{|c|c|c|c|c|}
\cline { 2 - 5 } \multicolumn{1}{c|}{} & Valor & Sentido & Valor & Sentido \\
\cline { 2 - 5 } \multicolumn{1}{c|}{} & $\begin{array}{c}\text { Econômico } \\
\text { Pessoal }\end{array}$ & $\begin{array}{c}\text { Positivo } \\
\text { Contraditório }\end{array}$ & $\begin{array}{c}\text { Pessoal } \\
\text { Econômico }\end{array}$ & $\begin{array}{c}\text { Positivo } \\
\text { Positivo }\end{array}$ \\
\hline $\begin{array}{c}\text { Descrições feitas } \\
\text { pelos bancários }\end{array}$ & \multicolumn{2}{|c|}{ Descrição do Trabalho } & Descrição do Consumo e do Consumidor \\
\hline
\end{tabular}

Figura 32 - $\quad$ Análise dos dados do Entrevistado: 29

Fonte: Dados de pesquisa 


\begin{tabular}{|c|c|c|}
\hline & \multicolumn{2}{|c|}{ Tipificações } \\
\hline & Trabalhador & Consumidor \\
\hline $\mathrm{Eu}$ & Eu - trabalhador & Eu - consumidor \\
\hline $\begin{array}{c}\text { Prefere ser } \\
\text { Bancário }\end{array}$ & $\begin{array}{c}\text { Mais acelerado } \\
\text { Facilitar a vida da comunidade } \\
\text { Prestar serviços } \\
\text { Atender as pessoas } \\
\text { Sou feliz } \\
\text { Tenho prazer no que faço } \\
\text { Cumpro minhas metas } \\
\text { Enquadro o cliente como alguém da minha } \\
\text { família } \\
\text { Se identifica com os clientes }\end{array}$ & $\begin{array}{c}\text { Eu me estresso no supermercado } \\
\text { Sou muito cauteloso } \\
\text { Não sou afoito }\end{array}$ \\
\hline Outro & Colega de trabalho & Consumidor \\
\hline & $\begin{array}{c}\text { Pessoas que não têm prazer no atendimento } \\
\text { Fez concurso e passou } \\
\text { Já foi mais unida } \\
\text { Cada um ta na sua } \\
\text { Individual } \\
\end{array}$ & $\begin{array}{l}\text { Pessoa carente } \\
\text { Que tem um problema } \\
\text { Uma dificuldade } \\
\text { Uma necessidade }\end{array}$ \\
\hline
\end{tabular}

\begin{tabular}{|c|c|c|}
\hline & $\begin{array}{c}\text { Ser mais acelerado } \\
\text { Facilitar a vida da comunidade } \\
\text { Prestar serviços } \\
\text { Atender as pessoas } \\
\text { Ser feliz } \\
\text { Ter prazer no que faz } \\
\text { Cumprir metas } \\
\text { Enquadrar o cliente como alguém da minha } \\
\text { família } \\
\text { Identificar-se com os clientes }\end{array}$ & $\begin{array}{c}\text { Estressar-se no supermercado } \\
\text { Ser muito cauteloso } \\
\text { Não ser afoito } \\
\text { Ser carente } \\
\text { Ter um problema } \\
\text { Ter uma dificuldade } \\
\text { Ter uma necessidade }\end{array}$ \\
\hline $\begin{array}{c}\text { Referências } \\
\text { Identitárias } \\
\text { Predominantes }\end{array}$ & $\begin{array}{l}\text { O que é ser } \\
\text { Bancário }\end{array}$ & O que é ser Consumidor \\
\hline
\end{tabular}

\begin{tabular}{|c|c|}
\hline Ser bancário X & Prefere ser bancário \\
Ser consumidor & Prefere ser da organização \\
\hline Ser bancário X & \\
Ser organização & \\
\hline
\end{tabular}

\begin{tabular}{|c|c|}
\hline Referências sociais & Organização \\
\hline Variável Estudada & Identidade Social \\
\hline
\end{tabular}

\begin{tabular}{|c|c|c|c|c|}
\cline { 2 - 5 } \multicolumn{1}{c|}{} & Valor & Sentido & Valor & Sentido \\
\cline { 2 - 5 } & Pessoal & Contraditório & Pessoal & Negativo \\
& Moral & Positivo & Moral & Positivo \\
\hline $\begin{array}{c}\text { Descrições feitas } \\
\text { Eelos bancários }\end{array}$ & \multicolumn{2}{c|}{ Positivo } & Econômico & Descrição do Consumo e do Consumidor \\
\hline
\end{tabular}

Figura 33 - $\quad$ Análise dos dados do Entrevistado: 30

Fonte: Dados de pesquisa 


\begin{tabular}{|c|c|c|}
\hline & \multicolumn{2}{|c|}{ Tipificações } \\
\hline & Trabalhador & Consumidor \\
\hline $\mathrm{Eu}$ & Eu - trabalhador & Eu - consumidor \\
\hline & $\begin{array}{l}\text { Trato com as pessoas } \\
\text { Conhecer os produtos } \\
\text { Acredita no trabalho que faz } \\
\text { Importância do bancário } \\
\text { Não consegue alcançar o cliente }\end{array}$ & $\begin{array}{l}\text { Faço reflexão } \\
\text { Sou racional }\end{array}$ \\
\hline Outro & Colega de trabalho & Consumidor \\
\hline & $\begin{array}{l}\text { Tem muito a desenvolver ainda } \\
\text { Parecia que tinha uma coesão maior } \\
\text { O mercado não era tão competitivo }\end{array}$ & $\begin{array}{c}\text { Preocupado como vai ser atendido } \\
\text { Exige qualidade }\end{array}$ \\
\hline
\end{tabular}

\begin{tabular}{|c|c|c|}
\hline & $\begin{array}{c}\text { Tratar com as pessoas } \\
\text { Conhecer os produtos } \\
\text { Acreditar no trabalho que faz } \\
\text { Ser importante } \\
\text { Não conseguir alcançar o cliente } \\
\text { Ter muito a desenvolver } \\
\text { Ser menos coesos } \\
\text { Ser competitivo }\end{array}$ & $\begin{array}{c}\text { Refletir } \\
\text { Ser racional } \\
\text { Ser preocupado como vai ser atendido } \\
\text { Exigir qualidade }\end{array}$ \\
\hline $\begin{array}{c}\text { Referências } \\
\text { Identitárias } \\
\text { Predominantes }\end{array}$ & $\begin{array}{c}\text { O que é ser } \\
\text { Bancário }\end{array}$ & O que é ser Consumidor \\
\hline
\end{tabular}

\begin{tabular}{|c|c|}
\hline Ser bancário X & Prefere ser bancário \\
Ser consumidor & Prefere ser da organização \\
\hline Ser bancário X & \\
Ser organização & \\
\hline
\end{tabular}

\begin{tabular}{|c|c|}
\hline Referências sociais & Organização \\
\hline Variável Estudada & Identidade Social \\
\hline
\end{tabular}

\begin{tabular}{|c|c|c|c|c|}
\cline { 2 - 5 } \multicolumn{1}{c|}{} & Valor & Sentido & Valor & Sentido \\
\cline { 2 - 5 } & Moral & Positivo & Pessoal \\
Pessoal & Positivo & Moral & Negativo \\
Econômico & Positivo \\
Social & Negativo \\
\hline $\begin{array}{c}\text { Descrições feitas } \\
\text { pelos bancários }\end{array}$ & & Descrição do Consumo e do Consumidor \\
\hline
\end{tabular}

Figura 34 - $\quad$ Análise dos dados do Entrevistado: 31

Fonte: Dados de pesquisa 


\begin{tabular}{|c|c|c|}
\hline & \multicolumn{2}{|c|}{ Tipificações } \\
\hline & Trabalhador & Consumidor \\
\hline \multirow[t]{2}{*}{$\mathrm{Eu}$} & Eu - trabalhador & Eu - consumidor \\
\hline & $\begin{array}{c}\text { Liberdade } \\
\text { Menos autoritário } \\
\text { Consultor financeiro } \\
\text { Trata das finanças das pessoas } \\
\text { Gosto do que faço } \\
\text { Sou uma boa profissional } \\
\text { Tem que ser profissional } \\
\text { Amizade com cliente }\end{array}$ & $\begin{array}{c}\text { Procuro preço e qualidade } \\
\text { Não sou impulsiva } \\
\text { Eu era } \\
\text { Me diz o que tu compras e te direi quem tu és }\end{array}$ \\
\hline \multirow[t]{2}{*}{ Outro } & Colega de trabalho & Consumidor \\
\hline & $\begin{array}{c}\text { Parceiro } \\
\text { Colega } \\
\text { Amigos } \\
\text { São unidos } \\
\text { Estão se sentido acuados }\end{array}$ & $\begin{array}{l}\text { Pessoa que vem procurando ajuda } \\
\text { Quer consolo }\end{array}$ \\
\hline
\end{tabular}

\begin{tabular}{|c|c|c|}
\hline & $\begin{array}{c}\text { Ter liberdade } \\
\text { Ser menos autoritário } \\
\text { Ser consultor financeiro } \\
\text { Tratar das finanças das pessoas } \\
\text { Gostar do que faz } \\
\text { Ser bom profissional } \\
\text { Ter amizade com o cliente } \\
\text { Ser parceiro } \\
\text { Ser colega } \\
\text { Ser amigo } \\
\text { Ser unido } \\
\text { Sentir-se acuado }\end{array}$ & $\begin{array}{l}\text { Procurar preço e qualidade } \\
\text { Não ser impulsivo } \\
\text { Procurar ajuda } \\
\text { Querer consolo }\end{array}$ \\
\hline $\begin{array}{c}\text { Referências } \\
\text { Identitárias } \\
\text { Predominantes }\end{array}$ & $\begin{array}{c}\text { O que é ser } \\
\text { Bancário }\end{array}$ & O que é ser Consumidor \\
\hline
\end{tabular}

\begin{tabular}{|c|c|}
\hline Ser bancário X & Prefere ser bancário \\
Ser consumidor & Prefere ser da organização \\
\hline Ser bancário X & \\
Ser organização & \\
\hline
\end{tabular}

\begin{tabular}{|c|c|}
\hline Referências sociais & Família \\
\hline Variável Estudada & Identidade Social \\
\hline
\end{tabular}

\begin{tabular}{|c|c|c|c|c|}
\cline { 2 - 4 } \multicolumn{1}{c|}{} & Valor & Sentido & Valor & Pentido \\
\cline { 2 - 4 } \multicolumn{1}{c|}{} & $\begin{array}{c}\text { Pessoal } \\
\text { Econômico } \\
\text { Moral }\end{array}$ & $\begin{array}{r}\text { Positivo } \\
\text { Positivo } \\
\text { Positivo }\end{array}$ & Pessoal \\
\hline $\begin{array}{c}\text { Descrições feitas } \\
\text { pelos bancários }\end{array}$ & \multicolumn{2}{|c|}{ Descrição do Trabalho } & Descrição do Consumo e do Consumidor \\
\hline
\end{tabular}

Figura 35 - $\quad$ Análise dos dados do Entrevistado: 32

Fonte: Dados de pesquisa 


\begin{tabular}{|c|c|c|}
\hline & \multicolumn{2}{|c|}{ Tipificações } \\
\hline & Trabalhador & Consumidor \\
\hline \multirow[t]{2}{*}{$\mathrm{Eu}$} & Eu - trabalhador & Eu - consumidor \\
\hline & $\begin{array}{l}\text { Lida com dinheiro dos outros } \\
\text { Tento fazer o melhor } \\
\text { Honesto } \\
\text { Quer atender as necessidades }\end{array}$ & $\begin{array}{l}\text { Gosto de comprar mas não sou compulsiva } \\
\text { Me dá prazer } \\
\text { Quer ser tratada como trata seus clientes }\end{array}$ \\
\hline \multirow[t]{2}{*}{ Outro } & Colega de trabalho & Consumidor \\
\hline & $\begin{array}{c}\text { Competitivos } \\
\text { Não tem aquela amizade de antigamente. } \\
\text { Não tem aquele companheirismo } \\
\text { Já foi uma categoria bem mais unida } \\
\text { Dispersou muito }\end{array}$ & $\begin{array}{c}\text { Vem em primeiro lugar, antes de qualquer } \\
\text { coisa } \\
\text { Sem cliente o banco vai pro buraco }\end{array}$ \\
\hline
\end{tabular}

\begin{tabular}{|c|c|c|}
\hline & $\begin{array}{c}\text { Lidar com dinheiro dos outros } \\
\text { Fazer o melhor } \\
\text { Ser honesto } \\
\text { Querer atender as necessidades } \\
\text { Ser competitivo } \\
\text { Não ter a amizade de antigamente } \\
\text { Não ser companheiro } \\
\text { Não ser mais unidos }\end{array}$ & $\begin{array}{l}\text { Gostar de comprar } \\
\text { Não ser compulsivo } \\
\text { Sentir prazer } \\
\text { Ser tratado como trata } \\
\text { Vir em primeiro lugar }\end{array}$ \\
\hline $\begin{array}{c}\text { Referências } \\
\text { Identitárias } \\
\text { Predominantes }\end{array}$ & $\begin{array}{l}\text { O que é ser } \\
\text { Bancário }\end{array}$ & O que é ser Consumidor \\
\hline
\end{tabular}

\begin{tabular}{|c|c|}
\hline Ser bancário X & Prefere ser bancário \\
Ser consumidor & Prefere ser da organização \\
\hline Ser bancário X & \\
Ser organização & \\
\hline
\end{tabular}

\begin{tabular}{|c|c|}
\hline Referências sociais & Referência a características pessoais \\
\hline Variável Estudada & Identidade Social \\
\hline
\end{tabular}

\begin{tabular}{|c|c|c|c|c|}
\cline { 2 - 5 } \multicolumn{1}{c|}{} & Valor & Sentido & Valor & Sentido \\
\cline { 2 - 5 } \multicolumn{1}{c|}{} & $\begin{array}{c}\text { Pessoal } \\
\text { Econômico }\end{array}$ & $\begin{array}{c}\text { Positivo } \\
\text { Positivo }\end{array}$ & $\begin{array}{c}\text { Pessoal } \\
\text { Econômico }\end{array}$ & Positivo \\
\hline $\begin{array}{c}\text { Descrições feitas } \\
\text { pelos bancários }\end{array}$ & \multicolumn{2}{|c|}{ Descrição do Trabalho } & Descrição do Consumo e do Consumidor \\
\hline
\end{tabular}

\section{Figura 36 - $\quad$ Análise dos dados do Entrevistado: 33}

Fonte: Dados de pesquisa 


\begin{tabular}{|c|c|c|}
\hline & \multicolumn{2}{|c|}{ Tipificações } \\
\hline & Trabalhador & Consumidor \\
\hline \multirow[t]{2}{*}{$\mathrm{Eu}$} & Eu - trabalhador & Eu - consumidor \\
\hline & $\begin{array}{c}\text { Trabalho intenso } \\
\text { Responsabilidade } \\
\text { Intermediário } \\
\text { Não tenho um perfil estabelecido } \\
\text { Aprendi a lidar com pessoas }\end{array}$ & $\begin{array}{l}\text { Sou consumidor cauteloso } \\
\text { Gosto de fazer boas compras }\end{array}$ \\
\hline \multirow[t]{2}{*}{ Outro } & Colega de trabalho & Consumidor \\
\hline & $\begin{array}{l}\text { Muito bom. Um nível excelente } \\
\text { Nível elevado } \\
\text { Categoria forte, muito unida } \\
\text { Profissional de valor muito grande }\end{array}$ & $\begin{array}{c}\text { Variado } \\
\text { É aquele que precisa sair satisfeito }\end{array}$ \\
\hline
\end{tabular}

\begin{tabular}{|c|c|c|}
\hline & \multirow[b]{2}{*}{$\begin{array}{c}\text { Trabalhar intensamente } \\
\text { Ter responsabilidade } \\
\text { Ser intermediário } \\
\text { Não ter perfil estabelecido } \\
\text { Aprender a lidar com as pessoas } \\
\text { Ter nível excelente } \\
\text { Ter nível elevado } \\
\text { Ser forte } \\
\text { Ser unido } \\
\text { Ter valor muito grande }\end{array}$} & \multirow[b]{2}{*}{$\begin{array}{c}\text { Ser consumidor cauteloso } \\
\text { Gostar de fazer compras } \\
\text { Ser variado } \\
\text { Precisar sair satisfeito }\end{array}$} \\
\hline & & \\
\hline $\begin{array}{c}\text { Referências } \\
\text { Identitárias } \\
\text { Predominantes }\end{array}$ & $\begin{array}{c}\text { O que é ser } \\
\text { Bancário }\end{array}$ & O que é ser Consumidor \\
\hline
\end{tabular}

\begin{tabular}{|c|c|}
\hline Ser bancário X & Prefere ser bancário \\
Ser consumidor & Prefere ser da organização \\
\hline Ser bancário X & \\
Ser organização & \\
\hline
\end{tabular}

Organização
Identidade Social

\begin{tabular}{|c|c|c|c|c|}
\cline { 2 - 5 } \multicolumn{1}{c|}{} & Valor & Sentido & Valor & Sentido \\
\cline { 2 - 5 } & $\begin{array}{c}\text { Pessoal } \\
\text { Social } \\
\text { Econômico }\end{array}$ & $\begin{array}{c}\text { Positivo } \\
\text { Positivo } \\
\text { Positivo }\end{array}$ & Moral & Positivo \\
\hline $\begin{array}{c}\text { Descrições feitas } \\
\text { pelos bancários }\end{array}$ & \multicolumn{2}{|c|}{ Descrição do Trabalho } & Descrição do Consumo e do Consumidor \\
\hline
\end{tabular}

Figura 37 - $\quad$ Análise dos dados do Entrevistado: 34

Fonte: Dados de pesquisa 


\begin{tabular}{|c|c|c|}
\cline { 2 - 3 } \multicolumn{1}{c|}{} & \multicolumn{2}{c|}{ Tipificações } \\
\cline { 2 - 3 } \multicolumn{1}{c|}{} & Trabalhador & Consumidor \\
\hline $\mathrm{Eu}$ & Eu - trabalhador & Eu - consumidor \\
\hline & Relacionamento & Já foi compulsivo \\
& Vendedor & \\
\hline Outro controlado \\
& Tratar o cliente & \\
\hline & Fácil relacionamento & Consumidor \\
& Boa comunicação & Uma pessoa estranha \\
& Colega de trabalho & Alguém que precisa \\
\hline
\end{tabular}

\begin{tabular}{|c|c|c|}
\hline & $\begin{array}{c}\text { Relacionar-se } \\
\text { Vender } \\
\text { Tratar o cliente } \\
\text { Ser de fácil relacionamento } \\
\text { Ter boa comunicação } \\
\text { Ser parceiro do colega } \\
\text { Ser de confiança } \\
\text { Ser unido }\end{array}$ & $\begin{array}{c}\text { Ser compulsivo } \\
\text { Ser controlado } \\
\text { Ser estranho } \\
\text { Precisar }\end{array}$ \\
\hline $\begin{array}{c}\text { Referências } \\
\text { Identitárias } \\
\text { Predominantes }\end{array}$ & $\begin{array}{l}\text { O que é ser } \\
\text { Bancário }\end{array}$ & O que é ser Consumidor \\
\hline
\end{tabular}

\begin{tabular}{|c|c|}
\hline Ser bancário X & Prefere ser bancário \\
Ser consumidor & Prefere ser bancário \\
\hline Ser bancário X & \\
Ser organização & \\
\hline
\end{tabular}

\begin{tabular}{|c|c|}
\hline Referências sociais & Referência a características pessoais \\
\hline Variável Estudada & Identidade Social \\
\hline
\end{tabular}

\begin{tabular}{|c|c|c|c|c|}
\cline { 2 - 5 } \multicolumn{1}{c|}{} & Valor & Sentido & Valor & Sentido \\
\cline { 2 - 5 } & $\begin{array}{c}\text { Pessoal } \\
\text { Social } \\
\text { Econômico }\end{array}$ & $\begin{array}{c}\text { Positivo } \\
\text { Positivo } \\
\text { Positivo }\end{array}$ & Pessoal & Positivo \\
\hline $\begin{array}{c}\text { Descrições feitas } \\
\text { pelos bancários }\end{array}$ & \multicolumn{2}{c|}{ Descrição do Trabalho } & Descrição do Consumo e do Consumidor \\
\hline
\end{tabular}

\section{Figura 38 - $\quad$ Análise dos dados do Entrevistado: 35}

Fonte: Dados de pesquisa 


\begin{tabular}{|c|c|c|}
\cline { 2 - 3 } \multicolumn{1}{c|}{} & \multicolumn{2}{c|}{ Tipificações } \\
\cline { 2 - 3 } \multicolumn{1}{c|}{} & Trabalhador & Consumidor \\
\hline Eu & Eu - trabalhador & Eu - consumidor \\
Prefere ser & Mais qualificação & Gosto \\
& Metas & Tenho prazer em ser consumidor \\
Lancário & Gosto de ser bem atendida \\
\hline Outro & Colega de trabalho & Consumidor \\
\hline & Somos unidos & Cliente é uma pessoa difícil para mim \\
& São colegas & Muito complicado \\
& Uma família & Cliente tem sempre razão \\
& Muito estressante & \\
\hline
\end{tabular}

\begin{tabular}{|c|c|c|}
\hline & $\begin{array}{c}\text { Ser mais qualificado } \\
\text { Ter metas } \\
\text { Lidar com pessoas } \\
\text { Ser unido } \\
\text { Ser colega } \\
\text { Ser uma família } \\
\text { Estar estressado }\end{array}$ & $\begin{array}{c}\text { Gostar } \\
\text { Ter prazer } \\
\text { Ser difícil } \\
\text { Ser muito complicado } \\
\text { Ter sempre razão }\end{array}$ \\
\hline $\begin{array}{c}\text { Referências } \\
\text { Identitárias } \\
\text { Predominantes }\end{array}$ & $\begin{array}{l}\text { O que é ser } \\
\text { Bancário }\end{array}$ & O que é ser Consumidor \\
\hline
\end{tabular}

Ser bancário X

Ser consumidor

Ser bancário X

Ser organização

\section{Prefere ser bancário}

Prefere ser da organização

\begin{tabular}{l|l} 
Referências sociais & Organização
\end{tabular}

Variável Estudada $\quad$ Identidade Social

\begin{tabular}{|c|c|c|c|c|}
\cline { 2 - 5 } \multicolumn{1}{c|}{} & Valor & Sentido & Valor & Pentido \\
\cline { 2 - 5 } & $\begin{array}{c}\text { Pessoal } \\
\text { Moral } \\
\text { Econômico }\end{array}$ & $\begin{array}{c}\text { Contraditório } \\
\text { Positivo } \\
\text { Positivo }\end{array}$ & Positivo \\
\hline $\begin{array}{c}\text { Descrições feitas } \\
\text { pelos bancários }\end{array}$ & \multicolumn{2}{|c|}{ Descrição do Trabão do Consumo e do Consumidor } \\
\hline
\end{tabular}

Figura 39 - $\quad$ Análise dos dados do Entrevistado: 36

Fonte: Dados de pesquisa 


\begin{tabular}{|c|c|c|}
\hline & \multicolumn{2}{|c|}{ Tipificações } \\
\hline & Trabalhador & Consumidor \\
\hline \multirow[t]{7}{*}{$\mathrm{Eu}$} & Eu - trabalhador & Eu - consumidor \\
\hline & Mais cobrança & Sofisticado \\
\hline & Mais concorrência & Sou racional \\
\hline & Trabalha com dinheiro & Adquiro na medida em que preciso \\
\hline & Resolvendo uma necessidade & Preocupado \\
\hline & Dou conta do serviço & Quer bom atendimento \\
\hline & Trabalha para sustento material & \\
\hline \multirow[t]{6}{*}{ Outro } & Colega de trabalho & Consumidor \\
\hline & Colegas & Alguém que sempre está querendo algo mais \\
\hline & Alguns puxam o tapete & \\
\hline & Perdeu seu poder de fogo & \\
\hline & Muito estresse & \\
\hline & Nível de exigência muito grande & \\
\hline
\end{tabular}

\begin{tabular}{|c|c|c|}
\hline & $\begin{array}{c}\text { Ser mais cobrado } \\
\text { Ter mais concorrência } \\
\text { Trabalhar com dinheiro } \\
\text { Resolver uma necessidade } \\
\text { Dar conta do serviço } \\
\text { Trabalhar para sustento material } \\
\text { Ser colegas } \\
\text { Puxar o tapete } \\
\text { Perder poder de fogo } \\
\text { Ter muito estresse } \\
\text { Ter nível de exigência muito grande }\end{array}$ & $\begin{array}{c}\text { Ser sofisticado } \\
\text { Ser racional } \\
\text { Adquirir na medida em que precisa } \\
\text { Ser preocupado } \\
\text { Querer bom atendimento } \\
\text { Querer algo mais }\end{array}$ \\
\hline $\begin{array}{c}\text { Referências } \\
\text { Identitárias } \\
\text { Predominantes }\end{array}$ & $\begin{array}{l}\text { O que é ser } \\
\text { Bancário }\end{array}$ & O que é ser Consumidor \\
\hline
\end{tabular}

\begin{tabular}{|c|c|}
\hline Ser bancário X & Prefere ser bancário \\
Ser consumidor & Prefere ser bancário \\
\hline Ser bancário X & \\
Ser organização & \\
\hline
\end{tabular}

\section{\begin{tabular}{|l|l}
\hline Referências sociais & Organização \\
\hline
\end{tabular}}

\begin{tabular}{|c|c|c|} 
Variável Estudada & Identidade Social \\
\hline
\end{tabular}

\begin{tabular}{|c|c|c|c|c|}
\cline { 2 - 5 } \multicolumn{1}{c|}{} & Valor & Sentido & Valor & Sentido \\
\cline { 2 - 5 } & Pessoal & Contraditório & Pessoal & Positivo \\
& Econômico & Positivo & Positivo \\
Social & Negativo & Econômico & Positivo \\
\hline $\begin{array}{c}\text { Descrições feitas } \\
\text { pelos bancários }\end{array}$ & \multicolumn{2}{|c|}{ Descrição do Trabalho } & Descrição do Consumo e do Consumidor \\
\hline
\end{tabular}

Figura 40 - $\quad$ Análise dos dados do Entrevistado: 37

Fonte: Dados de pesquisa 


\begin{tabular}{|c|c|c|}
\hline & \multicolumn{2}{|c|}{ Tipificações } \\
\hline & Trabalhador & Consumidor \\
\hline \multirow[t]{2}{*}{$\mathrm{Eu}$} & Eu - trabalhador & Eu - consumidor \\
\hline & $\begin{array}{c}\text { Metas } \\
\text { Mais estressante } \\
\text { Mais informação } \\
\text { Bancário é como loja } \\
\text { Transparente } \\
\text { Me coloco no lugar do cliente } \\
\text { Sou exigente }\end{array}$ & $\begin{array}{l}\text { Sou meio chato } \\
\text { Rigoroso } \\
\text { Displicente } \\
\text { Não olho preço } \\
\text { Não sou consumista } \\
\text { Sou exigente }\end{array}$ \\
\hline \multirow[t]{2}{*}{ Outro } & Colega de trabalho & Consumidor \\
\hline & $\begin{array}{c}\text { Estabilidade } \\
\text { Vou crescer rápido } \\
\text { Tem visão de longo prazo } \\
\text { Não preciso puxar o tapete } \\
\text { Desorganizada, estressada }\end{array}$ & $\begin{array}{c}\text { Identifica com credibilidade } \\
\text { Com a marca } \\
\text { Confia nas pessoas }\end{array}$ \\
\hline
\end{tabular}

\begin{tabular}{|c|c|c|}
\hline & $\begin{array}{c}\text { Ter metas } \\
\text { Estar mais estressado } \\
\text { Lidar com mais informação } \\
\text { Ser uma loja } \\
\text { Ser transparente } \\
\text { Colocar-se no lugar do cliente } \\
\text { Ser exigente } \\
\text { Ser estável } \\
\text { Crescer rápido } \\
\text { Ter visão de longo prazo } \\
\text { Não precisar puxar o tapete } \\
\text { Ser desorganizado }\end{array}$ & $\begin{array}{c}\text { Ser chato } \\
\text { Ser rigoroso } \\
\text { Ser displicente } \\
\text { Não olhar preço } \\
\text { Não ser consumista } \\
\text { Ser exigente } \\
\text { Identificar com credibilidade } \\
\text { Identificar com a marca } \\
\text { Confiar nas pessoas }\end{array}$ \\
\hline $\begin{array}{c}\text { Referências } \\
\text { Identitárias } \\
\text { Predominantes }\end{array}$ & $\begin{array}{l}\text { O que é ser } \\
\text { Bancário }\end{array}$ & O que é ser Consumidor \\
\hline
\end{tabular}

\begin{tabular}{|c|c|} 
Ser bancário X & Prefere ser consumidor \\
Ser consumidor & Prefere ser da organização \\
\hline Ser bancário X & \\
Ser organização & \\
\hline
\end{tabular}

Referências sociais $\quad$ Organização

Variável Estudada Identidade Social

\begin{tabular}{|c|c|c|c|c|}
\cline { 2 - 5 } \multicolumn{1}{c|}{} & Valor & Sentido & Valor & Sentido \\
\cline { 2 - 5 } & $\begin{array}{c}\text { Moral } \\
\text { Pessoal }\end{array}$ & $\begin{array}{c}\text { Positivo } \\
\text { Contraditório }\end{array}$ & $\begin{array}{c}\text { Pessoal } \\
\text { Moral } \\
\text { Econômico }\end{array}$ & $\begin{array}{c}\text { Negativo } \\
\text { Positivo }\end{array}$ \\
\hline $\begin{array}{c}\text { Descrições feitas } \\
\text { pelos bancários }\end{array}$ & \multicolumn{2}{|c|}{ Descrição do Trabalho } & Descrição do Consumo e do Consumidor \\
\hline
\end{tabular}

Figura 41 - $\quad$ Análise dos dados do Entrevistado: 38

Fonte: Dados de pesquisa 


\begin{tabular}{|c|c|c|}
\hline & \multicolumn{2}{|c|}{ Tipificações } \\
\hline & Trabalhador & Consumidor \\
\hline $\mathrm{Eu}$ & Eu - trabalhador & Eu - consumidor \\
\hline & $\begin{array}{c}\text { Sistematizado } \\
\text { Metódico } \\
\text { Lidar com dinheiro } \\
\text { Responsável } \\
\text { Procuro atender da melhor forma } \\
\text { Trata como gostaria de ser tratado }\end{array}$ & $\begin{array}{l}\text { Exigente } \\
\text { Já foi mais consumista }\end{array}$ \\
\hline Outro & Colega de trabalho & Consumidor \\
\hline & $\begin{array}{l}\text { Relações complicadas } \\
\text { Pessoas bacanas } \\
\text { Lidar com egos } \\
\text { Culturas diferentes } \\
\text { Não é uma classe unida } \\
\text { Sindicato muito fraco }\end{array}$ & É o que faz você estar ali \\
\hline
\end{tabular}

\begin{tabular}{|c|c|c|}
\hline & $\begin{array}{c}\text { Ser sistematizado } \\
\text { Ser metódico } \\
\text { Lidar com dinheiro } \\
\text { Ser responsável } \\
\text { Atender da melhor forma } \\
\text { Tratar como gostaria de ser tratado } \\
\text { Ter relações complicadas } \\
\text { Ser bacana } \\
\text { Lidar com egos } \\
\text { Lidar com culturas diferentes } \\
\text { Não ser unido }\end{array}$ & $\begin{array}{c}\text { Ser exigente } \\
\text { Ser consumista } \\
\text { Ser o motivo de alguém estar ali }\end{array}$ \\
\hline $\begin{array}{c}\text { Referências } \\
\text { Identitárias } \\
\text { Predominantes }\end{array}$ & $\begin{array}{c}\text { O que é ser } \\
\text { Bancário }\end{array}$ & O que é ser Consumidor \\
\hline
\end{tabular}

\begin{tabular}{|c|c|}
\hline Ser bancário X & Prefere ser bancário \\
Ser consumidor & Prefere ser da organização \\
\hline Ser bancário X & \\
Ser organização & \\
\hline
\end{tabular}

Variável Estudada
Identidade Social

\begin{tabular}{|c|c|c|c|c|}
\hline & Valor & Sentido & Valor & Sentido \\
\hline & $\begin{array}{c}\text { Social } \\
\text { Econômico } \\
\text { Pessoal } \\
\text { Moral }\end{array}$ & $\begin{array}{l}\text { Negativo } \\
\text { Positivo } \\
\text { Positivo } \\
\text { Positivo }\end{array}$ & $\begin{array}{c}\text { Pessoal } \\
\text { Econômico }\end{array}$ & $\begin{array}{l}\text { Positivo } \\
\text { Positivo }\end{array}$ \\
\hline $\begin{array}{c}\text { Descrições feitas } \\
\text { pelos bancários }\end{array}$ & \multicolumn{2}{|c|}{ Descrição do Trabalho } & \multicolumn{2}{|c|}{ Descrição do Consumo e do Consumidor } \\
\hline
\end{tabular}

Figura 42 - $\quad$ Análise dos dados do Entrevistado: 39

Fonte: Dados de pesquisa 


\begin{tabular}{|c|c|c|}
\hline & \multicolumn{2}{|c|}{ Tipificações } \\
\hline & Trabalhador & Consumidor \\
\hline \multirow[t]{2}{*}{$\mathrm{Eu}$} & Eu - trabalhador & Eu - consumidor \\
\hline & $\begin{array}{c}\text { Profissão mais popular } \\
\text { Prestar serviços para a sociedade } \\
\text { Atendimento ao cliente } \\
\text { Identifico-me como bancário } \\
\text { Gosto de conversar } \\
\text { Gosto de atender clientes } \\
\text { Lidar com números } \\
\text { Verificar dados de empresas }\end{array}$ & $\begin{array}{c}\text { Consome mais do que o necessário } \\
\text { Procura produtos que atenda relação custo- } \\
\text { benefício }\end{array}$ \\
\hline \multirow[t]{2}{*}{ Outro } & Colega de trabalho & Consumidor \\
\hline & $\begin{array}{l}\text { Pessoa que gosta da profissão } \\
\text { Passou no concurso } \\
\text { Comprometidas com a organização } \\
\text { Precisa estar disposto a ajudar }\end{array}$ & $\begin{array}{l}\text { Gosta da instituição } \\
\text { Demonstra confiança } \\
\text { Valoriza o empregado }\end{array}$ \\
\hline
\end{tabular}

\begin{tabular}{|c|c|c|}
\hline & $\begin{array}{c}\text { Ser mais popular } \\
\text { Prestar serviços à comunidade } \\
\text { Atender o cliente } \\
\text { Identificar como bancário } \\
\text { Gostar de conversar } \\
\text { Gostar de atender clientes } \\
\text { Lidar com números } \\
\text { Verificar dados de empresas } \\
\text { Gostar da profissão } \\
\text { Passar no concurso } \\
\text { Ser comprometida com a organização } \\
\text { Estar disposto a ajudar }\end{array}$ & $\begin{array}{c}\text { Consumir mais do que o necessário } \\
\text { Procurar produtos que atenda relação custo- } \\
\text { benefício } \\
\text { Gostar da instituição } \\
\text { Demonstrar confiança } \\
\text { Valorizar o empregado }\end{array}$ \\
\hline $\begin{array}{c}\text { Referências } \\
\text { Identitárias } \\
\text { Predominantes }\end{array}$ & $\begin{array}{l}\text { O que é ser } \\
\text { Bancário }\end{array}$ & O que é ser Consumidor \\
\hline
\end{tabular}

\begin{tabular}{|c|c|} 
Ser bancário X & Prefere ser bancário \\
Ser consumidor & Prefere ser da organização \\
\hline Ser bancário X & \\
Ser organização & \\
\hline
\end{tabular}

Referências sociais $\quad$ Organização

Variável Estudada $\quad$ Identidade Social

\begin{tabular}{|c|c|c|c|c|}
\cline { 2 - 5 } \multicolumn{1}{c|}{} & Valor & Sentido & Valor & Sentido \\
\cline { 2 - 5 } & $\begin{array}{c}\text { Pessoal } \\
\text { Econômico }\end{array}$ & $\begin{array}{c}\text { Positivo } \\
\text { Positivo } \\
\text { Pessoal }\end{array}$ & $\begin{array}{c}\text { Moral } \\
\text { Eegativo } \\
\text { Positivo }\end{array}$ \\
\hline $\begin{array}{c}\text { Descrições feitas } \\
\text { pelos bancários }\end{array}$ & \multicolumn{2}{|c|}{ Descrição do Trabalho } & Descrição do Consumo e do Consumidor \\
\hline
\end{tabular}

Figura 43 - $\quad$ Análise dos dados do Entrevistado: 40

Fonte: Dados de pesquisa 


\begin{tabular}{|c|c|c|}
\hline & \multicolumn{2}{|c|}{ Tipificações } \\
\hline & Trabalhador & Consumidor \\
\hline $\mathrm{Eu}$ & Eu - trabalhador & Eu - consumidor \\
\hline $\begin{array}{c}\text { Prefere ser } \\
\text { Bancário }\end{array}$ & $\begin{array}{c}\text { Metas } \\
\text { Fim da estabilidade } \\
\text { Prestador de serviços } \\
\text { Atendimento } \\
\text { Financeiro com emocional } \\
\text { Apaixonada } \\
\text { Procura qualidade }\end{array}$ & $\begin{array}{c}\text { Sente feliz consumindo } \\
\text { Momentos de felicidade } \\
\text { Compulsiva } \\
\text { Procura qualidade }\end{array}$ \\
\hline Outro & Colega de trabalho & Consumidor \\
\hline & $\begin{array}{c}\text { Amigo } \\
\text { Cumplicidade } \\
\text { Relativamente unida }\end{array}$ & Casquinha de ovo \\
\hline
\end{tabular}

\begin{tabular}{|c|c|c|}
\hline & $\begin{array}{c}\text { Ter metas } \\
\text { Perder a estabilidade } \\
\text { Prestar serviços } \\
\text { Atender } \\
\text { Juntar o financeiro com o emocional } \\
\text { Ser apaixonado } \\
\text { Procurar qualidade } \\
\text { Ser amigo } \\
\text { Ter cumplicidade } \\
\text { Ser relativamente unido }\end{array}$ & $\begin{array}{c}\text { Sentir feliz consumindo } \\
\text { Ter momentos de felicidade } \\
\text { Ser compulsiva } \\
\text { Procurar qualidade }\end{array}$ \\
\hline $\begin{array}{c}\text { Referências } \\
\text { Identitárias } \\
\text { Predominantes }\end{array}$ & $\begin{array}{l}\text { O que é ser } \\
\text { Bancário }\end{array}$ & O que é ser Consumidor \\
\hline
\end{tabular}

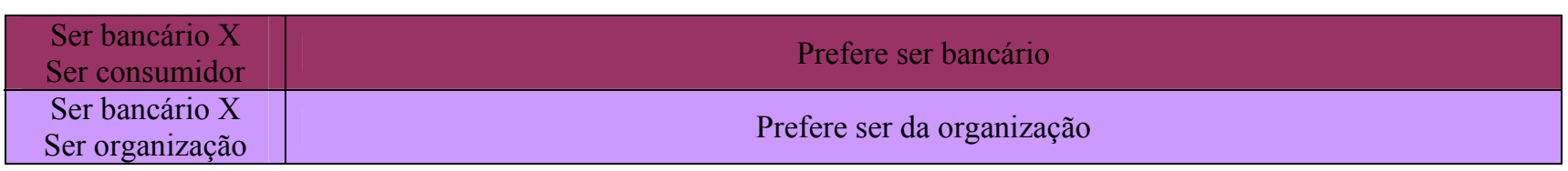

\begin{tabular}{|c|c|}
\hline Referências sociais & Família \\
\hline Variável Estudada & Identidade Social \\
\hline
\end{tabular}

\begin{tabular}{|c|c|c|c|c|}
\cline { 2 - 5 } \multicolumn{1}{c|}{} & Valor & Sentido & Valor & Sentido \\
\cline { 2 - 5 } & $\begin{array}{c}\text { Pessoal } \\
\text { Econômico } \\
\text { Moral }\end{array}$ & $\begin{array}{c}\text { Contraditório } \\
\text { Positivo } \\
\text { Positivo }\end{array}$ & $\begin{array}{c}\text { Pessoal } \\
\text { Econômico } \\
\text { Positivo }\end{array}$ & Descrição do Consumo e do Consumidor \\
\hline $\begin{array}{c}\text { Descrições feitas } \\
\text { pelos bancários }\end{array}$ & \multicolumn{2}{|c|}{ Descrição do Trabalho } & Dóno \\
\hline
\end{tabular}

Figura 44 - $\quad$ Análise dos dados do Entrevistado: 41

Fonte: Dados de pesquisa 


\begin{tabular}{|c|c|c|}
\hline & \multicolumn{2}{|c|}{ Tipificações } \\
\hline & Trabalhador & Consumidor \\
\hline \multirow{2}{*}{$\mathrm{Eu}$} & Eu - trabalhador & Eu - consumidor \\
\hline & $\begin{array}{c}\text { Paciência para conversar } \\
\text { Atendimento } \\
\text { Profissional boa } \\
\text { Venho trabalhar animada } \\
\text { Tento ajudar } \\
\text { Sabe o quanto custa o dinheiro } \\
\text { Sou diferente no banco e na minha família }\end{array}$ & $\begin{array}{l}\text { Gosto muito de comprar } \\
\text { Sabe o quanto custa o dinheiro }\end{array}$ \\
\hline \multirow[t]{2}{*}{ Outro } & Colega de trabalho & Consumidor \\
\hline & $\begin{array}{c}\text { Pessoas que vêm trabalhar e não têm vontade } \\
\text { Tem colega muito bom } \\
\text { Muita gente me ajudou }\end{array}$ & $\begin{array}{c}\text { Pessoa leiga } \\
\text { Não sabe o que o banco pode oferecer } \\
\text { Não sabe quanto custa o dinheiro }\end{array}$ \\
\hline
\end{tabular}

\begin{tabular}{|c|c|c|}
\hline & $\begin{array}{c}\text { Ter paciência para conversar } \\
\text { Atender } \\
\text { Ser bom profissional } \\
\text { Vir trabalhar animado } \\
\text { Tentar ajudar } \\
\text { Saber o quanto custa o dinheiro } \\
\text { Ser diferente no banco e na família } \\
\text { Vir trabalhar sem vontade } \\
\text { Ser bom colega } \\
\text { Ser ajudado por muita gente }\end{array}$ & $\begin{array}{l}\text { Gostar muito de comprar } \\
\text { Saber o quanto custa o dinheiro } \\
\text { Ser leigo } \\
\text { Não saber o que o banco pode oferecer } \\
\text { Não saber o quanto custa o dinheiro }\end{array}$ \\
\hline $\begin{array}{c}\text { Referências } \\
\text { Identitárias } \\
\text { Predominantes }\end{array}$ & $\begin{array}{c}\text { O que é ser } \\
\text { Bancário }\end{array}$ & O que é ser Consumidor \\
\hline
\end{tabular}

\begin{tabular}{|c|c|}
\hline $\begin{array}{l}\text { Ser bancário X } \\
\text { Ser consumidor }\end{array}$ & Prefere ser bancário \\
\hline $\begin{array}{c}\text { Ser bancário X } \\
\text { Ser organização }\end{array}$ & Depende da função a ser desempenhada \\
\hline
\end{tabular}

Referências sociais $\quad$ Curso superior em que se formou

Variável Estudada $\quad$ Identidade Social

\begin{tabular}{|c|c|c|c|c|}
\hline & Valor & Sentido & Valor & Sentido \\
\hline & $\begin{array}{c}\text { Pessoal } \\
\text { Econômico }\end{array}$ & $\begin{array}{l}\text { Positivo } \\
\text { Positivo }\end{array}$ & $\begin{array}{c}\text { Pessoal } \\
\text { Moral } \\
\text { Econômico }\end{array}$ & $\begin{array}{c}\text { Negativo } \\
\text { Negativo } \\
\text { Positivo } \\
\end{array}$ \\
\hline $\begin{array}{l}\text { Descrições feitas } \\
\text { pelos bancários }\end{array}$ & \multicolumn{2}{|c|}{ Descrição do Trabalho } & \multicolumn{2}{|c|}{ Descrição do Consumo e do Consumidor } \\
\hline
\end{tabular}

Figura 45 - $\quad$ Análise dos dados do Entrevistado: 42

Fonte: Dados de pesquisa 


\begin{tabular}{|c|c|c|}
\hline & \multicolumn{2}{|c|}{ Tipificações } \\
\hline & Trabalhador & Consumidor \\
\hline \multirow[t]{2}{*}{$\mathrm{Eu}$} & Eu - trabalhador & Eu - consumidor \\
\hline & $\begin{array}{c}\text { Conhecer o cliente } \\
\text { Interagir com o cliente } \\
\text { Procuro ir além das minhas funções } \\
\text { Gosto de atender a pessoa e ir além } \\
\text { Sou profissional }\end{array}$ & $\begin{array}{c}\text { Busco coisas que me satisfaçam } \\
\text { Sou consumidor voraz } \\
\text { Gosto de ter as coisas para atender minha } \\
\text { necessidade } \\
\text { Gosto de qualidade } \\
\text { Sou exigente }\end{array}$ \\
\hline \multirow[t]{2}{*}{ Outro } & Colega de trabalho & Consumidor \\
\hline & $\begin{array}{c}\text { Equipe bem unida } \\
\text { Um completa o serviço do outro } \\
\text { Foi em outro banco e se sentiu um lixo }\end{array}$ & $\begin{array}{l}\text { Caixinha de surpresas } \\
\text { Tem várias facetas }\end{array}$ \\
\hline
\end{tabular}

\begin{tabular}{|c|c|c|}
\hline & $\begin{array}{c}\text { Conhecer o cliente } \\
\text { Interagir com o cliente } \\
\text { Procurar ir além das funções } \\
\text { Gostar de atender a pessoa e ir além } \\
\text { Ser profissional } \\
\text { Ser equipe unida } \\
\text { Completar o serviço do outro }\end{array}$ & $\begin{array}{c}\text { Buscar coisas que me satisfaçam } \\
\text { Ser voraz } \\
\text { Gostar de ter coisas para atender necessidade } \\
\text { Gostar de qualidade } \\
\text { Ser exigente } \\
\text { Ser caixinha de surpresa } \\
\text { Ter várias facetas }\end{array}$ \\
\hline $\begin{array}{c}\text { Referências } \\
\text { Identitárias } \\
\text { Predominantes }\end{array}$ & $\begin{array}{l}\text { O que é ser } \\
\text { Bancário }\end{array}$ & O que é ser Consumidor \\
\hline
\end{tabular}

\begin{tabular}{|c|c|}
\hline Ser bancário X & Prefere ser consumidor \\
Ser consumidor & Prefere ser da organização \\
\hline Ser bancário X & \\
Ser organização & \\
\hline
\end{tabular}

\begin{tabular}{|c|c|}
\hline Referências sociais & Família \\
\hline Variável Estudada & Identidade Social \\
\hline
\end{tabular}

\begin{tabular}{|c|c|c|c|c|}
\cline { 2 - 5 } \multicolumn{1}{c|}{} & Valor & Sentido & Valor & Sentido \\
\cline { 2 - 5 } \multicolumn{1}{c|}{} & $\begin{array}{c}\text { Pessoal } \\
\text { Econômico }\end{array}$ & $\begin{array}{c}\text { Contraditório } \\
\text { Positivo }\end{array}$ & $\begin{array}{c}\text { Pessoal } \\
\text { Econômico }\end{array}$ & Positivo \\
Positivo
\end{tabular}

\section{Figura 46 - $\quad$ Análise dos dados do Entrevistado: 43}

Fonte: Dados de pesquisa 


\begin{tabular}{|c|c|c|}
\hline & \multicolumn{2}{|c|}{ Tipificações } \\
\hline & Trabalhador & Consumidor \\
\hline $\mathrm{Eu}$ & Eu - trabalhador & Eu - consumidor \\
\hline & $\begin{array}{c}\text { Menos trabalho } \\
\text { Fazer empréstimos } \\
\text { Rotina } \\
\text { Tem paciência para atender } \\
\text { Disposição para trabalhar } \\
\text { Gosto do que faço } \\
\text { Entendo as reclamações }\end{array}$ & $\begin{array}{l}\text { Não sou consumidor assídua } \\
\text { Compro o que tenho necessidade } \\
\text { Não sou compulsiva }\end{array}$ \\
\hline Outro & Colega de trabalho & Consumidor \\
\hline & $\begin{array}{c}\text { Sempre me dei bem com colegas } \\
\text { Sempre muito amigos } \\
\text { Sem muita competição } \\
\text { Bom amigo mesmo } \\
\text { Categoria não é muito valorizada } \\
\text { A sociedade não valoriza muito a profissão do } \\
\text { bancário hoje em dia. }\end{array}$ & $\begin{array}{l}\text { O cliente tem sempre razão } \\
\text { Reclama } \\
\text { Dependemos dele para existir }\end{array}$ \\
\hline
\end{tabular}

\begin{tabular}{|c|c|c|}
\hline & $\begin{array}{c}\text { Ter menos trabalho } \\
\text { Fazer empréstimos } \\
\text { Ter rotina } \\
\text { Ter paciência para atender } \\
\text { Disposição para trabalhar } \\
\text { Gostar do que faz } \\
\text { Entender reclamações } \\
\text { Dar-se bem com colegas } \\
\text { Ser muito amigo } \\
\text { Não competir } \\
\text { Não ser valorizado }\end{array}$ & $\begin{array}{c}\text { Não ser assídua } \\
\text { Comprar necessidade } \\
\text { Não ser compulsiva } \\
\text { Ter sempre razão } \\
\text { Reclamar } \\
\text { Ser fonte de dependência para alguém existir }\end{array}$ \\
\hline $\begin{array}{l}\text { Referências } \\
\text { Identitárias } \\
\text { Predominantes }\end{array}$ & $\begin{array}{l}\text { O que é ser } \\
\text { Bancário }\end{array}$ & O que é ser Consumidor \\
\hline
\end{tabular}

\begin{tabular}{|c|c|}
\hline Ser bancário X & Prefere ser bancário \\
Ser consumidor & Prefere ser da organização \\
\hline Ser bancário X & \\
Ser organização & \\
\hline
\end{tabular}

\begin{tabular}{|c|c|}
\hline Referências sociais & Família \\
\hline Variável Estudada & Identidade Social \\
\hline
\end{tabular}

\begin{tabular}{|c|c|c|c|c|}
\cline { 2 - 5 } \multicolumn{1}{c|}{} & Valor & Sentido & Valor & Sentido \\
\cline { 2 - 5 } \multicolumn{1}{c|}{} & $\begin{array}{c}\text { Pessoal } \\
\text { Econômico } \\
\text { Social }\end{array}$ & $\begin{array}{c}\text { Positivo } \\
\text { Positivo } \\
\text { Positivo }\end{array}$ & Pessoal \\
Econômico & Positivo \\
\hline $\begin{array}{c}\text { Descrições feitas } \\
\text { pelos bancários }\end{array}$ & \multicolumn{2}{|c|}{ Descrição do Trabalho } & Descrição do Consumo e do Consumidor \\
\hline
\end{tabular}

\section{Figura 47 - $\quad$ Análise dos dados do Entrevistado: 44}

Fonte: Dados de pesquisa 


\begin{tabular}{|c|c|c|}
\hline & \multicolumn{2}{|c|}{ Tipificações } \\
\hline & Trabalhador & Consumidor \\
\hline \multirow[t]{2}{*}{$\mathrm{Eu}$} & Eu - trabalhador & Eu - consumidor \\
\hline & $\begin{array}{c}\text { Exigências maiores } \\
\text { Sabe da vida das pessoas } \\
\text { Orientador do cliente } \\
\text { Procura orientar } \\
\text { Sou melhor com o cliente do que comigo } \\
\text { mesmo } \\
\text { O contato com clientes o torna consumista } \\
\text { Os clientes sempre me procuram } \\
\text { Dou o máximo de mim }\end{array}$ & $\begin{array}{l}\text { Consumidor afoito na hora de comprar } \\
\text { Não tenho paciência }\end{array}$ \\
\hline \multirow[t]{2}{*}{ Outro } & Colega de trabalho & Consumidor \\
\hline & $\begin{array}{c}\text { Equipes bastante unidas } \\
\text { Não tive problemas de relacionamento } \\
\text { Tive bastante ajuda }\end{array}$ & $\begin{array}{c}\text { Perfis diferentes } \\
\text { Pessoa que precisa mesmo daquele serviço }\end{array}$ \\
\hline
\end{tabular}

\begin{tabular}{|c|c|c|}
\hline & $\begin{array}{c}\text { Ter exigências maiores } \\
\text { Saber da vida das pessoas } \\
\text { Orientar cliente } \\
\text { Ser melhor com cliente do que consigo mesmo } \\
\text { Tornar-se mais consumista } \\
\text { Ser sempre procurado pelos clientes } \\
\text { Dar o máximo se si } \\
\text { Ser equipe unida } \\
\text { Não ter problema de relacionamento com } \\
\text { colega } \\
\text { Ter bastante ajuda }\end{array}$ & $\begin{array}{c}\text { Ser afoito na hora de comprar } \\
\text { Não ter paciência } \\
\text { Ter perfis diferentes } \\
\text { Precisar de um serviço }\end{array}$ \\
\hline $\begin{array}{c}\text { Referências } \\
\text { Identitárias } \\
\text { Predominantes } \\
\end{array}$ & $\begin{array}{l}\text { O que é ser } \\
\text { Bancário }\end{array}$ & O que é ser Consumidor \\
\hline
\end{tabular}

\begin{tabular}{|c|c|}
\hline Ser bancário X & Prefere ser consumidor \\
Ser consumidor & Prefere ser da organização \\
\hline Ser bancário X & Ser organização
\end{tabular}

\begin{tabular}{|c|c|}
\hline Referências sociais & Organização \\
\hline Variável Estudada & Identidade Social
\end{tabular}

\begin{tabular}{|c|c|c|c|c|}
\cline { 2 - 5 } \multicolumn{1}{c|}{} & Valor & Sentido & Valor & Sentido \\
\cline { 2 - 4 } \multicolumn{1}{c|}{} & $\begin{array}{c}\text { Pessoal } \\
\text { Econômico }\end{array}$ & $\begin{array}{c}\text { Contraditório } \\
\text { Positivo }\end{array}$ & $\begin{array}{c}\text { Pessoal } \\
\text { Econômico }\end{array}$ & Positivo \\
\hline $\begin{array}{c}\text { Descrições feitas } \\
\text { pelos bancários }\end{array}$ & \multicolumn{2}{|c|}{ Descrição do Trabalho } & Descrição do Consumo e do Consumidor \\
\hline
\end{tabular}

Figura 48 - $\quad$ Análise dos dados do Entrevistado: 45

Fonte: Dados de pesquisa 


\begin{tabular}{|c|c|c|}
\hline & \multicolumn{2}{|c|}{ Tipificações } \\
\hline & Trabalhador & Consumidor \\
\hline \multirow[t]{2}{*}{$\mathrm{Eu}$} & Eu - trabalhador & Eu - consumidor \\
\hline & $\begin{array}{c}\text { Ameaças de ser mandado embora } \\
\text { Boa comunicação } \\
\text { Antenado com a economia } \\
\text { Sou exigente comigo } \\
\text { Tento sempre bater as minhas metas } \\
\text { Sempre atenciosa com os clientes } \\
\text { Faço brincadeiras } \\
\text { Trato bem todos eles } \\
\text { Sempre passo visão de pessoa alegre } \\
\text { Tenho que engolir sapo } \\
\text { Planeja o trabalho }\end{array}$ & $\begin{array}{c}\text { Sou munheca } \\
\text { Não gosto de comprar } \\
\text { Compro à vista } \\
\text { Não gosto de fazer financiamento } \\
\text { Prefiro ter o dinheiro e comprar } \\
\text { Consumo é descontraído }\end{array}$ \\
\hline \multirow[t]{2}{*}{ Outro } & Colega de trabalho & Consumidor \\
\hline & $\begin{array}{l}\text { Alguns são complicados } \\
\text { Chamam a atenção } \\
\text { Acham que são superiores } \\
\text { Todo mundo é amigo } \\
\text { Bancário esta estressado }\end{array}$ & $\begin{array}{c}\text { Posso perder meu emprego por causa dos } \\
\text { clientes } \\
\text { O cliente é complicado } \\
\text { Xinga } \\
\text { Ameaça } \\
\end{array}$ \\
\hline
\end{tabular}

\begin{tabular}{|c|c|c|}
\hline & $\begin{array}{c}\text { Ser ameaçado de ser mandado embora } \\
\text { Ter boa comunicação } \\
\text { Ser antenado com a economia } \\
\text { Ser exigente consigo } \\
\text { Bater metas } \\
\text { Ser atenciosa com clientes } \\
\text { Fazer brincadeiras } \\
\text { Tratar bem a todos } \\
\text { Passar visão de pessoa alegre } \\
\text { Engolir sapo } \\
\text { Planejar o trabalho } \\
\text { Ser complicado } \\
\text { Chamar a atenção } \\
\text { Achar ser superior } \\
\text { Ser amigo } \\
\text { Estar estressado } \\
\end{array}$ & $\begin{array}{c}\text { Ser munheca } \\
\text { Não gostar de comprar } \\
\text { Comprar à vista } \\
\text { Não gostar de fazer financiamento } \\
\text { Ter dinheiro e comprar } \\
\text { Ser descontraído } \\
\text { Fazer o outro perder emprego } \\
\text { Ser complicado } \\
\text { Xingar } \\
\text { Ameaçar }\end{array}$ \\
\hline $\begin{array}{c}\text { Referências } \\
\text { Identitárias } \\
\text { Predominantes }\end{array}$ & $\begin{array}{l}\text { O que é ser } \\
\text { Bancário }\end{array}$ & O que é ser Consumidor \\
\hline
\end{tabular}

\begin{tabular}{|c|c|}
\hline Ser bancário X & Prefere ser bancário \\
Ser consumidor & Prefere ser da organização \\
\hline Ser bancário X & \\
Ser organização & \\
\hline
\end{tabular}

\begin{tabular}{|c|c|c|c|c|}
\cline { 2 - 5 } \multicolumn{1}{c|}{} & Valor & Sentido & Valor & Sentido \\
\cline { 2 - 4 } \multicolumn{1}{c|}{} & $\begin{array}{c}\text { Pessoal } \\
\text { Econômico }\end{array}$ & $\begin{array}{c}\text { Contraditório } \\
\text { Positivo }\end{array}$ & $\begin{array}{c}\text { Pessoal } \\
\text { Moral }\end{array}$ & $\begin{array}{c}\text { Positivo } \\
\text { Contraditório }\end{array}$ \\
\hline $\begin{array}{c}\text { Descrições feitas } \\
\text { pelos bancários }\end{array}$ & \multicolumn{2}{|c|}{ Descrição do Trabalho } & Descrição do Consumo e do Consumidor \\
\hline
\end{tabular}

Figura 49 - $\quad$ Análise dos dados do Entrevistado: 46

Fonte: Dados de pesquisa 


\begin{tabular}{|c|c|c|}
\hline & \multicolumn{2}{|c|}{ Tipificações } \\
\hline & Trabalhador & Consumidor \\
\hline \multirow[t]{11}{*}{$\mathrm{Eu}$} & Eu - trabalhador & Eu - consumidor \\
\hline & Mais exigente & Gastador criterioso \\
\hline & Profissão de status & Comparo preços \\
\hline & Categoria mobilizada & Reclamo \\
\hline & Elitizada & Sou questionador \\
\hline & Criterioso & \\
\hline & Sou organizado & \\
\hline & Gosto de receber & \\
\hline & Entregar serviço limpo & \\
\hline & Não gosto de falcatruas & \\
\hline & Eu tenho que ser como o consumidor & \\
\hline \multirow[t]{5}{*}{ Outro } & Colega de trabalho & Consumidor \\
\hline & O colega não é fiel & Muito difícil lidar \\
\hline & Ele é cruel & Tem uns que são super radicais \\
\hline & Só olha pro seu umbigo & Tem que tratar como gostaria de ser tratado \\
\hline & Se escondem atrás de um status & \\
\hline
\end{tabular}

\begin{tabular}{|c|c|c|}
\hline & $\begin{array}{c}\text { Ser exigente } \\
\text { Ter status } \\
\text { Ser mobilizado } \\
\text { Ser elitizado } \\
\text { Ser criterioso } \\
\text { Ser organizado } \\
\text { Gostar de receber } \\
\text { Entregar serviço limpo } \\
\text { Não gostar de falcatruas } \\
\text { Ser como o consumidor } \\
\text { Não ser fiel com colega } \\
\text { Ser cruel com colega } \\
\text { Só olhar para o umbigo } \\
\text { Se esconder atrás do status }\end{array}$ & $\begin{array}{c}\text { Gastar criteriosamente } \\
\text { Comparar preços } \\
\text { Reclamar } \\
\text { Ser questionador } \\
\text { Ser difícil de lidar } \\
\text { Ser super radical } \\
\text { Tratar como gostaria de ser tratado }\end{array}$ \\
\hline $\begin{array}{c}\text { Referências } \\
\text { Identitárias } \\
\text { Predominantes }\end{array}$ & $\begin{array}{l}\text { O que é ser } \\
\text { Bancário }\end{array}$ & O que é ser Consumidor \\
\hline
\end{tabular}

\begin{tabular}{|c|c|}
\hline Ser bancário X & Prefere ser bancário \\
Ser consumidor & Depende da função a ser desempenhada \\
\hline Ser bancário X & \\
Ser organização &
\end{tabular}

\begin{tabular}{l|l} 
Referências sociais & Organização \\
\hline
\end{tabular}

$\begin{array}{ll}\text { Variável Estudada } & \text { Identidade Social }\end{array}$

\begin{tabular}{|c|c|c|c|c|}
\cline { 2 - 5 } \multicolumn{1}{c|}{} & Valor & Sentido & Valor & Sentido \\
\cline { 2 - 5 } & $\begin{array}{c}\text { Pessoal } \\
\text { Econômico }\end{array}$ & $\begin{array}{c}\text { Positivo } \\
\text { Positivo } \\
\text { Econsoal } \\
\text { Social }\end{array}$ & $\begin{array}{c}\text { Positivo } \\
\text { Positivo }\end{array}$ \\
\hline $\begin{array}{c}\text { Descrições feitas } \\
\text { pelos bancários }\end{array}$ & \multicolumn{2}{|c|}{ Descrição do Trabalho } & Descrição do Consumo e do Consumidor \\
\hline
\end{tabular}

Figura 50 - $\quad$ Análise dos dados do Entrevistado: 47

Fonte: Dados de pesquisa 


\begin{tabular}{|c|c|c|}
\hline & \multicolumn{2}{|c|}{ Tipificações } \\
\hline & Trabalhador & Consumidor \\
\hline $\mathrm{Eu}$ & Eu - trabalhador & Eu - consumidor \\
\hline & $\begin{array}{c}\text { Menos serviços } \\
\text { Trabalha com recursos de terceiros } \\
\text { Satisfação do cliente } \\
\text { Encantar o cliente } \\
\text { Procura atender como gostaria de ser atendido }\end{array}$ & $\begin{array}{c}\text { Exigente } \\
\text { Observo a forma de atendimento } \\
\text { E me identifica com a forma de atendimento } \\
\text { Compra mais do que precisava }\end{array}$ \\
\hline Outro & Colega de trabalho & Consumidor \\
\hline & $\begin{array}{c}\text { Equipe } \\
\text { Bastante parceiros } \\
\text { Os bancários em si não são concorrentes }\end{array}$ & $\begin{array}{l}\text { Bastante diversificado } \\
\text { São mais criteriosos } \\
\text { Mais específicos } \\
\text { São exigentes }\end{array}$ \\
\hline
\end{tabular}

\begin{tabular}{|c|c|c|}
\hline & $\begin{array}{c}\text { Lidar com menos serviços } \\
\text { Trabalhar com recursos de terceiros } \\
\text { Satisfazer o cliente } \\
\text { Encantar o cliente } \\
\text { Atender como gostaria de ser atendido } \\
\text { Ser equipe } \\
\text { Ser parceiro com colegas } \\
\text { Não ser concorrente entre si }\end{array}$ & $\begin{array}{c}\text { Ser exigente } \\
\text { Observar a forma de atendimento } \\
\text { Identificar com a forma de atendimento } \\
\text { Comprar mais do que precisa } \\
\text { Ser bastante diversificado } \\
\text { Ser mais criterioso } \\
\text { Ser mais específico }\end{array}$ \\
\hline $\begin{array}{l}\text { Referências } \\
\text { Identitárias } \\
\text { Predominantes }\end{array}$ & $\begin{array}{c}\text { O que é ser } \\
\text { Bancário }\end{array}$ & O que é ser Consumidor \\
\hline
\end{tabular}

\begin{tabular}{|c|c|}
\hline $\begin{array}{l}\text { Ser bancário X } \\
\text { Ser consumidor }\end{array}$ & Prefere ser bancário \\
\hline $\begin{array}{c}\text { Ser bancário X } \\
\text { Ser organização }\end{array}$ & Prefere ser bancário \\
\hline
\end{tabular}

\begin{tabular}{|c|c|}
\hline Referências sociais & Organização \\
\hline Variável Estudada & Identidade Social \\
\hline
\end{tabular}

\begin{tabular}{|c|c|c|c|c|}
\cline { 2 - 4 } \multicolumn{1}{c|}{} & Valor & Sentido & Valor & Sentido \\
\cline { 2 - 4 } & $\begin{array}{c}\text { Pessoal } \\
\text { Econômico }\end{array}$ & $\begin{array}{c}\text { Positivo } \\
\text { Positivo }\end{array}$ & $\begin{array}{c}\text { Pessoal } \\
\text { Econômico }\end{array}$ & Positivo \\
\hline $\begin{array}{c}\text { Descrições feitivo } \\
\text { pelos bancários }\end{array}$ & \multicolumn{2}{|c|}{ Descrição do Trabalho } & Descrição do Consumo e do Consumidor \\
\hline
\end{tabular}

Figura 51 -

Análise dos dados do Entrevistado: 48

Fonte: Dados de pesquisa 


\begin{tabular}{|c|c|c|}
\hline & \multicolumn{2}{|c|}{ Tipificações } \\
\hline & Trabalhador & Consumidor \\
\hline $\mathrm{Eu}$ & Eu - trabalhador & Eu - consumidor \\
\hline & $\begin{array}{l}\text { Menos mecanicista } \\
\text { Vende dinheiro } \\
\text { Sou paternalista }\end{array}$ & $\begin{array}{c}\text { Não sou consumista } \\
\text { Tenho controle financeiro } \\
\text { Só consumo em extrema necessidade, mesmo } \\
\text { gostando de consumir }\end{array}$ \\
\hline Outro & Colega de trabalho & Consumidor \\
\hline & $\begin{array}{c}\text { Importante } \\
\text { Tem que estar ajudando o outro sempre } \\
\text { É competitividade, tem que estar mordendo o } \\
\text { cliente ali }\end{array}$ & $\begin{array}{c}\text { Pessoa que está precisando de mim } \\
\text { Poupador, } \\
\text { Investidor } \\
\text { Tomador } \\
\end{array}$ \\
\hline
\end{tabular}

\begin{tabular}{|c|c|c|}
\hline & $\begin{array}{c}\text { Ser mais mecanicista } \\
\text { Vender dinheiro } \\
\text { Ser paternalista } \\
\text { Ser importante } \\
\text { Estar ajudando o outro sempre } \\
\text { Ser competitivo } \\
\text { Morder o cliente }\end{array}$ & $\begin{array}{c}\text { Não ser consumista } \\
\text { Ter controle financeiro } \\
\text { Consumir em extrema necessidade } \\
\text { Gostar de consumir } \\
\text { Precisar de alguém } \\
\text { Poupar } \\
\text { Investir } \\
\text { Tomar }\end{array}$ \\
\hline $\begin{array}{c}\text { Referências } \\
\text { Identitárias } \\
\text { Predominantes }\end{array}$ & $\begin{array}{c}\text { O que é ser } \\
\text { Bancário }\end{array}$ & O que é ser Consumidor \\
\hline
\end{tabular}

\begin{tabular}{|c|c|}
\hline Ser bancário X & Prefere ser consumidor \\
Ser consumidor & Prefere ser da organização \\
\hline Ser bancário X & \\
Ser organização & \\
\hline
\end{tabular}

\begin{tabular}{|c|c|}
\hline Referências sociais & Organização \\
\hline Variável Estudada & Identidade Social \\
\hline
\end{tabular}

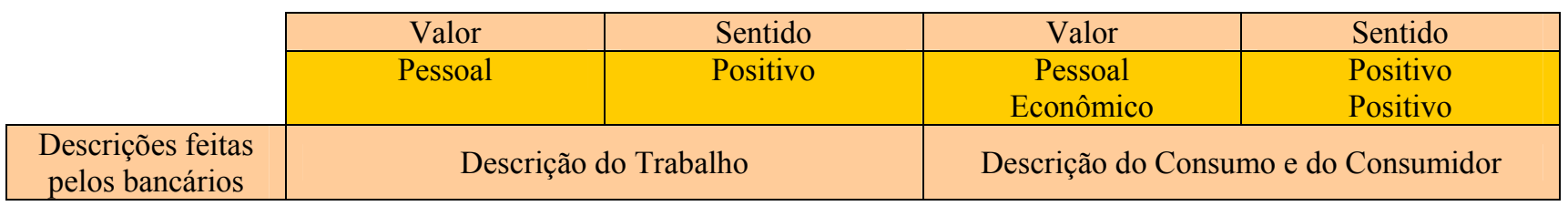

Figura 52 - $\quad$ Análise dos dados do Entrevistado: 49

Fonte: Dados de pesquisa 


\begin{tabular}{|c|c|c|}
\cline { 2 - 3 } \multicolumn{1}{c|}{} & \multicolumn{2}{c|}{ Tipificações } \\
\cline { 2 - 3 } & Trabalhador & Consumidor \\
\hline Eu & Eu - trabalhador & Eu - consumidor \\
& Pressão & Pesquiso muito \\
& Mais agressivo no chão \\
& Relacionamento com o cliente & Não gasto \\
& Lidar com dinheiro & \\
\hline Sutro honesto & Colega de trabalho & Consumidor \\
\hline & Limitações & Nosso principal ativo \\
& Cliente é exigente \\
& São privilegiados em questão de salários & O mais importante da instituição \\
\hline
\end{tabular}

\begin{tabular}{|c|c|c|}
\hline & $\begin{array}{c}\text { Estar sob pressão } \\
\text { Ser mais agressivo } \\
\text { Relacionar com o cliente } \\
\text { Lidar com dinheiro } \\
\text { Ser honesto } \\
\text { Ter limitações } \\
\text { Ser privilegiado } \\
\end{array}$ & $\begin{array}{c}\text { Pesquisar muito } \\
\text { Ser pé no chão } \\
\text { Não gastar } \\
\text { Ser principal ativo } \\
\text { Ser exigente } \\
\text { Ser o mais importante da instituição }\end{array}$ \\
\hline $\begin{array}{c}\text { Referências } \\
\text { Identitárias } \\
\text { Predominantes }\end{array}$ & $\begin{array}{l}\text { O que é ser } \\
\text { Bancário }\end{array}$ & O que é ser Consumidor \\
\hline
\end{tabular}

\begin{tabular}{|c|c|}
\hline Ser bancário X & Prefere ser bancário \\
Ser consumidor & Prefere ser da organização \\
\hline Ser bancário X & Ser organização
\end{tabular}

Variável Estudada $\quad$ Identidade Social

\begin{tabular}{|c|c|c|c|c|}
\cline { 2 - 5 } \multicolumn{1}{c|}{} & Valor & Sentido & Valor & Sentido \\
\cline { 2 - 5 } & $\begin{array}{c}\text { Econômico } \\
\text { Pessoal } \\
\text { Moral }\end{array}$ & $\begin{array}{c}\text { Positivo } \\
\text { Contraditório } \\
\text { Positivo }\end{array}$ & $\begin{array}{c}\text { Pessoal } \\
\text { Moral } \\
\text { Econômico }\end{array}$ & $\begin{array}{c}\text { Negativo } \\
\text { Positivo }\end{array}$ \\
\hline $\begin{array}{c}\text { Descrições feitas } \\
\text { pelos bancários }\end{array}$ & \multicolumn{2}{c|}{ Descrição do Trabalho } & Descrição do Consumo e do Consumidor \\
\hline
\end{tabular}

Figura 53 - $\quad$ Análise dos dados do Entrevistado: 50

Fonte: Dados de pesquisa 
APÊNDICE D - QUADROS-SÍNTESE DOS DADOS COLETADOS 
Quadro 14 - Quadro resumo das características demográficas dos entrevistados

\begin{tabular}{|c|c|c|c|c|c|c|}
\hline Entrevistado & Gênero & Idade & $\begin{array}{c}\text { Natureza Econômica } \\
\text { do Banco }\end{array}$ & Formação & Estado Civil & $\begin{array}{l}\text { Número de } \\
\text { Filhos }\end{array}$ \\
\hline Entrevistado 01 & $\mathrm{~F}$ & 28 & Privado & Superior Completo & Casado & 0 \\
\hline Entrevistado 02 & $\mathrm{M}$ & 26 & Privado & Cursando Superior & Solteiro & 0 \\
\hline Entrevistado 03 & $\mathrm{M}$ & 30 & Privado & Especialização & Solteiro & 0 \\
\hline Entrevistado 04 & $\mathrm{M}$ & 30 & Privado & Superior Completo & Casado & 0 \\
\hline Entrevistado 05 & $\mathrm{M}$ & 28 & Privado & Especialização & Solteiro & 0 \\
\hline Entrevistado 06 & $\mathrm{~F}$ & 30 & Privado & Superior Completo & Solteiro & 0 \\
\hline Entrevistado 07 & $\mathrm{M}$ & 35 & Privado & Especialização & Solteiro & 0 \\
\hline Entrevistado 08 & $\mathrm{M}$ & 31 & Privado & Superior Completo & Solteiro & 0 \\
\hline Entrevistado 09 & $\mathrm{~F}$ & 36 & Privado & Cursando Superior & Casado & 1 \\
\hline Entrevistado 10 & $\mathrm{M}$ & 32 & Privado & Superior Incompleto & Casado & 2 \\
\hline Entrevistado 11 & $\mathrm{~F}$ & 40 & Privado & Superior Completo & Solteiro & 0 \\
\hline Entrevistado 12 & $\mathrm{M}$ & 45 & Privado & Superior Completo & Casado & 1 \\
\hline Entrevistado 13 & $\mathrm{~F}$ & 23 & Privado & Superior Completo & Solteiro & 0 \\
\hline Entrevistado 14 & $\mathrm{M}$ & 41 & Público & Superior Completo & Casado & 2 \\
\hline Entrevistado 15 & $\mathrm{~F}$ & 27 & Público & Superior Completo & Casado & 0 \\
\hline Entrevistado 16 & $\mathrm{M}$ & 41 & Privado & Cursando Superior & Casado & 2 \\
\hline Entrevistado 17 & $\mathrm{~F}$ & 22 & Privado & Cursando Superior & Solteiro & 0 \\
\hline Entrevistado 18 & $\mathrm{~F}$ & 26 & Privado & Cursando Superior & Solteiro & 0 \\
\hline Entrevistado 19 & $\mathrm{M}$ & 21 & Privado & Cursando Superior & Solteiro & 0 \\
\hline Entrevistado 20 & $\mathrm{M}$ & 29 & Privado & Especialização & Solteiro & 0 \\
\hline Entrevistado 21 & $\mathrm{M}$ & 47 & Privado & Superior Incompleto & Casado & 2 \\
\hline Entrevistado 22 & $\mathrm{M}$ & 35 & Privado & Superior Incompleto & Casado & 2 \\
\hline Entrevistado 23 & $\mathrm{~F}$ & 45 & Público & Superior Completo & Casado & 3 \\
\hline Entrevistado 24 & $\mathrm{~F}$ & 47 & Público & Superior Completo & Casado & 3 \\
\hline Entrevistado 25 & $\mathrm{M}$ & 50 & Público & Superior Completo & Casado & 3 \\
\hline
\end{tabular}

Fonte: dados da pesquisa 
Quadro 14 - Quadro resumo das características demográficas dos entrevistados (Continuação... )

\begin{tabular}{|c|c|c|c|c|c|c|}
\hline Entrevistado & Gênero & Idade & $\begin{array}{c}\text { Natureza Econômica } \\
\text { do Banco }\end{array}$ & Formação & Estado Civil & $\begin{array}{l}\text { Número de } \\
\text { Filhos }\end{array}$ \\
\hline Entrevistado 26 & $\mathrm{M}$ & 44 & Privado & Superior Completo & Divorciado & 0 \\
\hline Entrevistado 27 & $\mathrm{M}$ & 46 & Público & Especialização & Casado & 3 \\
\hline Entrevistado 28 & $\mathrm{M}$ & 29 & Privado & Superior Completo & Casado & 1 \\
\hline Entrevistado 29 & $\mathrm{~F}$ & 24 & Privado & Superior Completo & Solteiro & 0 \\
\hline Entrevistado 30 & $\mathrm{M}$ & 44 & Público & Superior Completo & Casado & 1 \\
\hline Entrevistado 31 & $\mathrm{M}$ & 41 & Público & Especialização & Casado & 2 \\
\hline Entrevistado 32 & $\mathrm{~F}$ & 41 & Público & Superior Completo & Divorciado & 2 \\
\hline Entrevistado 33 & $F$ & 40 & Público & Especialização & Casado & 3 \\
\hline Entrevistado 34 & $\mathrm{M}$ & 51 & Público & Especialização & Viúvo & 5 \\
\hline Entrevistado 35 & $\mathrm{M}$ & 43 & Público & Superior Completo & Casado & 2 \\
\hline Entrevistado 36 & $\mathrm{~F}$ & 29 & Privado & Segundo Grau Completo & Casado & 1 \\
\hline Entrevistado 37 & $\mathrm{M}$ & 43 & Público & Superior Completo & Casado & 1 \\
\hline Entrevistado 38 & $\mathrm{M}$ & 40 & Público & Superior Completo & Casado & 2 \\
\hline Entrevistado 39 & $\mathrm{M}$ & 25 & Privado & Superior Completo & Solteiro & 0 \\
\hline Entrevistado 40 & $\mathrm{M}$ & 28 & Público & Superior Completo & Casado & 1 \\
\hline Entrevistado 41 & $\bar{F}$ & 35 & Público & Superior incompleto & Casado & 3 \\
\hline Entrevistado 42 & $\mathrm{~F}$ & 30 & Público & Superior Completo & Casado & 1 \\
\hline Entrevistado 43 & $\mathrm{~F}$ & 43 & Público & Superior Completo & Casado & 1 \\
\hline Entrevistado 44 & $\mathrm{~F}$ & 28 & Público & Superior Completo & Solteiro & 0 \\
\hline Entrevistado 45 & $\mathrm{M}$ & 28 & Público & Superior Completo & Solteiro & 0 \\
\hline Entrevistado 46 & $\mathrm{~F}$ & 28 & Privado & Superior Completo & Casado & 0 \\
\hline Entrevistado 47 & $\mathrm{M}$ & 40 & Privado & Superior Completo & Casado & 1 \\
\hline Entrevistado 48 & $\mathrm{M}$ & 37 & Privado & Cursando Superior & Casado & 2 \\
\hline Entrevistado 49 & $\mathrm{~F}$ & 24 & Privado & Especialização & Solteiro & 0 \\
\hline Entrevistado 50 & $\mathrm{M}$ & 33 & Privado & Especialização & Casado & 2 \\
\hline
\end{tabular}

Fonte: dados da pesquisa 
Quadro 15 - Quadro resumo das características funcionais dos entrevistados

\begin{tabular}{|c|c|c|c|c|c|c|}
\hline Entrevistado & $\begin{array}{c}\text { Tempo no } \\
\text { banco }\end{array}$ & $\begin{array}{l}\text { Tempo de } \\
\text { Agência }^{1}\end{array}$ & $\begin{array}{l}\text { Trabalhou em } \\
\text { outros bancos }\end{array}$ & $\begin{array}{c}\text { Tempo total } \\
\text { como bancário }\end{array}$ & Nível hierárquico do cargo & $\begin{array}{c}\text { Tempo no cargo } \\
\text { atual }^{1}\end{array}$ \\
\hline Entrevistado 01 & 6 & 6 & Não & 6 & Gerente Intermediário & 3 \\
\hline Entrevistado 02 & 1,33 & 1,33 & Sim & 11 & Gerente Intermediário & 1,33 \\
\hline Entrevistado 03 & 0,33 & 0,33 & Sim & 8 & Gerente Intermediário & 0,33 \\
\hline Entrevistado 04 & 2,66 & 2,66 & Não & 2,66 & Gerente Intermediário & 2,66 \\
\hline Entrevistado 05 & 7 & 2,16 & Não & 7 & Gerente Intermediário & 1,25 \\
\hline Entrevistado 06 & 11 & 6 & Não & 11 & Gerente Intermediário & 5 \\
\hline Entrevistado 07 & 2 & 2 & Sim & 9 & Gerente Intermediário & 2 \\
\hline Entrevistado 08 & 6 & 0,1 & Sim & 13 & Gerente Intermediário & 0,1 \\
\hline Entrevistado 09 & 2 & 0,5 & Sim & 2,5 & Gerente Intermediário & 1,5 \\
\hline Entrevistado 10 & 2 & 2 & Sim & 17 & Gerente Intermediário & 2 \\
\hline Entrevistado 11 & 20 & 4 & Não & 20 & Gerente Intermediário & 0,83 \\
\hline Entrevistado 12 & 2,5 & 2,5 & Sim & 26 & Gerente da Agência & 2,5 \\
\hline Entrevistado 13 & 3 & 3 & Não & 3 & Operacional & 2,5 \\
\hline Entrevistado 14 & 15 & 2 & Sim & 22 & Gerente da Agência & 5 \\
\hline Entrevistado 15 & 3 & 1 & Não & 3 & Operacional & 3 \\
\hline Entrevistado 16 & 2,33 & 2,33 & Sim & 24 & Gerente Intermediário & 2,33 \\
\hline Entrevistado 17 & 2,5 & 2,5 & Não & 2,5 & Operacional & 1 \\
\hline Entrevistado 18 & 4 & 4 & Não & 4 & Operacional & 3 \\
\hline Entrevistado 19 & 1,5 & 1,5 & Não & 1,5 & Operacional & 1 \\
\hline Entrevistado 20 & 7 & 7 & Não & 7 & Gerente Intermediário & 1,5 \\
\hline Entrevistado 21 & 28 & 0,1 & Não & 28 & Gerente Intermediário & 10 \\
\hline Entrevistado 22 & 12 & 1,5 & Não & 12 & Gerente Intermediário & 2,5 \\
\hline Entrevistado 23 & 22 & 22 & Não & 22 & Gerente Intermediário & 4 \\
\hline Entrevistado 24 & 20 & 20 & Sim & 29 & Operacional & 2 \\
\hline Entrevistado 25 & 20 & 17 & Sim & 27 & Gerente Intermediário & 7 \\
\hline
\end{tabular}

Fonte: dados da pesquisa

Nota: 1 - tempo em anos 
Quadro 15 - Quadro resumo das características funcionais dos entrevistados (Continuação...)

\begin{tabular}{|c|c|c|c|c|c|c|}
\hline Entrevistado & $\begin{array}{c}\text { Tempo no } \\
\text { banco }{ }^{1}\end{array}$ & $\begin{array}{l}\text { Tempo de } \\
\text { Agência }^{1}\end{array}$ & $\begin{array}{l}\text { Trabalhou em } \\
\text { outros bancos }\end{array}$ & $\begin{array}{c}\text { Tempo total } \\
\text { como bancário } 1\end{array}$ & Nível hierárquico do cargo & $\begin{array}{c}\text { Tempo no cargo } \\
\text { atual }^{1}\end{array}$ \\
\hline Entrevistado 26 & 10 & 1 & Sim & 18 & Gerente Intermediário & 1 \\
\hline Entrevistado 27 & 18 & 1 & Não & 18 & Gerente Intermediário & 2,5 \\
\hline Entrevistado 28 & 1,25 & 1,25 & Não & 1,25 & Operacional & 1,25 \\
\hline Entrevistado 29 & 5 & 5 & Não & 5 & Operacional & 3 \\
\hline Entrevistado 30 & 18 & 2 & Sim & 24 & Operacional & 18 \\
\hline Entrevistado 31 & 17 & 2,5 & Não & 18 & Gerente Intermediário & 7 \\
\hline Entrevistado 32 & 17 & 1,66 & Não & 17 & Gerente Intermediário & 5 \\
\hline Entrevistado 33 & 4 & 2,16 & Sim & 12 & Operacional & 2,16 \\
\hline Entrevistado 34 & 0,66 & 0,33 & Não & 0,66 & Operacional & 0,5 \\
\hline Entrevistado 35 & 17 & 2,16 & Sim & 17 & Gerente da Agência & 2,16 \\
\hline Entrevistado 36 & 3,5 & 3,5 & Sim & 9 & Gerente Intermediário & 3,5 \\
\hline Entrevistado 37 & 23 & 2,16 & Não & 23 & Gerente Intermediário & 11 \\
\hline Entrevistado 38 & 18 & 0,66 & Não & 18 & Gerente da Agência & 7 \\
\hline Entrevistado 39 & 2 & 0,5 & Sim & 5 & Operacional & 3 \\
\hline Entrevistado 40 & 2 & 2 & Não & 2 & Operacional & 2 \\
\hline Entrevistado 41 & 6,5 & 2 & Sim & 13 & Operacional & 2 \\
\hline Entrevistado 42 & 0,5 & 0,16 & Não & 0,5 & Operacional & 0,5 \\
\hline Entrevistado 43 & 18 & 2,5 & Não & 18 & Operacional & 2,5 \\
\hline Entrevistado 44 & 6,5 & 6,5 & Não & 6,5 & Operacional & 1,5 \\
\hline Entrevistado 45 & 7,16 & 1,1 & Não & 7,16 & Gerente Intermediário & 0,16 \\
\hline Entrevistado 46 & 2 & 2 & Não & 2 & Operacional & 2 \\
\hline Entrevistado 47 & 15 & 0,5 & Sim & 17,5 & Gerente Intermediário & 0,5 \\
\hline Entrevistado 48 & 14 & 3,5 & Não & 14 & Gerente Intermediário & 11 \\
\hline Entrevistado 49 & 4 & 4 & Não & 4 & Gerente Intermediário & 0,33 \\
\hline Entrevistado 50 & 1,5 & 1,5 & Sim & 11 & Gerente Intermediário & 1,5 \\
\hline
\end{tabular}

Fonte: dados da pesquisa

Nota: 1 - tempo em anos 


\section{ÍNDICE REMISSIVO DAS FALAS DOS ENTREVISTADOS}

(Entrevistado 01) $106,109,130,137,143$

(Entrevistado 02) $100,110,122,132,133$

(Entrevistado 03) $106,112,127,132$

(Entrevistado 04) $110,111,123,133,141$

(Entrevistado 05) $97,101,102,105,107,110,122,140$

(Entrevistado 06) 104,108

(Entrevistado 07) $102,103,104,107,123,132,139$

(Entrevistado 08) $104,109,113,119,121,134,135,139,142,143$

(Entrevistado 09) 138

(Entrevistado 10) 101,102

(Entrevistado 11) 97

(Entrevistado 12) $108,127,134,137,140$

(Entrevistado 13) $106,138,140$

(Entrevistado 14) $101,104,105,138$

(Entrevistado 15) ...95, 100, 101, 102, 103, 106, 109, 111, 112, 122, 131, 140, 147, 148, 149, $150,151,152$

(Entrevistado 16) $96,99,120$

(Entrevistado 17) $102,110,120$

(Entrevistado 18) 110 
(Entrevistado 19) 95

(Entrevistado 20) $95,100,104,110,113,115$

(Entrevistado 21) 97

(Entrevistado 22) $108,110,137,142$

(Entrevistado 23) $96,113,141$

(Entrevistado 24) $100,108,139,141$

(Entrevistado 25) $95,123,135$

(Entrevistado 26) $99,113,115,120,139,141$

(Entrevistado 27) $99,108,112,127,139,141$

(Entrevistado 28) $104,106,115,122,144$

(Entrevistado 29) 122

(Entrevistado 30) $96,106,110,113$

(Entrevistado 31) $108,112,142,143$

(Entrevistado 32) $.102,106$

(Entrevistado 33) $102,123,141$

(Entrevistado 34) $107,114,135,137,139,142$

(Entrevistado 35) 139

(Entrevistado 36) 124,138

(Entrevistado 37) $96,135,139,144$

(Entrevistado 38) 113 


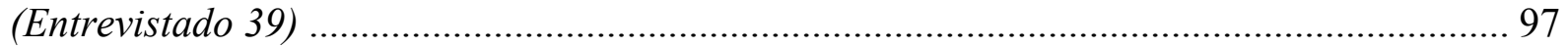

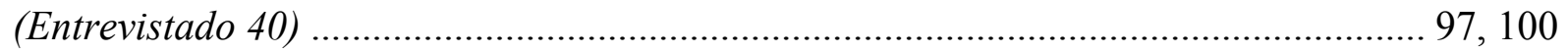

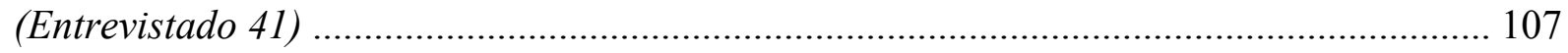

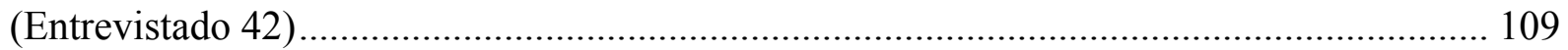

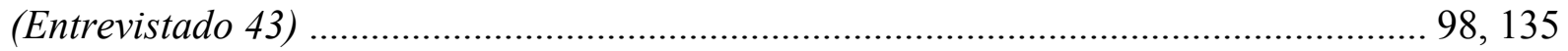

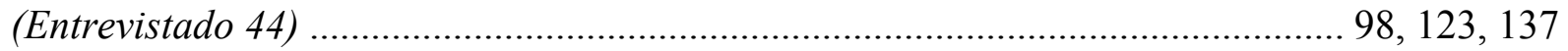

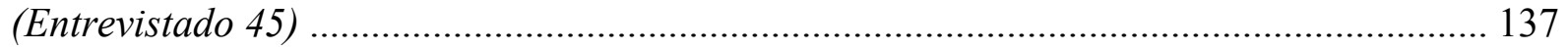

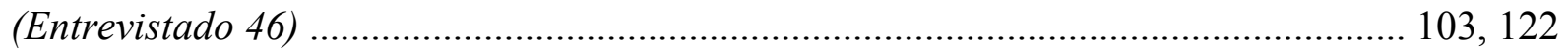

(Entrevistado 47) ........................................................................... 95, 111, 127, 131

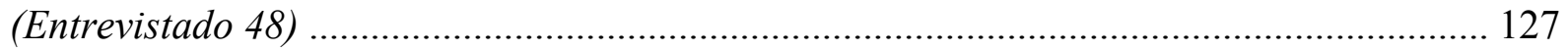

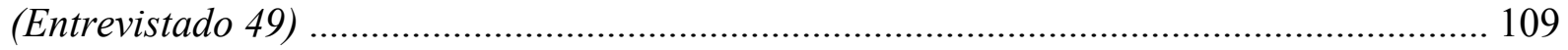

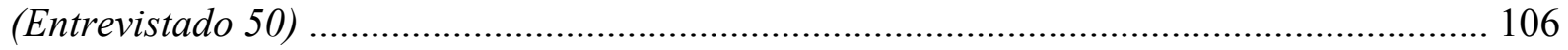

